\title{
Bibliography on Biomass Feedstock Research: 1978-2002
}

\author{
J. H. Cushman \\ L. S. Cooper \\ P. C. Anderson
}

Environmental Sciences Division

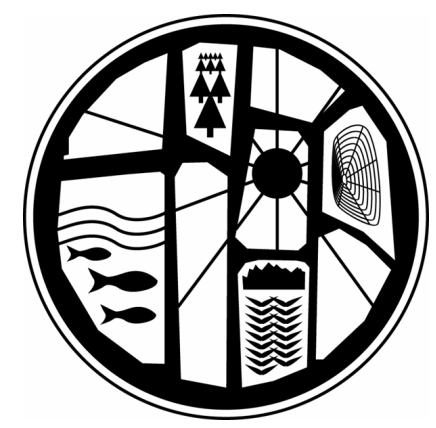




\section{DOCUMENT AVAILABILITY}

Reports produced after January 1,1996, are generally available free via the U.S. Department of Energy (DOE) Information Bridge.

Web site http://www.osti.gov/bridge

Reports produced before January 1, 1996, may be purchased by members of the public from the following source.

National Technical Information Service

5285 Port Royal Road

Springfield, VA 22161

Telephone 703-605-6000 (1-800-553-6847)

TDD 703-487-4639

Fax 703-605-6900

E-mail info@ntis.fedworld.gov

Web site http://www.ntis.gov/support/ordernowabout.htm

Reports are available to DOE employees, DOE contractors, Energy Technology Data Exchange (ETDE) representatives, and International Nuclear Information System (INIS) representatives from the following source.

Office of Scientific and Technical Information

P.O. Box 62

Oak Ridge, TN 37831

Telephone 865-576-8401

Fax 865-576-5728

E-mail reports@adonis.osti.gov

Web site http://www.osti.gov/contact.html

This report was prepared as an account of work sponsored by an agency of the United States Government. Neither the United States Government nor any agency thereof, nor any of their employees, makes any warranty, express or implied, or assumes any legal liability or responsibility for the accuracy, completeness, or usefulness of any information, apparatus, product, or process disclosed, or represents that its use would not infringe privately owned rights. Reference herein to any specific commercial product, process, or service by trade name, trademark, manufacturer, or otherwise, does not necessarily constitute or imply its endorsement, recommendation, or favoring by the United States Government or any agency thereof. The views and opinions of authors expressed herein do not necessarily state or reflect those of the United States Government or any agency thereof. 
Environmental Sciences Division

BIBLIOGRAPHY ON BIOMASS FEEDSTOCK RESEARCH: 1978-2002

\author{
J. H. Cushman \\ L. S. Cooper \\ P. C. Anderson ${ }^{1}$ \\ Environmental Sciences Division \\ Oak Ridge National Laboratory
}

Date Published: April 2003

Prepared for

U.S. Department of Energy

Office of Biomass

Budget Activity Nos. EB 5203000 and EB 2404000

Prepared by

OAK RIDGE NATIONAL LABORATORY

Oak Ridge, Tennessee 37831

managed by

UT-BATTELLE, LLC

for the

U.S. DEPARTMENT OF ENERGY

under contract DE-AC05-00OR22725

${ }^{1}$ Spallation Neutron Source Project 



\section{CONTENTS}

ABSTRACT





\begin{abstract}
This report provides bibliographic citations for more than 1400 reports on biomass feedstock development published by Oak Ridge National Laboratory and its collaborators from 1978 through 2002. Oak Ridge National Laboratory is engaged in analysis of biomass resource supplies, research on the sustainability of feedstock resources, and research on feedstock engineering and infrastructure. From 1978 until 2002, Oak Ridge National Laboratory also provided technical leadership for the U.S. Department of Energy's Bioenergy Feedstock Development Program (BFDP), which supported research to identify and develop promising energy crops. This bibliography lists reports published by Oak Ridge National Laboratory and by its collaborators in the BFDP, including graduate student theses and dissertations.
\end{abstract}





\section{INTRODUCTION}

This report provides bibliographic citations for more than 1400 reports on biomass feedstock development published by Oak Ridge National Laboratory and its collaborators from 1978 through 2002. Oak Ridge National Laboratory supports the U.S. Department of Energy's Biomass Program by developing information, tools, and technology to support the production of sustainable and economically viable biomass resources. Current efforts address integrated economic and resource analysis, research on the sustainability of feedstock resources, and research on feedstock engineering and infrastructure. From 1978 until 2002, Oak Ridge National Laboratory also provided technical leadership for the U.S. Department of Energy's Bioenergy Feedstock Development Program (BFDP). This program supported research on woody and herbaceous energy crops, including species screening studies; crop management and environmental research; crop development for selected model species; integrated resource and economic analysis; and, scale-up, feasibility, and demonstration projects.

This document covers all research supported by the BFDP. It includes journal articles, proceedings papers, books or book chapters, and other publications. Citations are listed alphabetically by author and date, and are numbered for use with keyword and author indexes. Graduate student theses and dissertations resulting from BFDP-sponsored research are included in a separate listing.

More than 40 universities, U.S. Department of Agriculture research units, and industries participated in the BFDP. The citations in the bibliography were compiled from the progress reports of individual research projects. Many of the projects also received significant support from other public and private sources. In cost-shared projects it can be difficult to determine sponsorship for any individual component. The compilers of this bibliography acknowledge that much of the work would not have been possible without the support of other organizations, and apologize for any citations included inappropriately.

Most of the journal articles, books, and conference proceedings are available through libraries or the publishers listed in the citations. Reports published by Oak Ridge National Laboratory are available through the National Technical Information Service. Reports produced after January 1, 1996, are generally available free via the U.S. Department of Energy Information Bridge website http://www.osti.gov/bridge. Reports produced before January 1, 1996, may be purchased from the National Technical Information Service at the address shown on the inside cover of this report. 



\section{CITATIONS}

1. Abrahamson, L. P., R. C. McKittrick, E. H. White, R. F. Kopp, and C. A. Nowak. 1992. Successful no-till hybrid poplar establishment in New York. The Forestry Chronicle 68:218.

Keywords: no-till/ New York/ cultural practices/ weed control/ poplars, hybrid/ herbicides/ erosion

2. Abrahamson, L. P., D. J. Robison, and E. H. White. 1988. Site preparation, weed control and herbicide use in fast-growing hardwood plantations. pp. 17-53. In Proceedings: Forestry Herbicides in the Northwest. M. C. Vodak (ed.). Rutgers University.

Keywords: site preparation/ weeds/ herbicides/ hardwoods

3. Abrahamson, L. P., T. A. Volk, R. F. Kopp, E. H. White, and J. L. Ballard. 2002. Willow Biomass Producer's Handbook. New York State Energy Research and Development Authority, Albany, New York.

Keywords: willows/ bioenergy

4. Abrahamson, L. P., E. H. White, C. A. Nowak, R. D. Briggs, and J. R. Robison. 1990. Evaluating hybrid poplar clonal growth potential in a three-year-old genetic selection field trial. Biomass 21:101-114. Keywords: poplars, hybrid/ genetic modification/ clonal propagation/ hardwoods/ poplars/ Septorial Cryptosphareia/ intensive culture/ multivariate analysis/ diseases/glyphosate/ buffer strips/ insects

5. Adegbidi, H. G., T. A. Volk, E. H. White, L. P. Abrahamson, R. D. Briggs, and D. H. Bickelhaupt. 2001. Biomass and nutrient removal by willow clones in experimental bioenergy plantations in $\mathrm{New}$ York State. Biomass \& Bioenergy 20:399411.

Keywords: Salix/ short-rotation intensive culture/ nutrient use efficiency/ macronutrients/ harvest cycles/ planting density/ willows

6. Ager, A., P. E. Heilman, and R. F. Stettler. 1993. Genetic variation in red alder (Alnus rubra) in relation to native climate and geography. Canadian Journal of Forest Research 23:1930-1939.

Keywords: genetic variations/ alders/ Alnus rubra

7. Ager, A., N. E. Nordh, S. Ledin, M. E. Ostry, M. Carlson, and A. RonnbergWastljung. 1990. International transfer of Alnus, Populus, and Salix. Biomass 22:4962.

Keywords: biomass crops/ alders/ poplars/ willows/ agroforestry/ tree improvement/ genetic modification

8. Akinyemiju, O. A., and D. I. Dickmann. 1982. Contrasting effects of simazine on the photosynthetic physiology and leaf morphology of two Populus clones. Physiologia Plantarum 55:402-406.

Keywords: herbicides/ photosynthesis/ Populus/ morphology/ physiology

9. Akinyemiju, O. A., and D. I.

Dickmann. 1982. The Influence of Tillage and the Herbicides Simazine and Diuron on Establishing Poplar Clones in Lower Michigan. National Resource Research Report 426. Michigan State University, Agricultural Experiment Station, East Lansing, Michigan.

Keywords: herbicides/ poplars/ cultural practices

10. Akinyemiju, O. A., J. G. Isebrands, N. D. Nelson, and D. I. Dickmann. 1982. Use of glyphosate in the establishment of Populus in short rotation intensive culture. pp. 94-102. In Proceedings, 1982 North American Poplar Council Meeting. J. Zavitkovski and E. A. Hansen (eds.). Kansas State University, Manhattan, Kansas. 
Keywords: herbicides/ Populus/ short rotation intensive culture

11. Alexandrova, K. S., P. D. Denchev, and B. V. Conger. 1996. Cell biology \& molecular genetics, in vitro development of inflorescences from switchgrass nodal segments. Crop Science 36:175-178. Keywords: molecular genetics/ switchgrass/ Panicum virgatum/ tissue culture

12. Alexandrova, K. S., P. D. Denchev, and B. V. Conger. 1996. In vitro development of inflorescences from switchgrass nodal segments. Crop Science 36(1):175-178.

Keywords: in vitro culture/ inflorescences/ switchgrass/ Panicum virgatum/ nodes

13. Alexandrova, K. S., P. D. Denchev, and B. V. Conger. 1996.

Micropropagation of switchgrass by node culture. Crop Science 36:1709-1711.

Keywords: micropropagation/ switchgrass/ Panicum virgatum/ nodes/genotypes

14. Alstrom-Rapaport, C., M. Lascoux, Y. C. Wang, G. T. Roberts, and G. A. Tuskan. 1998. Identification of a RAPD marker linked to sex determination in the basket willow (Salix viminalis L.). Journal of Heredity 89:44-49.

Keywords: RAPD markers/ willows/ Salix viminalis/ trees, dioecious/gender/ genetics

15., anders, R., R. L. Graham, B. Hektor, and C. Rakos. 1999. Critical factors to bioenergy implementation. Biomass and Bioenergy 17:113-126.

Keywords: nontechnical barriers/ policy

\section{6., anderson, I. C., D. R. Buxton, and} J. A. Hallam. 1994. Selection of Herbaceous Energy Crops for the Western Corn Belt: Final Report Part I: Agronomic Aspects for the Period March 1, 1988 to November 30, 1993. ORNL/Sub/88SC264/P1. Oak Ridge National Laboratory, Oak Ridge, Tennessee.

Keywords: energy crops, herbaceous/ biomass crops/ species selection
17., anderson, I. C., D. R. Buxton, and J. A. Hallam. 1994. Selection of Herbaceous Energy Crops for the Western Corn Belt: Final Report Part II: Economic Potentials 1988 to 1993 . ORNL/Sub/88SC264/P2. Oak Ridge National Laboratory, Oak Ridge, Tennessee.

Keywords: energy crops, herbaceous/ economics/ species selection

18. Argent, R. M. 1984. Outside storage effects on fuel potential of wood chip piles. Transactions of the Kansas Academy of Science 3:1.

Keywords: storage/ fuel properties/ wood

19. Ariyadasa, K. P., and D. J. Frederick. 1987. Aboveground Biomass Estimation for Seven Tree Species Growing on the Coastal Plain of Georgia. North Carolina State University, Raleigh, North Carolina. Keywords: pines/ pines/ sycamores/ Platanus occidentalis/ willows/ Quercus phellos/ sweetgum/ Liquidambar styraciflual ash, green/ Fraxinus pennsylvanica/ Eucalyptus macarthurii/ Eucalyptus viminal

20. Arrillaga, I., and S. A. Merkle. 1993. Regenerating plants from in vitro culture of black locust cotyledon and leaf explants. HortScience 28(9):942-945.

Keywords: Robinia pseudoacacia/ tissue culture/ light/ organogenesis/ in vitro culture/ locusts, black/ cotyledon/ leaf explants

21. Arvanitis, L. G., and M. Newton. 1980. Estimation of Acreage by Ownership and Land Use/Soil Potential Categories for Selected Tree Species. University of Florida, Gainesville, Florida. Keywords: land/ soil properties/ Florida

22. Ashby, W. C., D. F. Bresnan, C. A. Huetteman, J. E. Preece, and P. L. Roth. 1991. Chilling and bud break in silver maple. Journal of Environmental Horticulture 9:4.

Keywords: Acer saccharinum/ clonal 
propagation/ harvesting/ provenance trials/ tissue culture/ bud break

23. Ashby, W. C., D. F. Bresnan, R. K. Kjelgren, P. L. Roth, J. E. Preece, and C. A. Huetteman. 1993. Coppice growth and water relations of silver maple. Biomass and Bioenergy 5:317-323.

Keywords: biofuels/ feedstocks/ foliage/ leaves/ nutrient cycling/ provenance trials/ rootstock/ sprouting/ stomata/ short rotation woody crops/ coppice/ water relations

24. Ashby, W. C., D. F. Bresnan, P. L. Roth, J. E. Preece, and C. A. Huetteman. 1992. Nursery establishment, phenology and growth of silver maple related to provenance. Biomass and Bioenergy 3:1-7. Keywords: nursery, forest/ phenology/ maples, silver/ provenance trials/ Acer saccharinum/ biofuels/ biomass crops/ bud break/ growth

25. Assefa, S., C. M. Taliaferro, M. P. Anderson, B. G. de los Reyes, and R. M. Edwards. 1999. Diversity among Cynodon accessions and taxa based on DNA amplification fingerprinting. Genome 42(3):465-474.

Keywords: Cynodon/ diversity/ DNA

26. Auld, D. L., K. A. Mahler, B. L. Bettis, and J. C. Crock. 1987.

Registration of 'Bridger' rapeseed. Crop Science 27:1310.

Keywords: rapeseed

27. Auld, D. L., K. A. Mahler, J. C. Crock, and B. L. Bettis. 1987.

Registration of 'Cascade' rapeseed. Crop Science 27:1309-1310.

Keywords: rapeseed

28. Auld, D. L., K. A. Mahler, and D. J. LeTourneau. 1989. Evaluation of four Brassica germplasm collections for fatty acid composition. Journal of the American Oil Chemists' Society 66:1475-1479.

Keywords: Brassica/ germplasm/ fatty acid composition
29. Auld, D. L., K. A. Mahler, C. L. Peterson, R. A. Korus, and P. L. Raymer. 1991. The Potential of Biodiesel Derived from Winter Rapeseed as an Alternative Source of Liquid Fuel. University of Idaho, Colleges of Agriculture and Engineering, Moscow, Idaho.

Keywords: fuels, biodiesel/ rapeseed/ fuels, liquid

30. Auld, D. L., K. A. Mahler, D. C. Thrill, D. A. Erickson, P. L. Raymer, D. C. Bridges, and J. L. Butler. 1991. Registration of 'Rebel' rapeseed. Crop Science 31:485-486.

Keywords: rapeseed

31. Auld, D. L., K. A. Mahler, D. C. Thrill, D. A. Erickson, P. L. Raymer, and J. L. Sernyk. 1991. Registration of two rapeseed germplasm populations. Crop Science 31:493-494.

Keywords: rapeseed/ germplasm

32. Auld, D. L., K. A. Mahler, and A. A. Voorhis. 1988. Evaluation of USDA Collection of Oilseed Brassicas for Fatty Acid Composition and Glucosinolate Content. Miscellanous Series Bulletin No. 114. University of Idaho, Agriculture Experiment Station, Moscow, Idaho.

Keywords: Brassica/ fatty acid composition/ glucosinolate

33. Baertsche, S. R., M. T. Yokoyama, and J. W. Hanover. 1986. Short Rotation, Hardwood Tree Biomass as Potential Feed:

1. Chemical Composition of Selected

Species. 2. Nylon Bag Ruminal Digestibility of Selected Species. 3. Ensiling

Characteristics of Selected Species.

Research Report No. 473. Michigan State

University Agricultural Experiment Station, East Lansing, Michigan.

Keywords: hardwoods/ livestock

34. Baertsche, S. R., M. T. Yokoyama, and J. W. Hanover. 1986. Short rotation, hardwood tree biomass as potential feed: Chemical composition, nylon bag ruminal degradation and ensilement of selected 
species. Journal of Animal Science

63:2028-2043.

Keywords: hardwoods/ livestock

35. Barnett, P. E., and D. L. Sivois. 1985. Roll splitting as an alternative intermediate process for wood fuel. Forest Energy Newsletter

Keywords: short rotation woody crops/ storage

36. Barron, W. F., R. D. Perlack, P. Kroll, J. H. Cushman, and J. W. Ranney. 1983. FIRSTCUT: A Preliminary Assessment Model for Short-Rotation Intensive Silviculture-Model Description and User's Guide. ORNL/TM-8566. Oak Ridge National Laboratory, Oak Ridge, Tennessee.

Keywords: short rotation woody crops/ intensive culture/ models

37. Bartfield, B. J., J. F. Clarke, O. J. Loewer, and M. Collins. 1991.

Identification and assessment of critical issues relative to modeling biomass energy production, a response to potential climate change. In Proceedings, Global Biomass Workshop. E. E. Yoder (ed.). University of Kentucky, Lexington, Kentucky.

Keywords: biomass resources/ biomass, global/ models/ climate

38. Bartholic, J. F., J. W. Hanover, L. Tombaugh, K. W. Downey, M. C. Hawley, and H. Koenig. 1983. Integrated approach for utilization of bioresources for fuels, chemicals, and traditional uses. pp. 529-565. In Wood and Agricultural Residues. E. J. Soltes (ed.). Academic Press, Inc., New York.

Keywords: plantations/ yields/ biomass resources/ agroforestry/ breeding/genetics/ clonal propagation/ nutrition/ growth/ seedlings/ pests/ pyrolysis/ gasification

39. Benjamin, W. H. 1994. Biomass storing solar energy. The New York Forest Owner 4.

Keywords: biomass crops/ carbon dioxide/ greenhouse gases/ willows
40. Berguson, W. E., and D. F. Grigal. 1985. Clonal screening of Populus and Salix for short rotation forestry on peatlands. Agronomy Abstracts pp. 215-216.

Keywords: poplars/ Salix/ clonal selection/ short rotation woody crops

41. Berguson, W. E. , E. A. Hansen, W. C. Johnson, C. B. Borse, and D. Zimmerman. 1990. Short-rotationintensive-culture tree production in Minnesota. pp. 275-294. In Proceedings, Energy from Biomass and Wastes XIII. D. L. Klass (ed.). Institute of Gas Technology, Chicago, Illinois. Keywords: short rotation intensive culture/ establishment/ poplars, hybrid/ Salix/ willows/ growth/ yields

42. Betters, D. R., L. L. Wright, and L. Couto. 1991. Short rotation woody crop plantations in Brazil and the United States. Biomass and Bioenergy 1:305-316.

Keywords: short rotation woody crops/ Brazil/ economics/ fiber/ fuels/ commercialization

43. Beyea, J., and K. H. Keeler. 1991. Biotechnological advances in biomass energy and chemical production: Impacts on wildlife and habitat. pp. 305-319. In Critical Reviews in Biotechnology. Keywords: biofuels/ environmental effects/ wastes

44. Bhat, M. G., B. C. English, and M. A. Ojo. 1992. Regional costs of transporting biomass feedstocks. pp. 50-57. In Proceedings of an Alternative Energy Conference: Liquid Fuels from Renewable Resources. J. S. Cundiff (ed.). American Society of Agricultural Engineers, St. Joseph, Michigan.

Keywords: economics/ transportation/ biomass crops/ feedstocks/ crops, lignocellulosic/ renewable energy/ biofuels/ regional analysis

45. Bhat, M. G., B. C. English, A. F. Turhollow, and H. O. Nyangito. 1994. Energy in Synthetic Fertilizers and 
Pesticides: Revisited. ORNL/Sub/9099732/2. Oak Ridge National Laboratory, Oak Ridge, Tennessee.

Keywords: fertilization/ pesticides/ economics

46. Bingaman, B. R., and E. R. Hart. 1993. Clonal and leaf age variation in Populus phenolic glycosides: Implications for host selection by Chrysomela scripta (Coleoptera: Chrysomelidae).

Environmental Entomology 22:397-403.

Keywords: Chrysomela scripta/ phenolic glycosides/ poplars

47. Birchem, R., H. E. Sommer, and C. L. Brown. 1981. Scanning electron microscopy of shoot and root development in sweetgum callus tissue culture. Forest Science 27:206-212.

Keywords: shoots/ roots/ sweetgum/ callus/ stomata/ Liquidambar styraciflua/ tissue culture/ leaf development/ roots

48. Blake, T. J., J. S. Sperry, T. J. Tschaplinski, and S. S. Wang. 1996. Water relations. pp. 401-422. In Biology of Populus and its Implications for Management and Conservation. R. F. Stettler, Jr., H. D. Bradshaw, P. E. Heilman, and T. M. Hinckley (eds.). NRC Research Press, Ottawa, Canada.

Keywords: water relations/ Populus/ poplars

49. Blake, T. J., and T. J. Tschaplinski. 1992. Water relations. pp. 66-94. In Ecophysiology of Short Rotation Forest Crops. C. P. Mitchell, J. B. FordRobertson, T. M. Hinckley, and L. Sennerby-Forsse (eds.). Elsevier Science Publishers Ltd., New York.

Keywords: water relations/ growth/ short rotation woody crops

50. Blankenhorn, P. R., T. W. Bowersox, J. J. Hillebrand, and W. K. Murphey. 1978. Evaluation Procedure for Consideration of Forest Biomass as a Fuel Source for a 100 Megawatt Electric Generating Facility. Penn State University
Bulletin 820. Pennsylvania State University, College of Agriculture, University Park, Pennsylvania.

Keywords: forests/ combustion/ conversion technologies/gasification/ power generation

51. Blankenhorn, P. R., T. W. Bowersox, K. M. Kuklewski, and G. L. Stimely. 1985. Comparison of selected fuel and chemical content values for seven Populus hybrid clones. Wood and Fiber Science 17:148-158.

Keywords: poplars, hybrid/ conversion technologies/ extractives/ holocellulose/ cellulose/ lignin/ ash content

52. Blankenhorn, P. R., T. W. Bowersox, K. M. Kuklewski, and G. L. Stimely. 1985. Effects of rotation, site, and clone on the chemical composition of Populus hybrids. Wood and Fiber Science 17:351360.

Keywords: poplars/ site characteristics/ clonal propagation/ rotation length/ composition, chemical

53. Blankenhorn, P. R., T. W. Bowersox, and W. K. Murphey. 1978. Recoverable energy from the forests, an energy balance sheet. TAPPI 61: 57-60.

Keywords: biomass crops/ energy balance/ crop management/ forests/ combustion

54. Blankenhorn, P. R., T. W. Bowersox, C. H. Strauss, G. L. Stimely, C. A. Hornicsar, and M. L. DiCola. 1984. The characterization of hybrid poplar as a potential feedstock for fermentation to ethanol. pp. 43-49. In Proceedings, 1984 TAPPI Research and Development Conference. TAPPI Press, Atlanta, Georgia. Keywords: poplars, hybrid/ quality/ ethanol

55. Blankenhorn, P. R., T. W. Bowersox, C. H. Strauss, G. L. Stimely, L. R. Stover, and M. L. DiCola. 1988. Effects of management strategy and site on selected properties of first rotation Populus hybrid NE-388. Wood and Fiber Science 20:74-81. Keywords: Populus/ crop management/ site characteristics 
56. Blankenhorn, P. R., T. W. Bowersox, C. H. Strauss, L. R. Stover, S. C. Grado, G. L. Stimely, M. L. DiCola, C. A. Hornicsar, and B. E. Lord. 1986. Net Financial and Energy Analyses for Producing Populus Hybrid Under Four Management Strategies: First Rotation. ORNL/Sub/79-07928/1. Oak Ridge National Laboratory, Oak Ridge, Tennessee. Keywords: poplars/ economics/ crop management

57. Blankenhorn, P. R., T. W. Bowersox, and R. E. Weyers. 1982. Energy relationships for selected cultural investments. Forest Science 28:459-469. Keywords: biomass crops/ crop management

58. Blankenhorn, P. R., and R. E. Weyers. 1980. Moisture effects on an energy balance developed for using forest biomass as a fuel. Forest Products Journal 30:41-46.

Keywords: energy balance/ forests/ fuels/ moisture content

59. Bloese, P., J. W. Hanover, and B. C. Bongarten. 1993. Inheritance of juvenile traits and predicted gains from selection in black locust progeny tests in Michigan and Georgia. pp. 97-107. In Genetics and Breeding.

Keywords: locusts, black/ progeny tests

60. Bongarten, B. C. 1993. The itinerant tree. The World \& I 11:202-207.

Keywords: locusts, black/ soils/ Robinia pseudoacacia

61. Bongarten, B. C., D. A. Huber, and D. K. Apsley. 1992. Environmental and genetic influences on short-rotation biomass production of black locust (Robinia pseudoacacia L.) in the Georgia Piedmont. Forestry Ecology and Management 55:315331.

Keywords: environmental effects/ genetic modification/ short rotation woody crops/ locusts, black/ soils
62. Bongarten, B. C., and S. A. Merkle. 1994. Optimizing Energy Yields in Black Locust through Genetic Selection. Final Report. ORNL/Sub/86-95907/4. Oak Ridge National Laboratory, Oak Ridge, Tennessee. Keywords: energy/ locusts, black/ genetics

63. Bowersox, T. W., P. R. Blankenhorn, and W. K. Murphey. 1979. Heat of combustion, ash content, nutrient content, and chemical content of selected Populus hybrids. Wood Science 11:257-262.

Keywords: combustion/ ash content/ nutrients/ composition, chemical/ poplars, hybrid/ harvesting

64. Bowersox, T. W., P. R. Blankenhorn, and C. H. Strauss. 1988. Second rotation growth and yield of a Populus hybrid. pp. 66-73. In Proceedings of the International Energy Agency Task II Meeting and Workshops on Cell Culture and Coppicing. A. Ferm (ed.). Finnish Forest Research Institute, Oulu, Finland.

Keywords: rotation length/ poplars, hybrid/ short rotation woody crops/ hardwoods

65. Bowersox, T. W. , P. R. Blankenhorn, C. H. Strauss, and L. R. Stover. 1982.

Growth and yield advantages of fertilizers and/or irrigation in dense Populus plantations. pp. 393-399. In Proceedings, Seventh North American Forest Biology Workshop: Physiology and Genetics of Intensive Culture. University of Kentucky, Lexington, Kentucky.

Keywords: Populus/ composition, chemical/ rotation length/ morphology/ plant age/ genetic modification/ fertilization/ irrigation

66. Bowersox, T. W. , T. H. Schubert, R. F. Strand, and C. D. Whitesell. 1990. Coppicing success of young Eucalyptus saligna in Hawaii. Biomass 23:137-148. Keywords: coppice/ seedlings/ intensive culture/ beetles, ambrosia/ Eucalyptus saligna

67. Braatne, J. H., S. B. Rood, and P. E. Heilman. 1996. Life history, ecology, and 
conservation of riparian cottonwoods in North America. pp. 57-86. In Biology of Populus and its Implications for Management and Conservation. R. F. Stettler, Jr., H. D. Bradshaw, P. E. Heilman, and T. M. Hinckley (eds.). NRC Research Press, Ottawa, Canada.

Keywords: ecology/ conservation/ cottonwoods/ Populus

68. Bradshaw, Jr., H. D. 1996. Molecular genetics of Populus. pp. 183-199. In Biology of Populus and Its Implications for Management and Conservation. R. F. Stettler, Jr., H. D. Bradshaw, P. E. Heilman, and T. M. Hinckley (eds.). NRC Research Press, Ottawa, Ontario, Canada. Keywords: molecular genetics/ Populus/ DNA

69. Bradshaw, Jr., H. D. 1997. Case history in genetics of long-lived plants: Molecular approaches to domestication of a fast-growing forest tree: Populus. pp. 219228. In Molecular Dissection of Complex Traits. A. H. Paterson (ed.). CRC Press, New York.

Keywords: genetics/ molecular genetics/ forests/ Populus/ poplars, hybrid/ quantitative trait loci (QTL)

70. Bradshaw, Jr., H. D. 1998. Case history in genetics of long-lived plants: Molecular approaches to domestication of a fast-growing forest tree: Populus. pp. 219228. In Molecular Dissection of Complex Traits. A. H. Paterson (ed.). CRC Press, New York.

Keywords: genetics/ Populus

71. Bradshaw, Jr., H. D. 1998. Molecular approaches to domestication of a fastgrowing forest tree: Populus. pp. 219-228. In Molecular analysis of complex traits. A. H. Paterson (ed.). CRC Press, Boca Raton, Florida.

Keywords: forests/ molecular genetics/ Populus

72. Bradshaw, Jr., H. D., and G. S. Foster. 1992. Marker-aided selection and propagation systems in trees: Advantages of cloning for studying quantitative inheritance. Canadian Journal of Forest Research 22:1044-1049.

Keywords: clonal propagation/ genetic modification

73. Bradshaw, Jr., H. D., and D. Grattapaglia. 1994. QTL mapping in interspecific hybrids of forest trees. Forest Genetics 1:191-196.

Keywords: quantitative trait loci (QTL)/ hybrids/ forests

74. Bradshaw, Jr., H. D., J. B. Hollick, T. J. Parsons, H. R. G. Clarke, and M. P. Gordon. 1989. Systemically woundresponsive genes in poplar trees encode proteins similar to sweet potato sporamins and legume Kunitz trypsin inhibitors. Plant Molecular Biology 14:51-59.

Keywords: DNA/ clonal propagation/ poplars/ proteinase inhibitors/ woundresponsive

75. Bradshaw, Jr., H. D., T. J. Parsons, and M. P. Gordon. 1991. Woundresponsive gene expression in poplars. Forest Ecology and Management 43:211224.

Keywords: wound-responsive/ genes/ poplars/ pathogens/ insects

76. Bradshaw, Jr., H. D., and R. F. Stettler. 1993. Molecular genetics of growth and development in Populus. I. Triploidy in hybrid poplars. Theoretical and Applied Genetics 86:301-307.

Keywords: molecular genetics/ growth/ triploidy/ poplars, hybrid/ DNA

77. Bradshaw, Jr., H. D., and R. F. Stettler. 1994. Molecular genetics of growth and development in Populus. II. Segregation distortion due to genetic load. Theoritical and Applied Genetics 89:551-558.

Keywords: molecular genetics/ growth/ poplars/ segregation distortion/ Populus trichocarpa 
78. Bradshaw, Jr., H. D., and R. F. Stettler. 1995. Molecular genetics of growth and development in Populus. IV. Mapping QTLs with large effects on growth, form, and phenology traits in a forest tree. Genetics 139:963-973.

Keywords: molecular genetics/ poplars/ phenology/growth patterns/ branch

79. Bradshaw, Jr., H. D., M. Villar, B. D. Watson, K. G. Otto, S. Stewart, and R. F. Stettler. 1994. Molecular genetics of growth and development in Populus III. a genetic linkage map of a hybrid poplar composed of RFLP, and RAPD markers. Theoretical and Applied Genetics 89:167178.

Keywords: cottonwoods/ Tacamahaca/ Aigeiros/ Salix/ genetics

80. Bransby, D. I., S. B. McLaughlin, and D. J. Parrish. 1998. A review of carbon and nitrogen balances in switchgrass grown for energy. Biomass and Bioenergy 14(4):379-384.

Keywords: energy crops, herbaceous/ Panicum virgatum/ carbon sequestration/ nitrogen

81. Bransby, D. I., and S. E. Sladden. 1995. The need and potential to further raise switchgrass yields based on 10 years of research in Alabama. pp. 261-266. In Proceedings of the Second Biomass Conference of the Americas. National Renewable Energy Laboratory, Golden, Colorado.

Keywords: switchgrass/ Panicum virgatum/ yields/ Alabama/ biomass crops

82. Bransby, D. I., S. E. Sladden, and M. E. Downing. 1996. Yield effects on bale density and time required for commercialization harvesting and baling of switchgrass. pp. 9-13. In Bioenergy '96, Partnerships to Develop and Apply Biomass Technologies.

Keywords: energy crops, herbaceous/ Panicum virgatum/ feedstocks/ harvesting
83. Bransby, D. I., S. E. Sladden, and

D. D. Kee. 1990. Selection and

Improvement of Herbaceous Energy Crops for the Southeastern USA. ORNL/Sub/85-

27409/5. Oak Ridge National Laboratory,

Oak Ridge, Tennessee.

Keywords: species selection/ crop management/ grasses/ switchgrass/ Panicum virgatum/ energy crops, herbaceous/

johnsongrass/ Sericea lespedezal napiergrass/ energy cane

84. Bransby, D. I., C. Y. Ward, C. C. King, Jr., and G. Sims. 1988. Herbaceous crops show promise as energy producers of the future. Highlights of Agricultural Research 35:16.

Keywords: energy crops, herbaceous

85. Bransby, D. I., C. Y. Ward, P. A. Rose, S. E. Sladden, and D. D. Kee. 1989. Biomass production from selected herbaceous species in the southeastern USA. Biomass 20:187-197.

Keywords: composition/ economics/ dry matter/ energy crops, herbaceous

86. Brejda, J. J., L. E. Moser, and K. P. Vogel. 1998. Evaluation of switchgrass rhizosphere microflora for enhancing yield and nutrient uptake. Agronomy Journal 90:753-758.

Keywords: switchgrass/ Panicum virgatum

87. Bresnan, D. F., W. C. Ashby, J. E. Preece, P. L. Roth, and C. A. Huetteman. 1988. Geographic variation in silver maple. Illinois State Academy of Science 81:31.

Keywords: Acer/ maples, silver/ regional analysis

88. Bridgewater, F. E., J. T. Talbert, and D. L. Rockwood. 1982. Field design for genetic testing. pp. 28-39. In Proceedings, Workshop on Progeny Testing. Southern Cooperative Series Bull. No. 275.

University of Florida, Gainesville, Florida. Keywords: experimental design/ genetics

89. Brown, C. L., and H. E. Sommer. 1982. Vegetative propagation of 
dicotyledonous trees. pp. 109-149. In Tissue Culture in Forestry. J. M. Bonga and D. J. Durzan (eds.). Martinus Nijhoff Publishers, The Netherlands.

Keywords: trees, dicotyledonous/ Salix/ poplars/ roots/ clonal propagation/ Platanus occidentalis/ economics/ tissue culture/ callus

90. Brummer, E. C. 1998. Diversity, stability, and sustainable American agriculture. Agronomy Journal 90(1):1-2. Keywords: diversity/ agriculture

91. Brummer, E. C. 1999. Capturing heterosis in forage crop cultivar development. Crop Science 39(4):943-954. Keywords: heterosis/ forage crops

92. Brummer, E. C., C. L. Burras, M. Duffy, K. J. Moore, M. E. Downing, and S. B. McLaughlin. 1997. Integration of technical aspects of switchgrass production in Iowa. pp. 1445-1454. In Third Biomass Conference of the Americas: Energy, Environment, Agriculture, and Industry. Elsevier.

Keywords: switchgrass/ Panicum virgatum/ bioenergy/ biomass crops/ soil properties/ plant breeding

93. Brunner, A. M., R. Mohamed, R. Meilan, L. A. Sheppard, W. H. Rottmann, and S. H. Strauss. 1998. Genetic engineering of sexual sterility in shade trees. Journal of Arboricult. 24(5):263-273.

Keywords: genetic modification/ sterility, sexual

94. Brunner, A. M., W. H. Rottmann, L. A. Sheppard, K. V. Krutovskii, S. P. DiFazio, S. Leonardi, and S. H. Strauss. 2000. Structure and expression of duplicate AGAMOUS orthologs in poplar. Plant Molecular Biology 44(5):

Keywords: poplars

95. Bryant, J. P., F. S. Chapin III, and D. R. Klein. 1983. Carbon/nutrient balance of boreal plants in relation to vertebrate herbivory. Oikos 40:357-368.

Keywords: nutrients/ pests/ pests

96. Bryant, J. P., G. Wieland, P. B. Reichardt, V. E. Lewis, and M. C. McCathy. 1983. Pinosylvin methyl ether deters snowshoe hare feeding on green alder. Science 222:1023-1025.

Keywords: mammals/ alders/ pests

97. Bucciarelli, B. , H. G. Jung, M. E. Ostry, N. A. Anderson, and C. P. Vance. 1998. Wound response characteristics as related to phenylpropanoid enzyme activity and lignin deposition in resistant and susceptible Populus tremuloides inoculated with Entoleuca mammata (Hypoxylon mammatum). Canadian Journal of Botany 76(7):1282-1289.

Keywords: enzymes/ lignin/ Populus tremuloides/ Entoleuca mammata

98. Bucciarelli, B. , M. E. Ostry, R. G. Fulcher, N. A. Anderson, and C. P. Vance. 1999. Histochemical and microspectrophotometric analyses of early wound responses of resistant and susceptible Populus tremuloides inoculated with Entoleuca mammata (Hypoxylon mammatum). Canadian Journal of Botany 77(4):548-555.

Keywords: histochemical/ microspectrophotometric/ Populus/ tremuloids/ Entoleuca mammata

99. Buck, M. G. 1986. Concepts of resource sharing in agroforestry systems. Agroforestry Systems 4:191-203.

Keywords: agroforestry/ woody crops/ crop management/ competition/ growth/ growth responses/ biomass crops/ Pinus radiata/ Pinus elliottii/ Leucaena/ intercropping/ coppice/ morphology/ roots/ water stress

100. Burk, T. E., N. D. Nelson, and J. G. Isebrands. 1983. Crown architecture of short-rotation, intensively cultured Populus: III. A model of first-order branch architecture. Canadian Journal of Forest Research 13:1107-1116.

Keywords: rotation length/ intensive 
culture/ poplars/ clonal propagation/ branch/ short rotation intensive culture/ stand density/ plantations/ leaf area/ branch

\section{Burkot, T. R., and D. M. Benjamin.} 1979. The biology and ecology of the cottonwood leaf beetle, Chrysomela scripta, on tissue cultured hybrid Aigeiros (Populus $\times$ Euramericana) subclones in Wisconsin. Canadian Entomology 111:551-556. Keywords: pests/ Chrysomela scriptal Populus/ Populus Euramericana

\section{Cable, T. T., T. D. Warner, and}

W. A. Geyer. 1986. Fuelwood consumption in Kansas. National Woodlands pp. 15-17.

Keywords: fuelwood/ Kansas

103. Calvin, M. 1985. Renewable fuels for the future. pp. 14. In Alternative Sources of Energy for Agriculture. J. BayPetersen (ed.). Food \& Fertilizer Technical Center, Taiwan, Republic of China.

Keywords: renewable energy

104. Calvin, M. 1986. Fuel oils from Euphorbs and other higher plants. pp. 21. In Proceedings: International Symposium on Chemistry, Taxonomy, and Economic Botany of Euphorbiales. Lawrence Berkeley Laboratory, Berkeley, California. Keywords: fuel properties/ Euphorbia

105. Calvin, M. 1986. Renewable fuels and materials, oil from plants. Cell Biophysiology 9:189-210.

Keywords: renewable energy/ oil/ carbon dioxide

106. Calvin, M., J. W. Otvos, S. E. Taylor, E. K. Nemethy, C. L. Skrukrud, D. R. Hawkins, and R. Lago. 1988.

Hydrocarbons and Energy from Plants, Final Report 1984-1987. ORNL/Sub/84-90435/1. Oak Ridge National Laboratory, Oak Ridge, Tennessee.

Keywords: hydrocarbons/ biomass crops/ renewable energy
107. Cantor, R. A., and C. G. Rizy. 1991. Biomass energy: Exploring the risks of commercialization in the United States of America. Bioresource Technology 35:13. Keywords: risk/ commercialization/ renewable energy

108. Cantrell, R. L., and P. A. Layton. 1986. Progeny tests: Site preparation and maintenance using herbicides. pp. 120-167. In Proceedings, 17th Annual Spring Symposium, Herbicides for Southern Forestry. Society of American Foresters, Bethesda, Maryland.

Keywords: herbicides/ site preparation/ progeny tests

109. Casler, M. D., and K. P. Vogel. 1999. Accomplishments and impact from breeding for increased forage nutritional value. Crop Science 39:12-20.

Keywords: breeding/ forage crops

110. Castello, J. D., and J. G. Berbee. 1978. The detection and elimination of viruses from hybrid poplar clones. Phytopathology News 12:186.

Keywords: viruses/ poplars, hybrid

111. Ceulemans, R. J., T. M. Hinckley, P. E. Heilman, J. G. Isebrands, and R. F. Stettler. 1989. Crown architecture in relation to productivity of Populus clones in the Pacific Northwest, U.S.A. Forest Tree Physiology (Proceedings of the International Symposium) 46:199s-201s. Keywords: crown architecture/ leaf area/ Populus/ productivity/ branch

112. Ceulemans, R. J., T. M. Hinckley, and I. Impends. 1989. Stomatal response of hybrid poplar to incident light, sudden darkening and leaf excision. Physiologia Plantarum 75:174-182.

Keywords: stomata/ cuticular conductance/ senescence/ Populus trichocarpal Populus deltoides

113. Ceulemans, R. J., T. M. Hinckley, J. G. Isebrands, R. F. Stettler, and B. M. Wiard. 1988. Leaf orientation and net 
photosynthesis of different Populus clones. Plant Physiology 86:71.

Keywords: Populus/ photosynthesis/ leaf orientation

114. Ceulemans, R. J., and J. G. Isebrands. 1996. Carbon acquisition and allocation. pp. 355-399. In Biology of Populus and its Implications for Management and Conservation. R. F. Stettler, Jr., H. D. Bradshaw, P. E. Heilman, and T. M. Hinckley (eds.). NRC Research Press, Ottawa, Canada.

Keywords: yields/ biomass crops/ carbon/ photosynthesis/ conversion technologies

115. Ceulemans, R. J., G. E. ScarasciaMugnozza, B. M. Wiard, J. H. Braatne, T. M. Hinckley, R. F. Stettler, J. G. Isebrands, and P. E. Heilman. 1992. Production physiology and morphology of Populus species and their hybrids grown under short rotation. I. Clonal comparisons of 4-year growth and phenology. Canadian Journal of Forest Research 22:1937-1948. Keywords: physiology/ morphology/ poplars/ hybrids/ short rotation woody crops/ clonal propagation/ phenology

116. Ceulemans, R. J., R. F. Stettler, R. F. Hinckley, J. G. Isebrands, and P. E. Heilman. 1990. Crown architecture of Populus clones as determined by branch orientation and branch characteristics. Tree Physiology 7:157-167.

Keywords: poplars/ genotypes/ clonal variations/ growth/ light/ crown architecture/ branch/ branch

117. Ceulemans, R. J., R. F. Stettler, T. M. Hinckley, P. E. Heilman, and J. G. Isebrands. 1988. Crown architecture and leaf demography in intensively cultured hybrid Populus clones. pp. 100-107. In Proceedings, 10th North American Forest Biology Workshop. J. Worral, J. LooDinkins, and D. P. Lester (eds.). University of British Columbia, Vancouver, British Columbia.

Keywords: branch/ dry matter/ leaf area/ poplars, hybrid/ crown architecture/ branch
118. Ceulemans, R. J., R. F. Stettler, T. M. Hinckley, J. G. Isebrands, and P. E. Heilman. 1989. Crown architecture of poplar (Populus) clones as determined by branch orientation and branch characteristics. In Proceedings, Dynamics of Ecophysiological Processes in Tree Crowns and Forest Canopies: ECOPHYS. U.S. Forest Service, North Central Forest Experiment Station, Rhinelander, Wisconsin.

Keywords: productivity/ branch/ clonal variations/ crown architecture/ Populus/ models, ECOPHYS/ branch

119. Chandler, P., and W. A. Geyer. 1979. Economic and energy-cost analyses for a theoretical energy forest plantation. Transactions of the Kansas Academy of Science 82:85.

Keywords: economics/ plantations

120. Chaput, L. J., and G. A. Tuskan. 1990. Field windbreak management and its effects on adjacent crop yield - a preliminary study. North Dakota Farm Research 48:2628.

Keywords: shelterbelts/ productivity

121. Chen, W., and T. C. Harrington. 2000. Genetic diversity of poplar leaf rust populations in Minnesota, Iowa and Missouri. Inoculum 15:24.

Keywords: Populus/ rusts/ diseases

122. Cherney, J. H. , K. D. Johnson, J. J. Volenec, and K. S. Anliker. 1988. Chemical composition of herbaceous grass and legume species grown for maximum biomass production. Biomass 17(4):215238.

Keywords: neutral detergent fiber/ cellulose/ hemicellulose/ lignin/ xylose/ arabinose

123. Cherney, J. H., K. D. Johnson, J. J. Volenec, E. J. Kladivko, and D. K. Greene. 1990. Evaluation of Potential Herbaceous Biomass Crops on Marginal Crops Land: 1) Agronomic Potential. ORNL/Sub/85-27412/5\&P1. Oak Ridge 
National Laboratory, Oak Ridge, Tennessee. Keywords: species selection/land/ site selection/ crop management/ composition, chemical/soils/ double crops/ interseeding

124. Chow, P., G. L. Rolfe, and L. E. Arnold. 1983. Chemicals, fiber, and energy from woody biomass. Illinois Research 25:11-13.

Keywords: fiber/ energy content/ biomass crops/ by-products

125. Chow, P., G. L. Rolfe, C. S. Lee, and T. A. White. 1983. The chemical properties of 2-year-old deciduous species. Journal of Applied Polymer Science, Symposia Series 557-575.

Keywords: composition, chemical

126. Christersson, L., and L. L. Wright (eds.). 2000. IEA Bioenergy: Task 17. Short-Rotation Crops for Bioenergy. ORNL/TM-2000/311. Oak Ridge National Laboratory, Oak Ridge, Tennessee. Keywords: International Energy Agency/ Short Rotation Woody Crops/ international activities

127. Christian, D. P. 1997. Wintertime use of hybrid poplar plantations by deer and medium-sized mammals in the Midwestern U.S. Biomass and Bioenergy 12(1):35-40. Keywords: mammals/ carnivores/ deer/ lagomorphs/ squirrels/ Populus/ poplars, hybrid/ habitat studies

128. Christian, D. P., P. T. Collins, J. M. Hanowski, and G. J. Niemi. 1997. Bird and small mammal use of short-rotation hybrid poplar plantations. Journal of Wildlife Management 61(1):171-182. Keywords: biomass crops/ birds/ habitat studies/ poplars, hybrid/ land use/ Minnesota/ Neotropical migrants/ northcentral states/ Populus/ short-rotation woody crops/ mammals

129. Christian, D. P., G. J. Niemi, J. M. Hanowski, and P. T. Collins. 1994.

Perspectives on biomass energy tree plantations and changes in habitat for biological organisms. Biomass and Bioenergy 6(1-2):31-39.

Keywords: biodiversity/ birds/ mammals/ biomass crops/ poplars, hybrid/ landscapes/ North America/ northcentral states

130. Christopher, R., and J. G.

Isebrands. 2000. Growth and contaminant uptake by hybrid poplars and willows in response to application of municipal landfill leachate. pp. 151. In Proceedings of the 21st Session of the International Poplar Commission Meeting, Poplar and Willow Culture: Meeting the Needs of Society and the Environment. J. G. Isebrands and J. Richardson (eds.). NC 215. North Central Research Station, St. Paul, Minnesota. Keywords: poplars, hybrid/ willows/ landfill leachate

131. Christopherson, N. S., and J. A. Mattson. 1990. Mechanization of the operational aspects of short-rotation forestry. Biomass 22:123-133.

Keywords: short rotation intensive culture/ harvesting/ production systems

132. Chun, Y. W., N. B. Klopfenstein, H. S. McNabb, Jr., and R. B. Hall. 1988. Biotechnological applications in Populus species. Journal of Korean Forestry Society 77:467-483.

Keywords: tissue culture/ biotechnology/ genetic modification/ Agrobacterium tumefaciens/ Populus

133. Clark III, A., D. R. Phillips, and D. J. Frederick. 1983. Biomass distribution and production of coastal plain hardwood stands. In Proceedings, Energy from Biomass and Wastes VII. D. L. Klass (ed.). Institute of Gas Technology, Chicago, Illinois.

Keywords: hardwoods/ productivity

134. Clark III, A., D. R. Phillips, and D. J. Frederick. 1985. Weight, Volume, and Physical Properties of Major Hardwood Species in the Gulf and Atlantic Coastal Plains. SE-250. U.S. Forest Service, Southeastern Forest Experiment Station, 
Asheville, North Carolina.

Keywords: biomass crops/ specific gravity/ moisture content/ bark percentage/ weight tables/ ash, green/ blackgum/ maples, red/ sweetgum/ water tupelo/ poplar, yellow/ hickories/ oaks/ hardwoods

135. Clark III, A., D. R. Phillips, and D. J. Frederick. 1986. Weight, Volume, and Physical Properties of Major Hardwood Species in the Piedmont. SE-255. U.S. Forest Service, Southeastern Experiment Station, Asheville, North Carolina.

Keywords: biomass crops/ specific gravity/ moisture content/ bark percentage/ weight tables/ hardwoods

136. Clark III, A., D. R. Phillips, and D. J. Frederick. 1986. Weight, Volume, and Physical Properties of Major Hardwood Species in the Upland-South. SE-257. U.S. Forest Service, Southeastern Experiment Station, Asheville, North Carolina. Keywords: volume tables/ biomass crops/ specific gravity/ moisture content/ bark percentage/ weight tables

137. Clarke, H. R. G., J. M. Davis, S. M. Wilbert, H. D. Bradshaw, Jr., and M. P. Gordon. 1994. Wound-induced and developmental activation of a poplar tree chitinase gene promoter in transgenic tobacco. Plant Molecular Biology 25:799815 .

Keywords: poplars/ chitinase gene promoter/ transgenic

138. Clendenen, G. W. 1996. Use of Harmonized Equations to Estimate Biomass and Leaf Area for Two Hybrid Poplar Clones in the Pacific Northwest. Biomass and Bioenergy 11(6):475-482.

Keywords: models/ Populus/ cottonwoods/ stand density/ yields/ leaf area/ silviculture/ genotypes/ poplars, hybrid/ biomass equations/ stand density/ yields

139. Cline, G., J. D. Rhodes, and P. Felker. 1986. Micronutrient, phosphorus and $\mathrm{pH}$ influences on growth and leaf tissue nutrient levels of Prosopis alba and
Prosopis glandulosa. Forest Ecology and Management 16:81-93.

Keywords: micronutrients/ phosphorus/ pH/ growth/ leaves/ Prosopis alba/ Prosopis glandulosa/ nitrogen fixation/ fuelwood/ zinc/ nutrients

140. Coleman, M. D. , R. E. Dickson, and J. G. Isebrands. 1996. Proceedings, 1995 Meeting of the Northern Global Change Program. NE-214. J. Hom, R. Birdsey, and K. O'Brian (eds.). USDA Forest Service, Radnor, Pennsylvania.

Keywords: roots/ growth/ respiration/ aspens/ ozone/ carbon dioxide

141. Coleman, M. D. , R. E. Dickson, J. G. Isebrands, and D. F. Karnosky. 1995. Carbon allocation and partitioning in aspen clones varying in sensitivity to tropospheric ozone. Tree Physiology 15:593-604.

Keywords: pollution/ carbohydrates/ photosynthesis/ Populus tremuloides/ carbon/ aspens

142. Coleman, M. D., R. E. Dickson, J. G. Isebrands, and D. F. Karnosky. 1996. Root growth and physiology of potted and field-grown trembling aspen exposed to tropospheric ozone. Tree Physiology 16:145-152.

Keywords: roots/ aspens/ ozone/ physiology

143. Coleman, M. D. , J. G. Isebrands, R. E. Dickson, and D. F. Karnosky. 1995. Photosynthetic productivity of aspen clones varying in sensitivity to tropospheric ozone. Tree Physiology 15:585-592.

Keywords: biomass crops/ leaf development/ photosynthesis/ Populus tremuloides/ pollution

144. Colletti, J. P. 1989. The Amana Project. Ames Forester 76:15-18.

Keywords: monoculture/ short rotation intensive culture/ maples, silver

145. Colletti, J. P., L. Rule, A. Skadberg, D. Schultz, C. W. Mize, R. B. Hall, and

P. H. Wray. 1991. Agroforestry systems 
for the Midwest. Ames Forester 78:10-13. Keywords: multi-cropping/ agroforestry

146. Colletti, J. P., L. Rule, A. Skadberg, D. Schultz, C. W. Mize, R. B. Hall, and P. H. Wray. 1991. Land application of sludge to forest and herbaceous energy crops. Ames Forester 78:24-30.

Keywords: sludge/ forests/ energy crops, herbaceous/ energy crops/ multi-cropping/ alley cropping/ sludge/ nitrogen/ woody crops/ biomass crops/ poplars, hybrid/ switchgrass/ Panicum virgatum/ sorghum/ rye/ crambe/ yields

147. Collins, M. 1991. Biomass production by nitrogen fertilized switchgrass monocultures and mixtures with bigflower vetch. pp. 10. In Proceedings: 1991 Southern Biomass Conference. Louisiana Department of Agriculture and Forestry, Baton Rouge, Louisiana.

Keywords: grasses/ switchgrass/ Panicum virgatum/ annuals/ fertilization

148. Collins, M. 1994. Biomass Production By Fescue and Switchgrass Alone and in Mixed Swards with Legumes Final Report. ORNL/Sub/88-SC617. Oak Ridge National Laboratory, Oak Ridge, Tennessee.

Keywords: biomass crops/ production/ fescue/ switchgrass/ Panicum virgatum/ legumes

149. Comer, C. W., L. F. Conde, D. L. Rockwood, and T. F. Geary. 1986. Casuarina cultural improvement in Florida. Nitrogen Fixing Tree Research Reports 4:53-56.

Keywords: Casuarina/ crop management

150. Comer, C. W., and D. L. Rockwood. 1984. Screening of Eucalyptus species for coppice productivity. pp. 95-97. In Proceedings, Sixth Southern Forest Biomass Workshop. University of Georgia, Athens, Georgia.

Keywords: planting density/ cold hardiness/ soil types/ Eucalyptus/ coppice
151. Comer, C. W., D. L. Rockwood, and H. Riekerk. 1983. Frost tolerant Eucalyptus from north Florida. pp. 377-382. In Proceedings, Frost Resistant Eucalyptus

Symposium. International Union of Forestry Research Organizations, Ljubljana,

Yugoslavia.

Keywords: Eucalyptus/ cold hardiness

152. Conde, L. F. 1980. Growth studies on Melaleuca. pp. 23-28. In Proceedings, Melaleuca Symposium. R. K. Geiger (ed.). Florida Division of Forestry, Tallahassee, Florida.

Keywords: Melaleuca/ growth

153. Conde, L. F., and J. B. Huffman. 1978. Energy utilization from biomass, from fuel plantations. pp. 43-64. In Proceedings, 10th Spring Symposium, Society of American Foresters Florida Section. University of Florida, Gainesville, Florida.

Keywords: biomass crops/ biomass crops/ energy

154. Conde, L. F., and D. L. Rockwood. 1979. Energy plantation potential in Florida. pp. 2-11. In Proceedings, Conference on Alternative Energy Sources for Florida. University of Florida, Gainesville, Florida. Keywords: short rotation woody crops/ pines/ Eucalyptus/ Melaleuca/ plantations

155. Conger, B. V. 1997.

Micropropagation by node culture. Rice

Biotechnol. Quart. 30:21-22.

Keywords: micropropagation/ nodes

156. Conger, B. V. 1999. Genetic transformation of forage grasses. pp. 49-58. In Molecular and Cellular Technologies for Forage Improvement. E. C. Brummer, N. S. Hill, and C. A. Roberts (eds.). Crop Science Society of America, Madison, Wisconsin. Keywords: genetic modification/ forage crops

157. Conger, B. V. 2002. Development of In Vitro Systems for Switchgrass (Panicum 
virgatum) - Final Report for 1992 to 2002. ORNL/SUB-02-11XSY161/01. Oak Ridge National Laboratory, Oak Ridge, Tennessee. Keywords: switchgrass/ micropropagation/ transformation/ tissue culture/ regeneration

158. Converse, T. E., and D. R. Betters. 1995. Biomass yield equations for short rotation black locust plantations in the Central Great Plains. Biomass and Bioenergy 8(4):251-254.

Keywords: short rotation woody crops/ plantations/ regression analysis/ biomass crops/ locusts, black/ yields

159. Couto, L., and D. R. Betters. 1995. Short-Rotation Eucalypt Plantations in Brazil: Social and Environmental Issues. ORNL/TM-12846. Oak Ridge National Laboratory, Oak Ridge, Tennessee. Keywords: Eucalyptus/ Brazil/ biodiversity/ agroforestry

160. Couto, L., D. R. Betters, and L. L. Wright. 1994. Technical aspects of commercial eucalypt plantations in Brazil: An overview. In Proceedings: IV Reunion Nacional de Plantaciones Forestales, SARH INIFAP. Info. not available.

Keywords: Eucalyptus/ plantations/ Brazil

161. Couto, L., L. R. Graca, and D. R. Betters. 1993. Energy from wood biomass: The experience of the Brazilian forest sector. pp. 42-53. In Proceedings of the First Biomass Conference of the Americas: Energy, Environment, Agriculture, and Industry. NREL/CP-200-5768. National Renewable Energy Laboratory, Golden, Colorado.

Keywords: wood biomass/ Brazil/ forests/ fuelwood/ Eucalyptus/ Pinus

162. Couto, L., L. R. Graca, D. R. Betters, and C. A. M. Passos. 1993. Agroforestry as an alternative to reduce establishment costs of short-rotation eucalypt plantations in southeastern Brazil. pp. 23-24. In The Third North American Agroforestry Conference - Opportunities for Agroforestry in the Temperate Zone
Worldwide. Iowa State University Press, Ames, Iowa.

Keywords: agroforestry/ intercropping/ corn/ beans/ plantations/ economics/

Eucalyptus/ establishment

163. Cowles, J. R., and H. W. Scheld. 1987. Cultural and Management Practices for the Chinese Tallow Tree as a Biomass Fuel Source. ORNL/Sub/81-09059/1. Oak Ridge National Laboratory, Oak Ridge, Tennessee.

Keywords: Sapium sebiferum/ fertilization/ crop management

164. Coyle, D. R., J. D. McMillin, R. B. Hall, and E. R. Hart. 2001. Cottonwood leaf beetle (Coleoptera: Chrysomelidae) performance on eight Populus hybrids. pp. 748-756. In National Meeting of the Entomological Society of America. Keywords: leaf beetle/ poplars, hybrid/ Chrysomela scripta/ Populus/ larvae/ short rotation woody crops

165. Coyle, D. R., J. D. McMillin, and E. R. Hart. 1999. Pupal and adult parameters as potential indicators of cottonwood leaf beetle (Coleoptera: Chrysomelidae) fecundity and logevity. Great Lakes Entomologist 32:107-113. Keywords: cottonwoods/ diseases/ Populus/ leaf beetle/ chrysomela

166. Coyle, D. R., J. D. McMillin, and E. R. Hart. 2000. Laboratory and field evaluations of two Bacillus thuringiensis formulations, Novodor and Raven for control of the cottonwood leaf beetle (Coleoptera: Chrysomelidae). Journal of Economic Entomology 93(3):713-720. Keywords: leaf beetle/ pesticides/ diseases/ Populus

167. Crabb, T. B. 1982. Eucalyptus plantations for energy production in Hawaii. pp. 167-172. In Proceedings, Governor's Energy Conference: Hawaii's Energy Options for the 80s. U.S. Forest Service, Honolulu, Hawaii.

Keywords: Eucalyptus/ energy 
168. Crabb, T. B., and T. H. Schubert. 1989. Economics of Eucalyptus plantations for biomass in Hawaii. pp. 113-123. In Proceedings, Third Pacific Basin Biofuels Workshop. University of Hawaii, Hawaii Natural Energy Institute, Honolulu, Hawaii. Keywords: economics/ yields/ crop management/ harvesting/ Eucalyptus

169. Crist, J. B., J. G. Isebrands, and N. D. Nelson. 1979. Suitability of intensively grown Populus raw material for industry. pp. 65-74. In Proceedings: 16th Annual Meeting of North American Poplar Council. North American Poplar Council, Thompsonville, Minnesota.

Keywords: poplars/ short rotation intensive culture

170. Crow, T. R. 1988. A guide to using regression equations for estimating tree biomass. Northern Journal of Applied Forestry 5:15-22.

Keywords: models/ yields/ biomass estimates

171. Crow, T. R., J. G. Isebrands, H. M. Rauscher, and R. E. Dickson. 1987.

Effects of canopy architecture on photosynthetic production in Populus seedings: A simulation study. pp. 286. In Proceedings, 72nd Annual Meeting of Ecological Society of America. Ohio State University Press, Columbus, Ohio.

Keywords: poplars/ photosynthesis

172. Crow, T. R., and H. M. Rauscher. 1986. Silvicultural research: Theory and applications. pp. 334-345. In Proceedings, 18th IUFRO World Congress. International Union of Forestry Research Organizations, Norway.

Keywords: ecosystems/ ecology/ silviculture

173. Crow, T. R., H. M. Rauscher, D. A. Michael, J. G. Isebrands, and D. I. Dickmann. 1986. POPGROW: An ecophysiological growth model. pp. 30. In Proceedings, Conference Northern Hardwood Resource: Management and
Potential. Michigan Technological University, Houghton, Michigan.

Keywords: poplars/models/ growth

174. Cullis, C. A. 1990. DNA

rearrangements in response to environmental stress. Advances in Genetics 28:73-97.

Keywords: DNA/ environmental effects/ genome size/ transposable elements

175. Cunningham, M. W. 1986. Genetic variation in rooting ability of American sycamore cuttings. pp. 6. In Proceedings, 1986 TAPPI Research and Development Conference. TAPPI Press, Atlanta, Georgia. Keywords: sycamores/ Platanus occidentalis/ roots/ genetic variations

176. Curtin, D. T., and P. E. Barnett. 1986. Development of Forest Harvesting Technology; Application in Short Rotation Intensive Culture (SRIC) Woody Biomass. Technical Note B58. Tennessee Valley Authority, Office of Agricultural and Chemical Development, Muscle Shoals, Alabama.

Keywords: timber/ short rotation intensive culture/ harvesting/ stems/ stocking/ productivity

177. Cushman, J. H., J. L. Elmore, and A. F. Turhollow. 1985. Herbaceous Energy Crops Program: Annual Progress Report for FY 1984. ORNL-6221. Oak Ridge National Laboratory, Oak Ridge, Tennessee.

Keywords: energy crops, herbaceous/ crops, lignocellulosic/ wetlands/ species selection/ oilseeds/ economics

178. Cushman, J. H., and J. W. Ranney. 1982. Short rotation growth of hardwoods for energy applications across the United States: Field results and economics. pp. 109-132. In Proceedings, Energy from Biomass and Wastes VI. D. L. Klass (ed.). Institute of Gas Technology, Chicago, Illinois.

Keywords: biomass crops/ wastes/ short rotation woody crops/ economics/ hardwoods 
179. Cushman, J. H., and A. F.

Turhollow. 1991. Selecting herbaceous energy crops for the Southeast and Midwest/Lake States. pp. 465-480. In Proceedings, Energy from Biomass and Wastes XIV. D. L. Klass (ed.). Institute of Gas Technology, Chicago, Illinois. Keywords: energy crops, herbaceous/ species selection/ regional analysis/ conversion technologies/ growth responses

180. Cushman, J. H., A. F. Turhollow, and J. W. Johnston. 1986. Herbaceous Energy Crops Program: Annual Progress Report for FY 1985. ORNL-6263. Oak Ridge National Laboratory, Oak Ridge, Tennessee.

Keywords: energy crops, herbaceous/ crops, lignocellulosic/ wetlands/ species selection/ oilseeds/ economics/ breeding/ environmental effects

181. Cushman, J. H., A. F. Turhollow, and J. W. Johnston. 1987. Herbaceous Energy Crops Program: Annual Progress Report for FY 1986. ORNL-6369. Oak Ridge National Laboratory, Oak Ridge, Tennessee.

Keywords: energy crops, herbaceous/ crops, lignocellulosic/ wetlands/ species selection/ oilseeds/ economics/ breeding/ environmental effects

182. Cushman, J. H., A. F. Turhollow, and J. W. Johnston. 1989. Herbaceous Energy Crops Program: Annual Progress Report for FY 1987. ORNL-6514. Oak Ridge National Laboratory, Oak Ridge, Tennessee.

Keywords: energy crops, herbaceous/ crops, lignocellulosic/ species selection/ oilseeds/ economics/ breeding/ environmental effects/ erosion

183. Cushman, J. H., L. L. Wright, and K. Shaw. 1991. Energy crops for biofuels. The World \& I 6(8):334-341.

Keywords: biomass crops/ conversion technologies/ environmental effects/ energy crops, herbaceous/ woody crops/ tissue culture
184. Cushman, J. H., L. L. Wright, J. L. Trimble, and J. W. Ranney. 1983. Short Rotation Woody Crops Program: Annual Progress Report for 1982. ORNL-5973. Oak Ridge National Laboratory, Oak Ridge, Tennessee.

Keywords: short rotation intensive culture/ hardwoods/ establishment/ crop management/ species selection/ genetic modification/ economics

185. Cushman, J. H., L. L. Wright, J. L. Trimble, and J. W. Ranney. 1984. Shortrotation intensive culture of hardwoods. pp. 5-14. In 1984 International Bio-energy Directory and Handbook. P. F. Bente, Jr. (ed.). BioEnergy Council, Washington, DC. Keywords: short rotation intensive culture/ hardwoods/ species selection/ crop management/ genetic modification

186. Danfield, W., J. Martishus, and E. A. Hansen. 1983. Application Date Affects Herbicide Tolerance of Hybrid Poplars. NC-301. U.S. Forest Service, North Central Forest Experiment Station, Rhinelander, Wisconsin.

Keywords: herbicides/ poplars, hybrid

187. Das, M. K., and C. M. Taliaferro. 1999. Genetic and phenotypic path analyses in switchgrass. pp. 84. In Agronomy Abstracts.

Keywords: genetics/ phenotype/ switchgrass/ Panicum virgatum

188. Das, M. K., and C. M. Taliaferro. 2000. Heritability of biomass yield in switchgrass. p. 101. In Agronomy Abstracts. American Society of Agronomy, Minneapolis, Minnesota.

Keywords: switchgrass/ Panicum virgatum/ heritability

189. Davis, J. M., H. R. G. Clarke, H. D. Bradshaw, Jr., and M. P. Gordon. 1991. Populus chitinase genes: Structure, organization, and similarity of translated sequences to herbaceous plant chitinases. Plant Molecular Biology 17:631-639. 
Keywords: cottonwoods/ genotypes/ phylogeny/ wounding

190. Davis, T. D., and B. E. Haissig. 1990. Chemical control of adventitious root formation in cuttings. PGRSA Quarterly 18:17.

Keywords: clonal propagation/ tissue culture/ roots

191. Dawson, D. H., J. Zavitkovski, and J. G. Isebrands. 1980. Managing forests for maximum biomass production. pp. 3642. In The Role of Chemical Engineering in Utilizing the Nation's Forest Resources, AIChE Symposium Series. The American Institute of Chemical Engineers, New York. Keywords: forests/ biomass crops/ crop management

192. Dawson, J. O. 1979. Nitrogen-fixing trees and shrubs. Illinois Research 21:8-9. Keywords: leguminous trees/ shrubs

193. Dawson, J. O., P. J. Dzialowy, G. Z. Gertner, and E. A. Hansen. 1982. Soil nitrogen patterns around Alnus glutinosa in mixed plantation with hybrid Populus. pp. 263-270. In Proceedings, 4th Central Hardwood Forest Conference. R. N. Mueller (ed.). University of Kentucky, Department of Forestry, Lexington, Kentucky.

Keywords: Alnus glutinosal Populus/ nitrogen/ soil properties

194. Dawson, J. O., P. J. Dzialowy, G. Z. Gertner, and E. A. Hansen. 1983.

Changes in soil nitrogen concentration around Alnus glutinosa in a mixed, shortrotation plantation with hybrid Populus. Canadian Journal of Forest Research 13:572-576.

Keywords: Alnus glutinosal Populus/ nitrogen/ soil properties

195. Dawson, J. O., and D. T. Funk. 1981. Seasonal changes in foliar nitrogen concentration of Alnus glutinosa. Forest Science 27:239-243.
Keywords: Alnus glutinosa/ alders/ nitrogen/ senescence

196. Dawson, J. O., D. T. Funk, R. R. Fitton, and G. Z. Gertner. 1980. Seasonal changes in leaf nitrogen concentration of Alnus glutinosa, A. rugosa, and A. serrulta. pp. 190-201. In Proceedings, Central Hardwood Forest Conference III. H. E. Garrett and G. S. Cox (eds.). University of Missouri-Columbia, Columbia, Missouri. Keywords: alders/ nitrogen/ senescence

197. Dawson, J. O., T. A. White, P. J. Dzialowy, and R. A. Herendeen. 1982. Forestry Research Report. 82-7. University of Illinois, Department of Forestry, UrbanaChampaign, Illinois.

Keywords: locusts, black/ nitrogen fixation/ coppice/ Robinia pseudoacacia

198. DeBell, D. S. 1979. Future potential for use of symbiotic nitrogen fixation in forest management. pp. 451-466. In Proceedings of Workshop, Symbiotic Nitrogen Fixation in the Management of Temperate Forests. U.S. Forest Service, Seattle, Washington.

Keywords: nitrogen fixation/ crop management/ forests/ economics

199. DeBell, D. S. 1990. Populus trichocarpa Torr. \& Gray: Black cottonwood. pp. 570-576. In Silvics of North America: Volume 2, Hardwoods. R. M. Burns and B. H. Honkala (eds.). Agricultural Handbook 654. U.S. Forest Service, Washington, DC.

Keywords: habitat studies/ climate/ growth/ reproduction/genetics/ cottonwoods

200. DeBell, D. S., and G. W. Clendenen. 1991. Woodgrass and wider spaced shortrotation systems for poplar production: Biomass yields over five years. pp. 411421. In Energy From Biomass and Wastes $X V$. D. L. Klass (ed.). Institute of Gas Technology, Chicago, Illinois. Keywords: environmental effects/ biomass crops/ pretreatments/ processing/ ethanol/ 
poplars/ woody crops/ combustion/ power generation

201. DeBell, D. S., G. W. Clendenen, C. A. Harrington, and J. C. Zasada. 1996. Tree growth and stand development in short-rotation Populus plantings: 7-year results for two clones at three spacings. Biomass and Bioenergy 11(4):253-269. Keywords: poplars/ cottonwoods/ stand density/ yields/ bioenergy/ intensive culture/ stems/ phenology/ leaf area/ sylleptic branching/ branch

202. Debell, D. S., G. W. Clendenen, and J. C. Zasada. 1993. Growing Populus biomass: Comparison of woodgrass versus wider-spaced short-rotation systems. Biomass and Bioenergy 4(5):305-313. Keywords: poplars/ biomass crops/ woodgrass/ short rotation woody crops/ propagation/ woodgrass/ cottonwoods/ coppice/ stand density/ stand density/ bioenergy/ plantations/ intensive culture

203. DeBell, D. S., T. G. Cole, and C. D. Whitesell. 1997. Growth, development, and yield in pure and mixed stands of Eucalyptus and Albizia. Forest Science 43(2):286-298.

Keywords: Albizia/ stand dynamics/ biomass crops/ species mixtures/ silviculture/ tropical forestry

204. DeBell, D. S., W. R. Harms, and C. D. Whitesell. 1989. Stockability: A major factor in productivity difference between Pinus taeda plantations in Hawaii and the Southeastern United States. Forest Science 35:708-719.

Keywords: stocking/ self-thinning/ pines/ yields/ stand density

205. DeBell, D. S., W. R. Harms, and J. C. Zasada. 1989. Yield of Populus hybrids in 'woodgrass' and other shortrotation density regimes. pp. 153-165. In Proceedings, Energy from Biomass and Wastes XII. D. L. Klass (ed.). Institute of Gas Technology, Chicago, Illinois.
Keywords: poplars, hybrid/ stand density/ planting density/ yields/ growth

206. DeBell, D. S., and C. A. Harrington. 1993. Deploying genotypes in short-rotation plantations: Mixtures and pure cultures of clones and species. The Forestry Chronicle 69:705-713.

Keywords: biomass crops/ intensive culture/ productivity/ nitrogen fixation/ silviculture/ operational considerations/ hybrids/ poplars/ Alnus/ Eucalyptus/ Albizia

207. DeBell, D. S., C. A. Harrington, G. W. Clendenen, M. A. Radwan, and J. C. Zasada. 1997. Increasing the Productivity of Biomass Plantations of Populus Species and Hybrids in the Pacific Northwest. Oak Ridge National Laboratory, Oak Ridge, Tennessee.

Keywords: short rotation woody crops/ Populus/ biomass crops/ poplars, hybrid

208. DeBell, D. S., C. A. Harrington, G. W. Clendenen, M. A. Radwan, and J. C. Zasada. 1997. Increasing the Productivity of Short-Rotation Populus Plantations. ORNL/M-5943. Oak Ridge National Laboratory, Oak Ridge, Tennessee. Keywords: short rotation woody crops/ Populus/ biomass crops/ poplars, hybrid

209. DeBell, D. S., C. R. Keyes, and B. L. Gartner. 2000. Wood density of Eucalyptus saligna grown in Hawaiin plantations: Effects of silvicultural practices and relation to growth rate. Australian Forestry 64(2):106-110.

Keywords: wood/ Eucalyptus salignal Hawaii/ silviculture/ growth rate

210. DeBell, D. S., and M. A. Radwan. 1979. Growth and nitrogen relations of coppiced black cottonwood and red alder in pure and mixed plantings. Botany Gazette 140:S97-S101.

Keywords: growth/ nitrogen/ cottonwoods/ alders/ establishment

211. DeBell, D. S., and M. A. Radwan. 1984. Foliar chemical concentrations in red 
alder stands of various ages. Plant and Soil 77:391-394.

Keywords: alders/ composition, chemical

212. DeBell, D. S., and M. A. Radwan. 1984. Repeated coppicing of cottonwood and alder affects soil properties. Agronomy Abstracts p. 258.

Keywords: cottonwoods/ alders/ soil properties/ coppice

213. DeBell, D. S., M. A. Radwan, C. A. Harrington, and D. L. Reukema. 1984. Culture of red alder (Alnus rubra) in biomass plantations. pp. 125-134. In Energy from Biomass: Building on a Generic Technology Base. ANL/CNSVTM-146. Argonne National Laboratory, Argonne, Illinois.

Keywords: Alnus rubra/ alders/ planting density/ rotation length

214. DeBell, D. S., M. A. Radwan, and J. M. Kraft. 1983. Influence of Red Alder on Chemical Properties of a Clay Loam Soil in Western Washington. PNW-313. U.S. Forest Service, Pacific Northwest Research Station, Seattle, Washington.

Keywords: alders/ soil properties

215. DeBell, D. S., R. F. Strand, and D. L. Reukema. 1978. Short-rotation production of red alder: Some options for future forest management. pp. 231-244. In Proceedings of Symposium: Utilization and Management of Alder. PNW-70. U.S. Forest Service, Pacific Northwest Forest and Range Experiment Station, Olympia, Washington. Keywords: short rotation woody crops/ production/ alders/ crop management/ forests/ pulpwood

216. DeBell, D. S., and T. C. Turpin. 1983. Red alder. pp. 26-28. In Silvicultural Systems for the Major Forest Types of the United States. Agricultural Handbook \# 445. U.S. Department of Agriculture, Washington, DC.

Keywords: Alnus/ growth/ alders
217. DeBell, D. S., and C. D. Whitesell. 1986. Admixing Albizia to supply nitrogen for Eucalyptus plantations in Hawaii. pp. 209. In Proceedings, IEA/BA Task II Workshop: Production Technology, Economics and Nutrient Cycling. ENFOR Secretariat, Ottawa, Ontario, Canada. Keywords: Albizia/ Eucalyptus/ nitrogen

218. DeBell, D. S., and C. D. Whitesell. 1988. Diameter-Density Relationships Provide Tentative Spacing Guidelines for Eucalyptus saligna in Hawaii. Research Note PSW-397. U.S. Forest Service, Pacific Southwest Forest Experiment Station, Berkeley, California.

Keywords: Eucalyptus saligna/ wood/ stand density

219. DeBell, D. S., C. D. Whitesell, and T. B. Crabb. 1987. Benefits of Eucalyptus-Albizia Mixtures Vary By Site on Hawaii Island. PSW-187. U.S. Forest Service, Pacific Southwest Forest Experiment Station, Berkeley, California. Keywords: Eucalyptus/ Albizia/ nitrogen/ site characteristics

220. DeBell, D. S., C. D. Whitesell, and T. H. Schubert. 1985. Mixed Plantations of Eucalyptus and Leguminous Trees Enhance Biomass Production. PSW-175. U.S. Forest Service, Pacific Southwest Forest Experiment Station, Berkeley, California.

Keywords: Eucalyptus/ leguminous trees

221. DeBell, D. S., C. D. Whitesell, and T. H. Schubert. 1989. Using N2-fixing Albizia to increase growth of Eucalyptus plantations in Hawaii. Forest Science 35:64-75.

Keywords: Albizia/ Eucalyptus/ biomass crops/ nitrogen fixation/ legumes

222. Denchev, P. D., and B. V. Conger. 1994. Plant regeneration from callus cultures of switchgrass. Crop Science 34(6):1623-1627.

Keywords: regeneration/ callus/ tissue culture/ switchgrass/ Panicum virgatum 
223. Denchev, P. D., and B. V. Conger. 1995. In vitro culture of switchgrass: Influence of 2,4-d and picloram in combination with benzyladenine on callus initiation and regeneration. Plant Cell, Tissue and Organ Culture 40:43-48. Keywords: switchgrass/ herbicides/ Panicum virgatum/ tissue culture/ regeneration

224. DeWalle, D. R., and W. E. Sopper. 1983. Conjunctive use of soil warming and municipal waste water irrigation to enhance woody biomass production. Energy in Agriculture 2:37-50.

Keywords: poplars, hybrid/ planting density/ irrigation/ sycamores/ sweetgum/ soil warming/ wastewater

225. Dickmann, D. I. 1979. Physiological determinants of poplar growth under intensive culture. pp. 12-1 - 12-12. In Poplar Research, Management and Utilization in Canada, Report 12

(Proceedings of the North American Poplar Council Annual Meeting). D. C. F. Fayle, L. Zsuffa, and H. W. Anderson (eds.). 102. Ontario Ministry of Natural Resources, Ontario, Canada.

Keywords: physiology/ poplars/ growth/ intensive culture

226. Dickmann, D. I. 1992. Role of physiology in forest tree improvement. Silva Fennica 25(4):248-256.

Keywords: forests/ silviculture/ physiology/ tree improvement

227. Dickmann, D. I., M. A. Gold, and J. A. Flore. 1994. The ideotype concept and the genetic improvement of trees. pp. (Page numbers not listed). In Plant Breeding Reviews (Chapter 6). J. Janick (ed.). John Wiley \& Sons, New York. Keywords: short rotation woody crops/ breeding/ productivity/ genetic modification/ ideotype

228. Dickmann, D. I., K. W. Gottschalk, and J. H. Bassman. 1979. Physiological studies of growth and development of young hybrid poplars. pp. 123-132. In Proceedings, 1979 North American Poplar Council Annual Meeting. Poplar Council, Thompsonville, Minnesota.

Keywords: physiology/ poplars, hybrid/ silviculture/ forestry

229. Dickmann, D. I., and R. L. Hendrick. 1994. Modeling adventitious root system development in trees: Clonal poplars. pp. 203-218. In Biology of Adventitious Root Formation. T. D. Davis and B. E. Haissig (eds.). Plenum Press, New York.

Keywords: roots/ poplars/ roots/ models

230. Dickmann, D. I., and J. G. Isebrands. 1999. Caveat Emptor. American Nurseryman 189(5):60-65. Keywords: poplars, hybrid/ diseases/ genetics

231. Dickmann, D. I., and M. R. Koelling. 1981. Establishing Fuelwood Plantations in Michigan. E-1572. Michigan State University, East Lansing, Michigan. Keywords: fuelwood/ Michigan/ fuels, fossil

232. Dickmann, D. I., Z. Liu, P. V. Nguyen, and K. S. Pregitzer. 1992. Photosynthesis, water relations, and growth of two hybrid Populus genotypes during a severe drought. Canadian Journal of Forest Research 22:1094-1106.

Keywords: photosynthesis/ water relations/ poplars, hybrid/ poplars/ genotypes/ drought/ rainfall/ nitrogen/ leaf development

233. Dickmann, D. I., D. A. Michael, J. G. Isebrands, and S. Westin. 1990. Effects of leaf display on light interception and apparent photosynthesis in two contrasting Populus cultivars during their second growing season. Tree Physiology 7:7-20. Keywords: poplars/ leaf orientation/ light/ photosynthesis

234. Dickmann, D. I., H. M. Phipps, and D. A. Netzer. 1980. Cutting Diameter Influences Early Survival and Growth of 
Several Populus Clones. NC-261. U.S. Forest Service, North Central Forest Experiment Station, Duluth, Minnesota. Keywords: poplars/ clonal propagation/ plantations/ hardwoods/ cuttings

235. Dickmann, D. I., and K. S. Pregitzer. 1992. The structure and dynamics of woody plant root systems. pp. 95-123. In Ecophysiology of Short Rotation Forest Crops. C. P. Mitchell, J. B. FordRobertson, T. M. Hinckley, and L. Sennerby-Forsse (eds.). Elsevier Science Publishers Ltd., New York.

Keywords: roots/ ecophysiology/ short rotation woody crops

236. Dickmann, D. I., K. S. Pregitzer, and P. V. Nguyen. 1994. Net Assimilation and Photosynthate Allocation of Populus Clones Grown under Short-Rotation Intensive Culture: Physiological and Genetic Responses Regulating Yield - Final Report. ORNL/Sub/86-95903/4. Oak Ridge National Laboratory, Oak Ridge, Tennessee. Keywords: Populus/ poplars/ short rotation intensive culture/ genetics/ photosynthesis/ physiology

237. Dickmann, D. I., K. Steinbeck, and T. Skinner. 1985. Leaf area and biomass in mixed and pure plantations of sycamore and black locust in the Georgia Piedmont. Forest Science 31:509-517.

Keywords: leaf area/ biomass crops/ sycamores/ locusts, black/ soils/ Platanus occidentalis/Robinia pseudoacacia

238. Dickmann, D. I., and K. W. Stuart. 1983. In The Culture of Poplars in Eastern North America. Hickory Hollow Associates, Dansville, Michigan. Keywords: poplars/ Populus/ genetics/ hybridization/ silviculture

239. Dickson, R. E. 1985. Diurnal distribution of $14 \mathrm{C}$ in cottonwood: Changes within the plant and among different chemical fractions. Plant Physiology (Suppl.) 77:116.
Keywords: Populus deltoides/ cottonwoods/ carbon

240. Dickson, R. E. 1986. Carbon fixation and distribution in young Populus trees. pp. 409-426. In Proceedings, Crown and Canopy Structure in Relation to Productivity. T. Fujimori and D. Whitehead (eds.). Forestry and Forest Products Research Institute, Ibaraki, Japan. Keywords: poplars/ carbon

241. Dickson, R. E. 1987. Diurnal changes in leaf chemical constituents and 14C-partitioning in cottonwood. Tree Physiology 3:157-171.

Keywords: poplars/ leaf development/ carbon/ cottonwoods

242. Dickson, R. E. 1989. Carbon and nitrogen allocation in trees. Annales Des Sciences Forestieres (Forest Tree Physiology) 46:631s-647s.

Keywords: leaf development/ carbon/ nitrogen/ nitrogen

243. Dickson, R. E., and J. G. Isebrands. 1991. Leaves as regulators of stress response. pp. 3-34. In Response of Plants to Multiple Stresses. H. A. Mooney, W. E. Winner, E. J. Pell, and E. Chu (eds.). Academic Press, Inc., San Diego, California. Keywords: shoots/ carbon/ clonal variations

244. Dickson, R. E., and J. G. Isebrands. 1993. Carbon allocation terminology:

Should it be more rational? Bulletin of the Ecological Society of America 74:175-177. Keywords: carbon/ ecosystems/ photosynthesis

245. DiFazio, S. P., S. Leonardi, S. Cheng, and S. H. Strauss. 1999.

Assessing potential risks of transgene escape from forestry plantations. In Gene Flow and Agriculture: Relevance for Transgenic Crops, Symposium Proceedings No. 72. P. W. Lutman (ed.). British Crop Protection Council, Farnham, United Kingdom. Keywords: transgene/ forestry 
246. Dinus, R. J. 2000. Genetic

Modification of Short Rotation Poplar Biomass Feedstock for Efficient Conversion to Ethanol. ORNL/Sub/99-4500007253/1.

Oak Ridge National Laboratory, Oak Ridge, Tennessee.

Keywords: genetics/ poplars, short rotation/ biomass crops/ feedstocks/ conversion technologies/ ethanol

247. Dinus, R. J., D. R. Dimmel, R. P. Feirer, M. A. Johnson, and E. W. Malcolm. 1990. Modifying Woody Plants for Efficient Conversion to Liquid and Gaseous Fuels. ORNL/Sub/88-SC006/1. Oak Ridge National Laboratory, Oak Ridge, Tennessee.

Keywords: conversion technologies/ composition, chemical/ biosynthesis/ molecular genetics

248. Dinus, R. J., P. Payne, M. M. Sewell, V. L. Chiang, and G. A. Tuskan. 2001. Genetic modification of short rotation popular wood: Properties for ethanol fuel and fiber productions. Critical Reviews in Plant Sciences 20(1):51-69.

Keywords: quality/ lignin/ cellulose/ hemicellulose/ specific gravity/ species selection/ breeding/ markers, genetic/ genetic modification

249. Dinus, R. J., and G. A. Tuskan. 1997. Micropropagation, Genetic Engineering, and Molecular Biology of Populus. RM-GTR-297. US Forest Service, Fort Collins, Colorado. Keywords: genetics/ breeding/ propagation/ molecular genetics

250. Dippon, D. R. 1986. Slash and sand pine intensive short rotation culture:

Economic energy feedstock. pp. 52-57. In Proceedings of the 1985 Southern Forest Biomass Workshop: Seventh Annual Southern Forest Biomass Workshop. Florida Cooperative Extension Service, Institute of Food and Agricultural Sciences, University of Florida, Gainesville, Florida. Keywords: pines/ conversion technologies/ economics/ planting density/ rotation length/ biomass crops/ growth/ yields/ Pinus elliottii

251. Dippon, D. R., D. L. Rockwood, and C. W. Comer. 1986. Cost sensitivity analysis of Eucalyptus grandis woody biomass systems. pp. 143-156. In Biomass Energy Development. W. H. Smith (ed.). Plenum Publishing Corp., New York. Keywords: Eucalyptus grandis/ intensive culture/ economics/ short rotation woody crops/ planting density/ coppice/ harvesting

252. Dobbins, C. L., P. Preckel, A. Mdafri, J. Lowenberg-DeBoer, and D. Stucky. 1990. Evaluation of Potential Herbaceous Biomass Crops on Marginal Crops Land: 2) Economic Potential. ORNL/Sub/85-27412/5\&P2. Oak Ridge National Laboratory, Oak Ridge, Tennessee. Keywords: yields/ economics/ species selection/ land/ energy crops, herbaceous

253. Dolan, L. S., F. Kropp, and H. G. Sims. 1982. The economics of hardwood fuels produced on biomass plantations. pp. 63-108. In Proceedings, Energy from Biomass and Wastes VI. D. L. Klass (ed.). Institute of Gas Technology, Chicago, Illinois.

Keywords: economics/ fuelwood/ biomass crops

254. Donahue, R. A., T. D. Davis, P. M. Marquardt, C. H. Michler, D. R. Carter, D. E. Riemenschneider, B. E. Haissig, and J. G. Isebrands. 1992. Photosynthetic and growth analysis of genetically modified hybrid poplar. Plant Physiology 99:103. Keywords: photosynthesis/ growth patterns/ poplars, hybrid

255. Donahue, R. A., T. D. Davis, C. H. Michler, D. E. Riemenschneider, D. R. Carter, P. M. Marquardt, N. Sankhla, D. Sankhla, B. E. Haissig, and J. G. Isebrands. 1994. Growth, photosynthesis, and herbicide tolerance of genetically modified hybrid poplar. Canadian Journal of Forest Research 24:2377-2383. 
Keywords: photosynthesis/ herbicides/ poplars, hybrid/ growth/ molecular genetics

256. Donahue, R. A., and C. H. Michler. 1993. Effect of glyphosate on chlorophyll fluorescence in transgenic hybrid poplar. Plant Physiology (Abstracts of Papers for the Joint Annual Meeting of the American Society of Plant Physiologists and the Canadian Society of Plant Physiologists) 102:801.

Keywords: glyphosate/ chlorophyll/ poplars, hybrid/ clonal propagation/ herbicides/ photosynthesis

257. Downing, M. E. 1998. Bioenergy crop production economics, and valuation of environmental benefits (abstract). Journal of Soil and Water Conservation 55(2):172. Keywords: agriculture/ bioenergy/ conversion technologies/ economics/ feedstocks/ markets/ economics/ production/ switchgrass/ Panicum virgatum/ woody crops

258. Downing, M. E. 1999. Toward a concept of integrated opportunities - The case of hybrid poplar in West Central Minnesota (abstract). pp. 19-20. In The Sixth Conference on Agroforestry in North America, Land-use Management for the Future. Association for Temperate Agroforestry.

Keywords: poplars, hybrid/ Minnesota

259. Downing, M. E. , R. Bain, and R. P. Overend. 1996. Economic development through biomass systems integration: U.S. Energy Department feasibility studies. pp. 30-36. In Bioenergy '96, Partnerships to Develop and Apply Biomass Technologies. Keywords: feasibility/ feedstocks/ commercialization

260. Downing, M. E. , C. Demeter, M. Braster, C. Hanson, G. Larson, and T. A. Volk. 1998. Agricultural cooperatives and marketing bioenergy crops: Case studies of emerging cooperative development for agriculture and energy. pp. 100-110. In BioEnergy '98, Proceedings of the 8th Biennial Conference. Great Lakes Regional Biomass Energy Program, Chicago, Illinois.

Keywords: markets/ agricultural cooperatives/ energy crops/ bioenergy

261. Downing, M. E., and R. L. Graham. 1993. Evaluating a biomass resource: The TVA region-wide biomass resource assessment model. pp. 54-67. In Proceedings of the First Biomass Conference of the Americas: Energy, Environment, Agriculture, and Industry. NREL/CP-200-5768. National Renewable Energy Labortory, Golden, Colorado. Keywords: biomass resources/ models/ short rotation woody crops

262. Downing, M. E., and R. L. Graham. 1993. The role of natural resource and environmental economics in determining the trade-offs in consumption and production of energy inputs: The case of biomass energy crops. pp. 1802-1817. In Proceedings of the First Biomass Conference of the Americas: Energy, Environment, Agriculture, and Industry. NREL/CP-2005768. National Renewable Energy Laboratory, Golden, Colorado.

Keywords: environmental effects/ economics/ production/ energy balance/ energy crops

263. Downing, M. E., and R. L. Graham. 1995. Potential Supply and Cost of Biomass from Energy Crops in the TVA Region. ORNL-6858. Oak Ridge National Laboratory, Oak Ridge, Tennessee. Keywords: biomass crops/ economics/ energy crops

264. Downing, M. E., and R. L. Graham. 1996. Potential Supply and Cost of Biomass from Energy Crops in the Tennessee Valley Authority Region. Biomass and Bioenergy 11(4):283-303.

Keywords: biomass crops/ economics/ energy crops

265. Downing, M. E. , D. Langseth, T. Lundblad, R. B. Pierce, and R. Stoffel. 
1999. Minnesota wood energy scale-up project: A progress report 5 years after establishment. pp. 1703-1709. In Biomass, A Growth Opportunity in Green Energy and Value-Added Products - Proceedings of the 4th Biomass Conference of Americas. R. P. Overend and E. Chornet (eds.). Elsevier Science, Kidlington, Oxford, United Kingdom.

Keywords: Minnesota/ biomass energy/ conservation

266. Downing, M. E., D. Langseth, R. Stoffel, and T. Kroll. 1996. Large-scale hybrid poplar production economics: 1995 Alexandria, Minnesota, establishment cost and management. pp. 467-471. In Bioenergy '96, Partnerships to Develop and Apply Biomass Technologies.

Keywords: poplars, hybrid/ economics/ economics/ biomass energy/ crop management

267. Downing, M. E. , S. B. McLaughlin, and M. E. Walsh. 1995. Energy, economic, and environmental implications of production of grasses as biomass feedstocks. pp. 288-297. In Second Biomass Conference of the Americas. National Renewable Energy Laboratory, Golden, Colorado.

Keywords: energy/ economics/ environmental effects/ production/ grasses/ switchgrass/ Panicum virgatum/ feedstocks

268. Downing, M. E. , R. B. Pierce, and T. Kroll. 1996. Minnesota Wood Energy Scale-Up Project 1994 Establishment Cost Data. ORNL/TM-12914. Oak Ridge National Laboratory, Oak Ridge, Tennessee. Keywords: Minnesota/ biomass energy/ economics

269. Downing, M. E. , R. B. Pierce, and R. Stoffel. 1999. Hybrid poplar on conservation reserve program land: Farm producer information and education. pp. 1765-1769. In Biomass, A Growth Opportunity in Green Energy and ValueAdded Products - Proceedings of the 4th Biomass Conference of Americas. R. P.
Overend and E. Chornet (eds.). Elsevier Science, Kidlington, Oxford, United Kingdom.

Keywords: poplars, hybrid/ conservation

270. Downing, M. E., R. Stoffel, T. Kroll, and D. Langseth. 1997. Minnesota Wood Energy Scale-Up Project 1995 and 1996 Establishment Cost Data. ORNL/TM13393. Oak Ridge National Laboratory, Oak Ridge, Tennessee.

Keywords: Minnesota/ biomass energy/ economics

271. Downing, M. E., and G. A. Tuskan. 1995. Is there a need for site productivity functions for short-rotation woody crop plantings? pp. 207-215. In Second Biomass Conference of the Americas. National Renewable Energy Laboratory, Golden, Colorado.

Keywords: site characteristics/ short rotation woody crops/ Populus/ poplars, hybrid/ hardwoods

272. Downing, M. E. , M. E. Walsh, and S. B. McLaughlin. 1996. Perennial grasses for energy and conservation: Evaluating some ecological, agricultural, and economic issues. pp. 217-224. In Environmental Enhancement through Agriculture. W. Lockeretz (ed.). Tufts University School of Nutrition Science and Policy, Medford, Massachusetts.

Keywords: perennials/ environmental effects/ grasses/ energy/ economics/ switchgrass/ Panicum virgatum

273. Duffy, M., and V. Y. Nanhou. 2001. Costs of Producing Switchgrass for Biomass in Southern Iowa. PM 1866. Iowa State University.

Keywords: switchgrass/ Panicum virgatum/ economics/ Iowa/ biomass crops

274. Dunlap, J. M., J. H. Braatne, T. M. Hinckley, and R. F. Stettler. 1993. Intraspecific variation in photosynthetic traits of Populus trichocarpa. Canadian Journal of Botany 71:1304-1311.

Keywords: Populus trichocarpal 
cottonwoods/ poplars/ photosynthesis/ water-use efficiency

275. Dunlap, J. M., P. E. Heilman, and R. F. Stettler. 1992. Genetic variation and productivity of Populus trichocarpa and its hybrids. V. The influence of ramet position on 3-year growth variables. Canadian Journal of Forest Research 22:849-857. Keywords: poplars/ hybrids/ genetic variations/ clonal propagation

276. Dunlap, J. M., P. E. Heilman, and R. F. Stettler. 1994. Genetic variation and productivity of Populus trichocarpa and its hybrids. VII. Two-year survival and growth of native black cottonwood clones from four river valleys in Washington. Canadian Journal of Forest Research 24:1539-1549. Keywords: poplars/ hybrids/ genetic variations/ clonal propagation/ Populus trichocarpa

277. Dunlap, J. M., P. E. Heilman, and R. F. Stettler. 1995. Genetic variation and productivity of Populus trichocarpa and its hybrids. VIII. Leaf and crown morphology of native $P$. trichocarpa clones from four river valleys in Washington. Canadian Journal of Forest Research 25:1710-1724. Keywords: poplars/ hybrids/ genetic variations/ clonal propagation/ Populus trichocarpa

278. Dunlap, J. M., and R. F. Stettler. 1996. Genetic variation and productivity of Populus trichocarpa and its hybrids. IX. Phenology and Melampsora rust incidence of native black cottonwood clones from four river valleys in Washington. Forest Ecology and Management 87:233-256.

Keywords: poplars/ genecology/ shortrotation intensive-culture/ restoration

279. Dunlap, J. M., and R. F. Stettler. 1996. Genetic variation of Populus trichocarpa and its hybrids. IX. Phenology and Melampsora rust incidence of native black cottonwood clones from four river valleys in Washington. Forest Ecology and
Management 87:233-256.

Keywords: genetics/ Populus/ cottonwoods

280. Dunlap, J. M., and R. F. Stettler. 2001. Variation in leaf epidermal and stomatal traits of Populus trichocarpa from two transects across the Washington Cascades. Canadian Journal of Botany 79:528-536.

Keywords: Populus trichocarpal cottonwoods/ stomata/ adaptation/ acclimation/ genetic variations

281. Ehrenshaft, A. R. 1989. Short Rotation Woody Crops Program Publications and Presentations. ORNL/TM10848. Oak Ridge National Laboratory, Oak Ridge, Tennessee.

Keywords: short rotation woody crops/ information resources

282. Ehrenshaft, A. R., and L. L. Wright. 1989. The SRWCP Database Management System: Users Guide, Data Definitions, and Source Code. ORNL/TM-10820. Oak Ridge National Laboratory, Oak Ridge, Tennessee.

Keywords: short rotation woody crops/ information resources

283. Ehrenshaft, A. R., and L. L. Wright. 1991. The Short Rotation Woody Crops

Program data base. Bioresource Technology 36:241-246.

Keywords: yields/ site characteristics/ models/ short rotation woody crops/ information resources

284. Ek, A. R. 1980. Mensurational and Biomass Relations for Populus 'Tristis \#1' Under Intensive Culture. NC-260. U.S. Forest Service, North Central Forest Experiment Station, St. Paul, Minnesota. Keywords: crop management/ plantations/ hybrids/ yields/ short rotation intensive culture/ Populus tristis

285. Elbersen, H. W., W. R. Ocumpaugh, M. A. Hussey, M. A. Sanderson, and C. R. Tischler. 1998. Crown node elevation of switchgrass and kleingrass under low light. 
Crop Science 38(3):712-716.

Keywords: crown node/ switchgrass/

Panicum virgatum/ kleingrass

286. Elbersen, H. W., W. R. Ocumpaugh, M. A. Hussey, M. A. Sanderson, and C. R. Tischler. 1999. Field evaluation of switchgrass seedlings divergently selected for crown node placement. Crop Science 39(2):475-479.

Keywords: switchgrass/ Panicum virgatum/ seed/ crown node

287. Ellis, D. D., and B. H. McCown. 1988. The Potential of Biotechnology in the Biomass Production Program. ORNL/M606. Oak Ridge National Laboratory, Oak Ridge, Tennessee.

Keywords: species selection/ economics/ breeding/ biotechnology

288. Enebak, S. A., M. E. Ostry, and N. A. Anderson. 1999. Inoculation methods for selecting Populus tremuloides resistant to Hypoxylon canker. Canadian Journal of Forest Research 29(8):11921196.

Keywords: Populus tremuloides/ cankers

289. English, B. C. , R. R. Alexander, K. H. Loewen, S. A. Coady, G. V. Cole, and W. R. Goodman. 1991. Development of a Farm-Firm Modelling System for Evaluation of Herbaceous Energy Crops. ORNL/SUB/88-SC616/2. Oak Ridge National Laboratory, Oak Ridge, Tennessee. Keywords: models/ energy crops, herbaceous/ economics

290. English, B. C., K. D. Dillivan, M. A. Ojo, R. R. Alexander, and R. L. Graham. 1993. An evaluation of the regional supply of biomass at three midwestern sites. pp. 106-111. In Proceedings of the First Biomass Conference of the Americas: Energy, Environment, Agriculture, and Industry. NREL/CP-200-5768. National Renewable Energy Laboratory, Golden, Colorado.

Keywords: biomass crops/ conversion technologies/ biomass resources/ regional analysis

291. English, B. C. , K. D. Dillivan, M. A. Ojo, R. R. Alexander, and R. L. Graham. 1996. Regional Biomass Supply: Three Case Studies in the Midwest, U.S. ORNL/Sub/92-SK378. Oak Ridge National Laboratory, Oak Ridge, Tennessee.

Keywords: regional analysis/ biomass crops/ transportation/ yields/ economics/ switchgrass/ Panicum virgatum/ resources/ resource assessment

292. Etzenhouser, M. J., and D. R. Betters. 1994. Suitability for Short Rotation Tree Plantations in Eastern Colorado. TR94-4. Colorado State University, Fort Collins, Colorado. Keywords: short rotation woody crops/ plantations/ Colorado/ cottonwoods/ locusts, black/ elms, Siberian/ drought

293. Faltonson, R., D. Thompson, and J. C. Gordon. 1983. Propagation of Poplar Clones for Controlled-Environment Studies. NC-81. U.S. Forest Service, North Central Forest Experiment Station, Duluth, Minnesota.

Keywords: poplars/ clonal propagation

294. Fang, Y., and E. R. Hart. 2000.

Effect of cottonwood leaf beetle

(Coleoptera: Chrysomelidae) larval population levels on Populus terminal damage. Environ. Entomol. 29(1):43-46.

Keywords: leaf beetle/ larvae/ Populus/ Chrysomela scripta/ defoliation/ short rotation woody crops/ diseases

295. Fege, A. S., and G. N. Brown. 1984. Carbohydrate distribution in dormant Populus shoots and hardwood cuttings. Forest Science 30:999-1010.

Keywords: poplars/ sugar content/ starch/ hardwoods/ carbohydrates

296. Fege, A. S., and H. M. Phipps. 1984. Effect of collection date and storage conditions on field performance of Populus hardwood cuttings. Canadian Journal of 
Forest Research 14:119-123.

Keywords: poplars/ storage/ clonal

propagation

297. Fege, A. S., J. Zavitkovski, R. C. Schultz, J. O. Dawson, R. B. Hall, T. F. Strong, J. B. Crist, A. R. Ek, J. G. Isebrands, L. M. Moore, M. E. Ostry, and R. L Verch. 1983. Intensive Plantation Culture: 12 Years Research. NC-91. E. A. Hansen (ed.). U.S. Forest Service, North Central Forest Experiment Station, St. Paul, Minnesota.

Keywords: short rotation woody crops/ biomass crops/Alnus/ short rotation intensive culture/ poplars, hybrid/ propagation/ physiology/ production systems/ insects/ diseases/ economics/ alders

298. Felker, P. 1979. Mesquite: An all purpose arid land tree. pp. 89-132. In New Agricultural Crops. American Association for the Advancement of Science Symposium, Volume 38. G. A. Ritchie (ed.). Westview Press, Boulder, Colorado.

Keywords: mesquite/ arid lands

299. Felker, P. 1981. Uses of tree legumes in semi-arid regions. Economic Botany 32:174-186.

Keywords: arid lands/ leguminous trees/ semi-arid

300. Felker, P. 1984. Economic, environmental, and social advantages of intensively managed short rotation mesquite (Prosopis spp.) biomass energy farms. Biomass 5:65-77.

Keywords: mesquite/ Prosopis/ short rotation woody crops

301. Felker, P., G. H. Cannell, P. R. Clark, J. F. Osborn, and P. Nash. 1983. Biomass production of Prosopis species (mesquite), Leucaena and other leguminous trees grown under heat/drought stress.

Forest Science 19:592-606.

Keywords: Prosopis/ mesquite/ Cercidium floridium/ Olney tesota/ Parkinsonia aculeata/ arid lands/ desertification/ fuelwood/ agroforestry/ leguminous trees/

Leucaena

302. Felker, P., G. H. Cannell, J. F. Osborn, P. R. Clark, and P. Nash. 1983. Effects of irrigation on biomass production of 32 Prosopis (mesquite) accessions. Expl. Agriculture 19:187-198.

Keywords: irrigation/ biomass crops/ mesquite/ Prosopis

303. Felker, P., and P. R. Clark. 1980. Nitrogen fixation (acetylene reduction) and cross inoculation in 12 Prosopis (mesquite) species. Plant and Soil 57:177-186. Keywords: nitrogen fixation/ drought/ semiarid/ leguminous trees/ rangeland/ Prosopis

304. Felker, P., and P. R. Clark. 1981. Nodulation and nitrogen fixation (acetylene reduction) in desert ironwood (Olneya tesota). Oecologia 48:292-293.

Keywords: leguminous trees/ Olney tesota/ nitrogen fixation/ nodulation

305. Felker, P., and P. R. Clark. 1981. Rooting of mesquite (Prosopis) cuttings. Journal of Range Management 34:466-468. Keywords: Prosopis/ mesquite/ clonal propagation

306. Felker, P., and P. R. Clark. 1982. Position of mesquite (Prosopis spp.) nodulation and nitrogen fixation (acetylene reduction) in 3-m long phraetophytically simulated soil columns. Plant and Soil 64:297-305.

Keywords: Prosopis/nodulation/ nitrogen fixation/ drought/ semi-arid/ leguminous trees/ water potential

307. Felker, P., P. R. Clark, and G. H. Cannell. 1981. Variation in growth among 13 Prosopis (mesquite) species. Expl. Agriculture 17:209-218.

Keywords: mesquite/ Prosopis/ growth responses/ nitrogen fixation/ drought/ biomass crops/ semi-arid

308. Felker, P., P. R. Clark, A. E. Laag, and P. F. Pratt. 1981. Salinity tolerance of 
the tree legumes mesquite (Prosopis glandulosa var. torreyana, $P$. elutina, and $P$. articulata), algarrobo ( $P$. chilensis), kiawe (P. pallida), and tamarugo. Plant and Soil (Nitrogen Free Media.) 61:311-317. Keywords: leguminous trees/ mesquite/ Prosopis/ salinity/ stress

309. Felker, P., P. R. Clark, J. F. Osborn, and G. H. Cannell. 1980. Utilization of mesquite (Prosopis spp.) pods for ethanol production. pp. 65-78. In Tree Crops for Energy Production on Farms. Solar Energy Research Institute, Golden, Colorado. Keywords: mesquite/ Prosopis/ ethanol

310. Felker, P., P. R. Clark, J. F. Osborn, and G. H. Cannell. 1982. Biomass estimation in a young stand of mesquite (Prosopis spp.), ironwood (Olneya tesota), and paloverde (Cercidium floridum and Parkinsonia aculeata). Journal of Range Management 35:87-89.

Keywords: biomass resources/ Prosopis/ mesquite/ Olney tesota/ Cercidium floridium/ Parkinsonia aculeata/ resource assessment

311. Felker, P., P. R. Clark, J. F. Osborn, and G. H. Cannell. 1984. Prosopis pod production: A comparison of North American, South American, Hawaiian, and African germplasm in young plantations. Economic Botany 38:36-51.

Keywords: Prosopis/ genetic variations

312. Felker, P., J. Meyer, and S. Gronski. 1987. In Managing Mesquite for Lumber, Cattle and Wildlife. Texas A\&I University, Kingsville, Texas.

Keywords: mesquite/ Prosopis/ lumber/ wildlife/ crop management

313. Felker, P., D. Smith, M. Smith, R. L. Bingham, and I. Reyes. 1984. Evaluation of herbicides for use in transplanting

Leucaena leucocephala and Prosopis alba on semi-arid lands without irrigation. Forest Science 3:747-755.

Keywords: herbicides/ Leucaena leucocephala/ Prosopis alba/ mesquite/ semi-arid/ arid lands

314. Felker, P., D. Smith, and C. Wiesman. 1986. Influence of mechanical and chemical weed control on growth and survival of tree plantings in semiarid regions. Forest Ecology and Management 16:259-267.

Keywords: weed control/ Prosopis albal Leucaena leucocephala/ herbicides/ semiarid/ arid lands

315. Felker, P., D. Smith, C. Wiesman, and R. L. Bingham. 1989. Biomass production of Prosopis alba at 2 nonirrigated field sites in semiarid south Texas. Forest Ecology and Management 29:135150.

Keywords: Prosopis alba/ mesquite/ productivity/ semi-arid/ arid lands

316. Ferguson, K. D., D. W. Rose, D. C. Lothner, and J. Zavitkovski. 1981. Hybrid poplar plantations in the Lake States: A financial analysis. Journal of Forestry 79(10):664-667.

Keywords: economics/ poplars, hybrid/ plantations

317. Ferrell, J. E., L. L. Wright, and G. A. Tuskan. 1995. Research to develop improved production methods for woody and herbaceous biomass crops. pp. 197-206. In Second Biomass Conference of the Americas: Energy, Environment, Agricultural, and Industry. National Renewable Energy Laboratory, Golden, Colorado.

Keywords: production/ biomass crops/ short rotation woody crops/ energy crops, herbaceous/ renewable energy/ hybrids/ willows/ poplars

318. Fick, G. W. 1984. Simple simulation models for yield prediction applied to alfalfa in the Northeast. Agronomy Journal 76:235-239.

Keywords: models/ growth/ rainfall/ temperature/ soil properties/ alfalfa 
319. Fick, G. W., and D. W. Onstad.

1983. ALSIM 1 (Level Zero): Description, Performance and User Instructions for a Base-Line Model of Alfalfa Yield and Quality. Mimeo 83-26. New York State College of Agriculture and Life Sciences, Cornell University, Ithaca, New York. Keywords: models/ growth/ rainfall/ temperature/ soil properties/ alfalfa

320. Fick, G. W., R. A. Pfeifer, and D. J. Lathwell. 1994. Production patterns of perennial herbaceous biomass crops in the Great Lakes Region. Energy Sources 16:333-348.

Keywords: soil properties/ soils/ harvesting/ yields/ regression analysis/ energy crops, herbaceous/ productivity

321. Fillatti, J. J., B. E. Haissig, B. H. McCown, L. Comai, and D. E. Riemenschneider. 1987. The development of glyphosate tolerant Populus plants through expression of a mutant aroA gene from Salmonella typhimurium. In Genetic Manipulation of Woody Plants. J. W. Hanover and D. Keathley (eds.). Plenum Press, New York.

Keywords: poplars/ glyphosate/ herbicides/ Salmonella typhimerium

322. Fillatti, J. J., J. C. Sellmer, and B. H. McCown. 1986. Regeneration and transformation of Populus tissue. Journal of Horticultural Science 21:773.

Keywords: poplars/ genetic modification

323. Fillatti, J. J., J. C. Sellmer, B. H. McCown, B. E. Haissig, and L. Comai. 1987. Agrobacterium mediated transformation and regeneration of Populus. Molecular and General Genetics 206:192199.

Keywords: poplars/ genetic modification/ Agrobacterium tumefaciens

324. Fisher, R. F., and A. V. Mollitor. 1982. Eucalyptus responds dramatically to fertilization. Agronomy Abstracts (74th Annual Meeting of the American Society of Agronomy) p. 264.
Keywords: Eucalyptus/ fertilization/ crop management

325. Floyd, D. 1984. National Winter Rapeseed Variety Trial: 1983-84. University of Idaho, College of Agriculture, Moscow, Idaho.

Keywords: rapeseed/ selection

326. Frampton, Jr., L. J., and D. L. Rockwood. 1983. Genetic variation in biomass traits of sand and slash pines. Silvae Genetica 31:18-23.

Keywords: biomass crops/genetic variations/ pines

327. Franzluebbers, A. J., R. L. Haney, C. W. Honeycutt, H. H. Shomberg, and F. M. Hons. 2000. Flush of carbon dioxide following rewetting of dried soil relates to active organic pools. Soil Science Society of America Journal 64:613-623.

Keywords: carbon dioxide/ soils/ microbial biomass/ nitrogen

328. Franzluebbers, A. J., F. M. Hons, and D. A. Zuberer. 1994. Long-term changes in soil carbon and nitrogen pools in wheat management systems. Soil Science Society of America Journal 58(6):16391645.

Keywords: carbon, soil/ nitrogen/ wheat/ residues/ crop production

329. Franzluebbers, A. J., F. M. Hons, and D. A. Zuberer. 1995. Soil organic carbon, microbial biomass, and mineralizable carbon and nitrogen in sorghum. Soil Science Society of America Journal 59(2):460-466.

Keywords: carbon, soil/ microbial biomass/ carbon/ nitrogen/ sorghum

330. Franzluebbers, A. J., F. M. Hons, and D. A. Zuberer. 1995. Tillage and crop effects on seasonal soil carbon and nitrogen dynamics. Soil Science Society of America Journal 59(6):1618-1624.

Keywords: tillage/ carbon, soil/ nitrogen/ soybeans/ wheat/ microbial biomass 
331. Frederick, D. J. 1978. Fuel plantations: A renewable source of energy for North Carolina. pp. 91-92. In Proceedings, Energy Technologies and Policies for North Carolina. Environmental Studies Council, Raleigh, North Carolina. Keywords: plantations/ renewable energy/ biomass resources

332. Frederick, D. J. 1983. Biomass relationships of coastal plain hardwoods. pp. 74-80. In Proceedings, Natural Regeneration Short Course. North Carolina State University, Raleigh, North Carolina. Keywords: hardwoods/ biomass crops

333. Frederick, D. J., and W. E. Gardner. 1978. Wood as an energy source in North Carolina. pp. 131-132. In Proceedings, Energy Technologies and Policies for North Carolina. Environmental Studies Council, Raleigh, North Carolina.

Keywords: woody crops/ renewable energy/ biomass resources

334. Frederick, D. J., R. C. Kellison, W. E. Gardner, M. Williford, and T. K. Slichter. 1979. Species selection and silvicultural systems for producing fuels from woody biomass in the southeastern United States. pp. 387-392. In Proceedings, 3rd Annual Biomass Energy Systems Conference. Colorado School of Mines, Golden, Colorado.

Keywords: species selection/ silviculture/ woody crops/ biomass resources

335. Frederick, D. J., H. A. I. Madgwick, M. F. Jurgensen, and G. R. Oliver. 1981. Dry matter and nutrient relations in 8-yearold Acacia dealbata, Eucalyptus regnans and Pinus radiata. pp. 344. In Proceedings, Australian Forest Nutrition Workshop. Commonwealth Scientific and Industrial Research Organization, Canberra, Australia. Keywords: Acacia dealbatal Eucalyptus regnans/ Pinus radiata/ dry matter/ nutrients

336. Frederick, D. J., H. A. I. Madgwick, M. F. Jurgensen, and G. R. Oliver. 1985. Dry matter content and nutrient distribution in an age series of Eucalyptus regnans plantations in New Zealand. New Zealand Journal of Forestry Science 15:158-179. Keywords: biomass crops/ above-ground components/ leaf litter/ nutrients/ soils/ Eucalyptus regnans

337. Frederick, D. J., H. A. I. Madgwick, M. F. Jurgensen, and G. R. Oliver. 1985. Dry matter, energy, and nutrient contents of 8-year-old stands of Eucalyptus regnans, Acacia dealbata, and Pinus radiata in New Zealand. New Zealand Journal of Forestry Science 15:142-157.

Keywords: biomass crops/ nutrients/ aboveground components/ soils/ nitrogen/ Eucalyptus regnans/ Acacia dealbatal Pinus radiata

338. Frederick, D. J., H. A. I. Madgwick, M. F. Jurgensen, and G. R. Oliver. 1986. Seasonal development of a young plantation of Eucalyptus nitens. New Zealand Journal of Forestry Science 16:78-86.

Keywords: biomass crops/ leaf fall/ nutrients/ Eucalyptus nitens

339. Frederick, D. J., H. A. I. Madgwick, and G. R. Oliver. 1982. Wood basic density and moisture content of young Eucalyptus regnans grown in New Zealand. New Zealand Journal of Forestry Science 12:494-500.

Keywords: wood/ moisture content/ Eucalyptus regnans

340. Frederick, D. J., H. A. I. Madgwick, G. R. Oliver, and M. F. Jurgensen. 1985. Dry matter and nutrient content of 8-yearold Eucalyptus saligna growing at Taheke Forest. New Zealand Journal of Forestry Science 15:251-254.

Keywords: biomass crops/ above-ground components/ nutrients/ soils/ Eucalyptus saligna

341. Frederick, D. J., M. G. Messina, S. T. Gower, A. Clark III, and D. R. Phillips. 1984. Southeastern wetland hardwood forests: An emerging resource. pp. 277-283. In Proceedings, 1984 TAPPI 
Research and Development Conference.

TAPPI Press, Atlanta, Georgia.

Keywords: wetlands/ hardwoods/ biomass resources

342. Frederick, D. J., B. J. Stokes, and

D. T. Curtin. 1986. Field trials of a

Canadian biomass feller-buncher. pp. 17-

22. In Proceedings, 1985 Southern Forest

Biomass Workshop. University of Florida,

Gainesville, Florida.

Keywords: harvesting

343. Frederick, D. J., T. Tew, A. Clark III, and D. R. Phillips. 1987. Biomass, Nutrient and Energy Content of Upland

South Hardwood Forests. North Carolina State University, School of Forest

Resources, Raleigh, North Carolina.

Keywords: yields/ nutrients/ energy

content/ hardwoods

344. Frewen, B. E., T. H. Chen, G. T. Howe, J. M. Davis, Rohde A., W. Boerjan, and H. D. Bradshaw, Jr. 2000. QTL and candidate gene mapping of bud set and bud flush in Populus. Genetics 154:837-845. Keywords: quantitative trait loci (QTL)/ mapping, genetic/ Populus

345. Frewen, B. E., T. H. Chen, G. T. Howe, J. M. Davis, A. Rohde, W. Boerjan, and H. D. Bradshaw, Jr. 2000.

Quantitative trait loci and candidate gene mapping of bud set and bud flush in Populus. Genetics 154:837-845. Keywords: quantitative trait loci (QTL)/ mapping, genetic/ bud break/ bud flush/ Populus

346. Friend, A. L., M. D. Coleman, and J. G. Isebrands. 1993. First International Symposium on the Biology of Adventitious Root Formation. NC-154. U.S. Forest Service, North Central Forest Experiment Station, Duluth, Minnesota.

Keywords: roots/ carbon/ shoots/ woody crops

347. Friend, A. L., M. D. Coleman, and J. G. Isebrands. 1994. Carbon allocation to root and shoot systems of woody plants. pp. 245-273. In Biology of Adventitious Root Formation. T. D. Davis and B. E. Haissig (eds.). Plenum Press, New York. Keywords: roots/ carbon/ shoots/ woody crops

348. Friend, A. L., G. E. ScarasciaMugnozza, J. G. Isebrands, and P. E. Heilman. 1991. Quantification of twoyear-old hybrid poplar root systems: Morphology, biomass, and 14C distribution. Tree Physiology 8:109-119.

Keywords: poplars, hybrid/ roots/ morphology/ biomass crops/ carbon

349. Fritz, R. S., C. Moulia, and G. Newcombe. 1999. Resistance of hybrid plants and animals to herbivores, pathogens, and parasites. Annu. Rev. Ecol. Syst.

30:565-591.

Keywords: hybridization/ herbivores/ pathogens/ parasites/ fungi/ introgression/ hybrid zones/ Populus/ willows/ diseases

350. Gamble, G. G., and D. R. Betters. 1995. Farmer and Rancher Receptiveness to Short Rotation Tree Plantations in EastCentral Colorado. TR95-3. Colorado State University, Ft. Collins, Colorado.

Keywords: short rotation woody crops/ Colorado

351. Gardner, W. E. 1978. Energy from wood: Some perspectives. pp. 87-88. In Proceedings, Energy Technologies and Policies for North Carolina. Environmental Studies Council, Raleigh, North Carolina. Keywords: renewable energy/ woody crops

352. Gareau, R. M., D. L. Auld, and M. K. Heikkinen. 1990. Evaluation of Seven Species of Oilseeds as Spring Planted Crops for the Pacific Northwest. Progress Report No. 277. University of Idaho, Agriculture Experiment Station, Moscow, Idaho.

Keywords: Brassica/ Pacific Northwest/ oilseeds/ species selection 
353. Garten, Jr., C. T., and S. D. Wullschleger. 1999. Soil carbon inventories under a bioenergy crop (switchgrass): Measurement limitations. Journal of Environmental Quality 28:13591365.

Keywords: carbon, soil/ bioenergy/ switchgrass/ Panicum virgatum

354. Garten, Jr., C. T., and S. D. Wullschleger. 2000. Soil carbon dynamics beneath switchgrass as indicated by stable isotope analysis. Journal of Environmental Quality 29:1-9.

Keywords: carbon, soil/ switchgrass/ Panicum virgatum

355. Garton, S., M. A. Hosier, P. E. Read, and R. S. Farnham. 1981. In vitro propagation of Alnus glutinosa Gaertn. Journal of Horticultural Science 16:758759.

Keywords: Alnus glutinosa/ clonal propagation

356. Garton, S., P. E. Read, and R. S. Farnham. 1983. Effect of stock plant nutrition on the macro- and micropropagability of Salix. Acta Horticulturae 131:141-151.

Keywords: Salix/ nutrients/ propagation

357. Gebre, G. M., and T. J.

Tschaplinski. 2000. Role of Osmotic Adjustment in Plant Productivity, A Summary Report and Review of Current Literature. ORNL/TM-2000/6. Oak Ridge National Laboratory, Oak Ridge, Tennessee. Keywords: osmotic adjustment

358. Gebre, G. M., T. J. Tschaplinski, G. A. Tuskan, and D. E. Todd. 1998. Clonal and seasonal differences in leaf osmotic potential and organic solutes of five hybrid poplar clones grown under field conditions. Tree Physiology 18:645-652. Keywords: carbohydrates/ amino acids/ irrigation/ osmotic adjustment/ osmotic potential/ Populus/ potassium
359. Geimer, R. L., and J. B. Crist. 1980. Structural flakeboard from short-rotation, intensively cultured hybrid Populus clones. Forest Products Journal 30:42-48.

Keywords: flakeboard/ short rotation intensive culture/ poplars, hybrid

360. Geyer, W. A. 1978. Spacing and cutting cycle influence on short-rotation silver maple yield. Tree Planters' Notes 29:5-7, 26.

Keywords: stand density/ harvesting/ short rotation woody crops/ maples, silver/ biomass crops/ silage

361. Geyer, W. A. 1981. Growth, yield, and woody biomass characteristics of seven short-rotation hardwoods. Wood Science 13:209-215.

Keywords: growth/ yields/ short rotation woody crops/ hardwoods/ fiber

362. Geyer, W. A. 1989. Biomass potential in high density (wood grass) trials. pp. 117-123. In Proceedings, Energy from Biomass and Wastes XII. D. L. Klass (ed.). Institute of Gas Technology, Chicago, Illinois.

Keywords: stand density/ maples, silver/ alders/ poplars/ sycamores/ willows/ cottonwoods

363. Geyer, W. A. 1992. Great Plains Energy Forest: Final Report. ORNL/Sub/80-07934/7. Oak Ridge National Laboratory, Oak Ridge, Tennessee. Keywords: short rotation woody crops/ yields/ Kansas/ wood

364. Geyer, W. A. 1993. Influence of environmental factors on woody biomass productivity in the Central Great Plains, U.S.A. Biomass and Bioenergy 4:333-337. Keywords: biomass crops/ fuelwood/ short rotation woody crops/ energy crops/ environmental effects/ climate

365. Geyer, W. A., R. M. Argent, and W. P. Walawender. 1985. Biomass yield, wood properties and gasification behavior of 
7-year-old Siberian elm. Wood and Fiber Science 19:2.

366. Geyer, W. A., P. Chandler, and G. G. Naughton. 1979. Woody biomass plantations for fuelwood. Transactions of the Kansas Academy of Science 82:86-87. Keywords: fuelwood/ woody crops/ plantations

367. Geyer, W. A., and C. E. Long. 1988.

Tolerance of direct-seeded honey locust to preemergent herbicides in various soil types. Journal of Environmental Horticulture 6:46.

Keywords: Gleditsia triacanthos/ establishment/ toxicity/ herbicides/ survival rate/ growth/ soil types

368. Geyer, W. A., L. Melichar, and C. E. Long. 1987. Preemergent herbicide trials with direct-seeded black locust grown in different soils. Journal of Arboriculture 13:105-107.

Keywords: herbicides/ locusts, black/ establishment/ Robinia pseudoacacia

369. Geyer, W. A., and M. W. Melichar. 1986. Short-rotation forestry research in the United States. Biomass 9:125-133.

Keywords: short rotation woody crops/ biomass crops

370. Geyer, W. A., and G. G. Naughton. 1980. Biomass yield and cost analysis (4th year) of various tree species grown under a short-rotation management scheme in eastern Kansas. pp. 315-329. In Proceedings, Central Hardwood Forest Conference III. University of Missouri, Forestry Department, Columbia, Missouri. Keywords: biomass crops/ agroforestry/ fuelwood/ short rotation woody crops/ forestry/ rotation length/ economics

371. Geyer, W. A., and G. G. Naughton. 1980. Fuelwood for the University of Kansas steam-generating plant. Transactions of the Kansas Academy of Science 83:134-135.
Keywords: fuelwood/ conversion technologies/ agroforestry

372. Geyer, W. A., G. G. Naughton, L. Gould, and J. Strine. 1978. Energy forest. Transactions of the Kansas Academy of Science 81:102.

Keywords: renewable energy/ plantations

373. Geyer, W. A., G. G. Naughton, and K. L. Lynch. 1984. Variations in energy forest yields in the Great Plains. pp. 121122. In Proceedings, 1st National Meeting on Biomass $R \& D$ for Energy Applications. SERI/CP430-2430. Solar Energy Research Institute, Golden, Colorado.

Keywords: renewable energy/ plantations/ agroforestry

374. Girouard, P., M. E. Walsh, and D. A. Becker. 1999. Biocost-Canada: A new tool to evaluate the economic, energy, and carbon budgets of perennial energy crops. pp. 85-90. In Proceedings of the 4th Biomass Conference of the Americas Biomass, A Growth Opportunity in Green Energy and Value-Added Products. R. P. Overend and E. Chornet (eds.). Elsevier Science, Ltd, Kidlington, Oxford, United Kingdom.

Keywords: models, BIOCOST/ Canada/ economics/ energy/ carbon/ energy crops/ biofuels

375. Glumac, E. L., P. Felker, and I. Reyes. 1987. A comparison of cold tolerance and biomass production in Leucaena leucocephala, L. pulverulenta and L. retusa. Forest Ecology and Management 18:251-271.

Keywords: Leucaena leucocephalal Leucaena pulverulenta/ Leucaena retusal cold hardiness/ productivity

376. Glumac, E. L., P. Felker, and I. Reyes. 1987. Correlations between biomass productivity and soil and plant tissue nutrient concentrations for Leucaena leucocephala (K-8) growing on calcareous soils. Forest Ecology and Management 18:241-250. 
Keywords: Leucaena leucocephalal nutrients/ soil properties/ productivity

377. Gnewikow, L., J. P. Colletti, R. C. Schultz, and R. B. Hall. 1990. The Amana Project: Linking Agriculture and Forestry Through Sustainable Biomass Production. Fact Sheet. Iowa State University, Department of Forestry, Ames, Iowa. Keywords: economics/ production

378. Goncalves, P. D., and R. C. Kellison. 1980. Potential of Black Alder in the South. Technical Report No. 62. North Carolina State University, School of Forest Resources, Raleigh, North Carolina. Keywords: taxonomy/ Alnus/ alders/ diseases/ insects

379. Goodman, W. R. , S. A. Coady, and B. C. English. 1991. Biomass crop production on representative southeastern U.S. farms: Farm profitability, erosion control and the 1985 Food Security Act. Bioresource Technology 36:207-214. Keywords: switchgrass/ Panicum virgatum/ erosion/ economics/ policy

380. Gower, S. T., R. Lea, and D. J. Frederick. 1985. Aboveground energy production and distribution of southeastern hardwood swamp forests. Biomass 7:185197.

Keywords: wetlands/ hardwoods/ energy content

381. Grado, S. C., C. H. Strauss, P. R. Blankenhorn, and T. W. Bowersox. 1988. Short rotation woody biomass plantations: Technical requirements and costs for establishment. Biomass 17:277-289. Keywords: poplars/ establishment/ nursery, forest/ economics

382. Graham, R. L. 1994. An analysis of the potential land base for energy crops in the conterminous United States. Biomass and Bioenergy 6(3):175-189.

Keywords: land/ energy crops/ short rotation woody crops/ energy crops, herbaceous/ irrigation
383. Graham, R. L. 1998. Systems studies. In Accomplishments in Bioenergy Production Research 1995-1997. R. L. Gambles and G. Page (eds.). University of Toronto Press.

Keywords: models/ biomass crops

384. Graham, R. L., L. J. Allison, and D. A. Becker. 1996. ORECCL-Oak Ridge energy crop county level database. pp. 522529. In Bioenergy '96, Partnerships to Develop and Apply Biomass Technologies. Keywords: energy crops/ switchgrass/ Panicum virgatum/ short rotation woody crops/ data management

385. Graham, R. L., L. J. Allison, and D. A. Becker. 1997. ORECCL: Summary of a National Database on Energy Crop Landbase, Yields, and Costs. pp. 205-213. In Third Biomass Conference of the Americas: Energy, Environment, Agriculture, and Industry. Elsevier. Keywords: energy crops/ switchgrass/ Panicum virgatum/ poplars/ willows/ resource assessment/ models, ORECCL

386. Graham, R. L., and M. E. Downing. 1993. Renewable biomass energy:

Understanding regional scale environmental impacts. pp. 1566-1581. In First Biomass Conference of the Americas - Volume I - III. National Renewable Energy Laboratory, Golden, Colorado.

Keywords: biomass energy/ environmental effects/ industry

387. Graham, R. L., M. E. Downing, and M. E. Walsh. 1996. A framework to assess regional environmental impacts of dedicated energy crop production. Environmental Management 20(4):475-485.

Keywords: energy crops/ biomass crops/ environmental effects/ models

388. Graham, R. L., B. C. English, and C. E. Noon. 2000. A geographic information system-based modeling system for evaluating the cost of delivered energy crop feedstock. Biomass \& Bioenergy 18(4):309-329. 
Keywords: resource assessment/ switchgrass/ Panicum virgatum/ GIS/ models/ transportation/ United States/ feedstocks/ economics

389. Graham, R. L., B. C. English, C. E. Noon, H. I. Jager, and M. J. Daly. 1997.

Predicting switchgrass farmgate and delivered costs: An 11 state anlaysis. pp. 121-129. In Third Biomass Conference of the Americas: Energy, Environment, Agriculture, and Industry. Elsevier. Keywords: feedstocks/ resource assessment/ GIS/ models/ economics

390. Graham, R. L., D. D. Huff, M. R. Kaufmann, W. D. Shepperd, and J.

Sheehan. 1998. Bioenergy and watershed restoration in the mountainous regions of the west: What are the environmental/community issues? In BioEnergy '98: Expanding Bioenergy Partnerships.

Keywords: fuels/ fire management/ restoration/ biomass energy/ community issues/ sustainability/ environment

391. Graham, R. L., E. Lichtenberg, V. O. Roningen, H. Shapouri, and M. E. Walsh. 1995. The economics of biomass production in the United States. pp. 13141323. In Second Biomass Conference of the Americas. National Renewable Energy Laboratory, Golden, Colorado.

Keywords: economics/ biomass crops/ willows/ switchgrass/ Panicum virgatum/ feedstocks

392. Graham, R. L., W. Liu, M. E. Downing, C. E. Noon , M. J. Daly, and A. Moore. 1995. The effect of location and facility demand on the marginal cost of delivered wood chips from energy crops: A case study of the State of Tennessee. pp. 1324-1333. In Second Biomass Conference of the Americas. National Renewable Energy Laboratory, Golden, Colorado. Keywords: productivity/ short rotation woody crops/ Populus/ poplars, hybrid/ hardwoods
393. Graham, R. L., W. Liu, M. E. Downing, C. E. Noon, M. J. Daly, and A. Moore. 1997. The effect of location and facility demand on the marginal cost of delivered wood chips from energy crops: A case study of the State of Tennessee. Biomass and Bioenergy 13(3):117-123. Keywords: productivity/ short rotation woody crops/ Populus/ poplars, hybrid/ hardwoods

394. Graham, R. L., W. Liu, and B. C. English. 1996. The environmental benefits of cellulosic energy crops at a landscape scale. pp. 225-234. In Environmental Enhancement through Agriculture. W. Lockeretz (ed.). Tufts University School of Nutrition Science and Policy, Medford, Massachusetts.

Keywords: environmental effects/ energy crops/ landscapes/ biomass energy/ feedstocks/ poplars/ willows/ switchgrass/ Panicum virgatum

395. Graham, R. L., W. Liu, H. I. Jager, B. C. English, C. E. Noon, and M. J. Daly. 1996. A regional-scale GIS-based modeling system for evaluating the potential costs and supplies of biomass from biomass crops. pp. 444-450. In Bioenergy '96,

Partnerships to Develop and Apply Biomass Technologies.

Keywords: resource assessment/ transportation/ models/ feedstocks/ economics

396. Graham, R. L., R. D. Perlack, A. M. G. Prasa, J. W. Ranney, and D. B. Waddle. 1990. Greenhouse Gas Emissions in Sub-Saharan Africa. ORNL-6640. Oak Ridge National Laboratory, Oak Ridge, Tennessee.

Keywords: Africa/ greenhouse gases/ climate

397. Graham, R. L., and M. E. Walsh. 1995. Evaluating the economic costs, benefits and tradeoffs of dedicated biomass energy systems: The importance of scale. pp. 1428-1436. In Second Biomass Conference of the Americas. National 
Renewable Energy Laboratory, Golden, Colorado.

Keywords: economics/ biomass energy/ scale/ bioenergy/ energy crops

398. Graham, R. L., and M. E. Walsh. 1999. A National Assessment of Promising Areas for Switchgrass, Hybrid Poplar, or Willow Energy Crop Production. ORNL6944. Oak Ridge National Laboratory, Oak Ridge, Tennessee.

Keywords: switchgrass/ Panicum virgatum/ poplars, hybrid/ willows/ energy crops

399. Graham, R. L., L. L. Wright, and A. F. Turhollow. 1992. The potential for short-rotation woody crops to reduce U.S. $\mathrm{CO}_{2}$ emissions. Climate Change 22:223238.

Keywords: short rotation woody crops/ fuels, fossil/ carbon dioxide/ emissions/ biomass crops

400. Green, J. C., and D. I. Bransby. 1995. 'Alamo' switchgrass germination and seedling response to seed size. Agronomy Abstacts 117.

Keywords: switchgrass/ Panicum virgatum/ germination/ seedlings/ seed

401. Green, J. C., and D. I. Bransby. 1995. Effect of seed size on germination and seedling growth of Alamo switchgrass. pp. 23. In Abstracts of the 5th International Rangeland Conference.

Keywords: germination/ seedlings/ seed/ switchgrass/ Panicum virgatum

402. Green, T. H., G. F. Brown, L. Bingham, D. A. Mays, K. Sistani, J. D. Joslin, B. R. Bock, F. C. Thornton, and V. R. Tolbert. 1996. Environmental impacts of conversion of cropland to biomass production. pp. 918-924. In Bionergy '96, Partnerships to Develop and Apply Biomass Technologies. Southeastern Regional Biomass Energy Program, Muscle Shoals, Alabama.

Keywords: environmental effects/ cropland/ biomass crops
403. Griend, L. V., M. E. Feldman, and C. L. Peterson. 1990. Modeling combustion of alternative fuels in a DI diesel engine using KIVA. ASAE 33:342350 .

Keywords: models/ combustion/ fuels/ diesel fuels

404. Gunter, L. E., G. A. Tuskan, and S. D. Wullschleger. 1996. Diversity among populations of switchgrass based on RAPD markers. Crop Science 36:10171022.

Keywords: switchgrass/ Panicum virgatum/ germplasm/ genetic diversity

405. Gunter, L. E., G. A. Tuskan, and S. D. Wullschleger. 1999. Assessment of genetic variation at the DNA level among 'Alamo' seed sources (abstract). pp. 155. In 1999 Annual Meeting Abstracts; American Society of Agronomy, Crop Science Society of American, and Soil Science Society of America.

Keywords: genetics/ switchgrass/ seed

406. Gupta, S. D., and B. V. Conger. 1998. In vitro differentiation of multiple shoot clumps from intact seedlings of switchgrass. In Vitro Cell Development Plant 34(3):196-202.

Keywords: in vitro culture/ shoots/ seedlings/ switchgrass/ Panicum virgatum

407. Gupta, S. D., and B. V. Conger. 1998. Regeneration and ontogeny of multiple shoots from intact seedlings of switchgrass (Panicum virgatum L.). pp. 72. In IX International Association Plant Tissue Culture Congress Book of Abstracts. Keywords: regeneration/ ontogeny/ seedlings/ switchgrass/ Panicum virgatum

408. Gupta, S. D., and B. V. Conger. 1999. Somatic embryogenesis and plant regeneration from suspension cultures of switchgrass. Crop Science 39(1):243-247. Keywords: somatic embryogenesis/ regeneration/ switchgrass/ Panicum virgatum 
409. Haissig, B. E. 1987. Tissue culturebased biotechnology for Populus clones. pp. 155-176. In Proceedings, Energy from Biomass and Wastes X. D. L. Klass (ed.). Institute of Gas Technology, Chicago, Illinois.

Keywords: poplars/ tissue culture

410. Haissig, B. E. 1988. Future directions in adventitious rooting research. pp. 303310. In Adventitious Root Formation in Cuttings. T. D. Davis, B. E. Haissig, and N. Sankhla (eds.). Dioscorides Press, Portland, Oregon.

Keywords: clonal propagation/ tissue culture/ genetic modification/ roots

411. Haissig, B. E. 1989. Carbohydrate relations during propagation of cuttings from sexually mature Pinus banksiana trees. Tree Physiology 5:319-328. Keywords: roots/ photosynthesis/ starch/ metabolism/ propagation

412. Haissig, B. E. 1989. Removal of the stem terminal and application of auxin change carbohydrates in Pinus banksiana cuttings during propagation. Physiologia Plantarum 77:179-184.

Keywords: roots/ pines/ reducing sugar/ carbohydrates

413. Haissig, B. E. 1989. Status of forest tree vegetative regeneration for biotechnology. American Biotechnology Laboratory 7:48-51.

Keywords: clonal propagation/ genetic modification

414. Haissig, B. E. 1990. ATP concentrations in Pinus banksiana cuttings during adventitious rooting. Journal of Plant Physiology 136:499-502.

Keywords: roots/ pines/ propagation

415. Haissig, B. E. 1990. Reduced irradiance and applied auxin influence carbohydrate relations in Pinus banksiana cuttings during propagation. Physiologia Plantarum 78:455-461.
Keywords: roots/ auxin/ irradiance/ pines/ reducing sugar/ starch/ clonal propagation

416. Haissig, B. E., and T. D. Davis. 1994. A historical evaluation of adventitious rooting research to 1993. pp. 275-331. In Biology of Adventitious Root Formation. T. D. Davis and B. E. Haissig (eds.). Plenum Press, New York.

Keywords: roots/ clonal propagation/ harvesting

417. Haissig, B. E. , T. D. Davis, and D. E. Riemenschneider. 1992. Researching the controls of adventitious rooting. Physiologia Plantarum 84:310-317. Keywords: clonal propagation/ forestry/ genetic variations/ horticulture/ molecular biology/ DNA/ roots/ tissue culture/ roots

\section{Haissig, B. E., N. D. Nelson, and} G. H. Kidd. 1987. Trends in the use of tissue culture in forest improvement. Biotechnology 5:52-59.

Keywords: tissue culture/ biotechnology

419. Haissig, B. E., and D. E. Riemenschneider. 1986. Genetic engineering of hybrid poplars for herbicide tolerance. pp. 37-46. In Proceedings, Forest Products Research Conference 1986:

Matching Utilization Research with the Needs of Timber Managers. Forest Products Laboratory, Madison, Wisconsin.

Keywords: genetic modification/ poplars, hybrid/ herbicides/ Agrobacterium tumefaciens/ somaclonal variations

420. Haissig, B. E., and D. E. Riemenschneider. 1988. Genetic effects on adventitious rooting. pp. 47-60. In Adventitious Root Formation in Cuttings. T. D. Davis, B. E. Haissig, and R. Sankhla (eds.). Dioscorides Press, Portland, Oregon. Keywords: tissue culture/ clonal propagation/ harvesting/ breeding

421. Haissig, B. E., and D. E. Riemenschneider. 1993. Strategic planning for applying biotechnology to woody plant genetics and breeding. pp. 
485-500. In Micropropagation of Woody Plants, Chapter 29. M. R. Ahuja (ed.). Kluwer Academic Publishers, The Netherlands.

Keywords: biotechnology/genetics/ breeding

422. Hall, D. O., and J. I. Scrase. 1998 . Will biomass be the environmentally friendly fuel of the future? Biomass and Bioenergy 15(4/5):357-367.

Keywords: biomass energy/ environment/ life cycle analysis/ economics/ fuels

423. Hall, P. 1980. Wood: Tomorrow's fuel? Kansas State Agriculturist 19:12.

Keywords: woody crops/ biomass resources

424. Hall, R. B. 1986. Breeding strategy for Alnus, Populus, and Salix. pp. 78-94. In Proceedings of the Joint International Energy Agency Forestry Energy Programme and Food and Agricultural

Organization/Cooperative Network on Rural Energy Forest Energy Conference and Workshops on Research in Forestry for Energy. C. P. Mitchell, P. O. Nilsson, and L. Zsuffa (eds.). NR 49/1986. Swedish University of Agricultural Science, Sweden. Keywords: breeding/ Alnus/ poplars/ Salix

425. Hall, R. B. 1994 . Use of the crown competition factor concept to select clones and spacings for short-rotation woody crops. Tree Physiology 14:899-909.

Keywords: branch/ carbon/ crown architecture/ genotypes/ poplars/ productivity/ rotation length

426. Hall, R. B. 1997. Floodplain forests (lumber and firewood). pp. 11-16. In Farming the Floodplain: The Potential of Flood Tolerant Floodplain Uses. The Wetlands Initiative, Chicago, Illinois. Keywords: floodplain/ forests

427. Hall, R. B. 1999. Forest genetics (cloning). pp. 175-178. In Yearbook of Science and Technology 2000. McGrawHill, New York.

Keywords: genetics
428. Hall, R. B., and D. Burgess. 1990. Evaluation of Alnus species and hybrids. Biomass 22:21-34.

Keywords: seed/ alders/ cold hardiness/ cold hardiness/ stress

429. Hall, R. B., and R. D. Hanna. 1995. Exchange, evaluation, and joint testing of genetic stock. Biomass and Bioenergy 9(15):81-87.

Keywords: Populus/ Melampsoral germplasm/ species selection

430. Hall, R. B., E. R. Hart, and C. S. Duncan. 1991. Screening Alnus for resistance to Fenusa dohrnii (Tischbein). pp. 116-125. In Proceedings: 1991 Joint Meeting of the Task V Activity Groups on Exchange of Genetic Material, Pest/Disease Management, and Joint Trials of Alnus, Populus, and Salix. Iowa State University Printing Service, Ames, Iowa.

Keywords: screening/ Alnus/ diseases/ Fenusa dohrnii/ hybrids

431. Hall, R. B., G. A. Miller, T. L. Robison, and O. U. Onokpise. 1983. Intensive Plantation Culture (12 Years Research). NC-91. U.S. Forest Service, North Central Forest Experiment Station, Duluth, Minnesota.

Keywords: Alnus

432. Hall, R. B., and R. N. Nyong'o. 1987. Design, establishment, and management of a black alder (Alnus glutinosa L. gaertn.) seed orchard. pp. 261268. In Proceedings, 19th Southern Forest Tree Improvement Conference. National Technical Information Service, Springfield, Virginia.

Keywords: breeding/ flowering/ coppice/ alders/ crop management

433. Hall, R. B., M. E. Ostry, and N. E. Nordh. 1994. IEA joint trials: New lessons from old plantations. Biomass and Bioenergy 2:85-94.

Keywords: poplars/ Salix/ Alnus/ yields/ diseases/ insects/ coppice 
434. Hall, R. B., M. Sabatti, G. E. Scarascia-Mugnozza, and N. Anselmi. 1993. Developing Populus alba improvement programs in Iowa and Italy. pp. 22-31. In Proceedings of the Second Northern Forest Genetics Association Conference. University of Minnesota, St. Paul, Minnesota.

Keywords: aspens/ breeding/ poplars/ clonal propagation

435. Hallam, J. A., I. C. Anderson, and D. R. Buxton. 2001. Comparative economic analysis of perennial, annual, and intercrops for biomass production. Biomass and Bioenergy 21:407-424.

Keywords: energy crops/ economics/ annuals/ perennials/ intercropping/ switchgrass/ Panicum virgatum/ big bluestem/ sorghum

436. Han, K.-H., H. D. Bradshaw, Jr., and M. P. Gordon. 1994. Adventitious root and shoot regeneration in vitro is under major gene control in an F2 family of hybrid poplar (Populus trichocarpa $\times$ P. deltoides). Forest Genetics 1(3):139-146.

Keywords: roots/ shoots/ in vitro culture/ genetics/ poplars, hybrid

437. Han, K.-H., M. P. Gordon, and S. H. Strauss. 1996. Cellular and molecular biology of Agrobacteriummediated transformation of plants and its application to genetic transformation of Populus. pp. 201-222. In Biology of Populus and its Implications for Management and Conservation. R. F. Stettler, Jr., H. D. Bradshaw, P. E. Heilman, and T. M. Hinckley (eds.). NRC Research Press, Ottawa, Ontario, Canada. Keywords: cellular biology/ molecular biology/agrobacterium/ transformation, mediated/ genetics/ Populus

438. Han, K.-H., M. P. Gordon, and S. H. Strauss. 1997. High-frequency transformation of cottonwoods (genus Populus) by Agrobacterium rhizogenes. Canadian Journal of Forest Research 27:464-470.
Keywords: cottonwoods/ Populus/ agrobacterium

439. Haney, R. L., A. J. Franzluebbers, F. M. Hons, and L. R. Hossner. 2001.

Molar concentration of $\mathrm{K}_{2} \mathrm{SO}_{4}$ and soil $\mathrm{pH}$ affect estimation of extractable $\mathrm{C}$ with chloroform fumigation-extraction. Soil Biology \& Biochemistry 33:1501-1507. Keywords: soil carbon

440. Haney, R. L., A. J. Franzluebbers, F. M. Hons, and D. A. Zuberer. 1999.

Soil C extracted with water or K2SO4: $\mathrm{pH}$ effect on determination of microbial biomass. Canadian J. Soil Science 79:529533.

Keywords: soils/ microbial biomass

441. Haney, R. L., F. M. Hons, A. J. Franzluebbers, and D. A. Zuberer. 1998. Daily carbon dioxide evolution from soils following chloroform fumigation. pp. 215. In Agronomy Abstracts.

Keywords: carbon dioxide/ soils/ chloroform fumigation

442. Hanover, J. W. 1980. Control of tree growth. BioScience 30:756-762.

Keywords: growth/ woody crops/ growth responses

443. Hanover, J. W. 1986. Agroforestry comes of age. Futures 4:12-15.

Keywords: agroforestry

444. Hanover, J. W. 1989. Physiological genetics of black locust (Robinia pseudoacacia L.): A model multipurpose tree species. pp. 9. In International Conference on Fast Growing Trees and Nitrogen Fixing Trees. Philipps University, Marbing, Germany.

Keywords: locusts, black/ Robinia pseudoacacia/ growth patterns/ composition

445. Hanover, J. W., and J. W. Hart. 1980. Greenhouse trees. Southern Florist and Nurseryman 93:20-21, 66-69.

Keywords: greenhouse 
446. Hanover, J. W., O. Okafo, J. C. Brissette, and J. W. Wright. 1980. A Directory of Forest Genetic Plantings in Michigan. Research Report 395. Michigan State University, Agricultural Experiment Station, East Lansing, Michigan. Keywords: genetics/ forests/ Michigan

447. Hanowski, J. M., G. J. Niemi, and D. C. Christian. 1997. Influence of withinplantation heterogeneity and surrounding landscape composition on Avian communities in hyrid poplar plantations. Conservation Biology 11(4):936-944. Keywords: heterogeneity/ landscapes/ birds/ poplars, hybrid

448. Hansen, E. A. 1981. Root length in young hybrid Populus plantations: Its implication for border width of research plots. Forest Science 27:808-814. Keywords: plot size/ border effects/ buffer strips/ experimental design/ poplars

449. Hansen, E. A. 1986 . Nutrient sources for fast growing forests: Principles, practices, and future directions. pp. 67-73. In Proceedings, IEA/BA Task II Workshop: Production Technology, Economics and Nutrient Cycling. ENFOR Secretariat, Canadian Forestry Service, Ottawa, Ontario, Canada.

Keywords: plantations/ intensive culture/ fertilization/ short rotation woody crops

450. Hansen, E. A. 1986. Planting date affects survival and height growth of hybrid poplar. The Forestry Chronicle 62:164-169. Keywords: poplars/ biomass crops/ establishment/ short rotation woody crops/ intensive culture

451. Hansen, E. A. 1987. Research strategy for attaining high yielding Populus energy plantations. pp. 121-132. In Proceedings, Energy from Biomass and Wastes X. D. L. Klass (ed.). Institute of Gas Technology, Chicago, Illinois. Keywords: poplars/ experimental design/ crop management
452. Hansen, E. A. 1988. Irrigating short rotation intensive culture hybrid poplars. Biomass 16:237-250.

Keywords: poplars/ biomass crops/ biomass crops/ soil properties/growth/ irrigation

453. Hansen, E. A. 1988. SRIC yields: A look to the future. pp. 197-207. In Proceedings, IEA/BA Task II Workshop: Economic Evaluations of Short-Rotation Biomass Energy Systems. Information Report 88:2. U.S. Forest Service, Forest Products Laboratory, Madison, Wisconsin. Keywords: yields/ biomass crops/ biomass crops/ short rotation woody crops

454. Hansen, E. A. 1990. Early Yields of Biomass Plantations in North Central U.S. NC-353. U.S. Forest Service, North Central Forest Experiment Station, Rhinelander, Wisconsin.

Keywords: short rotation intensive culture/ biomass crops/ poplars, hybrid/ yields/ growth/ productivity

455. Hansen, E. A. 1991. Energy plantations in North Central United States: Status of research and development plantations. Energy Sources 13:105-110. Keywords: short rotation woody crops/ poplars, hybrid/ short rotation intensive culture/ plantations

456. Hansen, E. A. 1991. Poplar woody biomass yields: Look to the future. Biomass and Bioenergy 1:1-7.

Keywords: biomass crops/ economics/ biomass crops

457. Hansen, E. A. 1992. Biological opportunities to increase tree biomass accumulation and yield from timberland. pp. 104-114. In Proceedings, Forest in a Changing Climate - North American Conference on Forestry Responses to Climate Change. A. Qureshi (ed.). Climate Institute.

Keywords: biomass/ timber/ forests/ climate/ productivity 
458. Hansen, E. A. 1992. Mid-Rotation Yields of Biomass Plantations in the North Central United States. NC-309. U.S. Forest Service, North Central Forest Experiment Station, St. Paul, Minnesota.

Keywords: intensive culture/ biomass crops/ poplars, hybrid/ hybrids/ short rotation woody crops/ yields/ survival rate

459. Hansen, E. A. 1993. Soil carbon sequestration beneath hybrid poplar plantations in the north central United States. Biomass and Bioenergy 5:431-436. Keywords: soils/ carbon sequestration/ poplars, hybrid/ biomass crops/ biomass crops/ wood

460. Hansen, E. A. 1994. A Guide for Determining When to Fertilize Hybrid Poplar Plantations. Research Paper NC-319. U.S. Department of Agriculture, Forest Service, St. Paul, Minnesota. Keywords: fertilization/ poplars, hybrid/ crop management

461. Hansen, E. A., and J. B. Baker. 1979. Biomass and nutrient removal in short rotation intensively cultured plantations. pp. 130-151. In Proceedings, Symposium on Impact of Intensive Harvesting on Forest Nutrient Recycling. State University of New York, Syracuse, New York.

Keywords: dry matter/ coppice/ biomass crops/ poplars/ Platanus/ clonal propagation/ nutrient cycling

462. Hansen, E. A., D. H. Dawson, and D. N. Tolsted. 1980. Irrigation of intensively cultured plantations with paper mill effluent. TAPPI 63:5.

Keywords: effluents/ forestry/ short rotation woody crops/ plantations/ irrigation/ poplars

463. Hansen, E. A., and J. O. Dawson. 1982. Effects of Alnus glutinosa on hybrid Populus height growth in a short-rotation intensively cultured plantation. Forest Science 28:49-59.

Keywords: Alnus glutinosal Populus
464. Hansen, E. A., and R. E. Dickson. 1979. Water and mineral nutrient transfer between root systems of juvenile Populus. Forest Science 25:247-252.

Keywords: nitrogen/ potassium/ tritiated water/ roots/ grafting/ Populus/ nutrients

465. Hansen, E. A., P. E. Heilman, and S. Stroble. 1990. Clonal testing and selection for field plantations. pp. 124-145. In Ecophysiology of Short Rotation Forest Crops, Chapter 5. C. P. Mitchell, J. B. Ford-Robertson, T. M. Hinckley, and L. Sennerby-Forsse (eds.). Elsevier Science Publishers Ltd., New York.

Keywords: clonal propagation/ poplars, hybrid/ yields/ North America

466. Hansen, E. A., and H. A. I.

Madgwick. 1985. Short-rotation plantation management for coniferous species. pp. 212-229. In Proceedings, Research in Forestry for Energy. Intern Stencil nr 37/1985. Swedish University of Agricultural Sciences, Department of Operational Efficiency, Garpenburg, Sweden.

Keywords: pines/ larches/ crop management/ conifers/ short rotation woody crops

467. Hansen, E. A., and H. A. I. Madgwick. 1986. Short-rotation plantation management technology for coniferous species. pp. 212-228. In Proceedings of the Joint International Energy Agency/Forestry Energy Programme and Food and Agricultural Organization/Cooperative Network on Rural Energy Forest Energy Conference and Workshops on Research in Forestry for Energy. C. P. Mitchell, P. O. Nilsson, and L. Zsuffa (eds.). Swedish University of Agricultural Sciences, Rungstedghaard, Denmark. Keywords: conifers/ short rotation woody crops/ crop management/ intensive culture

468. Hansen, E. A., R. A. McLaughlin, and P. E. Pope. 1988. Biomass and nitrogen dynamics of hybrid poplar on two different soils: Implications for fertilization 
strategy. Canadian Journal of Forest

Research 18:223-230.

Keywords: poplars/ fertilization/ nitrogen

469. Hansen, E. A., H. A. McNeel, D. A. Netzer, H. M. Phipps, P. S. Roberts, T. F. Strong, D. N. Tolsted, and J. Zavitkovski. 1979. Short-rotation intensive culture practices for northern Wisconsin. pp. 47-63. In Proceedings, 16th Annual Meeting, North American Poplar Council, Joint Meeting of the United States and the Canadian Chapters. North American Poplar Council, Filer City, Michigan.

Keywords: short rotation intensive culture/ poplars, hybrid/ site preparation/ irrigation/ Wisconsin/ poplars

470. Hansen, E. A., and M. J. Morin. 1983. Short rotation plantation tending: Biological needs and mechanization. pp. 37-42. In Short Rotation Forest Biomass Production Technology and Mechanization. P. O. Nilsson and L. Zsuffa (eds.). Internal Rep. No. 229. Swedish University of Agricultural Sciences, Department of Operational Efficiency, Garpenburg, Sweden.

Keywords: crop management/ short rotation woody crops

471. Hansen, E. A., and D. A. Netzer. 1984. Geese, grass, and trees. Tree Planters' Notes 35:10-11.

Keywords: biomass resources/ energy crops

472. Hansen, E. A., and D. A. Netzer. 1985. Weed Control Using Herbicides in Short-Rotation Intensively Cultured Poplar Plantations. NC-260. U.S. Forest Service, North Central Forest Experiment Station, St. Paul, Minnesota.

Keywords: poplars/ competition/ linuron/ glyphosate/ weed control

473. Hansen, E. A., and D. A. Netzer. 1986. Hybrid Poplar Stool Spacing: Effects on Hardwood Cutting Production. NC-278. U.S. Forest Service, North Central Forest Experiment Station, St. Paul, Minnesota.
Keywords: nursery, forest/ clonal orchards/ cuttings/ short rotation woody crops/ poplars

474. Hansen, E. A., D. A. Netzer, and W. J. Rietveld. 1984. Site Preparation for Intensively Cultured Hybrid Poplar Plantations. NC-320. U.S. Forest Service, North Central Forest Experiment Station, St. Paul, Minnesota.

Keywords: short rotation intensive culture/ weed control/ glyphosate/ linuron/ no-till/ fallowing/ establishment/ poplars, hybrid

475. Hansen, E. A., D. A. Netzer, and W. J. Rietveld. 1984. Weed Control for Establishing Intensively Cultured Hybrid Poplar Plantations. NC-317. U.S. Forest Service, North Central Forest Experiment Station, Rhinelander, Wisconsin.

Keywords: poplars/ short rotation intensive culture/ establishment/ cultural practices/ nitrogen fixation/ weed control

476. Hansen, E. A., D. A. Netzer, and D. N. Tolsted. 1993. Guidelines for Establishing Poplar Plantations in the NorthCentral U.S. NC-363. U.S. Forest Service, North Central Forest Experiment Station, St. Paul, Minnesota.

Keywords: poplars, hybrid/ plantations/ short rotation woody crops/ biomass crops

477. Hansen, E. A., D. A. Netzer, and R. F. Woods. 1986. Tillage superior to notill for establishing hybrid poplar plantations. Tree Planters' Notes 37:6-10. Keywords: poplars/ establishment/ cultural practices/ no-till

478. Hansen, E. A., M. E. Ostry, W. D. Johnson, D. N. Tolsted, D. A. Netzer, W. E. Berguson, and R. B. Hall. 1994. Field Performance of Populus in ShortRotation Intensive Culture Plantations in the North-Central U.S. NC-320. U.S. Forest Service, North Central Forest Experiment Station, St. Paul, Minnesota.

Keywords: short rotation intensive culture/ energy crops/ genetic selection/ poplars, hybrid/ diseases 
479. Hansen, E. A., M. E. Ostry, D. A. Netzer, and D. N. Tolsted. 1994. Short Rotation Woody Crop Trials for Energy Production in North Central U.S. ORNL/M5058. Oak Ridge National Laboratory, Oak Ridge, Tennessee.

Keywords: short rotation woody crops/ energy/ northcentral states/ species selection

480. Hansen, E. A., and H. M. Phipps. 1981. How to Grow Hybrid Poplars. NC49. U.S. Forest Service, North Central Forest Experiment Station, Rhineland, Wisconsin.

Keywords: poplars, hybrid/ establishment/ crop management

481. Hansen, E. A., and H. M. Phipps. 1983. Effect of soil moisture tension and preplant treatments on early growth of hybrid Populus hardwood cuttings. Canadian Journal of Forest Research 13:458-464.

Keywords: Populus/ soil properties/ pretreatments/ establishment

482. Hansen, E. A., H. M. Phipps, and D. N. Tolsted. 1979. Rooting greenwood tip cuttings of a difficult-to-root Populus clone. Tree Planters' Notes 30:9-11. Keywords: poplars/ hybrids/ clonal propagation/ roots

483. Hansen, E. A., and D. N. Tolsted. 1981. Effects of cutting diameter and stem or branch position on establishment of a difficult-to-root clone of a Populus alba hybrid. Canadian Journal of Forest Research 11:723-727.

Keywords: harvesting/ clonal propagation/ Populus/ establishment

484. Hansen, E. A., and D. N. Tolsted. 1985. Nitrogen sources and fertilizer rates affect growth of hybrid poplar. pp. 71-77. In Proceedings, Fifth Central Hardwood Forest Conference. J. O. Dawson and K. A. Majerus (eds.). University of Illinois, Department of Forestry, UrbanaChampaign, Illinois.
Keywords: nitrogen/ fertilization/ poplars, hybrid

485. Hansen, E. A., D. N. Tolsted, and M. Tower. 1991. Planting Depth of Hybrid Poplar Cuttings Influences Number of Shoots. NC-355. U.S. Forest Service, North Central Forest Experiment Station, St. Paul, Minnesota.

Keywords: multiple shoots/ stems/ short rotation intensive culture/ biomass crops/ poplars, hybrid/ establishment

486. Hansen, P. H., R. E. McRoberts, J. G. Isebrands, and R. K. Dixon. 1985. An optimum sampling strategy for measuring $\mathrm{CO}_{2}$ rates. Plant Physiology (Suppl.) 77:40.

Keywords: experimental design/ carbon dioxide

487. Hansen, P. H., R. E. McRoberts, J. G. Isebrands, and R. K. Dixon. 1987. Determining $\mathrm{CO}_{2}$ exchange rate as a function of photosynthetic photon flux density. Photosynthetica 21:98-101. Keywords: photosynthesis/ carbon dioxide

488. Harmoney, K. R., K. J. Moore, J. R. George, E. C. Brummer, and J. R. Russell. 1997. Determination of pasture biomass using four indirect methods. Agronomy Journal 89(4):665-672.

Keywords: biomass crops/ pasture

489. Harms, W. R., D. S. DeBell, and C. D. Whitesell. 1994. Stand and tree characteristics and stockability in Pinus taeda plantations in Hawaii and South Carolina. pp. 511. In Canadian Journal of Forestry Research.

Keywords: Pinus taeda/ Hawaii/ South Carolina

490. Harrell, M. O. , D. M. Benjamin, J. G. Berbee, and T. R. Burkot. 1981. Evaluation of adult cottonwood leaf beetle, Chrysomela scripta (Coleoptera: Chrysomelidae), feeding preference for hybrid poplars. Great Lakes Entomology 14:181-184. 
Keywords: Chrysomela scriptal Populus/ pests

491. Harrell, M. O. , D. M. Benjamin, J. G. Berbee, and T. R. Burkot. 1982.

Consumption and utilization of leaf tissuecultured Populus $\times$ Euramericana by the cottonwood leaf beetle, Chrysomela scripta (Coleoptera: Chrysomelidae). Canadian

Entomology 144:743-749.

Keywords: Populus Euramericanal Chrysomela scriptal pests

492. Harrington, C. A. 1983 . Silviculture of western hardwoods. pp. 28-32. In Proceedings, 1982 Convention of the Society of American Foresters. SAF Publ. 83-04. Society of American Foresters, Bethesda, Maryland.

Keywords: silviculture/ hardwoods

493. Harrington, C. A. 1984 . Factors influencing initial sprouting of red alder. Canadian Journal of Forest Research 14:357-361.

Keywords: sprouting/ Alnus rubral stump height/ alders

494. Harrington, C. A. 1984 . Site quality prediction for red alder. Agronomy Abstracts p. 260.

Keywords: site characteristics/alders

495. Harrington, C. A. 1986. A Method of Site Quality Evaluation for Red Alder. PNW-192. U.S. Forest Service, Pacific Northwest Research Station, Portland, Oregon.

Keywords: site characteristics/models/ alders/ Alnus rubra

496. Harrington, C. A., and R. O. Curtis. 1986. Height Growth and Site Index Curves for Red Alder. PNW-358. U.S. Forest Service, Pacific Northwest Research Station, Portland, Oregon.

Keywords: growth/ site characteristics/ alders/ Alnus rubra

497. Harrington, C. A., and D. S. DeBell. 1980. Variation in specific gravity of red alder (Alnus rubra Bong.). Canadian Journal of Forest Research 10:293-299. Keywords: alders/ Alnus rubra/ silviculture/ growth patterns

498. Harrington, C. A., and D. S. DeBell. 1983. Effects of irrigation, pulp mill sludge, and repeated coppicing on growth and yield of black cottonwood and red alder.

Canadian Journal of Forest Research 14:844-849.

Keywords: Populus trichocarpal Alnus rubra/ harvesting/ irrigation/sludge/ coppice

499. Harry, D. E., and R. R. Sederoff. 1989. Biotechnology in Biomass Crop Production: The Relationship of Biomass Production and Plant Genetic Engineering. ORNL/M-978. Oak Ridge National Laboratory, Oak Ridge, Tennessee. Keywords: tissue culture/ regeneration/ genetic modification/ growth patterns/ environmental effects

500. Hart, E. R., R. B. Hall, and R. D. Hanna. 1991. Dispersal of Fenusa dohrnii (Hymenoptera: Tenthredenidae) from an Alnus short-rotation forest plantation. The Great Lakes Entomologist 24:63-68.

Keywords: leafminer, European alders/ Fenusa dohrnii/ insects/ pests/ short rotation woody crops/ plantations

501. Hart, E. R., H. S. McNabb, Jr., and R. B. Hall. 1992. The role of host genetics in the biological control of forest insect pests. pp. 94-101. In Proceedings of the 44th Annual Meeting - Biological Control of Forest Pests in the Great Plains: Status and Needs. Publication No. 145. Great Plains Agricultural Council, N.p.

Keywords: host-pathogen/ biological control/ insects/ biomass crops/ poplars

502. Hart, E. R., D. G. Petty, R. B. Hall, D. A. Herms, R. D. Hanna, and J. N. Kean. 1991. Activity of Fenusa dohrnii (Hymenoptera: Tenthredenidae) on Alnus in the north central United States. Environmental Entomology 20:534-539. 
Keywords: insects/ phenology/ Fenusa dohrniil Alnus/ Fenusa dohrnii

503. Heebner, C. F., and M. J. Bergener. 1983. Red Alder: A Bibliography with Abstracts. PNW-161. U.S. Forest Service, Pacific Northwest Forest and Range Experiment Station, Portland, Oregon. Keywords: alders/ Alnus rubra

504. Heilman, P. E. 1979. Use of alder in coal spoil reclamation in the Pacific Northwest. pp. 477. In Symbiotic Nitrogen Fixation in the Management of Temperate Forests. J. C. Gordon, C. T. Wheeler, and D. A. Perry (eds.). Oregon State University, Forest Research Laboratory, Corvallis, Oregon.

Keywords: alders/ coal spoils/ reclamation

505. Heilman, P. E. 1981. Benefits of wood biomass make cultivation essential. Weeds, Trees and Turf 20:38-40.

Keywords: wood biomass/ cultural practices

506. Heilman, P. E. 1982 . Nitrogen and organic matter accumulation in coal mine spoils supporting red alder stands.

Canadian Journal of Forest Research 12 :809-813.

Keywords: alders/ coal spoils/ nitrogen/ organic matter/ reclamation

507. Heilman, P. E. 1982. Nodulation and nitrogen fixation by red alder and sitka alder on coal mine spoils. Canadian Journal of Forest Research 12:991-997.

Keywords: alders/ alders/ coal spoils/ nitrogen fixation/ nodulation/ reclamation

508. Heilman, P. E. 1985. Sampling and genetic variation of foliar nitrogen in black cottonwood and its hybrids in short rotation. Canadian Journal of Forest Research 15:1137-1141.

Keywords: nitrogen/ cottonwoods/ hybrids/ short rotation woody crops

509. Heilman, P. E. 1986. Research and development and operational forest fertilization, northwest United States. pp. 129-138. In Proceedings, IEA/BA Task II Workshop: Production Technology, Economics and Nutrient Cycling. ENFOR Secretariat, Ottawa, Ontario, Canada. Keywords: fertilization/ forests/ crop management

510. Heilman, P. E. 1988. A new beginning in forestry: High yield plantations. Washington Lands and People 2:8-12.

Keywords: forestry/ crop management

511. Heilman, P. E. 1990. Growth of Douglas fir and red alder on coal spoils in western Washington. Soil Science Society of America Journal 54:522-527.

Keywords: fir/ alders/ coal spoils/ Washington/ fertilization/ restoration

512. Heilman, P. E. 1992. Sustaining production: Nutrient dynamics and soils. pp. 216-230. In Ecophysiology of Short Rotation Forest Crops. C. P. Mitchell, J. B. Ford-Robertson, T. M. Hinckley, and L. Sennerby-Forsse (eds.). Elsevier Science Publishers Ltd., New York.

Keywords: production/ nutrients/ soils/ forestry/ environmental effects

513. Heilman, P. E., and G. Ekuan. 1979. Effect of planting stock length and spacing on growth of black cottonwood. Forest Science 25:439-443.

Keywords: poplars/ Populus trichocarpal establishment/ tree quality/ bole crookedness

514. Heilman, P. E. , G. Ekuan, and D. B. Fogle. 1994. Above- and belowground biomass and fine roots of four-yearold hybrids of Populus trichocarpa $\times$ $P$. deltoides and parental species in short rotation culture. Canadian Journal of Forest Research 24(6):1186-1192. Keywords: biomass crops/ roots/ hybrids/ Populus trichocarpa/ Populus deltoides/ short rotation intensive culture

515. Heilman, P. E. , G. Ekuan, and D. B. Fogle. 1994. First-order root 
development from cuttings of Populus trichocarpa $\times P$. deltoides hybrids. Tree Physiology 14:911-920.

Keywords: roots/ poplars/ Populus/ propagation

516. Heilman, P. E., and X. Fu-Guang. 1993. Influence of nitrogen on growth and productivity of short-rotation Populus trichocarpa $\times$ Populus deltoides hybrids. Canadian Journal of Forest Research 23:1863-1869.

Keywords: nitrogen/ growth/ productivity/ Populus trichocarpal Populus deltoides/ hybrids/ short rotation woody crops

517. Heilman, P. E., and X. Fu-Guang. 1994. Effects of nitrogen fertilization on leaf area, light interception and productivity of short rotation Populus trichocarpa $\times$ Populus deltoides hybrids. Canadian Journal of Forest Research 24(1):166-173. Keywords: nitrogen/ fertilization/ leaf area/ light/ productivity/ short rotation woody crops/ poplars/ hybrids

518. Heilman, P. E. , T. M. Hinckley, D. A. Roberts, and R. J. Ceulemans. 1996. Production physiology. pp. 459-490. In Biology of Populus and Its Implications for Management and Conservation. R. F. Stettler, Jr., H. D. Bradshaw, P. E. Heilman, and T. M. Hinckley (eds.). NRC Research Press, Ottawa, Canada. Keywords: ecology/ conservation/ cottonwoods/ Populus/ physiology

519. Heilman, P. E., and D. V. Peabody, Jr. 1981. Effect of harvest cycle and spacing on productivity of black cottonwood in intensive culture. Canadian Journal of Forest Research 11:118-123.

Keywords: coppice/ poplars/ productivity/ harvest cycles/ stand density

520. Heilman, P. E., and R. F. Stettler. 1983. Phytomass production in young mixed plantations of Alnus rubra Bong. and cottonwood in western Washington. Canadian Journal of Microbiology 19:10071013.
Keywords: Alnus rubra/ cottonwoods/ biomass crops

521. Heilman, P. E., and R. F. Stettler. 1985. Mixed, short-rotation culture of red alder and black cottonwood: Growth, coppicing, nitrogen fixation and allelopathy. Forest Science 31:607-616.

Keywords: alders/ cottonwoods/ nitrogen fixation/growth/ allelopathic effects

522. Heilman, P. E., and R. F. Stettler. 1986. Nutritional concerns in selection of black cottonwood and hybrid clones for short rotation. Canadian Journal of Forest Research 16:860-863.

Keywords: cottonwoods/ species selection/ nutrients

523. Heilman, P. E., and R. F. Stettler. 1990. Genetic variation and productivity of Populus trichocarpa and its hybrids. IV. Performance in short-rotation coppice. Canadian Journal of Forest Research 20:1257-1264.

Keywords: sprouting/ growth/ yields/ Populus trichocarpa/ coppice/ genetic variations

524. Heilman, P. E., R. F. Stettler, D. P. Hanley, and R. W. Carkner. 1990. High Yield Hybrid Poplar Plantations in the Pacific Northwest. PNW356. U.S. Forest Service, Pacific Northwest Research Station, Portland, Oregon.

Keywords: poplars/ crop management/ harvesting

525. Herms, D. A., W. J. Mattson, D. N. Karowe, M. D. Coleman, T. M. Trier, B. A. Birr, and J. G. Isebrands. 1996. Proceedings, 1995 Meeting of the Northern Global Change Program. NE-214. J. Hom, R. Birdsey, and K. O'Brian (eds.). USDA Forest Service, Radnor, Pennsylvania. Keywords: aspens/ clones/ carbon dioxide/ ozone/ Populus/ growth

526. Heuchelin, S. A., L. Jouanin, N. B. Klopfenstein, and H. S. McNabb, Jr. 1997. Micropropagation, Genetic 
Engineering, and Molecular Biology of Populus. RM-GTR-297. US Forest Service, Fort Collins, Colorado. Keywords: proteinase inhibitors/ Populus/ arthropod/ pathogens

527. Heuchelin, S. A., H. S. McNabb, Jr., and N. B. Klopfenstein. 1997.

Agrobacterium mediated transformation of

Populus $\times$ Euramericana 'Ogy' using chimeric CaMV 35S - pin2 gene fusion. Canadian Journal of Forest Research 27:1041-1048.

Keywords: agrobacterium/ genetic modification/ poplars, hybrid/ proteinase inhibitors/genes

528. Hilu, K. W., S. Boyd, and P. Felker. 1982. Morphological diversity and taxonomy of California mesquites (Prosopis, Leguminosae). Madrono 29:237254.

Keywords: mesquite/ Prosopis/ morphology/ taxonomy

529. Hinckley, T. M. 1997. Direct and indirect human impacts on forests and forest ecosystems. pp. 5-7. In Proceedings of the Korean Forestry Society Meetings.

Keywords: forests

530. Hinckley, T. M., and J. H. Braatne. 1994. Stomata. pp. 323-355. In Plant-

Environment Interactions. R. E. Wilkinson (ed.). Marcel Dekker, Inc., New York.

Keywords: stomata

531. Hinckley, T. M., J. H. Braatne, R. J. Ceulemans, P. Clum, J. M. Dunlap, D. Newman, B. Smith, G. E. ScarasciaMugnozza, and E. Van Volkenburgh. 1992. Growth dynamics and canopy structure. pp. 1-34. In Ecophysiology of Short Rotation Forest Crops. C. P. Mitchell, J. B. Ford-Robertson, T. M. Hinckley, and L. Sennerby-Forsse (eds.). Elsevier Science Publishers Ltd., New York. Keywords: growth patterns/ crown architecture/ physiology/ morphology/ genetics
532. Hinckley, T. M., J. R. Brooks, J. Cermak, R. J. Ceulemans, J. Kucera, F. C. Meinzer, D. A. Roberts, and M. Wampler. 1993. Canopy Coupling to the Atmosphere: An Examination of Water Exchange in a Hybrid Poplar Stand. pp. 161-162. In Ecophysiology and Genetics of Trees in a Changing Environment. G. E. Scarascia-Mugnozza and R. Valentini (eds.). Viterbo, Italy.

Keywords: canopy/ atmosphere/ water relations/ poplars, hybrid

533. Hinckley, T. M., and R. J. Ceulemans. 1989. Current focuses in woody plant water relations and drought resistance. Annales Des Sciences Forestieres 46:515s-518s.

Keywords: drought/ stomata/ water relations/ woody crops

534. Hinckley, T. M., R. J. Ceulemans, J. M. Dunlap, A. L. Figliola, P. E. Heilman, J. G. Isebrands, G. E. Scarascia-Mugnozza, P. J. Schulte, B. Smith, R. F. Stettler, E. Van Volkenburgh, and B. M. Wiard. 1989. Physiological, morphological and anatomical components of hybrid vigor in Populus. pp. 199-217. In Structural and Functional Responses to Environmental Stresses. K. H. Kreeb, H. Richter, and T. M. Hinckley (eds.). SPB Academic Publishing bv, The Hague, The Netherlands. Keywords: stomata/ turgor/ crown architecture/ photosynthesis/ carbon/ Populus/ hybrids

535. Hinckley, T. M., H. Richter, and P. J. Schulte. 1991. Water relations. pp. 137-162. In Physiology of Trees. A. S. Raghavendra (ed.). John Wiley \& Sons, Inc., New York.

Keywords: water relations/ water relations/ stress/ water relations/ transpiration/ drought

536. Hines, D. J., and M. E. Downing. 1997. Bioenergy education and information: A framework for a comprehensive education effort. pp. 295. In Third Biomass Conference of the Americas: Energy, 
Environment, Agriculture, and Industry.

Elsevier.

Keywords: bioenergy/ education

537. Hines, D. J., and M. E. Downing. 1997. Market development for bioenergy: The role of targeted communications. pp. 1481. In Third Biomass Conference of the Americas: Energy, Environment, Agriculture, and Industry. Elsevier. Keywords: bioenergy/ markets

538. Hintz, R. L., K. R. Harmoney, K. J. Moore, J. R. George, and E. C. Brummer. 1998. Establishment of switchgrass and big bluestem in corn with atrazine. Agronomy Journal 90(5):591-596.

Keywords: switchgrass/ Panicum virgatum/ big bluestem/ corn/ atrazine

539. Hodges, J. W. 1986. The Short Rotation Woody Crops Program Computerized Technical Data Base System. ORNL/TM-9959. Oak Ridge National Laboratory, Oak Ridge, Tennessee. Keywords: short rotation woody crops/ information resources

540. Hohenstein, W. G., and L. L. Wright. 1994. Biomass energy production in the United States: An overview. Biomass and Bioenergy 6(3):161-173.

Keywords: biomass crops/ energy crops, herbaceous/ short rotation woody crops/ environmental effects/ economics/ feedstocks

541. Hokans, R. H., and W. B. Stuart. 1983. Yard-to-mill woodflow scheduling by microcomputer. Southern Journal of Applied Forestry 7:50-53.

Keywords: feedstocks/ forest products/ processing

542. Holt, K. E., H. S. McNabb, Jr., M. A. Rothlauf, F. G. Manwiller, and M. E. Ostry. 1981. Characteristics of kraft paper made from Septoria cankered Populus grown under short-rotation, intensive culture. Phytopathology 1:226.

Keywords: Septorial Populus/ paper
543. Hons, F. M., R. F. Moresco, R. P. Wiedenfeld, and J. T. Cothren. 1986. Applied nitrogen and phosphorus effects on yield and nutrient uptake by high-energy sorghum produced for grain and biomass. Agronomy Journal 78(6):1069-1078. Keywords: nutrients/ plant characteristics/ Sorghum bicolor/ nitrogen/ phosphorus/ grains/ biomass crops

544. Hook, D. D., D. S. DeBell, A. Ager, and D. W. Johnson. 1989. Dry weight partitioning among 36 open-pollinated red alder families. Biomass 21:11-25.

Keywords: Alnus/ growth/ leaf area/ leaf development/ elevation/ drainage system/ harvest index

545. Hook, D. D., M. D. Murray, D. S. DeBell, and B. C. Wilson. 1987. Variation in growth of red alder families in relation to shallow water table levels. Forest Science 33:224-229.

Keywords: Alnus rubra/ waterlogged soils/ genetic variations/ soils/ waterlogging/ growth/ water availability

546. Hooper, C., M. F. Bolin, J. J. Jokela, G. L. Rolfe, and T. A. White. 1985.

Fuelwood Plantations. Circular 1236.

University of Illinois, College of

Agriculture, Cooperative Extension Service, Urbana-Champaign, Illinois.

Keywords: fuelwood/ crop management

547. Hopkins, A. A. , C. M. Taliaferro, C. D. Murphy, and D. Christian. 1996. Chromosome Number and Nuclear DNA Content of Several Switchgrass Populations. Crop Science 36(5):1192-1995.

Keywords: switchgrass/ Panicum virgatum/ DNA/ molecular genetics

548. Hopkins, A. A., K. P. Vogel, K. J. Moore, K. D. Johnson, and I. T. Carlson. 1993. Genotype and genotype $x$ environment interaction effects on forage yield of switchgrass in the midwestern states. pp. 184-219. In 1993 American Forage and Grassland Council Proceedings, 'The Dollar \& Sense of 
Forages.' American Forage and Grassland Council, Iowa Forage and Grassland Council, Des Moines, Iowa.

Keywords: genotypes/ environmental effects/ forage crops/ switchgrass/ Panicum virgatum/ biomass crops

549. Hopkins, A. A. , K. P. Vogel, K. J. Moore, K. D. Johnson, and I. T. Carlson. 1995. Plant genetic resources, genotypic variability and genotype $\times$ environment interactions among switchgrass accessions from the Midwestern USA. Crop Science 35:565-571.

Keywords: genetics/ genotypes/ environment/ switchgrass/ Panicum virgatum

550. Hopkins, A. A. , K. P. Vogel, K. J. Morre, K. D. Johnson, and I. T. Carlson. 1995. Genotype effects and genotype by environment interactions for traits of elite switchgrass populations. Crop Science 35(1):125-132.

Keywords: genotypes/ switchgrass/ Panicum virgatum/ GXE interaction/ genetic modification

551. Horwath, W. R. , E. A. Paul, and K. S. Pregitzer. 1992. Injection of nitrogen-15 into trees to study nitrogen cycling in soil (abstract). Soil Science Society of America Journal 56(1): No page numbers identified.

Keywords: nitrogen/ nitrogen

552. Hosier, M. A., S. Garton, P. E. Read, and R. S. Farnham. 1981. In vitro propagation of Alnus glutinosa. Journal of Horticultural Science 16:758-759.

Keywords: Alnus glutinosa/ clonal propagation

553. Host, G. E. 1991. An

ecophysiological whole tree approach to modelling tree growth. pp. 15-21. In

Forestry Canada Modeling Working Group,

Proceedings of the Fifth Modeling

Workshop. Forestry Canada, Alberta, Canada.

Keywords: ecophysiology/ models/ growth/ models/ carbon/ carbohydrates/ ecosystems/ models, ECOPHYS/ poplars

554. Host, G. E., and J. G. Isebrands. 1994. An interregional validation of ECOPHYS, a growth process model of juvenile poplar clones. Tree Physiology 14:933-945.

Keywords: photosynthesis/ poplars/ short rotation woody crops/models/ models, ECOPHYS

555. Host, G. E., and J. G. Isebrands. 1997. Modeling the Effects of Climatic Extremes on Early Growth of Poplar Under Short Rotation Intensive Culture. NC-196. USDA Forest Service - North Central, St. Paul, Minnesota.

Keywords: global change/ climate/ temperature/ light/ Populus/ modeling

556. Host, G. E., J. G. Isebrands, and K. Perttu. 1996. Modeling short rotation forestry growth: An international workshop. Biomass and Bioenergy 11(2/3):73-74.

Keywords: modeling/ Salix/ short rotation woody crops/ Sweden/ willows

557. Host, G. E., J. G. Isebrands, G. W. Theseira, J. R. Kiniry, and R. L. Graham. 1996. Temporal and spatial scaling from individual trees to plantations: A modeling strategy. Biomass and Bioenergy 11(2/3):233-243.

Keywords: short-rotation woody crops/ poplars/ plantations/ models/ scaling

558. Host, G. E., and H. M. Rauscher. 1990. Validating the regional applicability of a whole-plant ecophysiological growth process model of juvenile poplar. pp. 97-

106. In Proceedings of the IUFRO Conference, Forest Simulation Systems. L. C. Wensel and G. S. Biging (eds.). Bulletin 1927. University of California, Berkeley, California.

Keywords: models/ poplars/ photosynthesis

559. Host, G. E., H. M. Rauscher, J. G. Isebrands, D. I. Dickmann, R. E. Dickson, T. R. Crow, and D. A. Michael. 1990. 
The Microcomputer Scientific Series \#6:

The ECOPHYS User's Manual. NC-141. U.S. Forest Service, North Central Forest Experiment Station, St. Paul, Minnesota. Keywords: poplars/ whole-tree/ short rotation intensive culture/ photosynthesis/ carbon/ models, ECOPHYS

560. Host, G. E., H. M. Rauscher, J. G. Isebrands, and D. A. Michael. 1989.

Validation of the photosynthate production submodel of ECOPHYS, an

ecophysiological growth process model of Populus. In ECOPHYS: Dynamics of Ecophysiological Processess in Tree Crowns and Forest Canopies, International Workshop. U.S. Forest Service, North Central Forest Experiment Station, Rhinelander, Wisconsin.

Keywords: models/ light/ temperature/ leaf development/ models, ECOPHYS

561. Host, G. E., H. M. Rauscher, J. G. Isebrands, and D. A. Michael. 1990.

Validation of photosynthate production in ECOPHYS, an ecophysiological growth process model of Populus. Tree Physiology 7:283-296.

Keywords: poplars/ models/ leaf area/ photosynthesis/ models, ECOPHYS

562. Host, G. E., G. W. Theseira, and J. G. Isebrands. 1995. Mechanistic modeling of interactive stress effects in Populus. pp. 79. In Booklet of Abstracts: Dynamics of Physiological Processes in Woody Roots. M. A. Topa, P. T. Rygiewicz, and J. R. Cumming (eds.). Boyce Thompson Institute for Plant Research, Ithaca, New York. Keywords: modeling/ stress/ Populus/ ozone/ carbon dioxide/ climate/ forests/ ecosystems

563. Host, G. E., G. W. Theseira, and J. G. Isebrands. 1996. Modeling impacts of $\mathrm{CO}_{2}$, ozone, and climate change on tree growth. pp. 33-37. In 1995 Meeting of the Northern Global Change Program. NE214. USDA Forest Service, Radnor, Pennsylvania.
Keywords: modeling/ carbon dioxide/ ozone/ climate/ growth, forest/ poplars

564. Howe, G. T., J. M. Davis, Z. Jeknic, T. H. Chen, B. E. Frewen, H. D.

Bradshaw, Jr., and P. Saruul. 1999.

Physiological and genetic approaches to studying endodormancy-related traits in Populus. HortScience 34(7):1174-1184. Keywords: physiology/genetics/ Populus

565. Huetteman, C. A., J. E. Preece, W. C. Ashby, and P. L. Roth. 1992. Firstyear field performance of 60 micropropagated silver maple clones in southern Illinois. HortScience [89th Annual Meeting of the American Society for Horticultural Science] 27:228.

Keywords: clonal propagation/ maples, silver/ tissue culture/ Illinois/ plastic mulch/ drought/ irrigation/ erosion/ weeds

566. Huff, D. D., B. Hargrove, M. L. Tharp, and R. L. Graham. 2000.

Managing Forests for Water Yield, the Importance of Scale. Journal of Forestry 98(12):15-19.

Keywords: forests/ scale

567. Huffman, J. B. 1981. Wood and bark utilization research: A progress report. pp. 37-68. In Proceedings, Melaleuca Symposium. R. K. Gieger (ed.). Florida Division of Forestry, Tallahassee, Florida. Keywords: Melaleuca/ wood production

568. Huffman, J. B., and S. Wang. 1980. Heat of combustion of Melaleuca biomass. Forest Products Research Society Abstracts 34:24.

Keywords: Melaleuca/ conversion technologies

569. Hultquist, S. J., K. P. Vogel, D. J. Lee, K. Arumuganathan, and S. M. Kaeppler. 1996. Chloroplast DNA and nuclear DNA content variations among cultivars of switchgrass, Panicum virgatum L. Crop Science 36(4):1049-1052.

Keywords: switchgrass/ Panicum virgatum/ DNA 
570. Hultquist, S. J., K. P. Vogel, D. J. Lee, K. Arumuganathan, and S. M. Kaeppler. 1997. DNA content and chloroplast DNA polymorphisms among switchgrass from remnant midwestern prairies. Crop Science 37(2):

Keywords: DNA/ chloroplast/ switchgrass/ Panicum virgatum/ prairies

571. Hurd, P. D., and D. S. DeBell. 2001. Growth and early stand development of intensively cultured red alder plantings. New Forests 21:71-87.

Keywords: alders/ stand dynamics

572. Huston, M. A., and J. G. Isebrands. 1995. Monitoring interception of photosynthetically active radiation in forests. Bulletin of the Ecological Society of America 76(2):95-97.

Keywords: forests/ leaf area

573. Hutchinson, J. G. 1981. Fastgrowing young poplars make good panels, study says. Forest Industries 58-59.

Keywords: poplars/ by-products

574. Isebrands, J. G. 1981. Reaction wood anatomy and its effect on kraft paper from short rotation intensively cultured trees. International Association of Wood Anatomists (IAWA) Bulletin 2:57-58. Keywords: wood/ pulp, kraft/ short rotation intensive culture/ poplars

575. Isebrands, J. G. 1982. Toward a physiological basis of intensive culture of poplar. pp. 81-90. In Proceedings, 1982 TAPPI Research and Development Conference. TAPPI Press, Atlanta, Georgia. Keywords: silviculture/ crop management/ perennials/ poplars

576. Isebrands, J. G. 1984.

Biotechnology applications in forestry: An industrial perspective. pp. 3. In Proceedings, 1984 TAPPI Research and Development Conference. TAPPI Press, Atlanta, Georgia.

Keywords: biotechnology/ forestry
577. Isebrands, J. G. 1986. Production physiology at the whole-tree level. pp. 2. In Proceedings, 1986 Annual Meeting U.S.

Poplar Council. University of Washington, Seattle, Washington.

Keywords: poplars/ models, growth

578. Isebrands, J. G. 1996. Advances in intensive plantation culture of poplars in the North Central Region. In 1996 NCASI Central Lake States Regional Meeting Advance Summaries of Presentations. National Council of the Paper Industry for Air and Stream Improvement, Triangle Park, North Carolina.

Keywords: poplars/ plantations/ hybrids/ aspens

579. Isebrands, J. G., and T. E. Burk. 1992. Ecophysiological growth process models of short rotation forest crops. pp. 231-265. In Ecophysiology of Short

Rotation Forest Crops. C. P. Mitchell, J. B. Ford-Robertson, T. M. Hinckley, and L. Sennerby-Forsse (eds.). Elsevier Science Publishers Ltd., New York.

Keywords: ecophysiology/ models, growth/ short rotation woody crops

580. Isebrands, J. G., and R. J.

Ceulemans. 1995. Carbon acquisition and allocation in Populus. pp. 22. In International Poplar Symposium Program with Abstracts. University of Washington, Seattle, Washington.

Keywords: carbon/ Populus/ biomass crops

581. Isebrands, J. G., R. J. Ceulemans, and B. M. Wiard. 1988. Genetic variation in photosynthetic traits among Populus clones in relation to yield. Plant Physiology and Biochemistry 26:427-437.

Keywords: poplars/ cottonwoods/ carbon dioxide/ growth/ productivity

582. Isebrands, J. G., and R. E. Dickson. 1991. Measuring carbohydrate production and distribution: Radiotracer techniques and applications. pp. 357-392. In Techniques and Approaches in Forest Tree Ecophysiology. J. P. Lassoie and T. M. 
Hinckley (eds.). CRC Press, Inc., Boca

Raton, Florida.

Keywords: carbon/ carbohydrates

583. Isebrands, J. G., D. W. Einspahr, J. E. Phelps, and J. B. Crist. 1982. Kraft pulp and paper properties of juvenile hybrid larch grown under intensive culture. TAPPI 65:122-126.

Keywords: Larix eurolepsis/ whole-tree/ tear strength/ wood/ scanning electron microscopy/ bleaching/ pulp, kraft

584. Isebrands, J. G., A. R. Ek, and R. S. Meldahl. 1982. Comparison of growth model and harvest yields of short rotation intensively cultured Populus: A case study. Canadian Journal of Forest Research 12:58-63.

Keywords: Populus/ models, growth

585. Isebrands, J. G., A. Guenther, P. Harley, D. Helmig, L. Klinger, L. Vierling, P. Zimmerman, and C. Geron. 1999. Volatile organic compound emission rates from mixed deciduous and coniferous forests in northern Wisconsin, USA. Atmospheric Environment 33:2527-2536.

Keywords: emissions/ forests/ conifers/ Wisconsin

586. Isebrands, J. G., G. E. Host, L. Bollmark, J. R. Porter, S. Philippot, E. Stevens, and K. Rushton. 1996. A strategy for process modelling of shortrotation Salix coppice plantations. Biomass and Bioenergy 11(2/3):245-252.

Keywords: Coppice/ modeling/ Salix/ short rotation woody crops

587. Isebrands, J. G., and D. A. Michael. 1986. Effects of leaf morphology and orientation on solar radiation interception and photosynthesis in Populus. pp. 359381. In Proceedings, Crown and Canopy Structure in Relation to Productivity. T. Fujimori and D. Whitehead (eds.). Forestry and Forest Products Research Institute, Ibaraki, Japan.

Keywords: poplars/ leaf development/ radiation, solar/ leaf orientation/ photosynthesis/ Populus trichocarpal Populus deltoides/ hybrids/ clonal propagation/ leaves/ crown architecture/ biomass crops

588. Isebrands, J. G., and N. D. Nelson. 1980. Apportionment of 14C-labeled photosynthate within intensively cultured Populus trees. Plant Physiology (Suppl.) 65:211.

Keywords: Populus/ photosynthesis/ photosynthesis

589. Isebrands, J. G., and N. D. Nelson. 1983. Crown architecture of short-rotation, intensively cultured Populus: II. Branch morphology and distribution of leaves within the crown of Populus 'Tristis' as related to biomass production. Canadian Journal of Forest Research 12:853-864. Keywords: photosynthesis/ crown architecture/ short rotation woody crops/ poplars/ branch/ Populus tristis/ biomass crops/ Wisconsin/ leaves

590. Isebrands, J. G., and N. D. Nelson. 1983. Distribution of (14C)-labeled photosynthates within intensively cultured Populus clones during the establishment year. Physiologia Plantarum 59:9-18. Keywords: photosynthesis/ carbon/ poplars/ phenology/ Populus tristis/ Populus Euramericana/ shoots/ clonal propagation/ cottonwoods, hybrid

591. Isebrands, J. G., H. M. Rauscher, T. R. Crow, and D. I. Dickmann. 1989. Whole-tree growth process models based on structural-functional relationships. pp. 96112. In Process Modeling of Forest Growth Responses to Environmental Stress. R. K Dixon, R. S. Meldahl, G. A. Ruark, and W. G. Warren (eds.). Timber Press, Inc., Portland, Oregon.

Keywords: photosynthesis/ respiration/ carbon/ expert systems/ poplars/ physiology/ stress/ genetics/ breeding

592. Isebrands, J. G., J. A. Sturos, and J. B. Crist. 1979. Alternatives for the 
integrated utilization of short rotation intensively cultured Populus raw material. pp. 181-187. In Proceedings, 1979 TAPPI Annual Meeting. TAPPI Press, Atlanta, Georgia.

Keywords: short rotation intensive culture/ biomass crops/ Populus/ by-products

593. Isebrands, J. G., J. A. Sturos, and J. B. Crist. 1979. Integrated utilization of biomass: A case study of short rotation intensively cultured Populus raw material. TAPPI 62:67-70.

Keywords: short rotation woody crops/ poplars/ biomass crops/ pulp, kraft

594. Jakus, P. M., M. E. Downing, M. S. Bevelhimer, and J. M. Fly. 1997. Do sportfish consumption advisories affect reservoir angler's site choice? Agricultural \& Resource Economics Review 26(2):196204.

Keywords: ecosystems/ remediation/ contamination

595. James, R. R., B. A. Croft, and S. H. Strauss. 1998. Susceptibility of the cottonwood leaf beetle (Coleoptera: Chrysomelidae) to different strains and transgenic toxins of Bacillus thuringiensis. Environmental Entomology 28:108-115. Keywords: cottonwoods/ leaf beetle/ transgenic

596. James, R. R., S. P. Difazio, A. M. Brunner, and S. H. Strauss. 1998. Environmental effects of genetically engineered woody biomass crops. Biomass and Bioenergy 14(4):403-414.

Keywords: genetic modification/ herbicides/ insect resistance/ Bacillus thuringiensis/ Populus/ poplars, hybrid/ genes/ introgression/ lignin/ reproduction

597. James, R. R., and G. Newcombe. 2000. Defoliation patterns and genetics of insect resistance in cottonwoods. Canadian Journal of Forest Research 30:85-90. Keywords: defoliation/ genetics/ insect resistance/ cottonwoods/ Populus/ diseases/ leaf beetle
598. Johnsen, K. H., and D. K. Apsley. 1991. A simple method of measuring acetylene reduction of intact, nodulated black locust seedlings. Tree Physiology 9:501-506.

Keywords: acetylene reduction/ locusts, black

599. Johnsen, K. H., and B. C.

Bongarten. 1991. Allometry of acetylene reduction and nodule growth of Robinia pseudoacacia families subjected to varied root zone nitrate concentrations. Tree Physiology 9:507-522.

Keywords: acetyl groups/ nodulation/ Robinia pseudoacacia/ roots/ nitrates

600. Johnsen, K. H., and B. C. Bongarten. 1992. Relationships between nitrogen fixation and growth in Robinia pseudoacacia seedlings: A functional growth-analysis approach using $15 \mathrm{~N}$. Physiologia Plantarum 85:77-84.

Keywords: nitrogen fixation/ Robinia pseudoacacia/ seedlings/ fertilization

601. Johnson, D. W., and P. S. Curtis. 2001. Effects of forest management on soil carbon and nitrogen storage: Meta Analysis. Forest Ecol. Managmement 140:227-238.

Keywords: forest management/ carbon, soil/ nitrogen

602. Johnson, D. W., and V. H. Dale. 1986. Nitrogen cycling models and their application to forest harvesting. pp. 35. In Proceedings, IEA/BA Task II Workshop: Production Technology, Economics and Nutrient Cycling. R. Evers, E. H. White, B. Barkley, and L. Zsuffa (eds.). Report No. 2. International Energy Agency, Ottawa, Ontario, Canada.

Keywords: nitrogen/ forests/ nutrient management

603. Johnson, D. W., J. M. Kelly, W. T. Swank, D. W. Cole, H. Van Miegroet, J. W. Hornbeck, R. S. Pierce, and D. H. Van Lear. 1988. The effects of leaching and whole-tree harvesting on cation budgets of several forests. Journal of Environmental 
Quality 17:418-424.

Keywords: nutrient management/ forests/ whole-tree

604. Johnson, D. W., and D. E. Todd. 1987. Nutrient export by leaching and whole-tree harvesting in a loblolly pine and mixed oak forest. Plant and Soil 102:99109.

Keywords: nutrient management/ Pinus taeda/ forests/ whole-tree/ oaks

605. Johnson, D. W., and D. E. Todd. 1988. Nitrogen fertilization of young yellow-poplar and loblolly pine plantations at differing frequencies. Soil Science Society of America Journal 52:1468-1477. Keywords: Pinus taedal Liriodendron tulipifera/ growth responses/ fertilization

606. Johnson, D. W., D. C. West, D. E. Todd, and L. K. Mann. 1982. Effects of sawlog vs. whole-tree harvesting on the nitrogen, phosphorus, potassium, and calcium budgets of an upland mixed oak forest. Soil Science Society of America Journal 46(6):1304-1309.

Keywords: oaks/ residues/ nutrient cycling/ forest structure

607. E. A. Johnson (ed.). 1994. Industrial biomass production: Does it have much future. The Northern Logger and Timber Processor 22-25.

Keywords: biomass crops/ energy/ power generation

608. Johnson, G. R., and R. C. Kellison. 1984. Sycamore seedlings from the nursery: Not the same genetic composition as the collected seedlot. Tree Planters' Notes 35:34-35.

Keywords: sycamores/ seedlings/genetic variations

609. Johnson, K. H. , B. C. Bongarten, and L. R. Boring. 1991. Effects of nitrate on in vivo nitrate reductase activity of seedlings from three open-pollinated families of Robinia pseudoacacia. Tree Physiology 8:381-389.
Keywords: nitrates/ seedlings/ Robinia pseudoacacia/ locusts, black

610. Johnson, R. G. , D. A. Bangsund, and D. W. Meyer. 1990. Evaluation of Herbaceous Biomass Crops in the Northern Great Plains: Economic Analysis. ORNL/Sub/88-SB844C/2A. Oak Ridge National Laboratory, Oak Ridge, Tennessee. Keywords:

611. Johnston, C. A. 1988. Productivity of Wet Soils: Biomass of Cultivated and Natural Vegetation. ORNL/SUB/8418435/1. Oak Ridge National Laboratory, Oak Ridge, Tennessee.

Keywords: productivity/ soil properties/ vegetation, herbaceous/ biomass resources

612. Johnston, J. W. 1990. Evaluation of the Potential for Using Old-Field Vegetation as an Energy Feedstock: Biomass Yield, Chemical Composition, Environmental Concerns, and Economics. ORNL/TM11615. Oak Ridge National Laboratory, Oak Ridge, Tennessee.

Keywords: vegetation, old-field/ feedstocks/ biomass crops/ composition, chemical/ economics/ environmental effects

613. Jones, D. W. 1988. Monopsony and plant location in a Thunen land use model. Journal of Regional Science 28:317-327.

Keywords: model, Thunen/ economics/ plantations/ land

\section{Jones, D. W., and J. R. Krummel.} 1983. Location and the development of energy supplies from biomass sources. pp. 79-99. In Geographical Dimensions of Energy. F. J. Calzonetti and B. D. Solomon (eds.). Kluwer Academic Publishers for D. Reidel Publishing Company, Hingham, Massachusett.

Keywords: resource assessment/ biomass resources/ model, Thunen/ fuels

615. Jones, D. W., and J. R. Krummel. 1987. The location theory of the plantation. Journal of Regional Science 27:157-182. 
Keywords: models/ plantations/ location theory

616. Jones, R. M., M. A. Sanderson, S. P. Brown, and M. J. McFarland. 1998.

Dairy waste utilization for switchgrass production and nutrient fate. pp. 337. In Agronomy Abstracts.

Keywords: wastes/ switchgrass/ nutrient cycling

617. Jurgensen, M. F., D. J. Frederick, H. A. I. Madgwick, and G. R. Oliver. 1986. Soil development under Pinus radiata and Eucalyptus regnans plantations. New Zealand Journal of Forestry Science 16:69-77.

Keywords: soils/ forests/nutrients/ Pinus radiatal Eucalyptus regnans

618. Kang, H. D., and R. B. Hall. 1996. Light and scanning electron microscope observation of shoot formation in developing ovules of cottonwood (Populus deltoides). Korean Society of Plant Tissue Culture 23(2):83-88.

Keywords: tissue culture/ in-vitro culture/ germination/ poplars/ cottonwoods/ shoots

619. Kang, H. D., R. B. Hall, S. A. Heuchelin, H. S. McNabb, Jr., C. W. Mize, and E. R. Hart. 1997. Transgenic Populus: In vitro screening for resistance to cottonwood leaf beetle (Coleoptera: Chrysomelidae). Canadian Journal of Forest Research 27:943-944.

Keywords: Populus/ cottonwoods/ leaf beetle/ chrysomela

620. Kang, H. D., K-S. Park, and R. B. Hall. 1996. In vitro clonal propagation of Populus Euramericana (Populus deltoides $\times$ P. nigra). Research Bulletin of the Experiment Forests 4 :63-76.

Keywords: Populus Euramericanal clonal propagation/ tissue culture

621. Karnosky, D. F., Z. E. Cagnon, R. E. Dickson, M. D. Coleman, E. H. Lee, and J. G. Isebrands. 1996. Changes in growth, leaf abscission, and biomass associated with seasonal tropospheric ozone exposures of Populus tremuloides clones and seedlings. Canadian Journal of Forest Research 26:23-37.

Keywords: growth/ leaves/ biomass crops/ ozone/ Populus/ clones/ seedlings

622. Karnosky, D. F., G. K. Podila, D. Shin, and D. E. Riemenschneider. 1997. Micropropagation, Genetic Engineering, and Molecular Biology of Populus. RM-GTR-297. US Forest Service, Fort Collins, Colorado. Keywords: aroA gene/ transgenic/ ozone/ Populus

623. Kellison, R. C. 1978 . Genetic manipulation of southern hardwoods. pp. 111-120. In Proceedings, Eighth Forestry and Wildlife Symposium. Virginia Polytechnic Institute and State University, Blacksburg, Virginia.

Keywords: hardwoods/ genetic modification

624. Kellison, R. C. 1981. Progress in hardwood tree improvement. Forest Farmer 41:14-15.

Keywords: hardwoods/ genetic modification

625. Kellison, R. C. 1986 . Future technology and timber supply may change construction lumber products. Forest Farmer 45:24-26.

Keywords: lumber/ forestry/ timber

626. Kellison, R. C., R. Lea, and D. J. Frederick. 1983. Effect of silvicultural practices on wood quality of southern hardwoods. TAPPI 66:67-69.

627. Kellison, R. C., T. K. Slichter, and D. J. Frederick. 1979. Matching species to site for increased wood production. TAPPI 62:77-79.

Keywords: Pinus/ softwoods/ hardwoods/ seed/ genotypes/ forestry/ site characteristics

628. Kellison, R. C., and R. J. Weir. 1980. How forest genetics is helping grow 
better trees for tomorrow. TAPPI 63:57-61. Keywords: genetics/ pines/ seed/ Pinus

629. Kenney, W. A., R. L. Gambles, and L. Sennerby-Forsse. 1992. Feedstock characteristic and quality. pp. 267-284. In Ecophysiology of Short Rotation Forest Crops. C. P. Mitchell, J. B. Ford-

Robertson, T. M. Hinckley, and L. Sennerby-Forsse (eds.). Elsevier Science Publishers Ltd., New York.

Keywords: feedstocks/ short rotation woody crops/ short rotation intensive culture/ yields

630. Kenney, W. A., L. Sennerby-Forsse, and P. A. Layton. 1990. A review of biomass quality research relevant to the use of poplar and willow for energy conversion. Biomass 21:163-188.

Keywords: quality/ heritability/ wood/ heating values/ extractives/ cellulose/ hemicellulose/ lignin/ poplars/ willows

631. Kerr, S. N., and W. E. Sopper. 1982. Utilization of municipal sludge for woody biomass production in mined land. pp. 313317. In Symposium on Surface Mining Hydrology, Sedimentology, and Reclamation. University of Kentucky, Lexington, Kentucky.

Keywords: sludge/ short rotation woody crops/ mined land

632. Kiniry, J. R., M. A. Sanderson, J. R. Williams, C. R. Tischler, M. A. Hussey, W. R. Ocumpaugh, J. C. Read, G. V. Esbroeck, and Reed R.L. 1996.

Simulating Alamo Switchgrass with the ALMANAC Model. Agronomy Journal 88:602-606.

Keywords: switchgrass/ forage crops/ nutrients/ modeling

633. Kirmse, R. D., and J. T. Fisher. 1989. Species screening and biomass trials of woody plants in the semi-arid southwest United States. Biomass 18:15-29.

Keywords: short rotation intensive culture/ biomass crops/ coppice/ atriplex/ Leucaena/ Prosopis/ shrubs/ species selection
634. Kirmse, R. D., and B. E. Norton. 1985. Comparison of the reference unit method and dimensional analysis methods for two large shrubby species in the Caatinga woodlands. Journal of Range Management 38:425-428.

Keywords: Brazil/ Mimosa acutistipula/ jurema/ Pau Branco/ Auxemma oncocalyx

635. Klass, S., R. L. Bingham, L. FinkerTempleman, and P. Felker. 1985. Optimizing the environment for rooting cuttings of highly productive clones of Prosopis alba (mesquite/algarrobo). Journal of Horticultural Science 60:275284.

Keywords: Prosopis alba/ mesquite/ propagation

636. Klass, S., J. Wright, and P. Felker. 1987. Influence of auxins, thiamine and fungal drenches on the rooting of Prosopis alba clone B2V50 cuttings. Journal of Horticultural Science 62:97-100.

Keywords: Prosopis alba/ mesquite/ propagation/ pretreatments

637. Klopfenstein, N. B., K. K. Allen, F. J. Avila, S. A. Heuchelin, J. Martinez, R. C. Carman, R. B. Hall, E. R. Hart, and H. S. McNabb, Jr. 1997. Proteinase Inhibitor II gene in transgenic poplar: Chemical and biological assays. Biomass and Bioenergy 12(4):299-311.

Keywords: Populus/ agrobacterium/ proteinase inhibitors/ pests/genetic modification/ neomycin phosphotransferase/ Plagiodera versicolara/ poplars/ genes

638. N. B. Klopfenstein, Y. W. Chun, M-S. Kim, and M. R. Ahuja (eds.). 1997.

Micropropagation, Genetic Engineering, and Molecular Biology of Populus. RM-GTR297. US Forest Service, Fort Collins, Colorado.

Keywords: micropropagation/ genetics/ molecular biology/ Populus

639. Klopfenstein, N. B., H. S. McNabb, Jr., and R. B. Hall. 1993. Poplars in agroforestry systems: Using resistance to 
minimize disease risk. pp. 58. In The Third North American Agroforestry Conference Opportunities for Agroforestry in the Temperate Zone Worldwide. Iowa State University, Ames, Iowa.

Keywords: agroforestry/ poplars/ diseases

640. Klopfenstein, N. B., H. S. McNabb, Jr., E. R. Hart, R. B. Hall, R. D. Hanna, S. A. Heuchelin, K. K. Allen, N. Q. Shi, and R. W. Thornburg. 1993.

Transformation of Populus hybrids to study and improve pest resistance. Silvae Genetica 42:86-89.

Keywords: poplars, hybrid/ pests/ physiology

641. Kluender, R. A., T. W. Reisinger, W. B. Stuart, and K. D. Farrar. 1981. An Analysis of Several Alternatives to Oil as an Industrial Fuel. FWS 7-82. Virginia Polytechnic Institute and State University, Blacksburg, Virginia.

Keywords: fuels/ fuels

642. Koch, P., and T. E. Savage. 1980. Development of the Swathe-Felling mobile chipper. Journal of Forestry 78:17-21.

Keywords: harvesting/ Alnus rubral residues/ alders

643. Kopp, R. F., L. P. Abrahamson, C. A. Nowak, and E. H. White. 1992. Pre-emergent herbicides for site preparation in Salix plantings. The Forestry Chronicle 68:218-219.

Keywords: herbicides/ Salix/ New York/ phytotoxic effects/ weed control

644. Kopp, R. F., L. P. Abrahamson, E. H. White, K. F. Burns, and C. A. Nowak. 1997. Cutting cycle and spacing effects on biomass production by a willow clone in New York. Biomass and Bioenergy 12(5):313-319.

Keywords: Salix/ biomass crops/ shortrotation intensive culture/ short rotation intensive culture/ dedicated feedstock supply systems/ willows
645. Kopp, R. F., L. P. Abrahamson, E. H. White, C. A. Nowak, L. Zsuffa, and K. F. Burns. 1996. Woodgrass spacing and fertilization effects on wood biomass production by a Willow clone. Biomass and Bioenergy 11(6):451-457.

Keywords: Salix/ stand density/ fertilization/ irrigation/ biomass crops

646. Kopp, R. F., L. P. Abrahamson, E. H. White, T. A. Volk, C. A. Nowak, and R. C. Fillhart. 2001. Willow biomass production during ten successive annual harvests. Biomass \& Bioenergy 20:107. Keywords: willows/ Salix/ fertilization/ clones/ logistic growth curve/ growing season/ Populus

647. Kopp, R. F., L. P. Abrahamson, E. H. White, T. A. Volk, and J. M. Peterson. 1997. Willow Bioenergy Producer's Handbook. New York State Energy Research and Development Authority, Albany, New York.

Keywords: willows/ bioenergy

648. Kopp, R. F., W. A. Geyer, and W. R. Lovett. 1988. Silver maple seed sources for increased biomass production. Northern Journal of Applied Forestry 5:180184.

Keywords: survival rate/ growth/ stems/ maples, silver/ seed

649. Kopp, R. F., L. B. Smart, L. P. Abrahamson, C. A. Maynard, and J. G. Isebrands. 2000. Genetic improvement of Salix for the Northeast and North-Central United States. pp. 98. In 21st Session of the International Poplar Commission (IPC 2000) Poplar and Willow Culture: Meeting the Needs of Society and the Environment. J. G. Isebrands and J. Richardson (eds.). NC-215. North Central Research Station, St. Paul, Minnesota.

Keywords: genetics/ Salix

650. Kopp, R. F., L. B. Smart, C. A. Maynard, J. G. Isebrands, G. A. Tuskan, and L. P. Abrahamson. 2001. The development of improved willow clones for 
eastern North America. The Forestry Chronicle 77(2):287-292.

Keywords: willows/ Salix/ biomass crops/ breeding/ heterosis/ molecular genetics

651. Kopp, R. F., E. H. White, L. P. Abrahamson, C. A. Nowak, L. Zsuffa, and K. F. Burns. 1993. Willow biomass trials in Central New York State. Biomass and Bioenergy 5(2):179-187.

Keywords: Salix/ biomass crops/

fertilization/ clones/ willows

652. Koski, V., and D. I. Dickmann. 1992. Tree ideotype. Biomass and Bioenergy 2(1-6):71-75.

Keywords: morphology/ physiology/ production systems/ poplars/ Salix/ ideotype

653. Kroll, T., and M. E. Downing. 1995. Large-scale biomass plantings in Minnesota: Scale-up and demonstration projects in perspective. pp. 21-29. In Second Biomass Conference of the Americas. National Renewable Energy Laboratory, Golden, Colorado.

Keywords: biomass crops/Minnesota/ commercialization/ biomass/ poplars, hybrid

654. Krutovskii, K. V., S. Y. Erofeeva, J. E. Aagaard, and S. H. Strauss. 1999. Simulation of effects of dominace on estimates of population genetic diversity and differentiation. J. Hered. 90:499-502.

Keywords: genetic diversity

655. Kszos, L. A., M. E. Downing, L. L. Wright, J. H. Cushman, S. B.

McLaughlin, V. R. Tolbert, G. A. Tuskan, and M. E. Walsh. 2000. Bioenergy

Feedstock Development Program Status Report. ORNL/TM-2000/292. Oak Ridge National Laboratory, Oak Ridge, Tennessee. Keywords: woody crops/ energy crops, herbaceous/ economics/ resource assessment

656. Ku, L., S. M. Kaeppler, K. P. Vogel, K. Arumuganathan, and D. J. Lee. 1998. Nuclear DNA content and chromosome numbers in switchgrass. Great Plains Research 8:269-280.
Keywords: DNA/ chromosomes/ switchgrass/ Panicum virgatum

657. Ku, T. T., J. B. Baker, C. R. Blinn, and R. A. Williams. 1980. Understory biomass from southern pine forest. An energy source? Agronomy Abstracts p. 203. Keywords: pines/ biomass resources/ forests

658. Ku, T. T., J. B. Baker, C. R. Blinn, and R. A. Williams. 1981. Understory biomass for energy fuel. pp. 230-233. In Proceedings, First Biennial Southern Silvicultural Research Conference. J. P. Barnett (ed.). SO-34. U.S. Forest Service, Southeast Experiment Station, Asheville, North Carolina.

Keywords: biomass resources/ forests

659. Kull, O., A. Sober, M. D. Coleman, R. E. Dickson, J. G. Isebrands, Z. Gagnon, and D. F. Karnosky. 1996. Photosynthetic responses of aspen clones to simultaneous exposures of ozone and $\mathrm{CO}_{2}$.

Canadian Journal of Forest Research 26:639-648.

Keywords: photosynthesis/ aspens/ clones/ ozone/ carbon dioxide/ Populus

660. Kuo, M. L., D. D. Stokke, and H. S. McNabb, Jr. 1988. Microscopy of progressive decay of cottonwood by the brown-rot fungus Gloeophyllum trabeum. Wood and Fiber Science 20:405-414. Keywords: Populus deltoides/ hardwoods/ Gloeophyllum trabeum/ diseases/ cell walls/ scanning electron microscopy

661. Laarman, J. G., M. J. Vasievitch, and P. B. Durst. 1986. Techniques to harvest fast-growing energy plantations in Hawaii and the Philippines. pp. 256-267. In Proceedings, 18th IUFRO World Congress. International Union of Forestry Research Organizations, Ljubljana, Yugoslavia.

Keywords: harvesting/ energy crops

662. Labosky, Jr., P., T. W. Bowersox, and P. R. Blankenhorn. 1983. Kraft pulp yields and paper properties obtained from 
first and second rotations of three hybrid poplar clones. Wood and Fiber Science 15:81-89.

Keywords: poplars, hybrid/ pulpwood/ paper

663. Lai, Y. Z., R. L. Sajdak, G. D. Mroz, M. F. Jurgensen, and D. L. Schwandt. 1980. Wood and bark specific gravity determination as affected by water-soluble extractives loss. Wood Science 13:47-49. Keywords: specific gravity/ extractives/ composition, chemical

664. Land, Jr., S. B. 1982. Genetic Selection of American Sycamore for Biomass Production in the Mid-South. Final Report for the Period March 9, 1979-May 31, 1982. ORNL/Sub/81-9051/1. Oak Ridge National Laboratory, Oak Ridge, Tennessee.

Keywords: sycamores/ selection/genetic variations

665. Land, Jr., S. B., W. W. Elam, and M. Khan. 1995. Rejuvenated sycamore cuttings for energy plantations. Biomass and Bioenergy 8(4):225-264.

Keywords: clonal propagation/ Platanus occidentalis/ cytokinin/ growth responses/ roots/ biomass crops

666. Land, Jr., S. B., G. A. Tuskan, S. G. Dicke, and P. E. Patterson. 1983. Genetic, site, and within-tree variation in specific gravity and moisture content of young sycamore trees. TAPPI 66:149-153. Keywords: sycamores/ specific gravity/ moisture content/ genetic variations/ phenotype

667. Landsberg, J. J., and L. L. Wright. 1989. Comparisons among Populus clones and intensive culture conditions, using an energy-conversion model. Forest Ecology and Management 27:129-147.

Keywords: photosynthesis/ conversion/ poplars/ clonal propagation/ intensive culture/ conversion technologies/ models/ dry matter/ radiation, solar
668. Langseth, D., G. Larson, R. Stoffel, T. Kroll, and M. E. Downing. 1997. Seven steps in establishment to assure successful hybrid poplar plantings. pp. 215. In Third Biomass Conference of the Americas: Energy, Environment, Agriculture, and Industry. Elsevier. Keywords: poplars, hybrid/ economics

669. Lawrence, Jr., W. E., and W. Emory. 1981. In Field-Drying Logging Residues as an Industrial Fuel. Virginia Polytechnic Institute and State University, Industrial Forestry Operations Program, Blacksburg, Virginia.

Keywords: residues/ industry/ drying

670. Layton, P. A., and L. L. Wright. 1987. The role of genetic improvement in the Short Rotation Woody Crops Program. pp. 133-154. In Proceedings, Energy from Biomass and Wastes X. D. L. Klass (ed.). Institute of Gas Technology, Chicago, Illinois.

Keywords: genetics/ biomass crops/ wastes/ short rotation woody crops/ genetic modification

671. Layton, P. A., and L. L. Wright. 1988. Energy crop research advances the fundamentals of forest biology. pp. 27-40. In Proceedings, 9th Annual Southern Forest Biomass Workshop. Mississippi State University, Biloxi, Mississippi.

Keywords: forestry/ energy crops/ Populus/ genetic modification/ biotechnology/ physiology

672. Layton, P. A., L. L. Wright, T. W. Doyle, J. W. Ranney, J. H. Cushman, A. F. Turhollow, and J. W. Johnston. 1990. Accelerating energy crop growth via genetic techniques. pp. 397-424. In Proceedings, Energy from Biomass and Wastes XIII. D. L. Klass (ed.). Institute of Gas Technology, Chicago, Illinois. Keywords: growth/ breeding/ genetic modification/ biotechnology/ callus/ tissue culture/ somaclonal variations/ genetic modification 
673. Lea, R. 1987. Response of wetland forests to pumped agricultural waste-water. In The Hydrology and Pollutant Removal Effectiveness of Wetland Buffer Areas Receiving Pumped Agricultural Drainage Water. G. M. Chescheir, J. W. Gilliman, R. W. Skaggs, and R. G. Broadhead (eds.). Report 231. University of North Carolina, Water Resources Institute, Raleigh, North Carolina.

Keywords: forests/ wetlands/ wastewater/ environmental effects

674. Lea, R. 1987. Sweetgum Handbook: Short-Rotation Sweetgum Plantations, Establishment and Care in the Southeastern United States. ORNL/Sub/86-95909/1. Oak Ridge National Laboratory, Oak Ridge, Tennessee.

Keywords: sweetgum/ Liquidambar styraciflua/ crop management

675. Lea, R., and R. Ballard. 1982. Predicting loblolly pine growth response from $\mathrm{N}$ fertilizer using soil-N availability indices. Soil Science Society of America Journal 46:1096-1099.

Keywords: pines/ fertilization/ soil properties

676. Lea, R., and R. Ballard. 1982. Relative effectiveness of nutrient concentrations in living foliage and needle fall at predicting response of loblolly pine to $\mathrm{N}$ and $\mathrm{P}$ fertilization. Canadian Journal of Forest Research 12:713-717.

Keywords: pines/ fertilization/ nutrients

677. Ledin, S., L. Sennerby-Forsse, and L. L. Wright. 1998. Short rotation forestry production systems. pp. 87-103. In Accomplishments in Bioenergy Production Research 1995-1997. R. L. Gambles and G. Page (eds.). University of Toronto Press. Keywords: bioenergy/ wastewater/ harvesting/ biofuels/ coppice

678. Lemus, R. W., N. E. Molstad, E. C. Brummer, C. L. Burras, K. J. Moore, and R. Doorenbos. 1999. Switchgrass management for yield potential and biomass quality in the Chariton Valley, Iowa. pp. 110. In Agronomy Abstracts. Iowa State University, Ames, Iowa.

Keywords: switchgrass/ biomass crops/ Chariton Valley

679. Lemus, R. W., N. E. Molstad, C. L. Burras, and E. C. Brummer. 1998.

Switchgrass management and productivity in the Chariton River Valley, Iowa. pp. 276. In Agronomy Abstracts. Iowa State University, Ames, Iowa.

Keywords: switchgrass/ biomass crops/ Chariton Valley/ productivity

680. Lester, D. T., and D. S. DeBell. 1989. Geographic Variation in Red Alder. PNW-RP-409. U.S. Forest Service, Pacific Northwest Research Station, Portland, Oregon.

Keywords: genetics/ Alnus rubral provenance trials

681. Lewandowski, I., J. C. CliftonBrown, J. M. O. Scurlock, and W. Huisman. 2000. Miscanthus: European experience with a novel energy crop. Biomass \& Bioenergy 19:209-227.

Keywords: miscanthus/ biofuels/ energy crops/ productivity/ harvesting/ quality/ crop management/ drying/ storage/ combustion

682. Lin, D., M. Hubbes, L. Zsuffa, V. Tsarouhas, U. Gullberg, G. T. Howe, W. P. Hackett, G. Gardner, G. Furnier, and G. A. Tuskan. 1998. Stock

characterization and improvement: DNA fingerprinting and cold tolerance of Populus and Salix clones. pp. 119-129. In Accomplishments in Bioenergy Production Research 1995-1997 (Proceedings of the IEA Bioenergy Task XII End-of-Task Workshop). R. L. Gambles and G. Page (eds.). IEA Bioenergy.

Keywords: poplars, hybrid/ willows/ DNA/ bud set/ frost/ cold hardiness

683. Lin, S., B. F. Binder, and E. R. Hart. 1998. Chemical ecology of cottonwood leaf beetle adult feeding preferences on Populus. Journal of Chemical Ecology 24(11):1791- 
1802.

Keywords: Populus/ leaf beetle/

Chrysomela scripta/ insects/ leaf surface chemicals/ alcohols, long-chain fatty/ atocopherylquinone/ phenolic glycosides/ tremulacin/ salicortin

684. Lin, S., B. F. Binder, and E. R. Hart. 1998. Insect feeding stimulants from the leaf surface of Populus. Journal of Chemical Ecology 24(11):1781-1790. Keywords: Populus/ leaf beetle/ Chrysomela scripta/ insects/ leaf surface chemicals/ a-tocopherylquinone/ n-primary alcohols

685. Lindberg, J. E., V. R. Tolbert, A. Schiller, and J. M. Hanowski. 1998. Determining biomass crop management strategies to enhance habitat value for wildlife. pp. 1322-1332. In BioEnergy '98, Proceedings of the 8th Biennial Conference. Great Lakes Regional Biomass Energy Program, Chicago, Illinois.

Keywords: environment/ diversity/ birds/ wildlife/ biomass crops/ short-rotationwoody crops

686. Lindsey, C. A., and T. A. Volk. 1998. Economic and business model of a commercial willow energy crop enterprise. pp. 186-192. In Bioenergy '98. Great Lakes Regional Biomass Energy Program, Chicago, Illinois.

Keywords: economics/ willows/ energy crops

687. Liu, W., R. A. Merriam, V. D. Phillips, and D. Singh. 1993. Estimating short-rotation Eucalyptus saligna production in Hawaii: An integrated yield and economic model. Bioresource Technology 45:167176.

Keywords: short rotation woody crops/ Hawaii/ Eucalyptus saligna

688. Liu, W., V. D. Phillips, and D. Singh. 1992. A spatial model for the economic evaluation of biomass production systems. Biomass and Bioenergy 3:345-356.

Keywords: models/ economics/ biomass crops/ energy crops/ Eucalyptus salignal Hawaii

689. Liu, Z., and D. I. Dickmann. 1992. Abscisic acid accumulation in leaves of two contrasting hybrid poplar clones affected by nitrogen fertilization plus cyclic flooding and soil drying. Tree Physiology 11:109122.

Keywords: abscisic acid/ poplars, hybrid/ fertilization/ flooding/ soils/ poplars/ radioimmunoassays/ photosynthesis/ stomata/ cottonwoods, hybrid

690. Liu, Z., and D. I. Dickmann. 1992. Responses of two hybrid Populus clones to flooding, drought, and nitrogen availability. I. Morphology and growth. Canadian Journal of Botany 70:2265-2270.

Keywords: poplars, hybrid/ flooding/ drought/ fertilization/ morphology/ water relations/ gas exchange

691. Liu, Z., and D. I. Dickmann. 1993. Responses of two hybrid Populus clones to flooding, drought, and nitrogen availability. II. Gas exchange and water relations. Canadian Journal of Botany 71:927-928. Keywords: poplars, hybrid/ flooding/ drought/ nitrogen/ morphology

692. Long, C. E., W. A. Geyer, W. Loucks, and D. Hamm. 1982. Chemical Weed Control in Tree Plantings. Circular MF-656. Kansas State University, Extension Service, Manhattan, Kansas.

Keywords: herbicides/ crop management

693. Long, R., and T. W. Bowersox. 1984. Disease development and incubation period of Septoria canker on Populus hybrids. Penn State Research Briefs 16:2023.

Keywords: poplars/ Septoria

694. Long, R., T. W. Bowersox, and W. Merrill. 1986. Artificial inoculation of Populus hybrids with Septoria musiva. Canadian Journal of Forest Research 16:405-407. 
Keywords: poplars, hybrid/ Septoria musiva/ diseases

695. Lortz, D. A., D. R. Betters, and L. L. Wright. 1994. Production function for short-rotation woody-crop Populus spp. plantations. Canadian Journal of Forest Research 24:180-184.

Keywords: production/ short rotation woody crops/ poplars/ biomass crops

696. Lothner, D. C. 1990. Economic evaluations for short-rotation biomass production systems. Biomass 22:135-144. Keywords: biomass crops/ short rotation intensive culture/ economics

697. Lothner, D. C., E. A. Hansen, and D. A. Netzer. 1988. Growing and utilizing intensively cultured woody crops for energy: Some recent economic evidence from the north central United States. pp. 92-102. In Proceedings from the Workshop: Economic Evaluations of Biomass Oriented Systems for Fuel - International Energy Agency Bioenergy, Task III, Activity 4 (Applications of Systems Analysis). G. Lonner and A. Tornquist (eds.). Swedish University of Agricultural Sciences, Department of Forest-Industry-Market Studies, Garpenberg, Sweden. Keywords: yields/ short rotation woody crops/ short rotation intensive culture/ economics/ economics

698. Lothner, D. C., D. W. Rose, J. Zavitkovski, and K. D. Ferguson. 1981. A financial analysis of poplar intensive cultures in the Lake States. pp. 145-163. In Proceedings, Energy from Biomass and Wastes V. D. L. Klass (ed.). Institute of Gas Technology, Chicago, Illinois. Keywords: poplars/ intensive culture/ Lake States/ poplars, hybrid/ silviculture/ biomass crops/ economics

699. Lowenberg-DeBoer, J., and J. H. Cherney. 1989. Biophysical simulation for evaluating new crops: The case of switchgrass for biomass energy feedstock. Agricultural Systems 29:233-246.
Keywords: models/ economics/ fertilization/ harvesting/ switchgrass/ Panicum virgatum

700. Lowerts, G. A., and J. M. Stone. 1983. The effect of soil bulk density on nursery sweetgum seedling growth. Tree Planters' Notes 33:3-5.

Keywords: sweetgum/ soil properties/ nursery, forest

701. Lu, K., S. M. Kaeppler, K. P. Vogel, and K. Arumuganathan. 1998. Ploidy level and nuclear DNA content of switchgrass. pp. 36-37. In Abstracts of the XVI North American Prairie Conference. University of Nebraska-Kearney, Kearney, Nebraska.

Keywords: DNA/ switchgrass/ Panicum virgatum

702. Lynd, L. R., J. H. Cushman, R. J. Nichols, and C. E. Wyman. 1991. Fuel ethanol from cellulosic biomass. Science 251:1318-1323.

Keywords: fuel properties/ air quality/ climate/ energy

703. Lyons, S. 1987. Food, fuel \& hope. Idaho the University 4:11-14, 23-24. Keywords: rapeseed/ Brassica napus/ fuels

704. Ma, Z., C. W. Wood, and D. I. Bransby. 2000. Carbon dynamics subsequent to establishment of switchgrass. Biomass \& Bioenergy 18:93-104. Keywords: carbon/ switchgrass/ Panicum virgatum/ energy crops, herbaceous/ microbial biomass/ soil respiration/ row spacing/ harvest cycles

705. Ma, Z., C. W. Wood, and D. I. Bransby. 2000. Impacts of soil management on root characteristics of switchgrass. Biomass \& Bioenergy 18:105112.

Keywords: roots/ switchgrass/ Panicum virgatum/ roots

706. Ma, Z., C. W. Wood, and D. I. Bransby. 2000. Soil management impacts 
on soil carbon sequestration by switchgrass. Biomass and Bioenergy 18:469-477.

Keywords: carbon sequestration/ switchgrass/ Panicum virgatum/ energy crops/ cultural practices/ carbon, soil

707. Ma, Z., C. W. Wood, and D. I. Bransby. 2001. Impact of row spacing, nitrogen rate, and time on carbon partitioning of switchgrass. Biomass and Bioenergy 20:413-419.

Keywords: row spacing/ nitrogen/ carbon/ switchgrass/ Panicum virgatum/ Panicum virgatum/ agricultural management practices

708. Mahler, K. A., and D. L. Auld.

1986. National Winter Rapeseed Variety

Trial: 1985-86. Miscellanous Series

Bulletin No. 98. University of Idaho, College of Agriculture, Moscow, Idaho.

Keywords: rapeseed/ selection

709. Mahler, K. A., and D. L. Auld. 1988. Fatty Acid Composition of 2100 Accessions of Brassica. University of Idaho, Agricultural Experiment Station, Moscow, Idaho.

Keywords: fatty acid composition/ Brassica

710. Mahler, K. A., and D. L. Auld. 1988. National Winter Rapeseed Variety Trial: 1986-87. Miscellanous Series Bulletin No. 113. University of Idaho, College of Agriculture, Moscow, Idaho. Keywords: rapeseed/ selection

711. Mahler, K. A., and D. L. Auld. 1988. National Winter Rapeseed Variety Trial: 1987-88. Miscellanous Series Bulletin No. 120. University of Idaho, College of Agriculture, Moscow, Idaho. Keywords: rapeseed/ selection

712. Mahler, K. A., and D. L. Auld. 1989. National Winter Rapeseed Variety Trial: 1988-89. Miscellanous Series Bulletin No. 130. University of Idaho, College of Agriculture, Moscow, Idaho. Keywords: rapeseed/ selection
713. Mahler, K. A., and D. L. Auld. 1990. National Winter Rapeseed Variety Trial: 1989-90. Miscellanous Series Bulletin No. 140. University of Idaho, College of Agriculture, Moscow, Idaho. Keywords: rapeseed/ selection

714. Mahler, K. A., D. L. Auld, J. Bradley, D. G. Bullock, N. B. Christensen, L. O. Copeland, E. C. Gilmore, A. N. Hang, P. L. Mask, H. C. Minor, P. M. Porter, P. L. Raymer, D. E. Starner, and L. E. Welty. 1991. National Winter Rapeseed Variety Trial: 1990-91. Miscellaneous Series Bulletin No. 154. University of Idaho, Moscow, Idaho. Keywords: rapeseed/ selection

715. Majerus, K. A., and G. L. Rolfe. 1987. Changes in Soil Elemental Concentrations Under Short-Rotation Wood Production Systems. Forestry Research Report 87-1. University of Illinois, Agricultural Experiment Station, UrbanaChampaign, Illinois.

Keywords: soil properties/ nutrient management/ crop management

716. Majerus, K. A., and G. L. Rolfe. 1987. Seedling and Coppice Yields from Short-Rotation Wood Production Systems. Forestry Research Report 87-1. University of Illinois, Agricultural Experiment Station, Urbana-Champaign, Illinois.

Keywords: coppice/ seedlings

717. Malik, R. K., T. H. Green, G. F. Brown, and D. A. Mays. 2000. Use of cover crops in short rotation hardwood plantations to control erosion. Biomass \& Bioenergy 18:479-487.

Keywords: erosion/ short rotation woody crops/ sweetgum/ short rotation woody crops

718. Malik, R. K., T. H. Green, D. A. Mays, B. R. Bock, J. D. Joslin, F. C. Thornton, V. R. Tolbert, G. F. Brown, and K. Sistani. 1996. Cover crops for erosion control in bioenergy hardwood plantations. pp. 949-955. In Bioenergy '96, 
Partnerships to Develop and Apply Biomass Technologies.

Keywords: bioenergy/ cover crops/ erosion/ hardwoods

719. Mann, L. K., D. W. Johnson, D. C. West, D. W. Cole, J. W. Hornbeck, C. W. Martin, H. Riekerk, C. T. Smith, W. T. Swank, L. M. Tritton, and D. H. Van Lear. 1988. Effects of whole-tree and stem-only clear-cutting on postharvest hydrologic losses, nutrient capital, and regrowth. Forest Science 42:412-428. Keywords: harvesting/ moisture content/ nutrient cycling

720. Maposse, I. C. , D. I. Bransby, S. E. Sladden, and D. D. Kee. 1995. Biomass yields from eight switchgrass varieties over six years in Alabama. Agronomy Abstracts 138.

Keywords: biomass crops/ yields/ switchgrass/ Panicum virgatum/ Alabama

721. Marland, G., V. H. Dale, R. L. Graham, R. Luxmoore, S. Marland, S. B. McLaughlin, R. J. Norby, W. M. Post, T. J. Tschaplinski, G. A. Tuskan, and L. L. Wright. 1993. A Report from the Second U.S./Japan Workshop on Global Change Research: Environmental Response Technologies (Mitigation and Adaption). CONF-930285. U.S. Committee on Earth and Environmental Sciences, Honolulu, Hawaii.

Keywords: forest management/ carbon sequestration/ carbon dioxide

722. Marland, G., and S. Marland. 1992. Should we store carbon in trees? Water, Air, and Soil Pollution 64:181-195.

Keywords: carbon dioxide/ carbon/ climate/ growth, forest/ fuels, fossil/ biomass crops/ carbon

723. Marland, G., and A. F. Turhollow. 1990. $\mathrm{CO}_{2}$ Emissions from the Production and Combustion of Fuel Ethanol from Corn. ORNL/TM-11180. Oak Ridge National Laboratory, Oak Ridge, Tennessee.
Keywords: carbon dioxide/ ethanol/ corn/ fuels, biomass

724. Marland, G., and A. F. Turhollow. 1991. $\mathrm{CO}_{2}$ emissions from the production and combustion of fuel ethanol from corn. Energy 16:1307-1316.

Keywords: carbon dioxide/ ethanol/ corn/ fuels, biomass

725. Martin, S. A., L. S. Cooper, and A. R. Ehrenshaft. 1995. Biofuels Feedstock Development Program Bibliography 1978-1994. ORNL/M-4073. Oak Ridge National Laboratory, Oak Ridge, Tennessee.

Keywords: information resources

726. Martinez-Reyna, J. M., and K. P. Vogel. 1998. Controlled hybridization technique for switchgrass. Crop Science 38:876-878.

Keywords: hybridization/ switchgrass/ Panicum virgatum

727. Martinez-Reyna, J. M., and K. P. Vogel. 1998. Evaluation of three seed production methods in switchgrass. pp. 68 . In Abstracts of the 51st Annual Meeting of the Society for Range Management. Keywords: seed/ switchgrass/ Panicum virgatum

728. Martinez-Reyna, J. M., and K. P. Vogel. 2002. Incompatibility systems in switchgrass. Crop Science 42:1800-1805. Keywords: switchgrass/ incompatibility

729. Martinez-Reyna, J. M., K. P. Vogel, C. A. Caha, and D. J. Lee. 2001. Meiotic stability, chloroplast DNA polymorphisms, and morphological traits of upland $x$ lowland switchgrass reciprocal hybrids. Crop Science 41(5):1579-1583.

Keywords: chloroplast/ DNA/ switchgrass/ Panicum virgatum/ hybrids/ morphology

730. Mathusa, P. D. 1989. The New York State energy research and development authority's RD\&D program in biomass and municipal wastes. pp. 15-31. In 
Proceedings, Energy from Biomass and Wastes XII. D. L. Klass (ed.). Institute of Gas Technology, Chicago, Illinois.

Keywords: poplars, hybrid/ stand density/ planting density/ yields/ growth

731. Maxwell, D. L. , E. L. Kruger, and G. R. Stanosz. 1997. Effects of water stress on colonization of Poplar stems and excised leaf disks by Septoria musiva. The American Phytopathological Society 87(4):381-387.

Keywords: water stress/ colonization/ poplars/ Septoria musiva/ leaf disks/ drought

732. McCluskey, D. N., and R. F. Fisher. 1983. The effect of inoculum source on nodulation in Casuarina glauca. Commonwealth Forest Review 62:117-124. Keywords: Casuarina glauca/ nodulation

733. McCown, B. H. 1988. Recent advances in protoplast culture of horticultural crops: Ornamental trees and shrubs. Scientia Horticulturae 37:257-265. Keywords: biotechnology/ embryogenesis/ nodulation/ tissue culture/ regeneration

734. McCutchan, B. G. 1982. Effect of harvest season and spacing on coppice sweetgum biomass yields. pp. 113-124. In Proceedings, Fourth Central Hardwood Conference. University of Kentucky, Lexington, Kentucky.

Keywords: sweetgum/ coppice/ harvest cycles/ stand density

735. McDaniel, J. K., S. Dutta Guptam, and B. V. Conger. 1998. In vitro development and ontogeny of multiple shoots from mature caryopses of switchgrass. In Vitro Cell. Dev. Biol.-Pl. 34(3):70A.

Keywords: in vitro culture/ shoots/ switchgrass/ Panicum virgatum

736. McKell, C. M., J. R. Barker, and G. Van Epps. 1982. Environmental influences on big sagebrush (Artemisia tridentata) size. In Proceedings, Sagebrush Symposium. Utah State University, U.S.
Forest Service Shrub Research Laboratory, Provo, Utah.

Keywords: sagebrush/ growth responses

737. McLaughlin, R. A., E. A. Hansen, and P. E. Pope. 1987. Biomass and nitrogen dynamics in an irrigated hybrid poplar plantation. Forest Ecology and Management 18:169-188.

Keywords: poplars/ nitrogen/ irrigation

738. McLaughlin, R. A., P. E. Pope, and E. A. Hansen. 1985. Nitrogen fertilization and ground cover in a hybrid poplar plantation: Effects on nitrate leaching. Journal of Environmental Quality 14:241245.

Keywords: biomass crops/ weed control/ Lotus corniculatus/ poplars/ environmental effects/ nitrates

739. McLaughlin, R. A., P. E. Pope, and E. A. Hansen. 1985. Nitrogen management in a biomass plantation. pp. 77-84. In Proceedings, Forest Soils: A Resource for Intensive Forest Management. 1984 Lake States Forest Soils Conference. G. D. Mroz and C. C. Trettin (eds.). Miscellanous Publication 85-1. Michigan Technological University, School of Forestry and Wood Products, Houghton, Michigan.

Keywords: poplars/ fertilization

740. McLaughlin, S. B. 1993. New switchgrass biofuels research program for the Southeast. pp. 111-115. In Proceedings of the Annual Automotive Technology Development Contractors' Coordination Meeting. SAE International, Warrendale, Pennsylvania.

Keywords: switchgrass/ Panicum virgatum/ biofuels/ perennials/ Panicum virgatum/ feedstocks

741. McLaughlin, S. B., J. H. Bouton, D. I. Bransby, B. V. Conger, W. R. Ocumpaugh, D. J. Parrish, C. M. Taliaferro, K. P. Vogel, and S. D. Wullschleger. 1997. Evaluating and improving switchgrass as a bioenergy crop. 
pp. 137-143. In Third Biomass Conference of the Americas: Energy, Environment, Agriculture, and Industry. Elsevier. Keywords: switchgrass/ Panicum virgatum/ bioenergy/ physiology/ breeding/ biotechnology

742. McLaughlin, S. B., J. H. Bouton, D. I. Bransby, B. V. Conger, W. R. Ocumpaugh, D. J. Parrish, C. M. Taliaferro, K. P. Vogel, and S. D. Wullschleger. 1998. Developing switchgrass as a bioenergy crop. pp. 282299. In Proceedings of the Fourth National New Crops Symposium. J. Janick (ed.). ASHS Press, Alexandria, Virginia. Keywords: switchgrass/ Panicum virgatum/ biomass crops

743. McLaughlin, S. B., D. I. Bransby, and D. J. Parrish. 1994. Perennial grass production for biofuels: Soil conservation considerations. In Bioenergy '94: Using Biofuels for a Better Environment (Proceedings of the Sixth National Bionergy Conference). J. Farrell, S. Sargent, D. Swanson, and R. Nelson (eds.). Western Regional Biomass Energy Program. Keywords: perennials/ biofuels/ soil conservation

744. McLaughlin, S. B., D. G. De La Torre Ugarte, C. T. Garten, Jr., L. R. Lynd, M. A. Sanderson, V. R. Tolbert, and D. D. Wolf. 2002. High-Value Renewable Energy from Prairie Grasses. Environ. Sci. Technol. 36:2122-2129. Keywords: renewable energy/ grasses/ bioenergy/ economics

745. McLaughlin, S. B., R. Samson, D. I. Bransby, and A. E. Wiselogel. 1996. Evaluating physical, chemical, and energetic properties of perennial grasses as biofuels. pp. 1-8. In Bioenergy '96, Partnerships to Develop and Apply Biomass Technologies. Keywords: switchgrass/ Panicum virgatum/ energy/ fuel properties/ feedstocks/ perennials/ grasses
746. McLaughlin, S. B., and M. E. Walsh. 1998. Evaluating environmental consequences of producing herbaceous crops for bioenergy. Biomass and Bioenergy 14(4):317-324.

Keywords: switchgrass/ Panicum virgatum/ bioenergy/ energy balance/ carbon/ energy crops, herbaceous

747. McLaughlin, S. B., and M. E. Walsh. 2000. Developing and evaluating switchgrass as a bioenergy crop. pp. 209211. In Proc., Second Eastern Native Grass Symposium.

Keywords: switchgrass/ Panicum virgatum/ bioenergy

748. McLetchie, D. N., and G. A. Tuskan. 1995. Gender determination in Populus.

Norwegian Journal of Agricultural Sciences 18:57-66.

Keywords: gender/ Populus/ molecular genetics/ genetic correlations

749. McMahon, B. G., R. D. Hanna, and R. B. Hall. 1993. Selection and breeding of Populus clones in the north central region. pp. 2-12. In Proceedings of the Second Northern Forest Genetics Association Conference. University of Minnesota, St. Paul, Minnesota.

Keywords: cottonwoods/ breeding/ poplars/ clonal propagation

750. McMillin, J. D., M. J. Anderson, E. E. Butin, and E. R. Hart. 1998. Phenology and infestation patterns of the cottonwood twig borer (Lepidoptera: Tortricidae) in Iowa. The Great Lakes Entomologist 31(3\&4):181-190.

Keywords: phenology/ infestation/ cottonwoods/ insects/ diseases/ Populus/ crop management

751. McNabb, Jr., H. S. 1997.

Micropropagation, Genetic Engineering, and Molecular Biology of Populus. RM-GTR297. US Forest Service, Fort Collins, Colorado.

Keywords: prairies/ Populus/ diseases/ forests 
752. McNabb, Jr., H. S., R. B. Hall, and M. E. Ostry. 1982. Biological and physical modifications of the environment and the resulting effect upon the host-parasite interactions in short-rotation tree crops. pp. 60-71. In Proceedings, Third International Workshop on the Genetics of Host-Parasite Interactions in Forestry: Resistance to Diseases and Pests in Forest Trees. H. M. Heybroek, B. R. Stephan, and K. Von Weissenberg (eds.). Centre for Agricultural Publishing and Documentation, Wangeningen, The Netherlands.

Keywords: parasites/ short rotation woody crops/ environmental effects

753. McNabb, Jr., H. S., E. R. Hart, and R. B. Hall. 1991. Disease and insect resistance: A key to successful short rotation woody crops systems. Ames Forester 78:31-33.

Keywords: poplars, hybrid/ breeding/ genetic modification/ pests/ diseases

754. McNabb, Jr., H. S., N. B. Klopfenstein, R. D. Hanna, R. B. Hall, E. R. Hart, S. A. Heuchelin, and R. W. Thornburg. 1991. A field trial of transgenic hybrid poplar trees:

Establishment and growth through the second season. pp. 155-159. In Biological Monitoring of Genetically Engineered Plants and Microbes. D. R. MacKenzie and S. C. Henry (eds.). Agricultural Research Institute, Bethesda, Maryland. Keywords: poplars, hybrid/genes/ growth

755. McNabb, Jr., H. S., M. E. Ostry, R. S. Sonnelitter, and P. E.

Gerstenberger. 1982. The effect and possible integrated management of Septoria musiva in intensive, short-rotation culture of Populus in the north central states. pp. 5158. In Proceedings, 1982 North American Poplar Council Meeting. E. Zavitkovski and E. A. Hansen (eds.). Kansas State University, Manhattan, Kansas. Keywords: Populus/ Septoria musival intensive culture/ pests
756. McNabb, Jr., H. S., M. E. Ostry, P. A. Tipton, R. S. Sonnelitter, J. M. Site, and E. S. Caldbeck. 1981. Fungicidal management of Septoria canker of Populus grown under short-rotation, intensive culture. Phytopathology 71:242.

Keywords: pests/ Septoria/ Populus/ intensive culture

757. McNabb, Jr., H. S., R. S. Sonnelitter, and M. E. Ostry. 1981. Leaf and stem disease severity and coppice ability of four Populus hybrids. Iowa Academy of Science Proceedings 2:88.

Keywords: coppice/ Populus/ diseases

758. McRoberts, R. E. 1988 . Forest Growth Modelling and Prediction. NC-120. U.S. Forest Service, North Central Forest Experiment Station, Duluth, Minnesota. Keywords: models/ regression analysis

759. Megalos, M. A., D. J. Frederick, A. Clark III, and D. R. Phillips. 1986. Biomass and energy content of southern Piedmont hardwood forests. pp. 72. In Proceedings, Fourth Southern Biomass Energy Research Conference. University of Georgia, Athens, Georgia.

Keywords: hardwoods/ energy content/ feedstocks

760. Megalos, M. A., D. J. Frederick, A. Clark III, and D. R. Phillips. 1986. Biomass, Nutrient and Energy Content of Southern Piedmont Hardwood Forests. Hardwood Research Cooperative Series No. 5. North Carolina State University, School of Forest Resources, Raleigh, North Carolina.

Keywords: harvesting/ yields/ productivity/ hardwoods/ energy content/ feedstocks

761. Meilan, R. 1997. Floral induction in woody angiosperms. New Forests 14:179202.

Keywords: floral homeotic genes/ girdling/ grafting/ growth retardants/ phytohormones/ flowering 
762. Meilan, R., K. H. Han, C. Ma, R. R. James, J. A. Eaton, B. J. Stanton, E. Hoien, R. P. Crockett, and S. H. Strauss. 2000. Development of glyphosate-tolerant hybrid cottonwoods. TAPPI 83(1):164-166.

Keywords: glyphosate/ cottonwoods, hybrid/ herbicides/ Populus

763. Meilan, R., C. Ma, S. Cheng, J. A. Eaton, L. K. Miller, R. P. Crockett, S. P. DiFazio, and S. H. Strauss. 1999. High levels of Roundup and leaf-beetle resistance in genetically engineered hybrid cottonwoods. pp. 29-38. In Hybrid Poplars in the Pacific Northwest: Culture, Commerce and Capability. K. A. Blatner and J. J. Johnson (eds.). Washington State University, Pullman, Washington. Keywords: Roundup/ leaf-beetle/ cottonwoods, hybrid/ genetic modification/ glyphosate/ insect resistance/ field trials/ pests

764. Meilan, R., and S. H. Strauss. 1997. Micropropagation, Genetic Engineering, and Molecular Biology of Populus. RM-GTR297. US Forest Service, Fort Collins, Colorado.

Keywords: genetics/ poplars, hybrid/ clones/ Populus

765. Meinzer, F. C. , R. J. Ceulemans, and T. M. Hinckley. 1994. Water flux in a hybrid poplar stand. Tree Physiology 14:1005-1018.

Keywords: water relations/ poplars, hybrid

766. Meskimen, G. F. 1984. Testing

Eucalyptus Clones in Florida and Establishment Report for 1982 Plantings (Supplement to Study Plan). FS-SE-111321. U.S. Forest Service, Southeastern Forest Experiment Station, Asheville, North Carolina.

Keywords: breeding/ Eucalyptus grandis/ clonal propagation

767. Meskimen, G. F., D. L. Rockwood, and K. V. Reddy. 1987. Development of Eucalyptus clones for a summer rainfall environment with periodic severe frosts. New Forest 3:197-205.

Keywords: Eucalyptus grandis/ Eucalyptus saligna/ cold hardiness/ clonal selection/ clonal propagation

768. Messina, M. G., R. Ballard, and D. J. Frederick. 1983. A test of a single disk for estimation of hardwood bole and branch nutrient concentrations. Forest Science 19:618-626.

Keywords: nutrients/ experimental design/ hardwoods

769. Messina, M. G. , D. J. Frederick, and A. Clark III. 1986. Nutrient content and distribution in natural southern coastal plain hardwoods. Biomass 10:59-79. Keywords: biomass crops/ nutrients/ site characteristics/ hardwoods

770. Meyer, D. W., D. E. Lippert, W. E. Norby, and D. O. Erickson. 1991.

Evaluation of herbaceous biomass crops in North Dakota. Agronomy Abstracts p. 153. Keywords: energy crops, herbaceous/ biomass resources/ North Dakota

771. Meyer, D. W., W. E. Norby, D. O. Erickson, and R. G. Johnson. 1994. Evaluation of Herbaceous Biomass Crops in the Northern Great Plains (Final Report). ORNL/Sub/88-SB844/2. Oak Ridge National Laboratory, Oak Ridge, Tennessee. Keywords: energy crops, herbaceous/ biomass resources/ Great Plains

772. Michael, D. A., D. I. Dickmann, K. W. Gottschalk, N. D. Nelson, and J. G. Isebrands. 1985. Determining photosynthesis of tree leaves in the field using a portable ${ }^{14} \mathrm{CO}_{2}$ apparatus: Procedures and problems. Photosynthetica 19:98-108.

Keywords: poplars/ photosynthesis/ carbon dioxide

773. Michael, D. A., D. I. Dickmann, and N. D. Nelson. 1979. Photosynthesis, $\mathrm{CO}_{2}$ compensation, and stomatal conductance of young poplar plants grown under intensive 
culture. Plant Physiology (Suppl.) 63:121. Keywords: poplars/ photosynthesis/ carbon dioxide/ stomata

774. Michael, D. A., J. G. Isebrands, D. I. Dickmann, and N. D. Nelson. 1990.

Photosynthesis patterns during the establishment year within two Populus clones. Tree Physiology 6:11-27. Keywords: poplars/ poplars, hybrid/ light/ clonal variations

775. Michler, C. H. 1993. In vitro genetic selection for woody plant improvement. pp. 443-455. In Micropopagation of Woody Plants, Chapter 26. M. R. Ahuja (ed.). Kluwer Academic Publishers, The Netherlands.

Keywords: clonal propagation/genetic modification/ woody crops/ somaclonal variations/ somatic cells/ tissue culture

776. Michler, C. H., and E. O. Bauer. 1987. Selection for herbicide tolerance in Populus to sulfometuron methyl in vitro. In Proceedings, Symposium on Genetic Manipulation of Woody Plants. Michigan State University, East Lansing, Michigan. Keywords: Populus/ herbicides

777. Michler, C. H., and E. O. Bauer. 1987. Selection of somaclonal variants for herbicide tolerance in tissue cultured plantlets of Populus. In Vitro 23:47A. Keywords: herbicides/ poplars/ herbicides/ somaclonal variations

778. Michler, C. H., and E. O. Bauer. 1987. Somatic embryogenesis in plant cell cultures of Populus. In Vitro 23:46A.

Keywords: poplars/ tissue culture/ embryogenesis

779. Michler, C. H., and E. O. Bauer. 1990. Biochemical mechanism of herbicide tolerance of in vitro selected Populus. In Vitro 26:47A.

Keywords: herbicides/ enzymes, target/ Populus
780. Michler, C. H., and E. O. Bauer. 1991. EPSP synthase activity of in vitro selected glyphosate tolerant Populus spp. In Vitro 27:129.

Keywords: poplars, hybrid/ herbicides/ Populus

781. Michler, C. H., and B. E. Haissig. 1988. Increased herbicide tolerance of in vitro selected hybrid poplar. pp. 183-189. In Somatic Cell Genetics of Woody Plants. M. R. Ahuja (ed.). Kluwer Academic Publishers, The Netherlands.

Keywords: poplars, hybrid/ growth/ herbicides/ somaclonal variations

782. Michler, C. H., T. M. Voelker, and

E. O. Bauer. 1989. Production of putative herbicide tolerant plants from somatic embryos regenerated from in vitro selected callus. In Vitro 25:62A.

Keywords: herbicides/ poplars, hybrid/ somaclonal variations

783. Michler, C. H., T. M. Voelker, and R. J. Moioffer. 1992. Field evaluation of herbicide-tolerant hybrid poplar somaclones. In Vitro Cellular and Developmental Biology (Program Issue: 1992 World Congress on Cell and Tissue Culture) 28:105A.

Keywords: herbicides/ poplars, hybrid/ somaclonal variations

784. Milauskas, S. J., R. G. Oderwald, and W. B. Stuart. 1981. Extensively managed short-rotation Appalachian hardwood coppice for energy. pp. 81-85. In WOODPOWER: New Perspectives on Forest Usage. J. J. Talbot and W. Swanson (eds.). Pergamon Press, New York. Keywords: hardwoods/ coppice/ energy crops

785. Miller, R. O., J. B. Levenson, and G. T. Howe. 1984. The Costs of Genetic Test Plantations. MICHCOTIP Notes Vol. 1, No. 1. Michigan State University, East Lansing, Michigan.

Keywords: genetics/ plantations 
786. Miyasaka, S. C. 1984. Comparison of quick- and slow-release fertilizers in young plantings of Eucalyptus species. Tree Planters' Notes 35:20-24.

Keywords: Eucalyptus/ fertilization

787. Miyasaka, S. C., E. N. Okazaki, and D. P. Bartholomew. 1983. The effect of lime and micronutrients on Eucalyptus saligna $\mathrm{Sm}$. seedling growth. Bioenergy $\mathrm{p}$. 11.

Keywords: fertilization/ horticulture/ peat/ boron/ sulfur/ Eucalyptus saligna

788. Miyasaka, S. C., A. W. Yeh, and C. D. Whitesell. 1983. Use of soil and tissue testing in forest crops. pp. 139-141. In Proceedings, First Fertilizer and Ornamentals Workshop. Research Extension Series 037. University of Hawaii at Manoa, College of Tropical Agriculture and Human Resources, Manoa, Hawaii. Keywords: nutrient management/ fertilization/ forests

789. Miyata, E. S., H. M. Steinhilb, R. L. Sajdak, and M. S. Coffman. 1982. Roller Chopping for Site Preparation in Wisconsin: A Case Study. NC-223. U.S. Forest Service, North Central Forest Experiment Station, Duluth, Minnesota.

Keywords: site preparation

790. Mohamed, R., R. Meilan, and S. H. Strauss. 2001. Complex behavior of a copper-inducible gene expression system in transgenic poplar. Forest Genetics 8(1):6972.

Keywords: Populus/ copper/ transgenic

791. Molstad, N. E., R. W. Lemus, C. L. Burras, E. C. Brummer, and K. J. Moore. 1999. Landscapes, soil morphology, and switchgrass yield in the Chariton River Valley, Iowa. pp. 266. In Agronomy Abstracts. Iowa State University, Ames, Iowa.

Keywords: landscapes/ soil properties/ switchgrass/ Chariton Valley/ Iowa/ productivity
792. Moltzan, B. D. , R. W. Stack, and

P. A. Mason. 1993. First report of

Melampsora occidentalis on Populus trichocarpa in Central United States. Plant

Disease Reporter 77:953.

Keywords: Melampsora occidentalis/

Populus trichocarpa/ poplars/ cottonwoods/ rusts

793. Moore, L. M., M. E. Ostry, L. F. Wilson, M. J. Morin, and H. S. McNabb, Jr. 1982. Impact of Septoria canker caused by $S$. Musiva on nursery stock and first-year plantation coppice. pp. 44-50. In Proceedings, 1982 North American Poplar Council Meeting. J. Zavitkovski and E. A. Hansen (eds.). Kansas State University, Manhattan, Kansas.

Keywords: Septoria musiva/ coppice/ nursery, forest/ pathogens

794. Moore, L. M., L. F. Wilson, and M. E. Ostry. 1982. Poplar-and-willow borer injury in two hybrid poplar clones. pp. 59-62. In Proceedings, 1982 North American Poplar Council Meeting. J. Zavitkovski and E. A. Hansen (eds.). Kansas State University, Manhattan, Kansas.

Keywords: pests/ poplars

795. Moser, L. E., and K. P. Vogel. 1995. Switchgrass, big bluestem, and indiangrass. pp. 409-420. In Forages: An Introduction to Grassland Agriculture. Iowa State University, Ames, Iowa.

Keywords: switchgrass/ Panicum virgatum/ big bluestem/ indiangrass/ flowering/ grasslands

796. Moser, L. E., J. A. Young, and K. P. Vogel. 1997. Germination of switchgrass as affected by diurnal temperature regimes. pp. 118-119. In Agronomy Abstracts. Keywords: germination/ switchgrass/ Panicum virgatum

797. Mosjidis, J. A. 1993. Variability for Biomass Production and Plant Composition in Sericea lespedeza Germplasm. Final Report on a Field and Laboratory Research 
Program for the Period September 30, 1990 to December 31, 1991. ORNL/90-SG301/1. Oak Ridge National Laboratory, Oak Ridge, Tennessee.

Keywords: biomass crops/ composition/ Sericea lespedeza

798. Mosjidis, J. A. 1996. Variability for biomass production and plant composition in Sericea lespedeza. Biomass \& Bioenergy 11(1):63-68.

Keywords: fiber/ biomass crops/ composition/ Sericea lespedeza/ energy crops, herbaceous/ nitrogen/ lignin/ cellulose/ hemicellulose/ holocellulose

799. Mroz, G. D., D. J. Frederick, M. F. Jurgensen, R. L. Sajdak, A. Clark III, D. R. Phillips, and K. Slattery. 1979. Biomass and nutrient removal on three northern hardwood sites in upper Michigan. pp. 408. In Proceedings, Symposium on Impact of Intensive Harvesting on Forest Nutrient Recycling. State University of New York, Syracuse, New York.

Keywords: hardwoods/ nutrient cycling/ productivity

800. Mroz, G. D., M. F. Gale, M. F. Jurgensen, D. J. Frederick, and A. Clark III. 1984. Composition, structure, and standing crop biomass of two climax northern hardwood stands in upper Michigan. Canadian Journal of Forest Research 15:78-82.

Keywords: hardwoods/ composition

801. Mroz, G. D., M. F. Jurgensen, and

D. J. Frederick. 1985. Soil nutrient changes following whole tree harvesting on three northern hardwood sites. Soil Science Society of America Journal 49:1552-1557. Keywords: whole-tree/ soil properties/ hardwoods/ nutrient cycling

802. Mroz, G. D., M. F. Jurgensen, Y. Z. Lai, H. O. Liechty, D. C. Hamlin, M. F. Gale, R. L. Sajdak, and H. M. Stinhilb. 1984. Application of Sugar Maple and Black Locust to the Biomass/Energy Plantation Concept: Final Report April
1984. ORNL/Sub/81-9058/3. Oak Ridge National Laboratory, Oak Ridge, Tennessee. Keywords: maples, sugar/ locusts, black/ Robinia pseudoacacia/ Acer saccharinum/ biomass crops/ biomass crops/ nitrogen fixation

803. Muir, J. P., M. A. Sanderson, W. R. Ocumpaugh, R. M. Jones, and R. L.

Reed. 2001. Biomass production of 'Alamo' switchgrass in response to nitrogen, phosphorus, and row spacing in diverse environments. Agronomy Journal 93:896901.

Keywords: nitrogen/ phosphorus/ row spacing

804. Murphey, W. K., T. W. Bowersox, and P. R. Blankenhorn. 1979. Selected wood properties of young Populus hybrids. Wood Science 11:257-262.

Keywords: composition/ poplars, hybrid/ intensive culture

805. Myers, G. C., and J. B. Crist. 1986. Feasibility of manufacturing hardboard from short-rotation intensively cultured Populus. Forest Products Journal 36:37-44.

Keywords: Populus tristis/ short rotation intensive culture/ lumber

806. Nance, W. L., G. A. Tuskan, C. D. Nelson, and R. L. Doudrick. 1992.

Potential applications of molecular markers for genetic analysis of host-pathogen systems in forest trees. pp. 1036-1043. In Canadian Journal of Forestry Research. Keywords: short rotation woody crops

807. Naughton, G. G., and W. A. Geyer. 1982. An economic analysis of energy forest plantations. pp. 94-98. In Proceedings, Energy from Biomass, 2nd European Communities Conference. A. Strub, P. Chartier, and G. Schlesser (eds.). Applied Science Publishers, Berlin. Keywords: economics/ energy crops/ crop management

808. Naughton, G. G., and N. E. Jennings. 1979. Firewood Plantations. 
Circular C-605. Kansas State University, Cooperative Extension Service, Manhattan, Kansas.

Keywords: plantations/ fuelwood

809. Nei, M. 1978. Genetic distance between populations. Am. Nat. 106:283292.

Keywords: genetics/ populations

810. Nelson, N. D. 1984. Woody plants are not inherently low in photosynthetic capacity. Photosynthetica 18:600-605. Keywords: woody crops/ photosynthesis

811. Nelson, N. D. 1985. North Central Forest Experiment Station biotechnology program: Application to tree improvement. pp. 14-22. In Proceedings, Eighteenth Southern Forest Tree Improvement Conference. R. C. Schmidtling and M. M. Griggs (eds.). U.S. Forest Service, Southern Forest Experiment Station, Gulfport, Mississippi.

Keywords: biotechnology/genetic modification/ somaclonal variations/ tissue culture/ DNA/ herbicides/ diseases/ poplars

812. Nelson, N. D. 1985. Photosynthetic life span of attached poplar leaves under favorable controlled environmental conditions. Forest Science 31:700-705. Keywords: photosynthesis/ life span/ poplars/ carbon dioxide/ senescence/ leaf development/ stomata/ mesophyll resistance/ cytokinin/ benzyladenine/ chlorophyll

813. Nelson, N. D., T. E. Burk, and J. G. Isebrands. 1981. Crown architecture of short-rotation, intensively cultured Populus: I. Effects of clone and spacing on first-order branch characteristics. Canadian Journal of Forest Research 11:73-81.

Keywords: branch/ crown architecture/ poplars/ clonal propagation/ short rotation intensive culture/ stand density

814. Nelson, N. D., and P. Ehlers. 1981. Comparative photosynthesis within two poplar clones grown in growth room, greenhouse, and field. Plant Physiology
(Suppl.) 65:93.

Keywords: photosynthesis/ poplars/ greenhouse

815. Nelson, N. D., B. E. Haissig, and D. E. Riemenschneider. 1984. Applying the new somaclonal technology to forestry. In Proceedings, 1984 TAPPI Research and Development Conference. TAPPI Press, Atlanta, Georgia.

Keywords: somaclonal variations/ tissue culture/ poplars/ pines

816. Nelson, N. D., and J. G. Isebrands. 1983. Late-season photosynthesis and photosynthate distribution in an intensivelycultures Populus nigra $\times$ laurifolia clone. Photosynthetica 17:537-549.

Keywords: photosynthesis/ intensive culture/ poplars/ clonal propagation/ poplars, hybrid

817. Nelson, N. D., J. G. Isebrands, and W. E. Hillis. 1978. Some effects of ethylene on the morphology and anatomy of Eucalyptus and Populus seedlings. International Association of Wood Anatomy Bulletin 2-3:48.

Keywords: Eucalyptus gomphocephalal seedlings/ Populus deltoides/ ethylene

818. Nelson, N. D., J. A. Sturos, P. R. Fritschel, and L. D. Satter. 1984.

Ruminant feedstuff from the commercial foliage of hybrid poplars grown under intensive culture. Forest Products Journal 34:37-44.

Keywords: poplars, hybrid/ short rotation intensive culture/ foliage/ vacuum airlift segregation/ poplars

819. Nemethy, E. K. 1984. Biochemicals as an energy resource. Plant Science 2:117129.

Keywords: biochemicals/ biomass crops/ biomass crops

820. Netzer, D. A. 1984 . Herbicide Trials on European Larch in Northern Wisconsin. NC-318. U.S. Forest Service, North Central Forest Experiment Station, St. Paul, 
Minnesota.

Keywords: herbicides/ larches/ competition/ weeds/ intensive culture/ seedlings/ Larix decidua

821. Netzer, D. A. 1984. Hybrid Poplar Plantations Outgrow Deer Browsing Effects. NC-325. U.S. Forest Service, North Central Forest Experiment Station, St. Paul, Minnesota.

Keywords: intensive culture/ establishment/ deer/ poplars, hybrid

822. Netzer, D. A. 1995 . Use of Sulfometuron in Hybrid Poplar Energy Plantations. Research Paper NC-366. U.S. Department of Agriculture, Forest Service, St. Paul, Minnesota.

Keywords: poplars, hybrid/ plantations/ herbicides

823. Netzer, D. A., and E. A. Hansen. 1983. Controlling weeds in poplars by dormant season glyphosate overspray. pp. 141-142. In Proceedings, North Central Weed Control Conference. Iowa State University Press, Ames, Iowa. Keywords: herbicides/ survival rate

824. Netzer, D. A., and E. A. Hansen. 1986. Integrated pest management in intensive forestry. pp. 98-108. In Proceedings, Integrated Pest Management Symposium for Northern Forests. University of Wisconsin Cooperative Extension, Madison, Wisconsin. Keywords: poplars/ weed control/ pests/ nutrient management/ rusts/ pests

825. Netzer, D. A., and E. A. Hansen. 1992. Seasonal Variation in Hybrid Poplar Tolerance to Glyphosate. NC-311. U.S. Forest Service, North Central Forest Experiment Station, St. Paul, Minnesota. Keywords: intensive culture/ weed control/ herbicides/ growing season/ clonal variations/ short rotation woody crops/ poplars, hybrid

826. Netzer, D. A., and E. A. Hansen. 1994. Establishing and tending poplar plantations in the North-Central U.S. pp. 79-87. In Proceedings of the International Energy Agency, Task IX, Activity 1 Symposium "Mechanization in Short Rotation, Intensive Culture Forestry.” B. J. Stokes and T. P. McDonald (eds.). U.S Dept. of Agriculture, Forest Service, Southern Forest Exp. Station, Auburn, Alabama.

Keywords: plantations/ poplars, hybrid/ short rotation intensive culture/ establishment/ crop management

827. Netzer, D. A., and E. A. Hansen. 1994. Establishment and tending of poplar plantations in North-Central U.S. pp. 79-87. In Mechanization in Short Rotation, Intensive Culture Forestry.

Keywords: poplars/ plantations/ establishment/ short rotation intensive culture/ crop management

828. Netzer, D. A., and N. V. Noste. 1978. Herbicide Trials in Intensively Cultured Populus Plantations in Northern Wisconsin. NC-235. U.S. Forest Service, North Central Forest Experiment Station, St. Paul, Minnesota.

Keywords: competition/ clonal propagation/ weeds/ herbicides/ intensive culture/ poplars/ plantations/ Wisconsin

829. Netzer, D. A., D. E.

Riemenschneider, and E. O. Bauer. 1996. Pre and post flush application of Dupont R6447 in hybrid poplar plantations. pp. 105-109. In Proceedings of the North Central Weed Science Society Conference. North Central Weed Science Society, Champaign, Illinois.

Keywords: poplars/ herbicides

830. Netzer, D. A., D. E. Riemenschneider, D. L. Lanseth, R. B. Pierce, and M. E. Downing. 2002. Use of plastic mulch as an alternative to herbicides in large-scale Populus plantations in the mid-west United States. pp. 112-114. In Fourth International Conference on Forest Vegetation Management: Technical, Environmental and Economic Challenges. 
Institut National de la Recherche Agronomique, Champenoux, France. Keywords: Populus/ mulch/ crop management/ silviculture

831. Newcombe, G. 1996 . The specificity of fungal pathogens of Populus. pp. 223246. In Biology of Populus and its Implications for Management and Conservation. R. F. Stettler, Jr., H. D. Bradshaw, P. E. Heilman, and T. M. Hinckley (eds.). NRC Research Press, Ottawa, Canada.

Keywords: ecology/ conservation/ Populus/ pathogens

832. Newcombe, G. 1997. First report of Marssonina brunnea f. sp. brunnea on hybrid poplar in the Pacific Northwest. Plant Disease (February):231.

Keywords: Marssonina brunnea/ poplars, hybrid

833. Newcombe, G. 1998. Association of Mmdl, major gene for resistance to Melampsora medusae f. sp. deltoidae, with quantitative traits in poplar rust. Phytopathology 88:114-121.

Keywords: genetics/ Melampsora medusael rusts

834. Newcombe, G. 1998. Southerly extension of poplar leaf blight (Linospora tetraspora) in the Pacific Northwest. Plant Disease 82:590.

Keywords: poplars/ leaf blight

835. Newcombe, G. 2000. First report of Pestalotiopsis populi-nigrae on poplar in North America. Plant Disease (May):595. Keywords: Pestalotiopsis populi-nigrael poplars, hybrid/ Populus/ diseases

836. Newcombe, G. 2000. Inheritance of resistance to Glomerella cingulata in Populus. Canadian Journal of Forest Research 30(4):639-644.

Keywords: Populus/ diseases/ Glomerella cingulata
837. Newcombe, G., and H. D. Bradshaw, Jr. 1996. Quantitative trait loci conferring resistance in hybrid poplar to leaf spot caused by Septoria populicola. Canadian Journal of Forest Research 26:1943-1950. Keywords: loci/ poplars, hybrid/ diseases/ Septoria populicola

838. Newcombe, G., and H. D. Bradshaw, Jr. 1996. Quantitative trait loci conferring resistance in hybrid poplar to Septoria populicola, the cause of leaf spot. Canadian Journal of Forest Research 26(11):19431950.

Keywords: loci/ poplars, hybrid/ diseases/ Septoria populicola

839. Newcombe, G., H. D. Bradshaw, Jr., G. A. Chastagner, and R. F. Stettler. 1996. A major gene for resistance to Melampsora medusae f.sp. deltoidae in a hybrid poplar pedigree. Phytopathology 86:87-94.

Keywords: genetics/ diseases/ Melampsora medusael poplars, hybrid

840. Newcombe, G., and G. A. Chastagner. 1993. First report of the Eurasian poplar leaf rust fungus, Melampsora larici-populina, in North America. Plant Disease 77:532-535. Keywords: poplars/ rusts/ Melampsora larici-populinal diseases

841. Newcombe, G., and G. A. Chastagner. 1993. A leaf rust epidemic of hybrid poplar along the Lower Columbia river caused by Melampsora medusae. Plant Disease 77:528-531.

Keywords: rusts/ poplars, hybrid/ Melampsora medusae

842. Newcombe, G., G. A. Chastagner, B. Callan, and M. E. Ostry. 1995. An epidemic of Septoria leaf spot on Populus trichocarpa in the Pacific Northwest in 1993. Plant Disease 79:212.

Keywords: Septoria/ Populus trichocarpal diseases 
843. Newcombe, G., G. A. Chastagner, and S. K. McDonald. 1994. Additional coniferous aecial hosts of the poplar leaf rusts, Melampsora larici-populina and $M$. medusae f. sp. deltoidae. Plant Disease 78:1218.

Keywords: aecial hosts, coniferous/ poplars/ rusts/ diseases

844. Newcombe, G., G. A. Chastagner, W. Schuette, and B. J. Stanton. 1994. Mortality among hybrid poplar clones in a stool bed following leaf rust caused by Melampsora medusae f. sp. deltoidae. Canadian Journal of Forest Research 24:1984-1987.

Keywords: poplars, hybrid/ rusts/ diseases

845. Newcombe, G., B. Stirling, and H. D. Bradshaw, Jr. 2001. Abundant pathogenic variation in the new hybrid rust Melampsora $\times$ columbiana on hybrid popalr. Phytopathology 91(10):981-985.

Keywords: host-parasite specificity/ Melampsora/ poplars/ diseases/ rusts

846. Newcombe, G., B. Stirling, S. K. McDonald, and H. D. Bradshaw, Jr. 2000. Malampsora $\times$ columbiana, a natural hybrid of M. medusae and M. occidentalis. Mycol. Res. 104:261-274.

Keywords: Melampsora medusael Melampsora occidentalis/ hybrids

847. Newcombe, G., B. Stirling, S. K. McDonald, and H. D. Bradshaw, Jr. 2000. Melampsora x columbiana, a natural hybrid of $M$. medusae and $M$. occidentalis. Mycol. Res. 104(3):261-274.

Keywords: Melampsora/ rusts/ Populus/ diseases

848. Newcombe, G., and C. Van Oosten. 1997. Variation in resistance to Venturia populina, the cause of poplar leaf and shoot blight in the Pacific Northwest. Canadian Journal of Forest Research 27:883-889. Keywords: Venturia populinal poplars/ diseases/ leaf blight
849. Nguyen, P. V., D. I. Dickmann, K. S. Pregitzer, and R. L. Hendrick. 1990.

Late-season changes in allocation of starch and sugar to shoots, coarse roots, and fine roots in two hybrid poplar clones. Tree Physiology 7:95-105.

Keywords: harvesting/ composition, chemical/ irrigation/ fertilization/ carbohydrates

850. Niese, J. N., and T. F. Strong. 1992. Economic and tree diversity trade-offs in managed northern hardwoods. Canadian Journal of Forest Research 22:1807-1813. Keywords: economics/ biodiversity/ hardwoods

851. Noh, E. W., S. C. Minocha, and D. E. Riemenschneider. 1988. Adventitious shoot formation from embryonic explants of red pine (Pinus resinosa). Physiologia Plantarum 74:119. 124.

Keywords: cytokinin/ benzyladenine/ tissue culture/ embryogenesis/ somaclonal variations/ pines/ Pinus resinosa

852. Ocumpaugh, W. R., S. Archer, and J. W. Stuth. 1996. Switchgrass recruitment from broadcast seed vs seed fed to cattle. Journal of Range Management 49(4):368-371.

Keywords: switchgrass/ Panicum virgatum/ seed/ cattle

853. Oderwald, R. G., W. B. Stuart, and K. D. Farrar. 1980. The forest model file: A mapped stand library at Virginia Tech. Forest Science 26:193-194.

Keywords: models/ forests

854. Oderwald, R. G., W. B. Stuart, and E. C. Ford III. 1979. Location of full tree centers of gravity for Appalachian hardwoods. Southern Journal of Applied Forestry 3:123-124.

Keywords: hardwoods/ center of gravity

855. Odjakova, M. K., and B. V. Conger. 1998. The influence of osmotic pretreatment on the embryogenic capacity of 
switchgrass (Panicum virgatum L.) suspension cultures. In Vitro Cell. Dev. Biol.-Pl. 34(3):72A.

Keywords: switchgrass/ Panicum virgatum

856. Odjakova, M. K., and B. V. Conger. 1999. The influence of osmotic pretreatment and inoculum age on the initiation and regenerability of switchgrass suspension cultures. In Vitro Cell Dev. Biol.--Plant 35:442-444.

Keywords: Panicum virgatum/ somatic embryogenesis/ mannitol/ maltose

857. Oregon State University. 1997. Tree Genetic Engineering Research Cooperative Annual Report 1996-97. Oregon State University, Corvallis, Oregon. Keywords: cottonwoods, hybrid/ insects/ pests/ genetic modification

858. Oregon State University. 1998. Tree Genetic Engineering Research Cooperative Annual Report 1997-1998. Oregon State University, Corvallis, Oregon.

Keywords: cottonwoods, hybrid/ insects/ pests/ genetic modification

859. Oregon State University. 1999. Tree Genetic Engineering Research Cooperative Annual Report 1998-1999. Oregon State University, Corvallis, Oregon.

Keywords: cottonwoods, hybrid/ insects/ pests/ genetic modification

860. Ostry, M. E. 1981. Important diseases of intensively grown poplars in the North Central region. Phytopathology 71:247.

Keywords: diseases/ poplars

861. Ostry, M. E. 1987. Biology of Septoria musiva and Marssonina brunnea in hybrid Populus plantations and control of Septoria canker in nurseries. European Journal of Forest Pathology 17(3):158-165. Keywords: Septoria musival Marssonina brunnea/ poplars, hybrid/ Septoria

862. Ostry, M. E. 1994. Poplar disease research: Host resistance and pathogen variability. Norwegian Journal of Agricultural Sciences 18: 89-94.

Keywords: poplars/ diseases/ diseases/ pathogens

863. Ostry, M. E. Somatic variation in disease resistance of poplars. pp. 74-78. In Proceedings, International Energy Agency Joint Meeting of the Task V Activity Groups on Exchange of Genetic Material, Pest/Disease Management, and Joint Trials of Alnus, Populus, and Salix.

Keywords: somatic variations/ diseases/ poplars

864. Ostry, M. E. 1997.

Micropropagation, Genetic Engineering, and Molecular Biology of Populus. RM-GTR297. US Forest Service, Fort Collins, Colorado.

Keywords: in vitro screening/ diseases/ poplars/ pathogens/ molecular biology

865. Ostry, M. E. 1999. Exotic forest pests - pathology and entomology. Journal of Forestry 97(8):A3.

Keywords: pests/ entomology

866. Ostry, M. E., and N. A. Anderson. 2001. Melampsora leaf rust of willow causing a stem canker in Minnesota. Plant Disease 85:229.

Keywords: Melampsora/ rusts/ willows/ stem cankers

867. Ostry, M. E., and W. E. Berguson. 1994. Selecting hybrid poplars to reduce disease risk may also reduce biomass yield. Tree Planters' Notes Keywords: poplars, hybrid/ diseases/ biomass crops

868. Ostry, M. E., B. Bucciarelli, S. Sain, W. P. Hackett, and N. A. Anderson. 1990. Developing tissue culture systems for increasing the disease resistance of aspen. pp. 315-318. In Proceedings, Aspen Symposium '89. R. D. Adams (ed.). NC140. U.S. Forest Service, North Central Forest Experiment Station, St. Paul, Minnesota. 
Keywords: clonal propagation/ aspens/ poplars, hybrid/ tissue culture/ diseases/ cankers

869. Ostry, M. E., P. E. Gerstenberger, and H. S. McNabb, Jr. 1983. Control of Septoria canker in hybrid Populus nurseries. Phytopathology 73(5):837.

Keywords: Septoria/ poplars, hybrid

870. Ostry, M. E., W. P. Hackett, C. H. Michler, R. Serres, and B. H. McCown. 1994. Influence of regeneration method and tissue source on the frequency of somatic variation in Populus to infection by Septoria musiva. Plant Science 97(2):209-215.

Keywords: embryogenesis/ tissue culture/ micro-cross sections/ roots/ diseases/ poplars, hybrid/ clonal variations/ somaclonal variations

871. Ostry, M. E., and H. S. McNabb, Jr. 1982. Preventing blackstem damage to Populus hardwood cuttings. pp. 36-43. In Proceedings, 1982 North American Poplar Council Meeting. J. Zavitkovski and E. A. Hansen (eds.). Kansas State University, Manhattan, Kansas.

Keywords: Populus/ diseases

872. Ostry, M. E., and H. S. McNabb, Jr. 1985. Susceptibility of Populus species and hybrids to disease in the North Central United States. Plant Disease Reporter 69:755-757.

Keywords: diseases/ intensive culture/ poplars/ hybrids

873. Ostry, M. E., and H. S. McNabb, Jr. 1986. Populus Species and Hybrid Clones Resistant to Melampsora, Marssonina, and Septoria. NC-272. U.S. Forest Service, North Central, St. Paul, Minnesota. Keywords: Septoria musival Melampsora medusael Marssonina brunnea/ intensive culture

874. Ostry, M. E., and H. S. McNabb, Jr. 1990. Minimizing disease injury to hybrid poplars. Journal of Environmental
Horticulture 8:96-98.

Keywords: poplars/ diseases/ Septoria

875. Ostry, M. E., R. E. McRoberts, K. T. Ward, and R. Resendez. 1988. Screening hybrid poplar in vitro for resistance to leaf spot caused by Septoria musiva. Plant Disease 72:497-499.

Keywords: poplars/ diseases/ Septoria musiva

876. Ostry, M. E., and C. H. Michler. 1993. Use of biotechnology for tree improvement in Populus model systems. pp. 471-483. In Micropropagation of Woody Plants, Chapter 28. M. R. Ahuja (ed.). Kluwer Academic Publishers, The Netherlands.

Keywords: biotechnology/ tree improvement/ poplars

877. Ostry, M. E., and D. D. Skilling. 1988. Somatic variation in resistance of Populus to Septoria musiva. Plant Disease 72(8):724-727.

Keywords: diseases/ tree improvement

878. Ostry, M. E., D. D. Skilling, T. L. Ettinger, W. P. Hackett, and P. E. Read. 1986. Selection for resistance to Septoriamusiva in Populus utilizing somaclonal variation. Phytopathology 76(10):1119. Keywords: Septoria musiva/ Populus/ somaclonal variations

879. Ostry, M. E., D. D. Skilling, O. Y. Lee-Stadelmann, and W. P. Hackett. 1990. Recovery of somatic variation in resistance of Populus to Septoria musiva. pp. 113-116. In Plant Aging: Basic and Applied Approaches. R. Rodriguez (ed.). Plenum Press, New York.

Keywords: somaclonal variations/ tissue culture/ callus/ somatic variations/ diseases

880. Ostry, M. E., and K. T. Ward. 1991. Bibliography of Populus cell and tissue culture. Gen. Tech. Rep. NC-146. U.S. Department of Agriculture, Forest Service, St. Paul, Minnesota. 
Keywords: Populus/ tissue culture/ aspens/ poplars/ molecular genetics

881. Ostry, M. E., L. F. Wilson, and H. S. McNabb, Jr. 1989. Impact and Control of Septoria musiva on Hybrid Poplars. NC133. U.S. Forest Service, North Central Forest Experiment Station, St. Paul, Minnesota.

Keywords: diseases/ poplars/ intensive culture/ Septoria musiva

882. Ostry, M. E., L. F. Wilson, H. S. McNabb, Jr., and L. M. Moore. 1989. A Guide to Insect, Disease, and Animal Pests of Poplars. Agricultural Handbook 677. U.S. Forest Service, North Central Forest Experiment Station, Madison, Wisconsin. Keywords: poplars/ diseases/ viruses/ parasites/ cankers/ defoliation/ insects

883. Otegbeye, G. O., and R. C. Kellison. 1980. Genetics of wood and bark characteristics of Eucalyptus viminalis. Silvae Genetica 40:27-31.

Keywords: Eucalyptus viminal/ genetics

884. Pallardy, S. G., and T. T. Kozlowski. 1979. Early root and shoot growth of Populus clones. Silvae Genetica 28:153156.

Keywords: Populus/ growth

885. Pallardy, S. G., and T. T. Kozlowski. 1979. Frequency and length of stomata of 21 Populus clones. Canadian Journal of Botany 57:2519-2523.

Keywords: Populus/ stomata

886. Pallardy, S. G., and T. T. Kozlowski. 1979. Relationships of leaf diffusion resistance of Populus clones to leaf water potential and environment. Ecologia 40:371-380.

Keywords: Populus/ water potential

887. Pallardy, S. G., and T. T. Kozlowski. 1979. Stomatal response of Populus clones to light intensity and vapor pressure deficit. Plant Physiology (Suppl.) 64:112-114.
Keywords: stomata/ poplars/ clonal propagation/ light/ vapor pressure deficit

888. Pallardy, S. G., and T. T. Kozlowski. 1980. Cuticle development in the stomatal region of Populus clones. New Phytologist 85:363-368.

Keywords: Populus/ stomata

889. Pallardy, S. G., and T. T. Kozlowski. 1981. Water relations of Populus clones. Ecology 62:159-169.

Keywords: drought/ water relations/ poplars/ clonal propagation/ soil properties/ stomata/ water relations/ water stress

890. Palmer, M. A., M. E. Ostry, and A. L. Schipper, Jr. 1980. How to Identify and Control Marssonina Leaf Spot and Canker of Poplars. U.S. Forest Service, North Central Forest Experiment Station, St. Paul, Minnesota.

Keywords: poplars/ diseases

891. Palmer, M. A., and A. L. Schipper, Jr. 1979. Resistance of poplars to Septoria canker resistance. Phytopathology 69:1041. Keywords: poplars/ Septoria/ diseases

892. Parrish, D. J., W. L. Daniels, D. D. Wolf, M. H. Genthner, S. Nagle, and P. Sullivan. 1988. Screening herbaceous species on marginal Piedmont sites. pp. 3639. In Proceedings, Southern Biomass Conference. Auburn University, Auburn, Alabama.

Keywords: energy crops/ soils/ sorghum/ harvesting/ land

893. Parrish, D. J. , W. L. Daniels, D. D. Wolf, M. H. Genthner, and R. Wheeler. 1985. Screening herbaceous species for the Piedmont. Agronomy Abstracts p. 127. Keywords: energy crops/ soils/ sorghum/ harvesting/ land

894. Parrish, D. J. , D. D. Wolf, J. A. Balasko, J. T. Greene, M. Rasnake, and J. H. Reynolds. 1999. Maximizing switchgrass biomass production. pp. 114. 
In Agronomy Abstracts. American Society of Agronomy, Minneapolis, Minnesota. Keywords: switchgrass/ Panicum virgatum/ biomass crops/ Panicum virgatum/ crop management

895. Parrish, D. J., D. D. Wolf, and W. L. Daniels. 1993. Perennial Species for Optimum Production of Herbaceous Biomass in the Piedmont (Management Study, 1987-1991) Final Report. ORNL/Sub/85-27413/7. Oak Ridge National Laboratory, Oak Ridge, Tennessee. Keywords: species selection/ land/ soils/ economics/ erosion/ crop management/ physiology

896. Parrish, D. J. , D. D. Wolf, W. L. Daniels, J. S. Cundiff, and D. H. Vaughan. 1991. A five-year study of herbaceous energy crops. pp. 447-464. In Proceedings, Energy from Biomass and Wastes XIV. D. L. Klass (ed.). Institute of Gas Technology, Chicago, Illinois. Keywords: grasses/ legumes/ soils/ switchgrass/ Panicum virgatum/ lovegrass/ erosion/ perennials

897. Parrish, D. J., D. D. Wolf, W. L. Daniels, D. H. Vaughan, and J. S. Cundiff. 1990. Perennial Species for Optimum Production of Herbaceous Biomass in the Piedmont. ORNL/Sub/8527413/5. Oak Ridge National Laboratory, Oak Ridge, Tennessee.

Keywords: species selection/ land/ soils/ economics/ erosion/ crop management/ physiology

898. Parrish, D. J. , D. D. Wolf, and C. Garten. 2000. Root Mass, C, N, and Organic Matter Dynamics under Switchgrass and Tall Fescue. pp. 139. In Agronomy Abstracts. American Society of Agronomy, Minneapolis, Minnesota. Keywords: switchgrass/ Panicum virgatum/ Panicum virgatum/ carbon/ nitrogen/ roots

899. Parrish, D. J. , D. D. Wolf, P. R. Peterson, and W. L. Daniels. 1999.
Managing switchgrass as a biofuels feedstock (abstract). pp. 26. In The Second Eastern Native Grass Symposium.

Keywords: switchgrass/ Panicum virgatum/ biofuels/ feedstocks

900. Parrish, D. J. , D. D. Wolf, P. R. Peterson, and W. L. Daniels. 1999.

Successful establishment of switchgrass (abstract). pp. 25. In The Second Eastern Native Grass Symposium.

Keywords: switchgrass/ Panicum virgatum

901. Parrish, D. J., D. D. Wolf, J. H. Reynolds, J. T. Greene, J. A. Balasko, and M. Rasnake. 1995. Switchgrass as a biofuels feedstock for the upper southeast. In Proceedings of the Second Biomass Conference of America.

Keywords: switchgrass/ Panicum virgatum/ biofuels/ feedstocks

902. Parrish, D. J. , D. D. Wolf, J. H. Reynolds, J. T. Greene, J. A. Balasko, and M. Rasnake. 1995. Variety and management studies with switchgrass as a biofuels crop. Agronomy Abstracts 174. Keywords: switchgrass/ Panicum virgatum/ biofuels

903. Peeler, K. C., and D. S. DeBell. 1986. Variation in Damage from GrowingSeason Frosts Among Open-Pollinated Families of Red Alder. PNW-RN-464. U.S. Forest Service, Pacific Northwest Research Station, Olympia, Washington.

Keywords: alders/ growing season/ cold hardiness/ superphosphate/ seedlings/ Alnus rubra

904. Peelle, E. 2000. Biomass Stakeholder Views and Concerns: Environmental Groups and Some Trade Associations. ORNL/TM1999/271. Oak Ridge National Laboratory, Oak Ridge, Tennessee.

Keywords: biomass crops/ environment

905. Peelle, E. 2000. Stakeholder Views and Concerns about Bioenergy: Organizational Focus, Driver Issues and Uncertaintly. In Proceedings of the Ninth 
Biennial Bioenergy Conference - Bioenergy 2000: Moving Technology into the Marketplace.

Keywords: stakeholders/ bioenergy/

biomass crops/ residues/ wastes/

environmentalists/ farmers/ energy crops/

driver issues

906. Perlack, R. D., S. Das, and J. W. Ranney. 1986. The economic evaluation of SRIC energy plantations. pp. 58-61. In Proceedings, Seventh Southern Forest Biomass Workshop. D. L. Rockwood (ed.). University of Florida, Gainesville, Florida. Keywords: economics/ short rotation intensive culture/ plantations/ coppice/ risk

907. Perlack, R. D., and W. A. Geyer. 1987. Wood energy plantation economics in the Great Plains. Journal of Energy

Engineering 113:92-101.

Keywords: biomass energy/ plantations/ economics/ Great Plains/ short rotation intensive culture/ feedstocks/ Kansas/ maples, silver/ harvesting/ planting density

908. Perlack, R. D., and J. W. Ranney. 1987. Cost objective overview for short rotation woody crops. pp. 230-237. In Proceedings - IEA/BA/Task II Workshop: Economics Evaluations of Short Rotation Biomass Energy Systems. U.S. Forest Service, North Central Forest Experiment Station, Duluth, Minnesota.

Keywords: economics/ short rotation woody crops/ short rotation intensive culture/ feedstocks/ genetics/ crop management/ harvesting

909. Perlack, R. D., and J. W. Ranney. 1987. Economics of short-rotation intensive culture for production of wood energy feedstocks. Energy 12:1217-1226. Keywords: short rotation intensive culture/ economics/ regional analysis

910. Perlack, R. D., and J. W. Ranney. 1993. Considerations in implementing integrated biomass energy systems in developing countries. pp. 1855-1860. In First Biomass Conference of the Americas:
Energy, Environment, Agriculture, and Industry. National Renewable Energy Laboratory, Golden, Colorado.

Keywords: deforestation/ soils/ biomass resources

911. Perlack, R. D., J. W. Ranney, W. F. Barron, J. H. Cushman, and J. L. Trimble. 1986. Short-rotation intensive culture for the production of energy feedstocks in the U.S.: A review of experimental results and remaining obstacles to commercialization. Biomass 9:145-159. Keywords: commercialization/ short rotation intensive culture/ feedstocks

912. Perlack, R. D., J. W. Ranney, and M. Russell. 1991. Biomass Energy Development in Yunnan Province, China. ORNL/TM-11791. Oak Ridge National Laboratory, Oak Ridge, Tennessee. Keywords: biomass crops/ Yunnan Province, China/ economics/ production/ conversion technologies/ electricity

913. Perlack, R. D., J. W. Ranney, and L. L. Wright. 1992. Environmental Emissions and Socioeconomic Considerations in the Production, Storage, and Transportation of Biomass Energy Feedstocks. ORNL/TM-12030. Oak Ridge National Laboratory, Oak Ridge, Tennessee. Keywords: environmental effects/ economics/ crop management/ storage/ transportation/ production

914. Perlack, R. D. , M. E. Walsh, L. L. Wright, and L. D. Ostlie. 1996. The economic potential of whole-tree feedstock production. Bioresource Technology 55:223-229.

Keywords: economics/ whole-tree/ feedstocks/ short-rotation woody crops/ harvesting

915. Perlack, R. D., and L. L. Wright. 1995. Technical and economic status of wood energy feedstock production. Energy 20(4):279-284.

Keywords: economics/ biomass energy/ 
feedstocks/ production/ short rotation woody crops

916. Perlack, R. D., L. L. Wright, M. A. Huston, and W. E. Schramm. 1995.

Biomass Fuel from Woody Crops for Electric Power Generation. ORNL-6871.

Oak Ridge National Laboratory, Oak Ridge, Tennessee.

Keywords: biomass crops/ fuels/ shortrotation woody crops/ short rotation woody crops/ Hawaii/ Brazil/ Phillipines/ harvesting/ power generation/ transportation/ storage/ handling

917. Perry, C. H., K. N. Brooks, D. F. Grigal, J. G. Isebrands, and V. R.

Tolbert. 1998. A comparison of nutrient export from short-rotation hybrid poplar plantations and natural forest stands. pp. 1252-1261. In Bioenergy '98: Expanding Bioenergy Partnerships. Great Lakes Regional Biomass Energy Program, Chicago, Illinois.

Keywords: poplars, hybrid/ nutrient cycling/ nitrogen/ phosphorus/ environmental effects/ short rotation woody crops/ short rotation woody crops

918. Perry, C. H., D. F. Grigal, J. G. Isebrands, and V. R. Tolbert. 1998. Carbon sequestration in northwestern Minnesota's agricultural landscapes. pp. 298. In Agronomy Abstracts.

Keywords: carbon sequestration/ Minnesota/ agriculture

919. Perry, C. H., R. C. Miller, and K. N. Brooks. 1998. Hydrological implications of introducing hybrid poplars in Minnesota's farmlands. In International Conference on the Science of Managing Forests to Sustain Water Resources.

Keywords: poplars, hybrid/ hydrology/ land/ Minnesota

920. Perry, C. H., R. C. Miller, and K. N. Brooks. 2001. Impacts of short-rotation hybrid poplar plantations on regional water yield. Forest Ecology and Management 143:143-151.
Keywords: short rotation woody crops/ water yield/ hydrology/ afforestation/ agroforestry/ land use

921. Peterson, C. L. 1985. Vegetable oil as a diesel fuel: Status and research priorities. pp. 28. In 1985 Summer Meeting American Society of Agricultural Engineers. American Society of Agricultural Engineers, St. Joseph, Michigan.

Keywords: oils, vegetable/ diesel fuels/ fuels, biodiesel

922. Peterson, C. L., D. L. Auld, and R. A. Korus. 1988. Use of Vegetable Oil as a Fuel in Time of Emergency. Miscellanous Series No. 111. University of Idaho, Agricultural Experiment Station, Moscow, Idaho.

Keywords: oils, vegetable/ fuels

923. Peterson, C. L., R. A. Korus, D. L. Auld, and K. A. Mahler. 1990. Alcohol esters of rapeseed oil (AERO) as a fuel to reduce emissions of diesel engines. pp. 13. In Proceedings of the International Canola Conference. Potash and Phosphate Institute, Potash and Phosphate Institute of Canada (Saskatoon, Saskatchewan), and Foundation for Agronomic Research, Atlanta, Georgia.

Keywords: esters/ rapeseed/ fuels/ emissions/ diesel fuels

924. Pezeshki, S. R., and T. M. Hinckley. 1988. Water relations characteristics of Alnus rubra and Populus trichocarpa: Responses to field drought. Canadian Journal of Forest Research 18:1159-1166. Keywords: alders/ cottonwoods/ stomata/ roots/ osmotic potential/ senescence/ survival rate

\section{Pezeshki, S. R., and C. D. Oliver.}

1985. Early growth patterns of red alder and black cottonwood in mixed species plantations. Forest Science 31:190-200. Keywords: Alnus rubral Populus trichocarpa/ growth patterns/ leaf area/ biomass crops 
926. Pfeifer, R. A. , G. W. Fick, D. J. Lathwell, and C. Maybee. 1990.

Screening and Selection of Herbaceous Species for Biomass Production in the Midwest/Lake States. Final Report 19851989. ORNL/Sub/85-27410/5. Oak Ridge National Laboratory, Oak Ridge, Tennessee. Keywords: species selection/ soil types/ yields/ fiber/ nitrogen/ ash content

927. Phelps, J. E., J. G. Isebrands, D. W. Einspahr, J. B. Crist, and J. A. Sturos. 1985. Wood and paper properties of vacuum airlift segregated juvenile poplar whole-tree chips. Wood and Fiber Science 17:529-539.

Keywords: Populus tristis/ short rotation intensive culture/ beneficiation/ pulp, kraft/ quality/ whole-tree/ scanning electron microscopy/vacuum airlift segregation

928. Phelps, J. E., J. G. Isebrands, and R. M. Teclaw. 1983. Raw material evaluations of short rotation intensively cultured Populus coppice. pp. 46. In Abstracts of the International Union of Forestry Research Organizations Division 5 Conference. International Union of Forestry Research Organizations, Madison, Wisconsin.

Keywords: poplars/ coppice/ composition

929. Phelps, J. E., J. G. Isebrands, and R. M. Teclaw. 1987. Raw material quality of short-rotation. II. Wood and bark from first rotation stems and stems grown from coppice. International Association of Wood Anatomists (IAWA) Bulletin N.s. 8:182-186. Keywords: poplars, hybrid/ specific gravity/ fiber/ coppice/ composition

930. Phillips, D. R., M. G. Messina, A. Clark III, and D. J. Frederick. 1989. Nutrient content prediction equations for wetland trees in the U.S. Southern Coastal Plain. Biomass 19:169-187.

Keywords: nitrogen/ phosphorus/ potassium/ calcium/ magnesium/ bottomlands/ hardwoods/ biomass crops/ nutrition/ composition, chemical
931. Phipps, H. M. 1978. Rooting

Populus cuttings in various media bound with a liquid polymer. Plant Propagation 24:11-13.

Keywords: roots/ poplars/ harvesting/ polymers, liquid

932. Phipps, H. M. 1981. Increasing the production of greenwood cutting material of Populus hybrids with the cytokinin, ACCEL. Plant Propagation 27:8-10. Keywords: greenwood cutting/ poplars, hybrid/ cytokinin/ stock plants/ clonal propagation

933. Phipps, H. M., E. A. Hansen, and A. S. Fege. 1983. Pre-Plant Soaking of Dormant Populus Hardwood Cuttings. NC241. U.S. Forest Service, North Central Forest Experiment Station, St. Paul, Minnesota.

Keywords: clonal propagation/ poplars, hybrid/ establishment/ regeneration/ poplars

934. Phipps, H. M., E. A. Hansen, and D. N. Tolsted. 1980. Rooting greenwood tip cuttings of several Populus clones hydroponically (hydroponic rooting of Populus cuttings). Canadian Journal of Forest Research 10:107-110.

Keywords: clonal propagation/ Populus/ greenwood cutting/ roots

935. Phipps, H. M., and D. A. Netzer. 1981. The influence of collection time and storage temperature on Populus hardwood cutting development. Tree Planters' Notes 32:33-36.

Keywords: storage/ poplars/ hardwoods/ clonal propagation

936. Pimentel, D., and J. R. Krummel. 1987. Biomass energy and soil erosion: Assessment of resource costs. Biomass 14:15-38.

Keywords: erosion/ water availability/ corn stover/ energy crops, herbaceous/ short rotation woody crops/ energetics

937. Pinkerton, L. R., and G. G. Naughton. 1985. Growing Your Own 
Firewood. Revised Bulletin L-724. Kansas State University, Manhattan, Kansas.

Keywords: fuelwood/ biomass resources

938. Pinon, J., G. Newcombe, and G. A. Chastagner. 1994. Identification of races of Melampsora larici-populina, the Eurasian poplar leaf rust fungus, in California and Washington. Plant Disease 78:101. Keywords: Melampsora larici-populinal poplars/ rusts/ diseases

939. Pokorny, F. A., and H. Y. Wetzstein. 1984. Internal porosity, water availability, and root penetration of pine bark particles. Journal of Horticultural Science 19:447449.

Keywords: pines/ water availability/ quality

940. Pope, P. E. 1980. Site and fertilization influence biomass accumulation and nutrient content in black locust (Robinia pseudoacacia L.) plantations. pp. 205. In Agronomy Abstracts of 1980 Annual Meetings. American Society of Agronomy, Crop Science Society, and American Soil Science Society of America, Detroit, Michigan.

Keywords: fertilization/ biomass/ nutrients/ locusts, black

941. Pope, P. E. 1980. Woody crops and residues. pp. 29-45. In Proceedings of Intrauniversity 'Energy from Biomass' Workshop. 80-4. Purdue University, West Lafayette, Indiana.

Keywords: woody crops/ residues/ biomass crops/ resources

942. Pope, P. E., and J. D. Rhodes. 1981. Proceedings of the First Biennial Southern Silvicultural Research Conference. SO-34. J. P. Barnett (ed.). U.S. Forest Service, New Orleans, Louisiana.

Keywords: site characteristics/ crop management/ dry matter/ biomass crops/ locusts, black/ fertilization

943. Prakash, C. S., and B. A. Thielges. 1989. Interaction of geographic isolates of Melampsora meusae and Populus: Effect of temperature. Canadian Journal of Botany 67:486-490.

Keywords: Populus deltoides/ rusts/ diseases/ Melampsora medusae

944. Prakash, C. S., and B. A. Thielges. 1989. Somaclonal variation in eastern cottonwood for race-specific partial resistance to leaf rust disease.

Phytopathology 79:805-808.

Keywords: Populus deltoides/ Melampsora medusae/ breeding/ tissue culture/ diseases/ rusts

945. Pratt, D. C., D. R. Dubbe, E. G. Garver, and W. C. Johnson. 1988. Cattail (Typha spp.) Biomass Production: Stand Management and Sustainable Yields. ORNL/Sub/84-89674/1. Oak Ridge National Laboratory, Oak Ridge, Tennessee. Keywords: cattails/ crop management/ productivity

946. Preece, J. E., and C. A. Huetteman. 1993. An axillary shoot proliferation laboratory exercise-micropropagating Ajuga reptans. HortScience 28:156.

Keywords: clonal propagation/ cytokinin/ tissue culture/ shoots/ greenhouse

947. Preece, J. E., C. A. Huetteman, C. A. Ashby, D. F. Bresnan, and P. L. Roth. 1988. Provenance tests for biomass production using micropropagated clonal silver maple. HortScience 23:603.

Keywords: Acer/ provenance trials

948. Preece, J. E., C. A. Huetteman, W. C. Ashby, and P. L. Roth. 1991. Micro- and cutting propagation of silver maple. I. Results with adult and juvenile propagules. Journal of American Society for Horticultural Science 116:142-148. Keywords: Acer saccharinum/ tissue culture/ thidiazuron/ clonal propagation/ maples, silver

949. Preece, J. E., C. A. Huetteman, C. H. Puello, and M. C. Neuman. 1987. The influence of thidiazuron on in vitro culture of woody plants. HortScience 22:259. 
Keywords: clonal propagation/ thidiazuron/ woody crops

950. Pregitzer, K. S., D. I. Dickmann, R. L. Hendrick, and P. V. Nguyen. 1990. Whole-tree carbon and nitrogen partitioning in young hybrid poplars. Tree Physiology 7:79-93.

Keywords: biomass crops/ nitrogen/ photosynthesis/ roots/ poplars

951. Purnell, R. C., and R. C. Kellison. 1983. A tree improvement program for southern hardwoods. pp. 90-98. In Proceedings, 17th Southern Forest Tree Improvement Conference. University of Georgia, Athens, Georgia.

Keywords: hardwoods/ tree improvement

952. Purnell, R. C., and R. C. Kellison. 1987. A tree improvement programme for southern hardwoods. pp. 72-76. In Forest Genetic Resources Information No. 15. FAO, Rome, Italy.

Keywords: hardwoods/ tree improvement

953. Radcliffe, R. C., E. D. Matson, and J. A. Mattson. 1981. Tree-planting interval indicator. Tree Planters' Notes 32:13-14.

Keywords: short rotation intensive culture/ establishment

954. Radwan, M. A. 1987. Effects of Fertilization on Growth and Foliar Nutrients of Red Alder Seedlings. PNW-RP-375. U.S. Forest Service, Pacific Northwest Research Station, Portland, Oregon. Keywords: fertilization/ alders/ nutrient management

955. Radwan, M. A., and D. S. DeBell. 1981. Germination of Red Alder Seed. PNW-370. U.S. Forest Service, Pacific Northwest Forest and Range Experiment Station, Seattle, Washington. Keywords: germination/ alders/ seed/ stratification/ Alnus rubra

956. Radwan, M. A., and D. S. DeBell. 1988. Nutrient relations in coppiced black cottonwood and red alder. Plant and Soil 106:171-177.

Keywords: Alnus rubral Populus

trichocarpa/ nutrients/ coppice

957. Radwan, M. A., and D. S. DeBell. 1988. Phosphorus fertilizer and growth of red alder seedlings in waterlogged soil.

Northwest Science 62:29.

Keywords: Alnus/ fertilization/ growth/ soils/ site characteristics/ yields/ waterlogged soils

958. Radwan, M. A., and D. S. DeBell. 1988. Soil waterlogging, phosphorus, and growth of red alder seedlings. Plant Physiology (Suppl.) 86:546.

Keywords: Alnus/ fertilization/ growth/ soils/ site characteristics/ yields/ waterlogged soils/ phosphorus

959. Radwan, M. A., C. A. Harrington, and J. M. Kraft. 1984. Litterfall and nutrient returns in red alder stand in western Washington. Plant and Soil 79:343-351. Keywords: Alnus rubra/ aluminum/ economics/ leaf fall/ leaf litter/ nitrogen/ nutrients/ alders

960. Radwan, M. A., J. M. Kraft, and D. S. DeBell. 1987. Bud Characteristics of Unrooted Stem Cuttings Affect Establishment Success of Cottonwood. PNW-RN-461. U.S. Forest Service, Pacific Northwest Research Station, Olympia, Washington.

Keywords: clonal propagation/ genotypes/ cottonwoods/ Populus trichocarpa

961. Ranney, J. W. 1986. New technologies in the production of woody crops for energy in the United States. pp. 387-438. In Advances in Solar Energy: An Annual Review of Research and Development. K. W. Ber (ed.). American Solar Energy Society, Inc.; Plenum Press, New York.

Keywords: woody crops/ energy crops/ energy 
962. Ranney, J. W. 1992. Environmental considerations in biomass resource management for a greenhouse-constrained society. pp. 519-546. In Proceedings from the Technologies for a GreenhouseConstrained Society. M. A. Kuliasha, A. Zucker, and K. J. Ballew (eds.). Lewis Publishers, Chelsea, Michigan.

Keywords: environmental effects/ biomass crops/ greenhouse/ deforestation/ fuels/ pollution/ climate

963. Ranney, J. W., M. C. Bruner, and J. B. Levenson. 1981. The importance of edge in the structure and dynamics of forest islands. pp. 67-95. In Forest Island Dynamics in Man-Dominated Landscapes. Volume 41 of Ecological Studies. SpringerVerlag, New York.

Keywords: border effects/ forests/ environmental effects/ edge effect

964. Ranney, J. W., and J. H. Cushman. 1980. Regional evaluation of woody biomass production for fuels in the Southeast. pp. 109-120. In Biotechnology and Bioengineering Symposium No. 10. John Wiley \& Sons, Inc., New York. Keywords: regional analysis/ biomass crops/ Southeast/ land/ productivity/ wood biomass

965. Ranney, J. W., and J. H. Cushman. 1980. Silvicultural options and constraints in the production of wood energy feedstocks. pp. 10. In Proceedings, Bioenergy '80 Exposition. BioEnergy Council, Washington, DC.

Keywords: silviculture/ feedstocks/ woody crops/ economics/ energy/ environmental effects/species selection/ regional analysis

966. Ranney, J. W., and J. H. Cushman. 1982. Short-rotation woody crops as a source of energy. pp. 1391-1399. In Proceedings, Ninth Energy Technology Conference. Energy Efficiency in the Eighties. R. F. Hill (ed.). Government Institutes, Inc., Rockville, Maryland. Keywords: short rotation woody crops/ biomass crops/ feedstocks/ short rotation intensive culture/ genetics

967. Ranney, J. W., and J. H. Cushman. 1982. Short Rotation Woody Crops

Program: Annual Progress Report for 1981. ORNL/TM-8120. Oak Ridge National Laboratory, Oak Ridge, Tennessee. Keywords: short rotation woody crops/ species selection/ economics/ environmental effects

968. Ranney, J. W., and J. H. Cushman. 1990. Energy from biomass. pp. 299-311. In The Energy Sourcebook: A Guide to Technology, Resources and Policy. R. Howes and A. Fainberg (eds.). American Institute of Physics, New York. Keywords: biomass crops/ biofuels/ breeding/ biotechnology/ economics/ conversion technologies

969. Ranney, J. W., R. J. Dinus, and A. F. Turhollow. 1990. Manipulation of wood chemical traits for energy: An assessment. pp. 33-47. In Proceedings, Workshop for Improvement of Feedstock Quality. University of Toronto Publishers, Toronto, Canada.

Keywords: quality/ composition, chemical/ woody crops/ lignin/ cellulose/ hemicellulose/ specific gravity/ ash content

970. Ranney, J. W., A. R. Ehrenshaft, P. A. Layton, W. A. McNabb, and L. L. Wright. 1988. Short Rotation Woody Crops Program Annual Progress Report for 1987. ORNL-6440. Oak Ridge National Laboratory, Oak Ridge, Tennessee. Keywords: species selection/ growth/ productivity/ poplars/ economics/ clonal variations/ short rotation woody crops/ environmental effects

971. Ranney, J. W., and L. K. Mann. 1994. Environmental considerations in energy crop production. Biomass and Bioenergy 6(3):211-228.

Keywords: energy crops/ environmental effects/ biomass crops/ fertilization/ air quality/ pests/ productivity/ wastes/ erosion 
972. Ranney, J. W., R. D. Perlack, J. L. Trimble, and L. L. Wright. 1985.

Specialized hardwood crops for energy and fiber: Status, impact, and need. TAPPI 68:36-41.

Keywords: hardwoods/ fiber/ forest products/ fuels/ silviculture/ genetics/ biotechnology/ forestry

973. Ranney, J. W., and J. L. Trimble. 1982. The Short Rotation Woody Crops Program: 1982 Program Summary. ORNL5916. Oak Ridge National Laboratory, Oak Ridge, Tennessee.

Keywords: short rotation woody crops/ environmental effects/ species selection/ economics

974. Ranney, J. W., J. L. Trimble, L. L. Wright, J. H. Cushman, and C. R. Wenzel. 1984. Short Rotation Woody Crops Program: Annual Progress Report for 1983. ORNL-6085. Oak Ridge National Laboratory, Oak Ridge, Tennessee.

Keywords: environmental effects/ short rotation woody crops/ species selection/ economics

975. Ranney, J. W., J. L. Trimble, L. L. Wright, P. A. Layton, R. D. Perlack, C. R. Wenzel, and D. T. Curtin. 1986. Short Rotation Woody Crops Program: Annual Progress Report for 1985. ORNL-6254. Oak Ridge National Laboratory, Oak Ridge, Tennessee.

Keywords: environmental effects/ short rotation woody crops/ species selection/ economics

976. Ranney, J. W., J. L. Trimble, L. L. Wright, and R. D. Perlack. 1986.

Research on short-rotation woody crops in the South. pp. 71-84. In Proceedings from the Third Biomass Energy Research Conference. W. H. Smith (ed.). Plenum Press, New York.

Keywords: short rotation woody crops/ species selection/ feedstocks

977. Ranney, J. W., L. L. Wright, and P. A. Layton. 1987. Hardwood energy crops: The technology of intensive culture. Journal of Forestry 85:17-28.

Keywords: short rotation intensive culture/ productivity/ crop management/ biofuels/ economics/ weed control/ planting density/ rotation length/ genetic modification

978. Ranney, J. W., L. L. Wright, P. A. Layton, W. A. McNabb, C. R. Wenzel, and D. T. Curtin. 1987. Short Rotation Woody Crops Program: Annual Progress Report for 1986. ORNL-6348. Oak Ridge National Laboratory, Oak Ridge, Tennessee. Keywords: short rotation woody crops/ species selection/ economics/ environmental effects

979. Ranney, J. W., L. L. Wright, and C. P. Mitchell. 1991. Carbon storage and recycling in short-rotation energy crops. pp. 39-60. In Proceedings, Bioenergy and the Greenhouse Effect. C. P. Mitchell (ed.). International Energy Agency and National Energy Administration of Sweden, Stockholm, Sweden.

Keywords: greenhouse/ climate/ environmental effects/ carbon sequestration

980. Ranney, J. W., L. L. Wright, and R. D. Perlack. 1993. Strategic role and risks of energy crops in utility power. pp. 2.23-2.32. In Proceedings: Strategic Benefits of Biomass and Waste Fuels. Electric Power Research Institute, Pleasant Hill, California.

Keywords: energy crops/ electricity/ economics/ environmental effects

981. Ranney, J. W., L. L. Wright, J. L. Trimble, R. D. Perlack, D. H. Dawson, C. R. Wenzel, and D. T. Curtin. 1985. Short Rotation Woody Crops Program: Annual Progress Report for 1984. ORNL6160. Oak Ridge National Laboratory, Oak Ridge, Tennessee.

Keywords: short rotation woody crops/ species selection/ economics/ environmental effects

982. Rauscher, H. M. 1994. The role of expert and hypertext systems in modeling 
root-shoot interactions and carbon allocation. pp. 219-243. In Biology of Adventitious Root Formation. T. D. Davis and B. E. Haissig (eds.). Plenum Press, New York.

Keywords: models/ root-shoot interactions/ carbon

983. Rauscher, H. M., and J. G. Isebrands. 1990. Using expert systems to model tree development. pp. 129-138. In Proceedings, Forest Simulation Systems. L. C. Wensel and G. S. Biging (eds.). Bulletin 1927. University of California, Berkeley, California.

Keywords: models/ biomass crops/ growth/ poplars

984. Rauscher, H. M., J. G. Isebrands, T. R. Crow, R. E. Dickson, D. I. Dickmann, and D. A. Michael. 1988. Simulating the influence of temperature and light on the growth of juvenile poplars in their establishment year. pp. 331-338. In Forest Growth Modelling and Prediction. NC-120. U.S. Forest Service, North Central Forest Experiment Station, Rhinelander, Wisconsin.

Keywords: models/ biomass crops/ growth/ poplars

985. Rauscher, H. M., J. G. Isebrands, G. E. Host, R. E. Dickson, D. I. Dickmann, T. R. Crow, and D. A. Michael. 1990. ECOPHYS: An ecophysiological growth process model for juvenile poplar. Tree Physiology 7:255-281. Keywords: poplars/ growth/ radiation, solar/ temperature/ models, ECOPHYS

986. Rauscher, H. M., J. G. Isebrands, G. E. Host, R. E. Dickson, D. I. Dickmann, T. R. Crow, and D. A. Michael. 1992. ECOPHYS: An ecophysiological growth process model for juvenile poplar. The Forestry Chronicle 68:221.

Keywords: ecophysiology/ poplars/ models, ECOPHYS/ clonal propagation/

photosynthesis/ genetics
987. Rauscher, H. M., D. A. Michael, J. G. Isebrands, D. Dickson, T. R. Crow, and D. I. Dickmann. 1986. Exploring the growth of a poplar seedling as influenced by genetics and climate. pp. 738. In Proceedings, Forestry Microcomputer Software Symposium. H. V. Wiant, D. O. Yandle, and W. E. Kidd (eds.). West Virginia University, College of Agriculture and Forestry, Morgantown, West Virginia. Keywords: poplars/ models, growth/ climate/ genetics/growth responses

988. Rawanski, J. J., J. A. Bowles, and N. V. Noste. 1980. Soil Properties Relate to Conifer Seedling Height Growth in Northern Wisconsin. NC-254. U.S. Forest Service, North Central Forest Experiment Station, Rhinelander, Wisconsin.

Keywords: soil properties/ conifers/ growth patterns

989. Raymer, P. L., D. G. Bullock, and D. L. Thomas. 1988. Potential of winter and spring rapeseed cultivars for oilseed production in the southeastern U.S.A. pp. 5. In Proceedings of the First National Symposium, New Crops. Purdue University, West Lafayette, Indiana.

Keywords: rapeseed/ oilseeds/ South/ Brassica napus

990. Raymer, P. L., R. A. Harris, D. A. Wyatt, J. Bradley, J. Brown, W. T. Fike, A. N. Hang, C. H. Hovermale, P. L. Mask, P. M. Porter, D. E. Starner, H. D. Sunderman, and L. E. Welty. 1993. United States National Rapeseed/Canola Variety Trial 1991-92. Special Publication Number 84. University of Georgia, Griffin, Georgia.

Keywords: rapeseed/ canola

991. Reddy, K. V. 1985. Effect of inbreeding on estimates of genetic parameters in Eucalyptus grandis. In Proceedings, Eighteenth Southern Forest Tree Improvement Conference. R. C. Schmidtling and M. M. Griggs (eds.). U.S. Forest Service, Southern Forest Experiment Station, Gulfport, Mississippi. 
Keywords: Eucalyptus grandis/ genetic variations/ inbreeding

992. Reddy, K. V., and D. L. Rockwood. 1986. Genetic factors influencing coppice success of eucalypts in Florida. pp. 303309. In Proceedings, Ninth North American Forest Biology Workshop. Oklahoma State University, Stillwater, Oklahoma. Keywords: Eucalyptus/ coppice/ cold hardiness/ short rotation woody crops/ genetic correlations

993. Reddy, K. V., and D. L. Rockwood. 1989. Breeding strategies for coppice production in a Eucalyptus grandis base population with four generations of selection. Silvae Genetica 38:148-151. Keywords: Eucalyptus grandis/ genetic variations/ cold hardiness/ heritability/ inbreeding/ genetic modification/ provenance trials

994. Reddy, K. V., D. L. Rockwood, C. W. Comer, and G. F. Meskimen. 1985. Predicted genetic gains adjusted for inbreeding for a Eucalyptus grandis seed orchard. pp. 283-289. In Proceedings, Eighteenth Southern Forest Tree Improvement Conference. R. C. Schmidtling and M. M. Griggs (eds.). U.S. Forest Service, Southern Forest Experiment Station, Gulfport, Mississippi.

Keywords: Eucalyptus grandis/ heritability/ inbreeding/ breeding

995. Reddy, K. V., D. L. Rockwood, C. W. Comer, and G. F. Meskimen. 1986. Genetic improvement of Eucalyptus grandis for biomass production in Florida. pp. 103110. In Proceedings, Third Southern Biomass Energy Research Conference. University of Florida, Gainesville, Florida. Keywords: Eucalyptus grandis/ cold hardiness/ heritability/ genetic modification/ genetic correlations/ coppice/ energy crops

996. Reddy, K. V., D. L. Rockwood, and G. F. Meskimen. 1986. A strategy for conversion of an Eucalyptus grandis base population into a seedling orchard. pp. 613-
621. In Proceedings, Breeding Theory, Progeny Testing, and Seed Orchards. International Union of Forestry Research Organizations, Ljubljana, Yugoslavia. Keywords: Eucalyptus grandis/ seedlings

997. Redfearn, D. D., K. J. Moore, K. P. Vogel, and et al. 1997. Canopy architecture and morphology of switchgrass populations differing in forage yield. Agronomy Journal 89(2):262-269. Keywords: canopy/ morphology/ switchgrass/ Panicum virgatum/ forage crops

998. Redfearn, D. D., K. J. Moore, K. P. Vogel, W. Waller, and R. B. Mitchell. 1999. Fiber digestion dynamics of sward components with switchgrass populations. Crop Science 39:784-789.

Keywords: fiber/ sward components/ switchgrass/ Panicum virgatum

999. Reed, R. L., M. A. Sanderson, V. G. Allen, and A. G. Matches. 1999. Growth and cadmium accumulation in selected switchgrass cultivars. Communications in Soil Science and Plant Analysis 30:26552667.

Keywords: growth/ cadmium/ switchgrass

1000. Reed, R. L., M. A. Sanderson, V. G. Allen, and R. E. Zartman. 2002.

Cadmium application and $\mathrm{pH}$ effects on growth and cadmium accumulation of switchgrass. Commun. Soil Science Plant Anal. 33(7\&8):1187-1203.

Keywords: switchgrass/ biosolids/ sludge/ $\mathrm{pH} /$ cadmium

1001. Reed, R. L., M. A. Sanderson, M. A. Hussey, W. R. Ocumpaugh, J. C. Read, C. R. Tischler, and B. A. Young. 1994. Forage Research in Texas, 1993. CPR-5078-5102. R. M. Jones (ed.). Texas A\&M, Kingsville, Texas.

Keywords: switchgrass/ Panicum virgatum/ biomass crops/ crop management/ establishment 
1002. Reed, R. L., M. A. Sanderson, M. A. Hussey, W. R. Ocumpaugh, J. C. Read, C. R. Tischler, and B. A. Young. 1994. Switchgrass management for biomass in the south-central U.S. pp. 47-56. In Liquid Fuels, Lubricants and Additives from Biomass. B. E. Dale (ed.). American Society of Agricultural Engineers, St. Joseph, Michigan.

Keywords: biomass crops/ crop management/ fertilization/ Panicum

virgatum/ switchgrass

1003. Reichenbacker, R. R., and E. R. Hart. 1993. Impact of artificial defoliation on Populus growth and biomass production. In The Third North American Agroforestry Conference: Opportunities for Agroforestry in the Temperate Zone Worldwide. Iowa State University, Ames, Iowa. Keywords: agroforestry/ defoliation/ poplars/ growth/ biomass crops

1004. Reichenbacker, R. R., R. C. Schultz, and E. R. Hart. 1996. Artificial defoliation effect on Populus growth, biomass production, and total nonstructural carbohydrate concentration. Environmental Entomology 25(3):632-642.

Keywords: Chrysomela scripta/ Populus/ defoliation/ biomass crops/ productivity/ growth responses/ carbohydrates/ cottonwoods

1005. Reighard, G. L. 1985 . Genetic and cultural factors affecting growth performance of slash pine. pp. 100-106. In Proceedings, Eighteenth Southern Forest Tree Improvement Conference. R. C. Schmidtling and M. M. Griggs (eds.). U.S. Forest Service, Southern Forest Experiment Station, Gulfport, Mississippi.

Keywords: pinesgrowth responses/ genetic variations/ crop management

1006. Reighard, G. L., G. T. Howe, and J. W. Hanover. 1985. Effects of chemical weed control and seedling planting depth on survival and growth of aspen. Tree

Planters' Notes 36:3-7.
Keywords: aspens/ weed control/ seedlings/ Populus grandidentatal Populus tremuloides

1007. Reighard, G. L., and D. L. Rockwood. 1985. Plot subsampling in intensively cultured slash and sand pine tests. pp. 27-30. In Proceedings, Seventh Southern Forest Biomass Workshop. D. L. Rockwood (ed.). University of Florida, Gainesville, Florida.

Keywords: Pinus elliottii/ pines/ Pinus clausa

1008. Reisinger, T. W., and R. A. Kluender. 1983. Storage and Handling of Whole Tree Chips and Residues for Fuel. Publication No. 83A2. American Pulpwood Association, Southwide Energy Committee, Washington, DC.

Keywords: storage/ handling/ whole-tree/ residues/ resource assessment

1009. Reynolds, J. H., C. L. Walker, and M. J. Kirchner. 2000. Nitrogen removal in switchgrass biomass under two harvest systems. Biomass and Bioenergy 19:281286.

Keywords: nitrogen/ Panicum virgatum./ energy crops, herbaceous/ biomass crops

1010. Reynolds, J. H., C. L. Walker, G. V. Wilson, and J. Logan. 1996.

Switchgrass yields and soil water trends under two biomass harvest systems. pp. 1015. In Liquid Fuel and Industrial Products from Renewable Resources. J. S. Cundiff, E. E. Gavett, C. Hansen, C. Peterson, M. A. Sanderson, H. Shapouri, and D. L. VanDyne (eds.). The American Society of Agricultural Engineers, St. Joseph, Michigan.

Keywords: feedstocks/ forage crops/ grasses/ switchgrass/ Panicum virgatum/ water availability/ harvesting

1011. Ridge, C. R., T. M. Hinckley, R. F. Stettler, and E. Van Volkenburgh. 1986. Leaf growth characteristics of fast growing hybrids (Populus trichocarpa $\times P$. deltoides). Tree Physiology 1:209-216. 
Keywords: Populus trichocarpal Populus deltoides/ leaf development

1012. Riekerk, H. 1982. Environmental impacts of intensive silviculture in Florida. In Symposium on Forest Site and Continuous Productivity. S. P. Gessel and R. Ballard (eds.). U.S. Forest Service, Pacific Northwest Research Station, Seattle, Washington.

Keywords: silviculture/ biomass crops/ environmental effects

1013. Riekerk, H., L. F. Conde, J. C. Hendrickson, and W. S. Gain. 1980. Research on environmental and site effects of forest management practices in the lower coastal plain. pp. 331-339. In Proceedings of the First Biennial Southern Silvicultural Research Conference. J. P. Barnett (ed.). SO-34. U.S. Forest Service, Southeastern Forest Experiment Station, Asheville, North Carolina.

Keywords: crop management/ forests/ environmental effects/ silviculture/ fuelwood/ short rotation woody crops/ pulpwood/ Eucalyptus

1014. Riekerk, H., J. C. Hendrickson, and W. S. Gain. 1981. Site and environmental effects of tree biomass silviculture. pp. 1581-1591. In Proceedings, 1981 International Gas Research Conference. University of Florida, Gainesville, Florida.

Keywords: pines/ Eucalyptus/ soil properties/ environmental effects/ Casuarina/ nutrients/ weed control

1015. Riemenschneider, D. E. 1994.

Genomic manipulation of plant materials for adventitious rooting research. pp. 61-76. In First International Symposium on the Biology of Adventitious Root Formation. T. D. Davis and B. E. Haissig (eds.). NC154. Plenum Press, New York.

Keywords: genomic manipulation/ roots/ roots/ genotypes

1016. Riemenschneider, D. E. 1996. Quantitative genetic analysis of adventitious root forming ability in Populus trichocarpa. pp. 8. In Second International Symposium on Adventitious Rooting. Hebrew University of Jerusalem, Jerusalem, Israel. Keywords: genetic variations/ roots/ Populus trichocarpa

1017. Riemenschneider, D. E. 1997. Fast growing trees (fuel and pulpwood). pp. 510. In Farming the Floodplain: The Potential for Flood Tolerant Floodplain Uses. The Wetlands Initiative, Chicago, Illinois.

Keywords: floodplain/ fuels/ pulpwood/ forests

1018. Riemenschneider, D.E. 1997. Genetic engineering of horticultural and forestry crops for herbicide tolerance. pp. 367-384. In Biotechnology of Ornamental Plants. R. L. Geneve, J. E. Preece, and S. A. Merkle (eds.). CAB International. Keywords: genetics/ horticulture/ forestry/ herbicides/ biotechnology

1019. Riemenschneider, D. E., and E. O. Bauer. 1997. Quantitative genetic analysis of adventitious root forming ability in Populus trichocarpa (Torr Et. Gray). pp. 193-202. In Biology of Root Formation and Development. Altman and Waisel (eds.). Plenum Press, New York. Keywords: genetic variations/ roots/ Populus trichocarpa

1020. Riemenschneider, D. E., W. E. Berguson, D. I. Dickmann, R. B. Hall, J. G. Isebrands, C. A. Mohn, G. R. Stanosz, and G. A. Tuskan. 2001. Poplar breeding and testing strategies in the northcentral U.S.: Demonstration of potential yield and consideration of future research needs. The Forestry Chronicle 77(2):11. Keywords: Populus/ biomass crops/ multitrait selection/ genotypes

1021. Riemenschneider, D. E., B. E. Haissig, and E. T. Bingham. 1988. Integrating biotechnology and conventional breeding in plant breeding programs. pp. 433-449. In Genetic Manipulation of 
Woody Plants. J. W. Hanover and D. Keathley (eds.). Plenum Press, New York. Keywords: biotechnology/ genetic modification/ breeding

1022. Riemenschneider, D. E., B. E. Haissig, J. C. Sellmer, and J. J. Fillatti. 1988. Expression of a herbicide tolerance gene in young plants of a transgenic hybrid poplar clone. pp. 73-80. In Somatic Cell Genetics of Woody Plants. M. R. Ahuja (ed.). Kluwer Academic Publishers, The Netherlands.

Keywords: herbicides/ glyphosate/ herbicides/ Salmonella typhimerium/ poplars, hybrid/ Agrobacterium tumefaciens/ growth patterns

1023. Riemenschneider, D. E., and J. G. Isebrands. 1994. Physiological and genetic strategies for selecting poplar crop plants. pp. 69. In Abstracts of Papers and Posters Presented at the Annual Meetings and Joint Conference of the Western Forest Genetics Association. James River Corporation, Camas, Washington.

Keywords: genetic modification/ poplars/ selection

1024. Riemenschneider, D. E., and B. G. McMahon. 1993. Genetic variation among Lake States balsam poplar populations is associated with geographic origin. Forest Science 39:130-136.

Keywords: Populus/ phenology/ sylleptic branching/ cluster analysis

1025. Riemenschneider, D. E., B. G. McMahon, and M. E. Ostry. 1992. Use of selection indices to increase tree height and to control damaging agents in 2-year-old balsam poplar. Canadian Journal of Forest Research 22:561-567.

Keywords: growth/ poplars/ Populus/ phenology/ leaf development/ genetics/ phenotype/ clonal propagation/ sylleptic branching/ Septoria/ Melampsora/ rusts

1026. Riemenschneider, D. E., B. G. McMahon, and M. E. Ostry. 1994.

Population-dependent selection strategies needed for 2-year-old black cottonwood clones. Canadian Journal of Forest Research 24:1704-1710.

Keywords: populations/ cottonwoods/ clones/ Populus trichocarpa

1027. Riemenschneider, D. E., and D. A. Netzer. 1997. Intensive culture of hybrid poplars in Minnesota. pp. 53-58. In Proceedings of the First Conference of the Short Rotation Woody Crops Operations Working Group. Short Rotation Woody Crops Operations Working Group. Keywords: poplars, hybrid/ intensive culture

1028. Riemenschneider, D. E., H. E. Stelzer, and G. S. Foster. 1996.

Quantitative genetics of poplars and poplar hybrids. pp. 159-181. In Biology of Populus and its Implications for Management and Conservation. R. F. Stettler, Jr. H. D. Bradshaw, P. E. Heilman, and T. M. Hinckley (eds.). National Research Council, Canada.

Keywords: biology/ genetics/ poplars/ hybrids

1029. Rietveld, W. J., and R. W. Tinus. 1987. A simple method for evaluating whole-plant cold hardiness. Tree Planters' Notes 38:16-18.

Keywords: cold hardiness/ physiology/ cold hardiness/ stress

1030. Roberts, D. R., and S. B. Carpenter. 1980. Effects of cultural treatments on the establishment and initial growth of black locust on mine spoil for biomass production. pp. 15-17. In Symposium on Surface Mining Hydrology, Sedimentology and Reclamation. University of Kentucky, Lexington, Kentucky. Keywords: crop management/ growth/ locusts, black/ mined land/ biomass crops/ Robinia pseudoacacia/ seedlings/ fertilization/ vegetation, herbaceous

1031. Roberts, P. S., and J. Zavitkovski. 1980. Growth of Hybrid Poplars, White Spruce, and Jack Pine Under Various 
Artificial Lights. NC-206. U.S. Forest Service, North Central Forest Experiment Station, Duluth, Minnesota.

Keywords: poplars, hybrid/ spruces/ pines/ light

1032. Robison, D. J., L. P. Abrahamson, and E. H. White. 1994. Silviculture of wood biomass crops as an industrial energy feedstock. The New York Forest Owner 4-5. Keywords: silviculture/ wood biomass/ energy/ feedstocks/ willows/ agroforestry

1033. Robison, D. J., L. P. Abrahamson, E. H. White, and T. A. Volk. 1996. Biomass-for-bioenergy: A new agri-forest crop slated for commercialization. New York Forest Owner 6-7.

Keywords: biomass crops/ bioenergy/ agroforestry/ commercialization

1034. Robison, D. J., T. Rooney, L. P. Abrahamson, and E. H. White. 1994. Wood energy issues in New York. The New York Forest Owner 5.

Keywords: biomass energy/ carbon dioxide/ biomass crops/global change/ New York

1035. Rockwood, D. L. 1983. Alternative designs for progeny testing slash pine. pp. 179-185. In Proceedings, 17th Southern Forest Tree Improvement Conference. University of Georgia, Athens, Georgia. Keywords: pines/ progeny tests

1036. Rockwood, D. L. 1983. Biomass feedstocks: Improvement in quality and quantity through genetic selection and breeding. pp. 72-76. In Summary of the Southern Biomass Energy Research Conference. University of Alabama, Tuscaloosa, Alabama. Keywords: biomass crops/ productivity/ breeding/ genetic modification

1037. Rockwood, D. L. 1984. Genetic improvement potential for biomass quality and quantity. Biomass 6:37-45. Keywords: genetic modification/ quality/ productivity
1038. Rockwood, D. L. 1986.

Development of woody biomass cultural systems for Florida. pp. 85-94. In Biomass Energy Development. W. H. Smith (ed.). Plenum Press, New York.

Keywords: woody crops/ crop management

1039. Rockwood, D. L., C. W. Comer, L. F. Conde, D. R. Dippon, J. B. Huffman, H. Riekerk, and S. Wang. 1983. Energy and Chemicals from Woody Species in Florida. Final Report for the Period April 17, 1978-May 16, 1983. ORNL/Sub/819050/1. Oak Ridge National Laboratory, Oak Ridge, Tennessee.

Keywords: woody crops/ species selection/ by-products/ composition, chemical/ biomass resources

1040. Rockwood, D. L., C. W. Comer, D. R. Dippon, and J. B. Huffman. 1985. Woody Biomass Production Options for Florida. Technical Bulletin 856. University of Florida, Agricultural Experiment Station, Gainesville, Florida.

Keywords: woody crops/ crop management

1041. Rockwood, D. L., and L. F. Conde. 1983. Genetic variation for biomass production in Eucalyptus grandis.

Silvicultura (International Union of Forestry

Research Organizations Fast Growing Trees Symposium) 8:652-653.

Keywords: Eucalyptus grandis/ genetic variations

1042. Rockwood, D. L., L. F. Conde, and R. H. Brendemuehl. 1980. Biomass

Production of Closely Spaced Choctawhatchee Sand Pines. SE-293. U.S. Forest Service, Southeast Experiment Station, Asheville, North Carolina. Keywords: Pinus clausa/ biomass crops/ sandhills

1043. Rockwood, D. L., L. F. Conde, and R. F. Fisher. 1981. Maximizing woody biomass production in Florida. pp. 859-867. In Proceedings, 1981 International Gas Research Conference. University of Florida, Gainesville, Florida. 
Keywords: species selection/ pines/ Eucalyptus

1044. Rockwood, D. L., L. F. Conde, and J. B. Huffman. 1983. Utilization of Melaleuca quinquernervia for biomass production. Silvicultura (International Union of Forestry Research Organizations Fast Growing Trees Symposium) 8:375-376. Keywords: genetic modification/ productivity/ planting density/ biomass crops/Melaleuca

1045. Rockwood, D. L., and J. D. DeValerio. 1986. Promising species for woody biomass production in warm-humid environments. Biomass 11:17.

Keywords: genetic variations/ biomass crops/ Florida/ Eucalyptus/ Leucaena leucocephalal Liquidambar styraciflual Platanus occidentalis/ Sapium sebiferum

1046. Rockwood, D. L., and D. R. Dippon. 1987. Prospects for commercialization of Eucalyptus biomass plantations in Florida. pp. 233-249. In Proceedings, Energy from Biomass and Wastes X. D. L. Klass (ed.). Institute of Gas Technology, Chicago, Illinois.

Keywords: Eucalyptus/ commercialization/ crop management

1047. Rockwood, D. L., and D. R. Dippon. 1989. Biological and economic potentials of Eucalyptus grandis and slash pine as biomass energy crops. Biomass 20:155-165.

Keywords: Pinus elliottii/ biomass crops/ energy crops/ short rotation intensive culture/ soil types/ planting density/ Eucalyptus grandis

1048. Rockwood, D. L., D. R. Dippon, and C. W. Comer. 1984. Potential of Eucalyptus grandis for biomass production in Florida. Bioenergy 84:86-93.

Keywords: Eucalyptus grandis

1049. Rockwood, D. L., D. R. Dippon, and M. S. Lesney. 1988. Woody Species for Biomass Production in Florida. Final
Report 1983-1988. ORNL/Sub/81-09050/7. Oak Ridge National Laboratory, Oak Ridge, Tennessee.

Keywords: species selection/ woody crops

1050. Rockwood, D. L., and L. J.

Frampton, Jr. 1979. Genetic variation in sand pine and slash pine for energy production in silvicultural biomass plantations. pp. 156-165. In Proceedings, 15th Southern Forest Tree Improvement Conference. Mississippi State University, Biloxi, Mississippi.

Keywords: Pinus clausal Pinus elliottiil genetic variations/ pines/ energy/ silviculture/ biomass crops

1051. Rockwood, D. L., and T. F. Geary. 1982. Genetic variation in biomass productivity and coppicing of intensively grown Eucalyptus grandis in southern Florida. pp. 400-403. In Proceedings, 7th North American Forest Biology Workshop. University of Kentucky, Lexington,

Kentucky.

Keywords: GXE interaction/ stand density/ genetic variations/ yields/ coppice/

Eucalyptus grandis

1052. Rockwood, D. L., T. F. Geary, and P. S. Bourgeron. 1982. Planting density and genetic influences on seedling growth and coppicing of eucalypts in southern Florida. pp. 95-102. In Proceedings, 1982 Southern Forest Biomass Workshop. U.S. Forest Service, Southern Forest Experiment Station, New Orleans, Louisiana. Keywords: Eucalyptus/ soils/ planting density

1053. Rockwood, D. L., J. B Huffman, and L. F. Conde. 1983. Potential of Casuarina spp. for biomass production in Florida. Silvicultura (International Union of Forestry Research Organizations Fast Growing Trees Symposium) 8:376-377. Keywords: Casuarina equisetifolial Casuarina cunninghaminana/ Casuarina glauca/ biomass crops/ growth patterns 
1054. Rockwood, D. L., R. C. Kellison, E. C. Franklin, and G. F. Meskimen. 1986. Operational advanced generation improvement programs for minor species in the South. pp. 27-37. In Proceedings of a Workshop in Advanced Generation Breeding: Current Status and Research Needs. Bulletin 309. Louisiana Agricultural Experiment Station, Louisiana State University Agricultural Center, Southern Cooperative Series, Baton Rouge, Louisiana.

Keywords: Pinus taedal Pinus elliottiil Pinus palustris/ Pinus virginianal Pinus clausa/ regeneration/ progeny tests/ breeding/ provenance trials/ Eucalyptus grandis

1055. Rockwood, D. L., and G. M. Prine. 1988. Alternative production systems: Woody crops. pp. 277-289. In Methane: A Systematic Approach. W. H. Smith and J. R. Frank (eds.). Elsevier Science Publishers Ltd., London.

Keywords: species selection/ production systems

1056. Rockwood, D. L., K. V. Reddy, E. I. Warrag, and C. W. Comer. 1987. Development of Eucalyptus amplifolia for woody biomass production. Australian Forest Research 17:173-178.

Keywords: Eucalyptus/ coppice

1057. Rockwood, D. L., E. I. Warrag, J. Bryan, and K. Kratz. 1989. Recent advances in the development of Eucalyptus grandis for commercial planting in Southern Florida. pp. 317-326. In Proceedings, Fifth Biennial Southern Silvicultural Research Conference. J. H. Miller (ed.). U.S. Forest Service, Southern Forest Experiment Station, New Orleans, Louisiana. Keywords: Eucalyptus/ cold hardiness/ stems/ composition/ clonal propagation

1058. Rockwood, D. L., C. F. Windsor, and J. F. Hodges. 1983. Response of slash pine progenies to fertilization. Southern Journal of Applied Forestry 8:37-40. Keywords: pines/ fertilization
1059. Roden, J., E. V. Volkenburgh, and T. M. Hinckley. 1990. Cellular basis for limitation of poplar leaf growth by water deficit. Tree Physiology 6:611-219.

Keywords: poplars/ leaf development/ water relations

1060. Roeder, K. R., and D. L. Rockwood. 1982. Potential Stem Biomass and Energy Content Yields of Eucalyptus grandis and Eucalyptus robusta in South Florida. Technical Bulletin 831. University of Florida, Agricultural Experiment Station, Gainesville, Florida.

Keywords: prediction equations/ models/ Eucalyptus grandis/ Eucalyptus robusta

1061. Rogers, D. L., R. F. Stettler, and P. E. Heilman. 1989. Genetic variation and productivity of Populus trichocarpa and its hybrids. III. Structure and pattern of variation in a 3-year field test. Canadian Journal of Forest Research 19:372-377. Keywords: poplars/ hybrids/ genetic variations/ productivity

1062. Rose, D. W., K. D. Ferguson, D. C. Lothner, and J. Zavitkovski. 1981. An Economic and Energy Analysis of Poplar Intensive Cultures in the Lake States. NC196. U.S. Forest Service, North Central Forest Experiment Station, St. Paul, Minnesota.

Keywords: economics/ poplars/ intensive culture/ Lake States/ energy content

1063. Rose, D. W., B. Walker, K. D. Ferguson, and D. C. Lothner. 1981. A comparison of the energy efficiency of intensive and extensive hybrid poplar production systems. pp. 53-70. In Fuels from Biomass and Wastes. D. L. Klass and G. H. Emert (eds.). Ann Arbor Science Publishers, Ann Arbor, Michigan. Keywords: production systems/ energy balance

1064. Rottmann, W. H., R. Meilan, L. A. Sheppard, A. M. Brunner, J. S. Skinner, C. Ma, S. Chang, L. Jouanin, G. Pilate, and S. H. Strauss. 2000. Diverse effects of 
overexpression of LEAFY and PTLF, a poplar (Populus) homolog of LEAFY/FLORICAULA, in transgenic poplar and Arabidopsis. The Plant Journal 22(3):235-245.

Keywords: poplars/ Populus/ genes/ transgenic

1065. Rowell, C. E., and S. B. Carpenter. 1980. Evaluating and predicting black locust biomass production on reclaimed surface mines in Kentucky. pp. 405-411. In Symposium on Surface Mining Hydrology, Sedimentology and Reclamation. University of Kentucky, Lexington, Kentucky. Keywords: locusts, black/ biomass crops/ surface mines/ Kentucky/ Robinia pseudoacacia/ nitrogen fixation

1066. Royle, D. J., and M. E. Ostry. 1995. Disease and pest control in the bioenergy crops: Poplar and willow. Biomass and Bioenergy 9(1-5):69-79. Keywords: diseases/ pests/ biomass crops/ energy crops/ poplars/ willows/ rusts/ Melampsora/ Septoria/ biotechnology

1067. Russell, J. A., M. Banaras, and B. H. McCown. 1988. Osmotic microenvironments within tissue culture well plates are an important cause of variability in plant protoplast cultures. In Vitro Cellular and Developmental Biology 24:605-608.

Keywords: osmotic potential/ tissue culture/ evaporation

1068. Russell, J. A., and B. H. McCown. 1986. Culture and regeneration of Populus leaf protoplasts isolated from nonseedling tissue. Plant Science 46:133-142.

Keywords: poplars/ regeneration/ thidiazuron/ tissue culture

1069. Russell, J. A., and B. H. McCown. 1986. Techniques for enhanced release of leaf protoplasts in Populus. Plant Cell Reports 5:284-287.

Keywords: poplars/ tissue culture
1070. Sajdak, R. L., Y. Z. Lai, G. D. Mroz, and M. F. Jurgensen. 1981. Forest biomass for energy: A perspective. pp. 2148. In Biomass as a Nonfossil Fuel Source. D. L. Klass (ed.). Symposium Series No. 144. American Chemical Society, San Diego, California.

Keywords: forests

1071. Salk, M. S., and A. G. Folger. 1987. Characterization of the Southwest United States for the Production of Biomass Energy Crops. ORNL/TM-10203. Oak Ridge National Laboratory, Oak Ridge, Tennessee.

Keywords: Southwest/ biomass crops/ energy crops/ production

1072. Sampson, R. N., L. L. Wright, J. K. Winjum, J. D. Kinsman, J. Benneman, E. Kursten, and J. M. O. Scurlock. 1993. Biomass management and energy. pp. 139159. In Water, Air, and Soil Pollution. J. Wisniewski and R. N. Sampson (eds.). Kluwer Academic Publishers, The Netherlands.

Keywords: biomass crops/ carbon dioxide/ biofuels

1073. Sanderson, M. A. 1992.

Morphological development of switchgrass and kleingrass. Agronomy Journal 84:415419.

Keywords: morphology/ switchgrass/ Panicum virgatum/ feedstocks

1074. Sanderson, M. A. 1997. Describing the morphological development of herbage grasses: A brief review. Developments in Agronomy 1:9-14.

Keywords: morphology

1075. Sanderson, M. A., R. P. Egg, and A. E. Wiselogel. 1997. Biomass losses during harvest and storage of switchgrass. Biomass and Bioenergy 12(2):107-114. Keywords: biomass crops/ harvesting/ switchgrass/ Panicum virgatum/ storage

1076. Sanderson, M. A., M. A. Hussey, W. R. Ocumpaugh, C. R. Tischler, J. C. 
Read, and R. L. Reed. 1995. Evaluation of switchgrass as a sustainable bioenergy crop in Texas. pp. 253-261. In Proceedings of the Second Biomass Conference of the Americas: Energy, Environment, Agriculture, and Industry. National Renewable Energy Laboratory, Golden, Colorado.

Keywords: switchgrass/ Panicum virgatum/ bioenergy/ Texas/ energy crops, herbaceous/ feedstocks/ germplasm

1077. Sanderson, M. A., R. M. Jones, M. J. McFarland, J. Stroup, R. L. Reed, and J. P. Muir. 2001. Nutrient movement and removal in a switchgrass biomass-filter strip system treated with dairy manure. J. Environ. Qual. 30(1):210-216.

Keywords: nutrient cycling/ switchgrass/ Panicum virgatum/ biomass crops/ nutrients, filter strip

1078. Sanderson, M. A., and K. J. Moore. 1999. Switchgrass morphological development predicted from day of the year or degree day models. Agronomy J. 91:732734.

Keywords: switchgrass/ Panicum virgatum/ morphology

1079. Sanderson, M. A., J. C. Read, and R. L. Reed. 1999. Harvest management of switchgrass for biomass feedstock and forage production. Agronomy Journal 91(1):5-10.

Keywords: harvesting/ switchgrass/ Panicum virgatum/ biomass feedstock production

1080. Sanderson, M. A., and R. L. Reed. 2000. Switchgrass growth and development in response to water, nitrogen, and plant density. J. Range Management 53:221-227. Keywords: switchgrass/ Panicum virgatum/ growth/ nitrogen/ plant density

1081. Sanderson, M. A., R. L. Reed, S. B. McLaughlin, S. D. Wullschleger, B. V.

Conger, D. J. Parrish, D. D. Wolf, C. M. Taliaferro, A. A. Hopkins, W. R. Ocumpaugh, M. A. Hussey, J. C. Read, and C. R. Tischler. 1996. Switchgrass as a sustainable bioenergy crop. Bioresource Technology 56:83-93.

Keywords: switchgrass/ Panicum virgatum/ bioenergy/ energy crops, herbaceous

1082. Sanderson, M. A., R. L. Reed, W. R. Ocumpaugh, M. A. Hussey, G. A. Van Esbroeck , J. C. Read, C. R. Tischler, and F. M. Hons. 1999. Switchgrass cultivars and germplasm for biomass feedstock production in Texas. Bioresource Technology 67(3):209-219.

Keywords: switchgrass/germplasm/ feedstocks/ Texas

1083. Sanderson, M. A., and D. D. Wolf. 1995. Morphological development of switchgrass in diverse environments. Agronomy Journal 87(SeptemberOctober):908-914.

Keywords: morphology/ switchgrass/ Panicum virgatum/ feedstocks

1084. Sanderson, M. A., and D. D. Wolf. 1995. Switchgrass biomass composition during morphological development in diverse environments. Crop Science 35(5):1432-1438.

Keywords: morphology/ switchgrass/

Panicum virgatum/ feedstocks

1085. Scarascia-Mugnozza, G. E., R. J. Ceulemans, P. E. Heilman, J. G. Isebrands, R. F. Stettler, and T. M. Hinckley. 1997. Production physiology and morphology of Populus species and their hybrids grown under short rotation. II. Biomass components and harvest index of hybrid and parental species clones.

Canadian Journal of Forest Research 27:285-294.

Keywords: physiology/ morphology/ poplars/ hybrids/ short rotation woody crops/ clonal propagation/ phenology

1086. Scarascia-Mugnozza, G. E., T. M. Hinckley, and R. F. Stettler. 1986.

Evidence for nonstomatal inhibition of net photosynthesis in rapidly dehydrated shoots of Populus. Canadian Journal of Forest 
Research 16:1371-1375.

Keywords: photosynthesis/ stress/ water stress

1087. Scarascia-Mugnozza, G. E., J. G. Isebrands, T. M. Hinckley, and R. F. Stettler. 1989. Dynamics of light interception, leaf area and biomass production in Populus clones in the establishment year. Annales Des Sciences Forestieres 46:515s-518s.

Keywords: crown architecture/ genotypes/ light/ biomass crops/ Populus

1088. Scarascia-Mugnozza, G. E., J. G. Isebrands, T. M. Hinckley, and R. F. Stettler. 1990. Structural characteristics and assimilates translocation patterns of different types of branches in hybrid poplars. In Ecophys: International Workshop, Dynamics of Ecophysiological Processes in Tree Crowns and Forest Canopies. U.S. Forest Service, North Central Forest Experiment Station, Rhinelander, Wisconsin.

Keywords: poplars, hybrid/ structural characteristics/ translocation

1089. Scheithauer, R., and K. Dripchak. 1988. Economics of Vegetable Oil Processing. ORNL/Sub/87-SA185/1. Oak Ridge National Laboratory, Oak Ridge, Tennessee.

Keywords: economics/ oilseeds/ rapeseed

1090. Scheld, H. W., and J. R. Cowles. 1981. Woody biomass potential of the Chinese tallow tree. Economic Botany 35:391-397.

Keywords: Chinese tallow trees/ productivity

1091. Scheld, H. W. , J. R. Cowles, C. R. Engler, R. L. Kleiman, S. L. Mathieu, and E. B. Shultz, Jr. 1984. Seeds of the Chinese tallow tree, Sapium sebiferum (L.)

Roxb., as a source of chemicals and fuel. In

Fuels and Chemicals from Oilseeds:

Technology and Policy Options. R. P. Morgan and E. B. Shultz, Jr. (eds.). Westview Press, Washington, DC.
Keywords: Chinese tallow trees/ composition, chemical/ by-products/ oilseeds

1092. Scheld, H. W. , J. R. Cowles, R. L. Kleiman, C. R. Engler, and E. B. Shultz, Jr. 1983. Sapium sebiferum. pp. 46-49. In Firewood Crops: Shrub and Tree Species for Energy Production. National Academy Press, Washington, DC.

Keywords: Sapium sebiferum

1093. Schiller, A., and V. R. Tolbert. 1996. Hardwood energy crops and wildlife diversity: Investigating potential benefits for breeding birds and small mammals. pp.

851-857. In Bioenergy '96, Partnerships to Develop and Apply Biomass Technologies. Keywords: short-rotation woody crops/ poplars, hybrid/ Populus/ sycamores/ sweetgum/ perennials/ wildlife/ hardwoods/ energy crops

1094. Schipper, Jr., A. L., and M. A. Palmer. 1979. Distribution of Septotinia leaf spot of poplars in the north central United States. Phytopathology 69:1044. Keywords: poplars/ diseases

1095. Schubert, T. H. 1985. Preliminary results of Eucalyptus/legume mixtures in Hawaii. Nitrogen Fixing Tree Research Reports 3:65-66.

Keywords: Eucalyptus/ legumes/ nitrogen fixation/ admixtures

1096. Schubert, T. H., D. S. DeBell, and C. D. Whitesell. 1988. Eucalyptus/legume mixtures for biomass production in Hawaii. Nitrogen Fixing Tree Research Reports 6:26-27.

Keywords: Eucalyptus/ Albizia/ admixtures/ legumes

1097. Schubert, T. H., and G. P. Markin. 1987. Control of ambrosia beetle in Eucalyptus stumps, 1984. Insecticide and Acaricide Tests 12:352-352.

Keywords: Eucalyptus/ pests/ beetles, ambrosia 
1098. Schubert, T. H., R. F. Strand, T. G. Cole, and K. E. McDuffie. 1988.

Equations for Predicting Biomass of Six Introduced Subtropical Tree Species, Island of Hawaii. PSW-401. U.S. Forest Service, Pacific Southwest Forest Experiment Station, Berkeley, California. Keywords: biomass crops/ Albizia falcatarial Eucalyptus grandis/ Acacia melanoxylon/ Eucalyptus globulus/ Eucalyptus robustal Eucalyptus urophyllal prediction equations

1099. Schubert, T. H., and C. D. Whitesell. 1985. Species Trials for Biomass Plantations in Hawaii: A First Appraisal. PSW-176. U.S. Forest Service, Pacific Southwest Forest Experiment Station, Berkeley, California.

Keywords: species selection/ Eucalyptus/ Albizial Acacia/ biomass crops/ Hawaii

1100. Schulte, P. J., and T. M. Hinckley. 1985. A comparison of pressure-volume curve data analysis techniques. Journal of Experimental Botany 36:1590-1602. Keywords: models

1101. Schulte, P. J., and T. M. Hinckley. 1985. Stomatal aperture and guard cell water relationships in Populus. Plant Physiology (Suppl.) 77:142.

Keywords: poplars/ stomata/ guard cells/ water potential

1102. Schulte, P. J., and T. M. Hinckley. 1987. Abscisic acid relations and the response of Populus trichocarpa stomata to leaf water potential. Tree Physiology 3:103113.

Keywords: abscisic acid/ poplars/ stomata/ leaves/ Populus trichocarpa

1103. Schulte, P. J., and T. M. Hinckley. 1987. The relationship between guard cell water potential and the aperture of stomata in Populus. Plant Cell Environment 10:313318.

Keywords: Populus trichocarpa/ poplars/ stomata/ guard cells/ water potential
1104. Schulte, P. J., T. M. Hinckley, and R. F. Stettler. 1987. Stomatal responses of Populus to leaf water potential. Canadian Journal of Botany 65:255-260.

Keywords: poplars/ stomata/ water potential

1105. Schultz, E. B., and S. B. Land, Jr. 1987. Juvenile-mature correlations in sycamore. pp. 376-383. In Proceedings, 19th Southern Forest Improvement Conference. National Technical Information Service, Springfield, Virginia. Keywords: sycamores/ Platanus occidentalis/ selection

1106. Schultz, R. C., J. G. Isebrands, and P. P. Kormanik. 1982. Populus hybrids form VA endomycorrhizae. pp. 38. In Proceedings of the Seventh North American Forest Biology Workshop: Physiology and Genetics of Intensive Culture. University of Kentucky, Lexington, Kentucky.

Keywords: poplars, hybrid/ mycorrhiza

1107. Schutt, J. R., H. H. Shugart, and J. W. Ranney. 1985. Crown Geometry of Plantation-Grown American Sycamore and Its Simulation. ORNL/TM-9721. Oak Ridge National Laboratory, Oak Ridge, Tennessee.

Keywords: sycamores/ crown architecture

1108. Schwartz, P. M., S. P. Timmins, D. A. Levine, and C. T. Hunsaker. 1995. TERRAIN: A Computer Program to Process Digital Elevation Models for Modeling Surface Flow. ORNL/TM-13071. Oak Ridge National Laboratory, Oak Ridge, Tennessee.

Keywords: models

1109. Scurlock, J. M. O. 1999. Miscanthus: A Review of European Experience with a Novel Energy Crop. ORNL/TM-13732. Oak Ridge National Laboratory, Oak Ridge, Tennessee. Keywords: miscanthus/ energy crops/ grasses/ energy crops, herbaceous

1110. Scurlock, J. M. O. 2000. Bamboo: An Overlooked Biomass Resource? 
ORNL/TM-1999/264. Oak Ridge National Laboratory, Oak Ridge, Tennessee.

Keywords: bamboo/ biomass crops/ grasses/ energy crops, herbaceous

1111. Scurlock, J. M. O., D. C. Dayton, and B. Hames. 2000. Bamboo: An overlooked biomass resource? Biomass \& Bioenergy 19:229-244.

Keywords: bamboo/ fuel properties/ energy crops/ grasses/ energy crops, herbaceous/ bioenergy/ productivity

1112. Seeman, S. S., G. M. Tabor, and H. S. McNabb, Jr. 1999. Conservation of disease resistance gene analogs across plant taxa (abstract). pp. 4-5. In 111th Annual Meeting of the Iowa Academy of Science. Keywords: conservation/ diseases/ genes

1113. Sellmer, J. C., B. H. McCown, and B. E. Haissig. 1989. Shoot culture dynamics of six Populus clones. Tree Physiology 5:219-227.

Keywords: biotechnology/ clonal propagation/ Populus

1114. Shelton, M. G., G. L. Switzer, L. E. Nelson, J. B. Baker, and C. W. Mueller. 1982. The Development of Cottonwood Plantations on Alluvial Soils: Dimensions, Volume, Phytomass, Nutrient Content and Other Characteristics. Technical Bulletin 113. Mississippi State University, Mississippi State, Mississippi.

Keywords: cottonwoods/ soils/ biomass/ nutrients

1115. Sheppard, L. A., A. M. Brunner, K. V. Krutovskii, W. H. Rottmann, J. S. Skinner, S. S. Vollmer, and S. H. Strauss. 2000. A DEFICIENS homolog from the Dioecious Tree Black Cottonwood is expressed in female and male floral meristems of the two-whorled, unisexual flowers. Plant Physiology 124:627-639. Keywords: trees, dioecious/ cottonwoods/ floral meristems/ DEFICIENS

1116. Sibold, K. 1990. Planting for energy. Iowa Conservationist 13-15.
Keywords: economics/ production/ energy crops

1117. Singh, S. K., W. P. Walawender, L. T. Fan, and W. A. Geyer. 1986. Steam gasification of cottonwood (branches) in fluidized bed. Journal of Wood and Fiber Science 18:327-344.

Keywords: cottonwoods/ gasification

1118. Skolmen, R. G. 1986. Performance of Australian Provenances of Eucalyptus grandis and Eucalyptus saligna in Hawaii. PSW-181. U.S. Forest Service, Pacific Southwest Forest Experiment Station, Berkeley, California.

Keywords: Eucalyptus grandis/ Eucalyptus saligna

1119. Skrukrud, C. L., S. E. Taylor, D. R. Hawkins, and M. Calvin. 1986.

Triterpenoid biosynthesis in Euphorbia lathyris. pp. 3. In Plant Lipids:

Biochemistry, Structure, and Function. Plenum Press, New York.

Keywords: triterpenoids/ biosynthesis/ Euphorbia lathyris/ latex

1120. Sladden, S. E., and D. I. Bransby. 1989. Improved Conversion of Herbaceous Biomass to Biofuels: Potential for Modification of Key Plant Characteristics, Final Report on a Literature Review and Survey. ORNL/Sub/88-SC011/1. Oak Ridge National Laboratory, Oak Ridge, Tennessee.

Keywords: conversion technologies/ energy crops, herbaceous/ biomass crops/ biofuels

1121. Sladden, S. E., and D. I. Bransby. 1995. Responses of Alabama farmers to a survey on growing switchgrass for energy. pp. 1309-1313. In Proceedings of the Second Biomass Conference of the Americas. National Renewable Energy Laboratory, Golden, Colorado.

Keywords: switchgrass/ Panicum virgatum/ yields/ Alabama/ biomass crops/ farmers

1122. Sladden, S. E., D. I. Bransby, and G. E. Aiken. 1991. Biomass yield, 
composition and production costs for eight switchgrass varieties in Alabama. Biomass and Bioenergy 1(2):119-122.

Keywords: energy crops, herbaceous/ Panicum virgatum/ yields/ composition, chemical/ production/ Alabama

1123. Sladden, S. E., D. I. Bransby, and G. E. Aiken. 1991. High productivity of switchgrass creates enthusiasm in AAES research. Highlights of Agricultural Research 38:4.

Keywords: switchgrass/ Panicum virgatum/ perennials/ yields

1124. Sladden, S. E., D. I. Bransby, G. E. Aiken, and G. M. Prine. 1991. Biomass yield and composition and winter survival of tall grasses in Alabama. Biomass and Bioenergy 1(2):123-127.

Keywords: yields/ composition, chemical/ napiergrass/ energy cane/ sorghum/ sugarcane/ Pennisetum/ Acer/ cold hardiness

1125. Sladden, S. E., D. I. Bransby, D. D. Kee, and P. Nepal. 1995. The effects of row spacing and nitrogen fertilization on biomass production of switchgrass in Alabama. pp. 45-48. In Proceedings of the American Forest and Grassland Council. Keywords: fertilization/ biomass crops/ switchgrass/ Panicum virgatum/ Alabama/ biofuels/ stand density

1126. Smith, J. A., M. E. Ostry, N. A. Anderson, and R. A. Blanchette. 2000. Etiology of bronze leaf disease of Populus (abstract). Phytopathology 90:S73.

Keywords: etiology/ disease, bronze leaf/ Populus

1127. Smith, V. A., D. B. Orr, and E. R. Hart. 1993. Economic analysis of twospotted spider mite management on greenhouse-grown poplars. Tree Planters' Notes 154-156.

Keywords: economics/ spider mites/ greenhouse/ poplars

1128. Smith, W. H., and M. L. Dowd. 1981. Biomass production in Florida.
Journal of Forestry 79:508-511, 515. Keywords: Florida/ biomass crops

1129. Snook, S. K., P. Labosky, Jr., T. W. Bowersox, and P. R. Blankenhorn. 1985. Pulp and papermaking properties of hybrid poplar grown under four management strategies and two soil sites. Wood and Fiber Science 18:157-167.

Keywords: poplars/ crop management/ paper/ pulpwood

1130. Sokhansanj, S., A. F. Turhollow, K. Kadam, and J. McMillan. 2001. Stalking a new fuel source. Resource 8(5):11-12.

Keywords: corn/ ethanol/ fuels/ corn stover/ conversion technologies

1131. Somleva, M. N., Z. Tomaszewski, and B. V. Conger. 2002. Agrobacteriummediated genetic transformation of switchgrass. Crop Science 42:2080-2087. Keywords: switchgrass/ transformation/ agrobacterium/genetics/ herbicides

1132. Sommer, H. E. 1982. Literature guide for plant tissue culture. pp. 599-607. In CRC Handbook of Biosolar Resources. O. R. Zaborsky, A. Mitsui, and C. C. Black (eds.). CRC Press, Inc., Boca Raton, Florida.

Keywords: tissue culture/ callus/ breeding

1133. Sommer, H. E. 1982. Sources and collections of woody forest plants. pp. 597598. In CRC Handbook of Biosolar Resources. O. R. Zaborsky, A. Mitsui, and C. C. Black (eds.). CRC Press, Inc., Boca Raton, Florida.

Keywords: seedlings/ woody crops

1134. Sommer, H. E. 1983.

Organogenesis in woody angiosperms: Applications to vegetative propagation. Bulletin De La Societe Botanique De France 130:79-85.

Keywords: propagation/ poplars/ sweetgum/ Liquidambar styraciflua/ clonal propagation 
1135. Sommer, H. E., and C. L. Brown. 1979. Application of tissue culture to forest tree improvement. pp. 461-491. In Plant Cell and Tissue Culture Principles and Applications. W. R. Sharp, P. O. Larsen, E. F. Paddock, and V. Raghavan (eds.). Ohio State University Press, Columbus, Ohio. Keywords: tissue culture/ tree improvement

1136. Sommer, H. E., and C. L. Brown. 1980. Embryogenesis in tissue culture of sweetgum. Forest Science 26:257-260. Keywords: Liquidambar styraciflua/ clonal propagation/ tissue culture/ embryogenesis

1137. Sommer, H. E., and L. S. Caldas. 1981. In vitro methods applied to forest trees. pp. 349-358. In Plant Tissue Culture. T. A. Thorpe (ed.). Academic Press, Inc., New York.

Keywords: tissue culture/ propagation/ tree improvement

1138. Sommer, H. E., and H. Y. Wetzstein. 1984. Hardwoods. pp. 511540. In Handbook of Plant Cell Culture. D. A. Evans, W. R. Sharp, P. V Ammirato, and Y. Yomado (eds.). MacMillan Company, New York.

Keywords: hardwoods/ tissue culture

1139. Sommer, H. E. , H. Y. Wetzstein, and N. Lee. 1985. Advances in the tissue culture of Liquidambar styraciflua L. In Proceedings, Eighteenth Southern Forest Tree Improvement Conference. U.S. Forest Service, Southern Forest Experiment Station, Gulfport, Mississippi.

Keywords: Liquidambar styraciflua/ tissue culture

1140. Sommer, H. E. , H. Y. Wetzstein, M. Stine, and N. Lee. 1984.

Differentiation in tissue culture of sweetgum and southern pines. pp. 35-37. In

Proceedings, 1984 TAPPI Research and Development Conference. TAPPI Press, Atlanta, Georgia.

Keywords: Liquidambar styraciflual Pinus palustris/ Pinus elliottii/ clonal propagation
1141. Son, S. H., H. K. Moon, and R. B.

Hall. 1993. Somaclonal variation in plants regenerated from callus culture of hybrid aspen (Populus alba L. $\times$ P. grandidentata Michx.). Plant Science 90:89-94.

Keywords: poplars/ tissue culture/ callus/ phenotype/ chromosomes

1142. Son, S. H., Y. G. Park, Y. W. Chun, and R. B. Hall. 1997. Micropropagation, Genetic Engineering, and Molecular Biology of Populus. RM-GTR-297. US Forest Service, Fort Collins, Colorado. Keywords: germplasm/ Populus/ in vitro culture/ biodiversity

1143. Sopper, W. E. , D. R. DeWalle, and S. N. Kerr. 1979. Utilization of municipal wastewater and waste heat for energy production from forest biomass. pp. 572581. In Proceedings, Third National Conference on Technology for Energy Conservation. Information Transfer, Inc., Silver Springs, Maryland.

Keywords: wastewater/ waste heat/ energy/ forests

1144. Sopper, W. E., and S. N. Kerr. 1979. Increased woody biomass production and land treatment of wastewater: An economic symbiotic relationship. pp. 118125. In Proceedings, Technology for Energy Conservation. Information Transfer, Inc., Silver Springs, Maryland.

Keywords: short rotation woody crops/ production/ land/ wastewater/ economics

1145. Sopper, W. E., and S. N. Kerr. 1979. Maximizing forest biomass energy production by municipal wastewater irrigation. pp. 115-133. In Proceedings, Energy from Biomass and Wastes III. Institute of Gas Technology, Chicago, Illinois.

Keywords: forests/ biomass crops/ energy/ wastewater/ irrigation/ poplars, hybrid

1146. Stadt, T. J., and J. W. Hanover. 1983. Recommended Tree Seed Sources for Use in Michigan. Research Report 445. Michigan State University, Agricultural 
Experiment Station, East Lansing, Michigan.

Keywords: Michigan/ species selection/ seed

1147. Steinbeck, K. 1978. Intensively managed short rotation coppice forests. pp. 123-129. In 27th Annual Forestry Symposium: Energy and the Southern Forest. E. T. Choong and J. L. Chambers (eds.). Louisiana State University, School of Forestry and Wildlife Management, Baton Rouge, Louisiana.

Keywords: intensive culture/ short rotation woody crops/ coppice/ silviculture

1148. Steinbeck, K. 1978. Short-rotation hardwood forestry in the Southeast. pp. 175-183. In 2nd Annual Symposium on Fuels from Biomass. Rensselaer Polytechnic Institute, Troy, New York. Keywords: short rotation woody crops/ hardwoods/ Southeast

1149. Steinbeck, K. 1980. Biomass energy sources for Alabama. Journal of the Alabama Academy of Science 51:86-91. Keywords: biomass crops/ Alabama/ biomass resources

1150. Steinbeck, K. 1981. Energy output/input ratios for short-rotation growth of American sycamore. pp. 71-77. In Fuels from Biomass and Wastes. D. L. Klass and G. H. Emert (eds.). Ann Arbor Science Publishers, Ann Arbor, Michigan. Keywords: sycamores/ fuels/ biomass crops/ wastes/ short rotation woody crops/ growth/ wood

1151. Steinbeck, K. 1981. Short-rotation forestry as a biomass source: An overview. pp. 163-171. In Proceedings, Energy from Biomass, 1st European Communities Conference. Applied Science Publishers Ltd., London.

Keywords: short rotation woody crops/ biomass crops

1152. Steinbeck, K. 1983. Potentialities of short-rotation forestry for developing countries. Outlook Agriculture 12:160-164. Keywords: short rotation woody crops/ economics

1153. Steinbeck, K., and L. C. Nwoboshi. 1980. Rootstock mass of coppiced Platanus occidentalis as affected by spacing and rotation length. Forest Science 26:545-547. Keywords: sycamores/ coppice/ rootstock/ rotation length/ stand density

1154. Stettler, R. F., and H. D. Bradshaw, Jr. 1994. The choice of genetic material for mechanistic studies of adaptation in forest trees. pp. 781-796. In Tree Physiology.

Keywords: genetics/ mechanistic studies/ forests

1155. Stettler, R. F., H. D. Bradshaw, Jr., and L. Zsuffa. 1992. The role of genetic improvement in short rotation forestry. pp. 285-308. In Ecophysiology of Short Rotation Forest Crops. C. P. Mitchell, J. B. Ford-Robertson, T. M. Hinckley, and L. Sennerby-Forsse (eds.). Elsevier Science Publishers Ltd., New York.

Keywords: genetic modification/ short rotation woody crops/ silviculture

1156. Stettler, R. F., and R. J.

Ceulemans. 1993. Clonal material as a focus for genetic and physiological research in forest trees. pp. 68-86. In Clonal Forestry I, Genetics and Biotechnology, Chapter 6. M. R. Ahuja and W. J. Libby (eds.). Springer-Verlag, New York. Keywords: clonal propagation/genetics/ physiology/ forests/ phenology/ shoots/ roots

1157. Stettler, R. F., R. C. Fenn, and A. L. Figliola. 1982. Genetic and physiological studies of Populus trichocarpa and its hybrids. In Proceedings, 7th North American Forest Biology Workshop. University of Kentucky, Lexington, Kentucky.

Keywords: Populus trichocarpa/ genetic modification/ physiology 
1158. Stettler, R. F., R. C. Fenn, P. E. Heilman, and B. J. Stanton. 1988.

Populus trichocarpa $\times$ Populus deltoides hybrids for short rotation culture: Variation patterns and 4-year field performance. Canadian Journal of Forest Research 18:745-753.

Keywords: short rotation woody crops/ poplars/ Populus trichocarpal Populus deltoides

1159. Stettler, R. F., and P. E. Heilman. 1980. Evaluation and genetic improvement of black cottonwood (Populus trichocarpa) for short-rotation coppice culture. pp. 574575. In Proceedings, BioEnergy-80. The Bio-Energy Council, Washington, DC. Keywords: genetic modification/ cottonwoods/ poplars/ short rotation woody crops/ coppice

1160. Stettler, R. F., and P. E. Heilman. 1984. Short-rotation poplar culture in the Pacific Northwest: Components of a genetic program. pp. 217-232. In Ecology and Management of Forest Biomass Production Systems. K. Perttu (ed.). Agricultural Science Report 15. Swedish University of Agricultural Science, Uppsala, Sweden. Keywords: biomass crops/ climate/ Populus deltoides/ Populus trichocarpa

1161. Stettler, R. F., T. M. Hinckley, H. D. Bradshaw, Jr., and P. E. Heilman. 1993. Genetic Improvement and Evaluation of Black Cottonwood for Short-rotation Biomass Production - Final Report. ORNL/Sub/83-43382/8. Oak Ridge National Laboratory, Oak Ridge, Tennessee. Keywords: genetic modification/ cottonwoods/ short rotation woody crops

1162. Stettler, R. F., R. Koster, and V. Steenackers. 1980. Interspecific crossability studies in poplars. Theoretical and Applied Genetics 58:273-282.

Keywords: poplars/ genomic manipulation

1163. Stettler, R. F., L. Zsuffa, and R. Wu. 1996. The role of hybridization in the genetic manipulation of Populus. pp.
87-112. In Biology of Populus and its Implications for Management and Conservation. R. F. Stettler, Jr., H. D. Bradshaw, P. E. Heilman, and T. M. Hinckley (eds.). NRC Research Press, Ottawa, Canada.

Keywords: hybridization/genetic modification/ Populus/ poplars/ hybrids

1164. Stimely, G. L., and P. R. Blankenhorn. 1985. Effects of species, specimen size, and heating rate on char yield and fuel properties. Wood and Fiber Science 17:477-489.

Keywords: energy content/ species selection/ fuel properties/ heating values

1165. Stokes, B. J. (ed.). 1997. Proceedings of the First Conference of the Short-Rotation Woody Crops Operations Working Group. Auburn University, Auburn, Alabama.

Keywords: short-rotation woody crops/ forests/ poplars, hybrid/ harvesting

1166. Stokes, B. J., D. J. Frederick, and D. T. Curtin. 1986. Field trials of a shortrotation biomass feller buncher and selected harvesting systems. Biomass 11:185-204.

Keywords: biomass crops/ yields/ production/ harvesting/ short rotation woody crops

1167. Strand, R. F., and C. D. Whitesell. 1989. Managing Eucalyptus plantations for maximum yield. pp. 89-98. In Proceedings of the Third Pacific Basin Biofuels Workshop. University of Hawaii, Hawaii Natural Energy Institute, Waianae, Oahu, Hawaii.

Keywords: crop management/ Eucalyptus/ short rotation intensive culture/ fertility/ biomass crops/ soil properties

1168. Strauss, C. H., P. R. Blankenhorn, T. W. Bowersox, and S. C. Grado. 1984. Net financial and energy analyses for producing Populus hybrid under four management strategies. pp. 251-272. In Proceedings, Energy from Biomass and Wastes VIII. D. L. Klass (ed.). Institute of 
Gas Technology, Chicago, Illinois.

Keywords: economics/ input-output analysis/ Populus/ crop management

1169. Strauss, C. H., P. R. Blankenhorn, T. W. Bowersox, and S. C. Grado. 1986. Cost analysis of alternate biomass supply systems. pp. 193-199. In 21st Intersociety Energy Conversion Engineering Conference. American Chemical Society, San Diego, California.

Keywords: economics/ resource assessment/ biomass resources

1170. Strauss, C. H., P. R. Blankenhorn, T. W. Bowersox, and S. C. Grado. 1987. Production costs for first rotation biomass plantations. Biomass 12:215-226.

Keywords: poplars/ economics/ short rotation woody crops/ economics

1171. Strauss, C. H., P. R. Blankenhorn, T. W. Bowersox, and S. C. Grado. 1988. A cost analysis of alternate biomass supply systems. Forest Products Journal 38:47-51. Keywords: economics/ resource assessment/ biomass resources

1172. Strauss, C. H., P. R. Blankenhorn, T. W. Bowersox, and S. C. Grado. 1988. Financial and energy costs of supplying biomass to conversion sites. Applied Biochemistry and Biotechnology 17:31-44. Keywords: economics/ resource assessment/ biomass resources/ input-output analysis

1173. Strauss, C. H., S. C. Grado, P. R. Blankenhorn, and T. W. Bowersox. 1988. Second rotation cost evaluations of biomass from short rotation intensive culture Populus plantations. pp. 66-84. In Proceedings, Energy from Biomass and Wastes XII. D. L. Klass (ed.). Institute of Gas Technology, Chicago, Illinois.

Keywords: economics/ Populus/ crop management/ economics

1174. Strauss, C. H., S. C. Grado, P. R. Blankenhorn, and T. W. Bowersox. 1989. Developing financial and energy accounting models for woody biomass systems. Solar Energy 42:379-386.

Keywords: poplars/ economics/ inputoutput analysis

1175. Strauss, C. H., S. C. Grado, P. R. Blankenhorn, and T. W. Bowersox. 1990. Cost parameters affecting multiple rotation SRIC biomass systems. Applied

Biochemistry and Biotechnology 24-25:721733.

Keywords: economics/ short rotation woody crops/ harvesting/ storage/ poplars

1176. Strauss, C. H., S. C. Grado, P. R. Blankenhorn, and T. W. Bowersox. 1990. Economic evaluations of optimum rotation age for SRIC plantations. pp. 295-308. In Proceedings, Energy from Biomass and Wastes XIII. D. L. Klass (ed.). Institute of Gas Technology, Chicago, Illinois.

Keywords: poplars, hybrid/ models/ economics/ crop management

1177. Strauss, C. H., and L. L. Wright. 1991. Woody biomass production costs in the United States: An economic summary of commercial Populus plantation systems. pp. 359-369. In Proceedings, Energy from Biomass and Wastes XIV. D. L. Klass (ed.). Institute of Gas Technology, Chicago, Illinois.

Keywords: poplars/ economics

1178. Strauss, S. H., S. P. DiFazio, and R. Meilan. 2001. Genetically modified poplars in context. The Forestry Chronicle 77(2):271-279.

Keywords: biotechnology/ environmental risk assessment/ forestry/ genetic modification/ Populus

1179. Strauss, S. H., S. A. Knowe, and J. Jenkins. 1997. Benefits and risks of transgenic, roundup ready cottonwoods. Journal of Forestry 95(5):12-19.

Keywords: transgenic/ poplars, hybrid/ Populus/greenhouse/ genetics/ herbicides

1180. Strauss, S. H., and R. Meilan. 2000. Tree Genetic Engineering Research 
Cooperative. Western Forester 45(2): 14. Keywords: Populus

1181. Strauss, S. H., K. Raffa, and P. List. 2000. Ethics and transgenic plantations. Journal of Forestry 98(7):4748.

Keywords: transgenic/ Populus/ ethics

1182. Strauss, S. H., W. H. Rottmann, A. M. Brunner, and L. A. Sheppard. 1995. Genetic engineering of reproductive sterility in forest trees. Molecular Breeding 1:5-26.

Keywords: flowering/ Populus/ conifers/ genetic modification/ reproduction/ genetics

1183. Strickland, R. 1995. Cleaner fuel from cash crop. American Agriculturist 6 . Keywords: fuels/ willows/ wood biomass

1184. Strong, T. F. 1980. Energy Values of Nine Populus Clones. NC-257. U.S. Forest Service, North Central Forest Experiment Station, Duluth, Minnesota. Keywords: Populus/ energy content

1185. Strong, T. F. 1989. Rotation Length and Repeated Harvesting Influence Populus Coppice Production. NC-350. U.S. Forest Service, North Central Forest Experiment Station, Duluth, Minnesota.

Keywords: biomass crops/ short rotation woody crops/ mortality/ sprouting/ stump height

1186. Strong, T. F., and E. A. Hansen. 1991. Response of Three Populus Species to Drought. NC-302. U.S. Forest Service, North Central Forest Experiment Station, St. Paul, Minnesota.

Keywords: growth/ irrigation/ clonal propagation/ drought/ Populus

1187. Strong, T. F., and E. A. Hansen. 1993. Hybrid poplar spacing/productivity relations in short rotation intensive culture plantations. Biomass and Bioenergy 4:255261.

Keywords: biomass crops/ poplars/ clonal propagation/ irrigation/ diseases/ yields
1188. Strong, T. F., and J. Zavitkovski. 1982. Harvesting season affects regeneration and growth of Populus 'Tristis \#1' coppice. pp. 94-102. In Proceedings, 1982 North American Poplar Council Meeting. J. Zavitkovski and E. A. Hansen (eds.). Kansas State University, Manhattan, Kansas.

Keywords: poplars/ harvesting

1189. Stuart, W. B. 1980. Application of computer simulation in evaluating harvesting systems. AIChE Symposium Series 76:31-35.

Keywords: harvesting simulation

1190. Stuart, W. B. 1981. Can we harvest the resource? pp. 117-121. In Proceedings, Ninth Annual Hardwood Symposium of the Hardwood Research Council. Hardwood Research Council, Asheville, North Carolina.

Keywords: hardwoods/ harvesting

1191. Stuart, W. B. 1981. Harvesting analysis technique: A computer simulation system for timber harvesting. Forest Products Journal 31: 45-53.

Keywords: harvesting simulation

1192. Stuart, W. B., and R. G. Oderwald. 1981. Present and future capital investment in timber harvesting. Journal of Forestry 79:748-749.

Keywords: harvesting/ economics/ economics

1193. Stuart, W. B., R. G. Oderwald, and E. C. Ford III. 1980. Prism cruising coefficients for Appalachian hardwoods biomass. Southern Journal of Applied Forestry 4:25-26.

Keywords: hardwoods/ biomass resources

1194. Stuart, W. B., J. V. Perumpral, T. A. Walbridge, Jr., and S. Shartle. 1981. Pine plantation data for future equipment design. Transactions of the ASAE 24 :568-571, 578.

Keywords: crop management/ pines 
1195. Stuart, W. B., C. D. Porter, T. A. Walbridge, Jr., and R. G. Oderwald. 1980. The potential of modifying conventional harvesting systems for recovering logging residues as an energy source. pp. 377-389. In Proceedings, 1980 TAPPI Annual Meeting. TAPPI Press, Atlanta, Georgia.

Keywords: residues/ harvesting

1196. Stuart, W. B., C. D. Porter, T. A. Walbridge, Jr., and R. G. Oderwald. 1981. Economics of modifying harvesting systems to recover energy wood. Forest Products Journal 31:37-42.

Keywords: harvesting/ economics

1197. Stubblefield, G. W. 1983.

Geographic patterns of variation among sweetgum populations in the southern United States. pp. 234-243. In Proceedings, 17th Southern Forest Tree Improvement Conference. University of Georgia, Athens, Georgia.

Keywords: sweetgum/ genetic diversity

1198. Suplick, M. R., J. C. Read, J. P. Johnson, W. R. Ocumpaugh, and M. A. Hussey. 1999. Response of switchgrass to nitrogen fertilizer and harvest dates. pp. 144. In Agronomy Abstracts.

Keywords: switchgrass/ Panicum virgatum/ fertilization/ harvesting

1199. Suplick, M. R., J. C. Read, and D. D. Kee. 1999. Effect of nitrogen on leaf appearance and lamina extension rates in switchgrass. pp. 3. In Abstracts of the 1999 Annual Meeting of the Southern Branch of ASA.

Keywords: switchgrass/ Panicum virgatum/ nitrogen/ leaves

1200. Surles, S. E. , J. Arnold, A. Schnable, J. L. Hamrick, and B. C. Bongarten. 1990. Genetic relatedness in open-pollinated families of two leguminous tree species, Robinia pseudoacacia L. and Gleditsia triacanthos L. Theoretical and Applied Genetics 80:49-56.
Keywords: allozymes/ heritability/ locusts, black/ honeylocusts

1201. Surles, S. E., J. L. Hamrick, and B. C. Bongarten. 1989. Allozyme variation in black locust (Robinia pseudoacacia). Canadian Journal of Forest Research 19:471-479.

Keywords: locusts, black/ allozymes

1202. Surles, S. E., J. L. Hamrick, and

B. C. Bongarten. 1990. Mating systems in open-pollinated families of black locust (Robinia pseudoacacia). Silvae Genetica 39:35-40.

Keywords: short rotation woody crops/ isozymes/ outcrossing rates/ fixation indices

1203. Surles, S. E. , J. L. Hamrick, and B. C. Bongarten. 1990. Mating systems in wild-pollinated families of black locust (Robinia pseudoacacia). Silvae Genetica 39:35-40.

Keywords: short rotation woody crops/ locusts, black/ Robinia pseudoacacial breeding/ genetics

1204. Tabone, T. J. , P. Felker, R. L. Bingham, I. Reyes, and S. Loughrey. 1986. Techniques in the shoot multiplication of the leguminous tree Prosopis alba clone B2V50. Forest Ecology and Management 16:191-200. Keywords: shoots/ Prosopis albal leguminous trees/mesquite

1205. Tabor, G. M., T. L. Kubisiak, N. B. Klopfenstein, R. B. Hall, and H. S. McNabb, Jr. 2000. Bulked segregant analysis identifies molecular markers linked to Melampsora medusae resistance in Populus deltoides. Phytopathology 90(9):1039-1042.

Keywords: segregant analysis/ molecular genetics/ Melampsora medusael Populus deltoides/ diseases/ rusts

1206. Taliaferro, C. M. 2000. Breeding seed- and vegetatively-propagated bermudagrasses and switchgrass. pp. 176. 
In Agronomy Abstracts. American Society of Agronomy, Minneapolis, Minnesota.

Keywords: switchgrass/ Panicum virgatum/ heritability

1207. Taliaferro, C. M. 2002. Breeding and Selection of New Switchgrass Varieties for Increased Biomass Production. ORNL/SUB-02-19XSY162C/01. Oak Ridge National Laboratory, Oak Ridge, Tennessee.

Keywords: switchgrass/ genetics/ breeding/ heritability

1208. Taliaferro, C. M., and A. A. Hopkins. 1996. Breeding characteristics and improvement potential of switchgrass. pp. 2-9. In Liquid Fuel and Industrial Products from Renewable Resources. J. S. Cundiff, E. E. Gavett, C. Hansen, C. Peterson, M. A. Sanderson, H. Shapouri, and D. L. VanDyne (eds.). The American Society of Agricultural Engineers, St. Joseph, Michigan.

Keywords: genetic modification/ growth/ yields/ switchgrass/ Panicum virgatum/ breeding

1209. Taliaferro, C. M., K. P. Vogel, J. H. Bouton, S. B. McLaughlin, and G. A. Tuskan. 1999. Reproductive characteristics and breeding improvement potential of switchgrass. pp. 147-153. In Proceedings of the 4th Biomass Conference of the Americas: Biomass, A Growth Opportunity in Green Energy and ValueAdded Products. R. P. Overend and E. Chornet (eds.). Elsevier Science, Ltd, Oxford, United Kingdom.

Keywords: genetics/ breeding/ switchgrass/ Panicum virgatum

1210. Tang, Z., and S. B. Land, Jr. 1996. Early growth, leaf development, and dryweight production of sycamore rooted cuttings. Biomass and Bioenergy 10(4):221229.

Keywords: growth/ clonal variations/ plantations/ Platanus occidentalis/ clonal propagation/ roots
1211. Tarrant, R. F., B. T. Bormann, D. S. DeBell, and W. A. Atkinson. 1983. Managing red alder in the Douglas-fir region: A look at some possibilities. Journal of Forestry 81:787-792.

Keywords: alders/ crop management

1212. Taylor, S. E., and M. Calvin. 1986. Hydrocarbons from Plants: Biosynthesis and Utilization. LBL-22294. Lawrence Berkeley Laboratory, Berkeley, California. Keywords: hydrocarbons/ isoprenoid biosynthesis/ alkane biosynthesis

1213. Taylor, S. E. , C. L. Skrukrud, and M. Calvin. 1987. The effect of salinity on the allocation of carbon to energy-rich compounds in Euphorbia lathyris. pp. 903916. In Energy from Biomass and Wastes XI, Proceedings, 11th IGT Symposium. Institute of Gas Technology, Chicago, Illinois.

Keywords: Euphorbia lathyris/ salinity

1214. Tharakan, P. J., L. P. Abrahamson, J. G. Isebrands, and D. J. Robison. 1998. First year growth and development of willow and poplar bioenergy crops as related to foliar characteristics. pp. 1170-1180. In Bioenergy '98. Great Lakes Regional Biomass Energy Program, Chicago, Illinois. Keywords: growth/ willows/ poplars/ biomass crops/ clones/ ecophysiology/ specific leaf weight/ productivity

1215. Tharakan, P. J., L. P. Abrahamson, D. J. Robison, J. G. Isebrands, C. A. Nowak, T. A. Volk, and E. H. White. 2000. Coppice effects on willow and hybrid poplar stem attributes and biomass production. pp. 175. In Proceedings of the 21st Session of the International Poplar Commission Meeting, Poplar and Willow Culture: Meeting the Needs of Society and the Environment. J. G. Isebrands and J. Richardson (eds.). NC 215. North Central Research Station, St. Paul, Minnesota. Keywords: willows/ poplars, hybrid/ biomass crops 
1216. Tharakan, P. J., C. A Nowak, and L. P. Abrahamson. 2000. Modeling Growth and Biomass Production in Willow Plantations in the Northeastern and MidAtlantic United States. In Bioenergy 2000: Moving Technology to the Marketplace. Keywords: willows

1217. Tharakan, P. J., C. A. Nowak, L. P. Abrahamson, D. J. Robison, and T. A. Volk. 1999. Characterization of willow bioenergy clones: A step towards improving yield. pp. 26. In Fourth Biomass Conference of the Americas: Biomass: A Growth Opportunity in Green Energy and Value-Added Products.

Keywords: willows/ bioenergy

1218. Tharakan, P. J., D. J. Robison, L. P. Abrahamson, and C. A. Nowak. 2001. Multivariate approach for integrated evaluation of clonal biomass production potential. Biomass and Bioenergy 21:237247.

Keywords: willows/ poplars, hybrid/ short rotation intensive culture/ coppice/ energy crops/genetic selection/ ideotype/ cluster analysis/ New York

1219. Theseira, G. W., G. E. Host, and J. G. Isebrands. 1995. A dynamic threedimensional root growth model for ecophys, an individual tree growth process model for poplar. pp. 21. In Booklet of Abstracts: Dynamics of Physiological Processes in Woody Roots. M. A. Topa, P. T. Rygiewicz, and J. R. Cumming (eds.). Boyce Thompson Institute for Plant Research, Ithaca, New York.

Keywords: roots/ growth/ models, ECOPHYS/ poplars

1220. Theseira, G. W., G. E. Host, J. G. Isebrands, and M. D. Coleman. 1994. Root and soil modeling strategies for ECOPHYS, an individual tree model for juvenile poplar. pp. 1. In The Plant Root Environment. Mississippi State University, Mississippi State, Mississippi. Keywords: roots/ soils/ models/ poplars/ models, ECOPHYS
1221. Thomas, D. L. , M. A. Breve, and P. L. Raymer. 1991. Influence of timing and method of harvest on rapeseed yield. Journal of Production Agriculture 4:266272.

Keywords: rapeseed/ Brassica napus/ harvesting/ yields

1222. Thomas, D. L., M. A. Breve, P. L. Raymer, N. A. Minton, and D. R. Sumner. 1990. Improving Rapeseed Production Practices in the Southeastern United States. ORNL/Sub/86-91324/1. Oak Ridge National Laboratory, Oak Ridge, Tennessee. Keywords: rapeseed/ Brassica napus/ production/ establishment/ harvesting/ yields

1223. Thomas, D. L., F. J. K. DaSilva, and W. A. Cromer. 1988. Image processing technique for plant canopy cover evaluation. Transactions of the ASAE 31:428-434.

Keywords: models/ leaf area

1224. Thompson, P. B., and S. H. Strauss. 2000. Research ethics for molecular silviculture. pp. 585-611. In Molecular Biology of Woody Plants. S. M. Jain and S. C. Minocha (eds.). Kluwer Academic Publishers, The Netherlands.

Keywords: ethics/ silviculture

1225. Tischler, C. R., H. W. Elbersen, M. A. Hussey, W. R. Ocumpaugh, and M. A. Sanderson. 2001. Registration of TEM-LC and TEM-EC switchgrass germplasm. Crop Science 41:1654-1655. Keywords: switchgrass/ Panicum virgatum/ germplasm

1226. Tischler, C. R., and P. W. Voigt. 1993. Characterization of crown node development in Panicoid grasses. Journal of Range Management 46:436-439.

Keywords: crown node

1227. Tischler, C. R., B. A. Young, and M. A. Sanderson. 1994. Facilitating switchgrass breeding programs by rapid alleviation of seed dormancy. Journal of 
Seed Science 22:19-26.

Keywords: seed dormancy/ breeding

1228. Tolbert, V. R. 1998. Guest editorial. Biomass and Bioenergy 14(4):301-306.

Keywords: biomass crops/ energy crops/ residues/ bioenergy/ feedstocks/ energy crops, herbaceous/ short-rotation woody crops

1229. Tolbert, V. R. 1998. Soil and water quality aspects of biomass feedstock production (abstract). Journal of Soil and Water Conservation 55(2):172.

Keywords: carbon sequestration/ environmental effects/ infiltration/ nutrient cycling/ runoff/ carbon, soil/ soil properties/ water quality

1230. Tolbert, V. R., and M. E. Downing. 1995. Environmental effects of planting biomass crops at larger scales on agricultural lands. pp. 1628-1633. In Second Biomass Conference of the Americas. National Renewable Energy Laboratory, Golden, Colorado.

Keywords: environmental effects/ biomass crops/ scale/ energy crops, herbaceous/ short-rotation woody crops/ short rotation woody crops

1231. Tolbert, V. R., J. M. Hanowski, W. Hoffman, A. Schiller, D. C. Christian, and J. E. Lindberg. 1997. Changes in bird community composition in response to growth changes in short-rotation woody crop plantings. pp. 341-348. In Third Biomass Conference of the Americas: Energy, Environment, Agriculture, and Industry. Elsevier.

Keywords: birds/ diversity/ habitat studies/ woody crops

1232. Tolbert, V. R., J. D. Joslin, F. C. Thornton, B. R. Bock, D. E. Pettry, W. E. Bandaranayake, D. D. Tyler, A. E. Houston, and S. H. Schoenholtz. 1999. Biomass crop production: Benefits for soil quality and carbon sequestration. pp. 127132. In Biomass, A Growth Opportunity in
Green Energy and Value-added Products (Proceedings of the 4th Biomass Conference of the Americas). R. P. Overend and E. Chornet (eds.). Elsevier Science, United Kingdom.

Keywords: biomass crops/ crop production/ soil properties/ carbon sequestration

1233. Tolbert, V. R., J. E. Lindberg, T. H. Green, R. K. Malik, W. E. Bandaranayake, J. D. Joslin, F. C. Thornton, D. D. Tyler, A. E. Houston, D. E. Pettry, S. H. Schoenholtz, B. R. Bock, and C. C. Trettin. 1998. Soil and water quality implications of production of herbaceous and woody energy crops. pp. 195-206. In Proceedings of the International Workshop on Environmental Aspects of Energy Crop Production. M. Woergetter and U. Jorgenson (eds.). BLT Wieselburg, Wieselburg, Austria. Keywords: soils/ energy crops, herbaceous/ woody crops/ energy

1234. Tolbert, V. R., D. A. Mays, A. E. Houston, D. D. Tyler, C. H. Perry, K. E. Brooks, F. C. Thornton, B. R. Bock, J. D. Joslin, C. C. Trettin, and J. G. Isebrands. 2000. Ensuring Environmentally Sustainable Production of Dedicated Biomass Feedstocks. In Proceedings of the Ninth Biennial Bioenergy Conference: Bioenergy 2000, Moving Technology into the Marketplace.

Keywords: environmental effects/ soil properties/ water quality/ carbon sequestration

1235. Tolbert, V. R., and A. Schiller. 1996. Environmental enhancement using short-rotation tree crops: Research results and directions. pp. 217-224. In Bioenergy '96, Partnerships to Develop and Apply Biomass Technologies.

Keywords: environment/ energy crops/ wildlife/ birds/ mammals/ soils/ water quality/ erosion

1236. Tolbert, V. R., F. C. Thornton, J. D. Joslin, B. R. Bock, W. E. Bandaranayake, A. E. Houston, D. D. 
Tyler, D. A. Mayes, T. H. Green, and D. E. Pettry. 2000. Increasing belowground carbon sequestion with conversion of agricultural lands to production of bioenergy crops. New Zealand Journal of Forestry Science 30(1/2):138-149. Keywords: carbon, soil/ environmental effects/ energy crops/ carbon sequestration

1237. Tolbert, V. R., F. C. Thornton, J. D. Joslin, B. R. Bock, W. E. Bandaranayake, D. D. Tyler, D. E. Pettry, T. H. Green, R. Makik, A. E. Houston, S. H. Schoenholtz, M. Shires, L. Bingham, and J. Dewey. 1998. Soil and water quality aspects of herbaceous and woody energy crop production: Lessons from researchscale comparisons with agricultural crops. pp. 1272-1281. In BioEnergy '98,

Proceedings of the 8th Biennial Conference. Great Lakes Regional Biomass Energy Program, Chicago, Illinois.

Keywords: soil properties/ water quality/ erosion/ runoff/ soil stability/ environmental effects

1238. Tolbert, V. R., F. C. Thornton, J. D. Joslin, B. R. Bock, A. E. Houston, D. D. Tyler, T. H. Green, S. H. Schoenholtz, D. E. Pettry, and C. C. Trettin. 1997. Environmental effects of growing short-rotation woody crops on former agricultural lands. pp. 297-301. In Third Biomass Conference of the Americas: Energy, Environment, Agriculture, and Industry. Elsevier.

Keywords: environmental effects/ biomass crops/ erosion/ short-rotation woody crops/ switchgrass/ Panicum virgatum/ nutrient cycling/ soils/ feedstocks/ short rotation woody crops/ Populus/ poplars, hybrid

1239. Tolbert, V. R., D. E. Todd, L. K. Mann, C. M. Jawdy, D. A. Mays, R. K. Malik, W. E. Bandaranayake, A. E. Houston, D. D. Tyler, and D. E. Pettry. 2002. Changes in soil quality and belowground carbon storage with conversion of traditional agricultural crop lands to bioenergy crop production. Environmental Pollution 116:97-106.
Keywords: biomass crops/ soil properties/ carbon, soil

1240. Tolbert, V. R., and L. L. Wright. 1998. Environmental enhancement of U.S. biomass crop technologies: Research results to date. Biomass and Bioenergy 15(1):93100.

Keywords: environmental effects/ biodiversity/ habitat studies/ erosion/ quality/ runoff

1241. Tolsted, D. N. 1988. Liming Soils Above pH 5.2 Does Not Increase Populus Growth. NC-344. U.S. Forest Service, North Central Forest Experiment Station, Duluth, Minnesota.

Keywords: growth/ soil properties/ Populus

1242. Tolsted, D. N., and E. A. Hansen. 1992. Age of Hybrid Poplar Stools at First Cut Influences Third-Year Cutting Production. Research Note NC-357. U.S. Forest Service, North Central Forest Experiment Station, St. Paul, Minnesota. Keywords: cuttings/ poplars, hybrid/ harvesting/ short rotation intensive culture

1243. Torreano, S. J., and D. J.

Frederick. 1988. Influence of site condition, fertilization and spacing on short rotation hardwood coppice and seedling yields. Biomass 16:183-198.

Keywords: biomass crops/ sycamores/ Platanus occidentalis/ site characteristics/ fertility/ coppice

1244. Trimble, J. L., and C. R. Shriner. 1981. Inventory of United States Forest Growth Models. ORNL/Sub-80/13819/1. Oak Ridge National Laboratory, Oak Ridge, Tennessee.

Keywords: growth, forest/ models

1245. Trimble, J. L., R. I. Van Hook, and A. G. Folger. 1985. Biomass for energy: The environmental issues. Biomass 6:3-13. Keywords: environmental effects

1246. Tschaplinski, T. J., and T. J. Blake. 1989. Correlation between early root 
production, carbohydrate metabolism, and subsequent biomass production in hybrid poplar. Canadian Journal of Botany 67:2168-2174.

Keywords: poplars, hybrid/ carbohydrates/ roots/ selection

1247. Tschaplinski, T. J., and T. J. Blake. 1989. Photosynthetic reinvigoration of leaves following shoot decapitation and accelerated growth of coppice shoots. Physiologia Plantarum 75:157-165.

Keywords: photosynthesis/ shoots/ coppice/ diurnal pattern/ water relations/ Populus deltoides/ Populus maximowiczii/ Populus nigra/ rejuventaiton/ senescence

1248. Tschaplinski, T. J., and T. J. Blake. 1989. The role of sink demand in carbon partitioning and photosynthetic reinvigoration following shoot decapitation. Physiologia Plantarum 75:166-173. Keywords: photosynthesis/ carbon

1249. Tschaplinski, T. J., and T. J. Blake. 1989. Water relations, photosynthetic capacity, and root/shoot partitioning of photosynthate as determinants of productivity in hybrid poplar. Canadian Journal of Botany 67:1689-1697.

Keywords: water relations/ photosynthesis/ roots/ shoots/ poplars, hybrid/ Populus deltoides/ Populus nigra

1250. Tschaplinski, T. J., and T. J. Blake. 1989. Water-stress tolerance and lateseason organic solute accumulation in hybrid poplar. Canadian Journal of Botany 67:1681-1688.

Keywords: water stress/ organic solute accumulation/ poplars, hybrid

1251. Tschaplinski, T. J., and T. J. Blake. 1994. Carbohydrate mobilization following defoliation and shoot decapitation in hybrid poplar. Tree Physiology 14:141-151.

Keywords: carbon/ fructose/ galactose/ glucose/ poplars, hybrid/ starch/ sucrose/ defoliation
1252. Tschaplinski, T. J., and T. J. Blake. 1995. Growth and carbohydrate status of coppice shoots of hybrid poplar following shoot pruning. Tree Physiology 15:333-338. Keywords: gas exchange/ Populus/ starch/ coppice/ shoot pruning/ poplars, hybrid

1253. Tschaplinski, T. J., G. M. Gebre, J. E. Dahl, G. T. Roberts, and G. A. Tuskan. 1995. Growth and solute adjustment of calli of Populus clones cultured on nutrient medium containing polyethylene glycol. Canadian Journal of Forest Research 25:1425-1433.

Keywords: callus/ Populus/ clonal propagation/ cottonwoods/ hybrids

1254. Tschaplinski, T. J., D. W. Johnson, R. J. Norby, and D. E. Todd. 1991.

Biomass and soil nitrogen relationships of a one-year-old sycamore plantation. Soil

Science Society of America Journal 55:841847.

Keywords: soil properties/ sycamores/ nitrogen

1255. Tschaplinski, T. J., and R. J.

Norby. 1991. Physiological indicators of nitrogen response in short rotation sycamore plantations. I. $\mathrm{CO}_{2}$ assimilation,

photosynthetic pigments, and soluble carbohydrates. Physiologia Plantarum 82:117-126.

Keywords: carbon dioxide/ carbon/ photosynthesis/ carbohydrates/ sycamores/ fertilization

1256. Tschaplinski, T. J., and R. J.

Norby. 1993. Physiological indicators of nitrogen response in a short rotation sycamore plantation. II. Nitrogen metabolism. Canadian Journal of Botany 71(6):841-847.

Keywords: sycamores/ nitrogen/ nitrogen

1257. Tschaplinski, T. J., D. B. Stewart, P. H. Hansen, and R. J. Norby. 1991. Osmotic adjustment in five tree species under elevated $\mathrm{CO}_{2}$ and water stress. Plant Physiology 96:106. 
Keywords: water stress/ carbon dioxide/ osmotic adjustment

1258. Tschaplinski, T. J., and G. A. Tuskan. 1994. Water-stress tolerance of black and eastern cottonwood clones and four hybrid progeny. II. Metabolites and inorganic ions that constitute osmotic adjustment. Canadian Journal of Forest Research 24:681-687.

Keywords: poplars, hybrid/ water stress/ cottonwoods/ cottonwoods/ Populus trichocarpa/ Populus deltoides/ osmotic adjustment

1259. Tschaplinski, T. J., G. A. Tuskan, G. M. Gebre, and D. E. Todd. 1997.

Biochemical Basis of Drought Tolerance in Hybrid Populus Grown Under Field Production Conditions. C/ORNL93-0236. Oak Ridge National Laboratory, Oak Ridge, Tennessee.

Keywords: drought/ poplars, hybrid/ Populus/ production/ physiology

1260. Tschaplinski, T. J., G. A. Tuskan, G. M. Gebre, and D. E. Todd. 1998. Drought resistance of two hybrid Populus clones grown in a large-scale plantation. Tree Physiology 18:653-658.

Keywords: carbon/ water potential/ osmotic potential/ poplars/ roots/ soil water content

1261. Tschaplinski, T. J., G. A. Tuskan, and C. A. Gunderson. 1994. Water-stress tolerance of black and eastern cottonwood clones and four hybrid progeny. I. Growth, water relations, and gas exchange. Canadian Journal of Forest Research 24:364-371.

Keywords: poplars, hybrid/ water stress/ cottonwoods/ cottonwoods/ Populus trichocarpa/ Populus deltoides/ osmotic adjustment/ gas exchange/ water relations

1262. Turhollow, A. F. 1988. SecondYear Growth and Productivity for Potential Herbaceous Energy Crops in the Southeast and Midwest/Lake States. ORNL/TM10626. Oak Ridge National Laboratory, Oak Ridge, Tennessee.
Keywords: growth/ species selection/ energy crops, herbaceous

1263. Turhollow, A. F. 1991. Screening herbaceous lignocellulosic energy crops in temperate regions of the United States. Bioresource Technology 36:247-252. Keywords: crops, lignocellulosic/ yields/ biomass crops/ species selection

1264. Turhollow, A. F. 1993.

Technologies and the production of energy from biomass. pp. 9-19. In $R C A$ Symposium on Technology Development. University of Tennessee, Knoxville, Tennessee.

Keywords: energy/ biomass crops/ economics/ conversion technologies

1265. Turhollow, A. F. 1994. The economics of energy crop production. Biomass and Bioenergy 6(3):229-241. Keywords: economics/ energy crops/ biomass crops/ energy crops, herbaceous/ short rotation woody crops/ poplars, hybrid/ sorghum/ switchgrass/ Panicum virgatum/ energy cane

1266. Turhollow, A. F. 2000. Costs of Producing Biomass from Riparian Buffer Strips. ORNL/TM-1999/146. Oak Ridge National Laboratory, Oak Ridge, Tennessee. Keywords: biomass crops/ riparian buffer strips

1267. Turhollow, A. F., J. H. Cushman, and J. W. Johnston. 1990. Herbaceous Energy Crops Program: Annual Progress Report for FY 1988. ORNL-6639. Oak Ridge National Laboratory, Oak Ridge, Tennessee.

Keywords: energy crops, herbaceous/ energy crops/ species selection/ oilseeds/ crop management

1268. Turhollow, A. F., M. E. Downing, and J. Butler. 1996. The cost of silage harvest and transport systems for herbaceous crops. pp. 451-458. In Bioenergy '96, Partnerships to Develop and Apply Biomass Technologies. 
Keywords: economics/ energy crops, herbaceous/ biomass crops/ silage/ harvesting/ transportation

1269. Turhollow, A. F., M. E. Downing, and J. Butler. 1998. Forage Harvest and Transport Costs. ORNL/TM-13724. Oak Ridge National Laboratory, Oak Ridge, Tennessee.

Keywords: harvesting/ residues/ economics

1270. Turhollow, A. F., J. W. Johnston, and J. H. Cushman. 1988. Linking energy crop production to conversion: The case of herbaceous lignocellulosic crops to ethanol. RERIC International Energy Journal 10:4149.

Keywords: composition, chemical/ feedstocks/ energy crops, herbaceous/ ethanol/ conversion technologies

1271. Turhollow, A. F., and S. J.

Kanhouwa. 1993. Factors affecting the market penetration of biomass-derived liquid transportation fuels. Applied Biochemistry and Biotechnology 39-40:6170.

Keywords: biomass crops/ ethanol/ regulations/ markets/ fuels/ corn/ energy crops

1272. Turhollow, A. F., and R. D. Perlack. 1991. Emissions of $\mathrm{CO}_{2}$ from energy crop production. Biomass and Bioenergy 1:129-135.

Keywords: carbon dioxide/ greenhouse gases/ poplars/ switchgrass/ Panicum virgatum/ sorghum/ energy crops/ emissions

1273. G. A. Tuskan (ed.). 1992. MarkerAided Selection: A Tool for the Improvement of Forest Tree Species. Canadian Journal of Forest Research 22:999-1061.

Keywords: forests/ morphology/ conifers/ stress/ breeding/ host-pathogen/ spruces/ spruces/ fir/ tomato mosaic virus/ viruses

1274. Tuskan, G. A. 1992. Realized and potential value of genetics and biotechnology for biofuel feedstock improvement. pp. 107-109. In Proceedings of the Annual Automotive Technology Development Contractors Coordination Meeting. Society of Automotive Engineers, Inc., Warrendale, Pennsylvania.

Keywords: genetics/ biotechnology/ biofuels/ feedstocks/ energy crops/ fuels, liquid/ tissue culture/ somaclonal variations/ molecular genetics

1275. Tuskan, G. A. 1997. Clonal forestry, heterosis and advanced-generation breeding. pp. 390-392. In 24th Biennial Southern Forest Tree Improvement Conference. University of Florida. Keywords: forestry/ heterosis/ breeding/ Populus/ propagation

1276. Tuskan, G. A. 1998. Fast-growing short-rotation woody crop systems for phytoremediation of radionuclides. In Proceedings of the Chornobyl Phytoremediation Workshop. PNNL. Keywords: short rotation woody crops/ phytoremediation/ radionuclides

1277. Tuskan, G. A. 1998.

Phytoremediation overview/summary. In Proceedings of the Chornobyl Phytoremediation Workshop. PNNL. Keywords: short rotation woody crops/ phytoremediation/ radionuclides

1278. Tuskan, G. A. 1998. Short-rotation woody crop supply systems in the United States: What do we know and what do we need to know? Biomass and Bioenergy 14(4):307-315.

Keywords: Populus/ silviculture/ breeding/ biotechnology/ mechanization/ sustainability/ environment

1279. Tuskan, G. A. , M. E. Downing, and L. L. Wright. 1994. Current status and future directions for the U.S. Department of Energy's short-rotation woody crop research. pp. 123-132. In Mechanization in Short Rotation, Intensive Culture (SRIC) Forestry. B. J. Stokes and T. P. McDonald (eds.). U.S. Department of Agriculture Forest Service, Auburn, 
Alabama.

Keywords: short rotation woody crops/ Populus

1280. Tuskan, G. A. , K. E. Francis, S. L. Russ, W. H. Romme, and M. G. Turner. 1996. RAPD markers reveal diversity within and among clonal and seedling stands of aspen in Yellowstone National Park, U.S.A. Canadian Journal of Forest Research 26:2088-2098.

Keywords: RAPD markers/ diversity/ seedlings/ aspens

1281. Tuskan, G. A., and T. R. Rensema. 1992. Clonal differences in biomass characteristics, coppice ability, and biomass prediction equations among four Populus clones grown in eastern North Dakota. Canadian Journal of Forest Research 22:348-354.

Keywords: biomass crops/ coppice/ poplars/ North Dakota

1282. Tuskan, G. A., and M. E. Walsh. 2001. Short-rotation woody crop systems, atmospheric carbon dioxide and carbon management: A U.S. case study. The Forestry Chronicle 77(2):259-264.

Keywords: Populus/ biomass crops/ carbon sequestration/ carbon displacement/ Kyoto Protocol/ carbon dioxide

1283. Tuskan, G. A., D. C. West, H. D. Bradshaw, Jr., D. Neale, M. M. Sewell, N. Wheeler, B. Megraw, K. Jech, A. E. Wiselogel, R. Evans, C. Elam, M. Davis, and R. J. Dinus. 1999. Two highthroughput techniques for determining wood properties as part of a molecular genetics analysis of hybrid poplar and loblolly pine. Journal of Applied Biochemistry and Biotechnology 77-79:55-65.

Keywords: wood/ molecular genetics/ poplars/ pines/ feedstocks/ pyrolysis molecular beam mass spectrometry/ markers, genetic/ computer tomography/ quantitative trait loci (QTL)/ lignin/ cellulose/ hemicellulose
1284. Tuskan, G. A. , D. C. West, M. Davis, C. Elam, R. Evans, H. D. Bradshaw, Jr., D. Neale, M. M. Sewell, N. Wheeler, B. Megraw, K. Jech, C. Weirman, and R. J. Dinus. 2001. Development and Validation of MarkerAided Selection Methods for Wood Property Traits in Loblolly Pine and Hybrid Poplar Final Report. ORNL/TM-2001/41. Oak Ridge National Laboratory, Oak Ridge, Tennessee.

Keywords: marker-aided selection/ wood/ pines/ poplars, hybrid

1285. Tuskan, G. A., and L. L. Wright. 1990. Can prairie forestry benefit from biotechnology? pp. 41-44. In Proceedings, 43rd Great Plains Agricultural Council Forestry Committee. GPAC Publ. 132. Colorado State University, Colorado Springs, Colorado. Keywords: biotechnology/ forestry

1286. Tuskan, G. A., and L. L. Wright. 1998. Strategy, results and directions for the genetic improvement of poplars as funded by the U.S. Department of Energy. pp. 1720. In Enhancing the Productivity and Sustainability of Short-Rotation Salicacae. NYCFRD-98-04. SUNY, Syracuse, New York.

Keywords: genetics/ poplars

1287. U.S. Department of Agriculture Forest Service. 1983. Methods of Rapid, Early Selection of Poplar Clones for Maximum Yield Potential: A Manual of Procedures. NC-81. U.S. Forest Service, North Central Forest Experiment Station, Duluth, Minnesota.

Keywords: poplars/ selection

1288. U.S. Department of Agriculture Forest Service, North Central Forest Experiment Station. 1980. Energy and Wood from Intensively Cultured Plantations: Research and Development Program. NC-58. U.S. Forest Service, North Central Forest Experiment Station, Rhinelander, Wisconsin.

Keywords: species selection/ establishment/ 
fiber/ stand density/ harvesting/ crop management/ diseases/ economics

1289. U.S. Department of Agriculture Forest Service, North Central Forest Experiment Station. 1994. Power plants to get power from plants. Agricultural Finance 24-28.

Keywords: biomass crops/ electricity/ conversion technologies

1290. Ugoretz, S. M., K. C. Rineer, and M. E. Downing. 1995. Priorities for ecological research on energy crops in the North Central States. pp. 357-365. In Second Biomass Conference of the Americas. National Renewable Energy Laboratory, Golden, Colorado.

Keywords: ecology/ energy crops/ biomass crops

1291. University of Idaho. 1987. The Potential of Vegetable Oil as an Alternate Source of Liquid Fuel for Agriculture in the Pacific Northwest - V. Miscellaneous Series No. 100. University of Idaho, Colleges of Agriculture and Engineering, Moscow, Idaho.

Keywords: oils, vegetable/ fuels, liquid/ Pacific Northwest

1292. University of Kansas. 1980. The University of Kansas Energy Forest. Document No. 1061-0050. Kansas State University, Department of Forestry, Manhattan, Kansas.

Keywords: fuelwood/ conversion technologies

1293. Van Epps, G., J. R. Barker, and C. M. McKell. 1982. Energy biomass from high producing rangeland shrubs of the intermountain United States. Journal of Range Management 35:22-25.

Keywords: shrubs/ rangeland

1294. Van Esbroeck, G. A., M. A. Hussey, and M. A. Sanderson. 1997. Leaf appearance rate and final leaf number of switchgrass cultivars. Crop Science 864-
870.

Keywords: leaf morphology

1295. Van Esbroeck, G. A., M. A. Hussey, and M. A. Sanderson. 1998. Selection response and development basis for early and late panicle emergence in Alamo switchgrass. Crop Science 38:342346.

Keywords: switchgrass

1296. Van Hook, R. I., D. W. Johnson, D. C. West, and L. K. Mann. 1982.

Environmental effects of harvesting forests for energy. Forest Ecology and

Management 4:79-94.

Keywords: environmental effects/ forests

1297. Van Volkenburgh, E., C. R. Ridge, and T. M. Hinckley. 1985. Limits to poplar leaf growth. Plant Physiology (Suppl.) 77:136.

Keywords: poplars/ leaf development

1298. Vaughan, D. H., J. S. Cundiff, and D. J. Parrish. 1988. Erosional and economic analyses of biomass production on marginal Piedmont sites. pp. 41-44. In Proceedings, Southern Biomass Conference. Auburn University, Auburn, Alabama. Keywords: energy crops/ soils/ sorghum/ harvesting/ land/ economics/ erosion

1299. Vaughan, D. H., J. S. Cundiff, and D. J. Parrish. 1989. Herbaceous crops on marginal sites - erosion and economics. Biomass 20(3-4):199-208.

Keywords: energy crops, herbaceous/ erosion/ economics

1300. Verburg, P. S. J., D. W. Johnson, and R. Harrison. 2001. Long-term nutrient cycling patterns in Douglas-fir and red alder stands: A simulation study. Forest Ecology and Management 145:203-217. Keywords: nutrient cycling/ Douglas-fir/ alders/ nitrogen fixation

1301. Verch, R. L. 1986. Nongame Breeding Bird Activity in an Intensively Cultured Populus Plantation. NC-336. U.S. 
Forest Service, North Central Forest Experiment Station, St. Paul, Minnesota. Keywords: agroforestry/ succession/ cottonwoods/ poplars/ birds/ habitat studies

1302. Villar, M., F. Lefevre, H. D. Bradshaw, Jr., and E. Teissier du Cros. 1996. Molecular genetics of rust resistance in poplars (Melampsora larici-populina Kleb./Populus sp.) by bulked segregant analysis in a $2 \times 2$ factorial mating design. Genetics 143:531-536.

Keywords: molecular genetics/ rust resistance/ poplars

1303. Vogel, K. P. 1996. Energy production from forages (or American agriculture-back to the future). Journal of Soil and Water Conservation 51(2):137-139. Keywords: crop production/ energy/ forage crops/ agriculture/ erosion

1304. Vogel, K. P. 2000. Improving warm-season grasses using selection, breeding, and biotechnology. pp. 83-106.

In Native Warm-Season Grasses: Research Trends and Issues. K. J. Moore and B. Anderson (eds.). Crop Science Society of America and American Society of Agronomy, Madison, Wisconsin. Keywords: grasses/ breeding/ biotechnology

1305. Vogel, K. P., K. Arumuganathan, and K. B. Jensen. 1999. Nuclear DNA content of perennial grasses of the triticeae. Crop Science 39(3):661-667.

Keywords: DNA/ perennials

1306. Vogel, K. P., J. J. Brejda, D. T. Walters, and D. R. Buxton. 2002.

Switchgrass biomass production in the midwest USA: Harvest and nitrogen management. Agronomy Journal 94(3):413420

Keywords: switchgrass/ crop management/ nitrogen/ harvesting

1307. Vogel, K. P., A. A. Hopkins, and

K. J. Moore. 1996. Registration of

'Shawnee' switchgrass. Crop Science
36(6): 1713.

Keywords: switchgrass/ Panicum virgatum

1308. Vogel, K. P., A. A. Hopkins, K. J. Moore, K. D. Johnson, and I. T. Carlson. 2002. Winter survival in switchgrass populations bred for high IVDMD. Crop Science 42:1857-1862.

Keywords: switchgrass/ survival/ populations/ digestibility

1309. Vogel, K. P., and H. G. Jung. 2001. Genetic modification of herbaceous plants for feed and fuel. Critical Reviews in Plant Science 20(1):15-49.

Keywords: genetic modification/ vegetation, herbaceous/fuels/ switchgrass/ Panicum virgatum

1310. Vogel, K. P., and R. A. Masters. 1998. Developing switchgrass into a biomass fuel crop for the Midwestern USA. pp. 1072-1080. In Bioenergy '98, Partnerships to Develop and Apply Biomass Technologies (Volumes I and II). Great Lakes Regional Biomass Energy Program, Muscle Shoals, Alabama.

Keywords: switchgrass/ Panicum virgatum/ biomass crops/ fuels

1311. Vogel, K. P., and R. A. Masters. 2001. Frequency grid: A simple tool for monitoring grassland establishment. Soc. Range Management 54:653-655.

Keywords: frequency grid/ grasslands/ establishment/ rangeland/ pasture/ plant density/ seedlings

1312. Vogel, K. P., R. A. Masters, P. J. Callahan, and K. Grams. 1998. Rotary processor for chaffy prairie grass seed. Journal of Range Management 51:536-539. Keywords: grass seed

1313. Vogel, K. P., J. F. Pedersen, S. D. Masterson, and J. J. Toy. 1999.

Evaluation of a filter bag system for NDF, ADF, and IVDMD forage analysis. Crop Science 39:276-279.

Keywords: forage crops 
1314. Volenec, J. J., and C. J. Nelson. 1995. Forage crop management:

Application of emerging technologies. pp. 3-20. In Forages: An Introduction to Grassland Agriculture. Iowa State University, Ames, Iowa.

Keywords: forage crops/ crop management/ genotypes

1315. Volk, T. A., L. P. Abrahamson, E. H. White, and M. E. Downing. 2000. Developing a Willow Biomass Crop Enterpise in the United States. pp. 49-56. In IEA Bioenergy: Task 17. Short-Rotation Crops for Bioenergy. L Christersson and L. L. Wright (eds.). ORNL/TM-2000/311. Oak Ridge National Laboratory, Oak Ridge, Tennessee.

Keywords: willows/ energy crops

1316. Volk, T. A., S. Edick, S. Brown, and M. E. Downing. 1999. Community outreach and education: Key components of the Salix consortium's willow biomass project. pp. 1733-1738. In Biomass, A Growth Opportunity in Green Energy and Value-Added Products - Proceedings of the 4th Biomass Conference of Americas. R. P. Overend and E. Chornet (eds.). Elsevier Science, Kidlington, Oxford, United Kingdom.

Keywords: willows/ biomass crops

1317. Volk, T. A., H. B. Shaw, and C. M. Westfall. 1998. In Enhancing the Productivity and Sustainability of ShortRotation Salicaceae. NYCFRD-98-04. SUNY, Syracuse, New York. Keywords: Salicaceae/ short rotation woody crops

1318. Walawender, W. P., C. S. Chia, and W. A. Geyer. 1988. Influence of tree species and wood deterioration on downdraft gasifier performance. Biomass 17:51-61.

Keywords: biomass energy/ gasification

1319. Walbridge, Jr., T. A., and W. B. Stuart. 1980. An alternative to whole tree chipping for the recovery of logging residues. pp. 132-138. In Proceedings, International Conference on Harvesting and Utilization for Energy. Swedish University of Agricultural Sciences, Uppsala, Sweden. Keywords: residues

1320. Walbridge, Jr., T. A., and W. B. Stuart. 1983. Systems and procedures for integrated recovery of forest biomass. TAPPI 66:89-97.

Keywords: crop management/ resources

1321. Walla, J. A., G. A. Tuskan, and J. E. Lundquist. 1997. Expression of inoculum and family specific responses in the ponderosa pine-western gall rust pathosystem. Plant Disease 81:57-62. Keywords: diseases/ Pinus ponderosa/ pines/genes

1322. Walla, J. A., C. Wang, C. M. Schumann, and G. A. Tuskan. 1998. Peridermium harknessii in the northcentral United States may be a complex of taxa. pp. 183-190. In Proceedings of the First IUFFRO Rusts of Forest Trees WP Conference. Research Papers 712. Finnish Forest Research Institute, Finland. Keywords: Pinus ponderosa/ taxonomy/ Peridermium harknessii

1323. Walsh, M. E. 1998. U.S. bioenergy crop economic analyses: Status and needs. Biomass and Bioenergy 14(4):341-350. Keywords: biomass crops/ economics/ willows, hybrid/ switchgrass/ Panicum virgatum/ poplars, hybrid/ short rotation woody crops

1324. Walsh, M. E. 2000. Method to estimate bioenergy crop feedstock supply curves. Biomass \& Bioenergy 18(4):283289.

Keywords: biomass energy/ resource assessment/ short rotation woody crops/ switchgrass/ Panicum virgatum/ feedstocks/ economics

1325. Walsh, M. E., and D. A. Becker. 1996. Biocost: A software program to estimate the cost of producing bioenergy 
crops. pp. 480-486. In Bioenergy '96, Partnerships to Develop and Apply Biomass Technologies.

Keywords: biomass crops/ economics/ energy crops/ models, BIOCOST

1326. Walsh, M. E., D. A. Becker, and R. L. Graham. 1996. The conservation reserve program as a means to subsidize bioenergy crop prices. pp. 75-81. In Bioenergy '96, Partnerships to Develop and Apply Biomass Technologies.

Keywords: bioenergy/ Conservation Reserve Program/ energy crops/ economics

1327. Walsh, M. E., D. G. De La Torre Ugarte, S. P. Slinsky, R. L. Graham, H. Shapouri, and D. E. Ray. 1998. Economic analysis of energy crop production in the U.S.: Location, quantitites, price and impacts on traditional agricultural crops. pp. 1302-1310. In BioEnergy '98, Proceedings of the 8th Biennial Conference. Great Lakes Regional Biomass Energy Program, Chicago, Illinois. Keywords: energy crops/ economics

1328. Walsh, M. E., P. J. Ince, D. G. De La Torre Ugarte, D. Adams, R. Alig, J. Mills, H. Spelter, K. Skog, S. P. Slinksy, D. E. Ray, and R. L. Graham. 1999. Potential of short rotation wood crops as a fiber and energy source in the U.S. pp. 6367. In Proceedings of the 4th Biomass Conference of the Americas: Biomass, A Growth Opportunity in Green Energy and Value-Added Products. R. P. Overend and E. Chornet (eds.). Elsevier Science, Ltd, Kidlington, Oxford, United Kingdom. Keywords: short rotation woody crops/ fiber/ energy/ economics

1329. Walsh, T. A., T. E. Burk, and J. G. Isebrands. 1990. Selection of hybrid poplar clones under varying moisture regimes: Preliminary results. pp. 323-330.

In Proceedings, Aspen Symposium '89. NC140. U.S. Forest Service, North Central Forest Experiment Station, Duluth, Minnesota.
Keywords: poplars, hybrid/ clonal selection/ physiology/ morphology/ phenology

1330. Walsh, T. A., T. E. Burk, and J. G. Isebrands. 1996. Development and evaluation of quantitative functions for early selection of Populus clones. Biomass and Bioenergy 11(2/3):151-159.

Keywords: Populus/ canonical correlation/ selection/ breeding/ short rotation woody crops/ moisture regimes/ multivariate techniques

1331. Wang, F. C., J. R. Richardson, K. C. Ewel, and E. T. Sullivan. 1981. Preliminary energy analysis of utilizing wood biomass for fuel. pp. 673-680. In Proceedings, 1981 International Symposium on Energy and Ecological Modeling. W. J. Mitsch, R. W. Bosserman, and J. M.

Klopatek (eds.). Elsevier Science Publishers Ltd., New York.

Keywords: short rotation woody crops/ fuels/ economics/ energy content

1332. Wang, S. 1983. Screening biomass species for methane production in Florida. Forest Products Journal 33:66-68.

Keywords: species selection/ Florida/ fuel properties

1333. Wang, S., and S. T. Chiang. 1983. Chemical properties of Melaleuca bark from south Florida. Economic Botany 37:16-21. Keywords: composition, chemical/

Melaleuca

1334. Wang, S., and J. B. Huffman.

1979. Effect of extractives on heat value of Melaleuca. Forest Products Research Society Abstracts 33:6.

Keywords: Melaleuca/ extractives/ heating values/ conversion technologies

1335. Wang, S., and J. B. Huffman. 1981. Botanochemicals: Supplements to petrochemicals. Economic Botany 35:369382.

Keywords: botanochemicals/ biomass crops/ fuels 
1336. Wang, S., and J. B. Huffman. 1982. Effect of extractives on heat content of Melaleuca and Eucalyptus. Wood Science 15:33-38.

Keywords: conversion technologies/ Melaleucal Eucalyptus/ extractives/ heating values

1337. Wang, S., J. B. Huffman, and R. C. Littell. 1981. Characterization of Melaleuca biomass as a fuel for direct combustion. Wood Science 13:216-219. Keywords: conversion technologies/ wood/ moisture content/ Melaleuca

1338. Wang, S., J. B. Huffman, and D. L. Rockwood. 1982. Qualitative evaluation of fuelwood in Florida: A summary report. Economic Botany 36:381-388.

Keywords: pines/ Melaleucal Eucalyptus/ Casuarinal fuel properties

1339. Wang, S., and R. C. Littell. 1983. Phenotypic variation in calorific value of Melaleuca materials from south Florida. Economic Botany 37:292-298. Keywords: Melaleuca/ calorimetry

1340. Wang, S., R. C. Littell, and D. L. Rockwood. 1984. Variation in density and moisture content of wood and bark among 20 Eucalyptus grandis progenies. Wood Science Technology 18:97-100.

Keywords: Eucalyptus grandis/moisture content/ wood

1341. Ward, K. T., and M. E. Ostry. 1993. Mid-rotation disease impact on hybrid poplar plantations in the north-central United States. American Journal of Botany 80:83.

Keywords: short rotation woody crops/ renewable energy/ poplars/ hybrids/ Melampsoral diseases

1342. Ward, K. T., M. E. Ostry, and G. R. Furnier. 1992. Genetic and pathogenic variability of Septoria musiva. pp. 62. In Proceedings of the Twelfth North American Forest Biology Workshop. S. J. Colombo, G. Hogan, and V. Wearn (eds.).
Ontario Ministry of Natural Resources, Ontario, Canada.

Keywords: genetics/ pathogens/Septoria musiva/ poplars, hybrid/ poplars/ stem cankers/ defoliation/ clonal propagation

1343. Ward, K. T., M. E. Ostry, and G. R. Furnier. 1994. Morphological and molecular genetic variation among isolates of Septoria musiva. Phytopathology 84:1145.

Keywords: genetic variations/ Septoria musiva/ morphology

1344. Warmund, M. R., W. A. Geyer, and C. E. Long. 1983. Preemergent herbicides for direct seeding Kentucky coffeetree, honeylocust, and black locust. Tree Planters' Notes 33:24-27.

Keywords: herbicides/ establishment/ Kentucky coffeetree/ honeylocusts/ locusts, black/ Gleditsia triacanthos/ Robinia pseudoacacial Gymnocladus diocia

1345. Warmund, M. R., C. E. Long, and W. A. Geyer. 1980. Preemergent herbicides for seeded nursery crops. Journal of Horticultural Science 15:825826.

Keywords: herbicides/ establishment/ nursery, forest

1346. Warrag, E. I. , V. Ortega, M. S. Lesney, and D. L. Rockwood. 1988. Recent progress in tissue culture methods for Eucalyptus species and implications for genetic improvement. pp. 71-80. In Proceedings of the 1987 Southern Forest Biomass Workshop: 9th Annual Meeting of the Southern Forest Biomass Working Group. R. A. Daniels, W. F. Watson, and I. W. Savelle (eds.). Mississippi State University, Biloxi, Mississippi. Keywords: tissue culture/ genetic modification/ callus/ embryogenesis/ Eucalyptus grandis/ Eucalyptus camaldulensis

1347. Weaver, A., R. S. Saini, S. Bhattacharya, A. Mauldin, D. P. Nicholson, S. Nima, M. Baiyee, and 
M. Randolph. 1990. Effects of various nitrogen fertilization on growth responses of sycamore (Platanus occidentalis L.) plantation. pp. 19. In International Symposium on Natural Resources Management for a Sustainable Agriculture. Indian Society of Agronomy, New Delhi. Keywords: fertilization/ growth/ growth/ sycamores

1348. Weaver, A., R. S. Saini, S. Bhattacharya, A. Mauldin, D. P. Nicholson, S. Nima, M. Baiyee, and M. Randolph. 1990. Physiological responses of trees to urea nitrogen fertilization in a short-rotation sycamore (Platanus occidentalis L.) plantation. pp. 19. In International Symposium on Natural Resources Management for a Sustainable Agriculture. Indian Society of Agronomy, New Delhi.

Keywords: fertilization/growth responses/ sycamores

1349. Weber, J. C., and R. F. Stettler. 1981. Isoenzyme variation among the populations of Populus trichocarpa (Torr. \& Gray) in the Pacific Northwest. Silvae Genetica 30:82-87.

Keywords: Populus trichocarpa

1350. Weber, J. C., R. F. Stettler, and P. E. Heilman. 1985. Genetic variation and productivity of Populus trichocarpa and its hybrids. I. Morphology and phenology of 50 native clones. Canadian Journal of Forest Research 15:376-383.

Keywords: poplars/ hybrids/ morphology/ phenology/ clonal propagation/ genetic variations

1351. Webley, O. J. , T. F. Geary, D. L. Rockwood, C. W. Comer, and G. F. Meskimen. 1986. Seasonal coppicing variation in three eucalypts in southern Florida. Australian Forest Research 16:281-90.

Keywords: Eucalyptus/ coppice/ harvesting

1352. West, D. C., and L. K. Mann. 1982. Whole-tree Harvesting: Third Year Progress
Report for 1981: Nutrient Depletion Estimates and Post-harvest Impacts on Nutrient Dynamics. ORNL/TM-8335. Oak Ridge National Laboratory, Oak Ridge, Tennessee.

Keywords: harvesting/ nutrient cycling/ whole-tree

1353. West, D. C., and L. K. Mann. 1983. Whole-tree Harvesting: Fourth Year Progress Report for 1982 - Nutrient Depletion Estimates, Postharvest Impacts on Nutrient Dynamics, and Regeneration. ORNL/TM-8805. Oak Ridge National Laboratory, Oak Ridge, Tennessee. Keywords: whole-tree/ productivity/ nutrient cycling/ environmental effects/ regeneration

1354. West, D. C., L. K. Mann, and N. T. Edwards. 1981. Whole-tree Harvesting: Second Year Progress Report - Impacts on Forest Nutrient and Carbon Dynamics. ORNL/TM-7874. Oak Ridge National Laboratory, Oak Ridge, Tennessee.

Keywords: harvesting/ nutrients/ carbon/ whole-tree

1355. Wetzstein, H. Y., N. Lee, and H. E. Sommer. 1984. Differentiation of tissue cultured Liquidambar styraciflua in agar versus liquid medium. Journal of Horticultural Science 19:556.

Keywords: Liquidambar styraciflua/ tissue culture

1356. Wetzstein, H. Y., and H. E. Sommer. 1983. Root anatomy in tissue cultured Liquidambar styraciflua L. Journal of Horticultural Science 18:172.

Keywords: Liquidambar styraciflua/ roots/ morphology

1357. Wetzstein, H. Y., and H. E. Sommer. 1983. Scanning electron microscopy of in vitro cultured Liquidambar styraciflua plantlets during acclimatization.

Journal of American Society for Horticultural Science 108:475-480.

Keywords: Liquidambar styraciflual scanning electron microscopy/ morphology 
1358. Wetzstein, H. Y., H. E. Sommer, C. L. Brown, and H. M. Vines. 1981.

Anatomical changes in tissue-cultured sweetgum leaves during the hardening-off period. Journal of Horticultural Science 16:290.

Keywords: sweetgum/ morphology/ leaf development

1359. White, E. H., L. P. Abrahamson, R. F. Kopp, and C. A. Nowak. 1992.

Bioenergy plantations in New York: 10-year results. The Forestry Chronicle 68:221.

Keywords: plantations/ New York/ biomass crops/ agroforestry/ carbon sequestration/ poplars, hybrid/ willows/ genetics/ irrigation/ fertilization

1360. White, E. H., L. P. Abrahamson, R. F. Kopp, and C. A. Nowak. 1993. Willow bioenergy plantation research in the northeast. pp. 199-213. In Proceedings I, First Biomass Conference of the Americas: Energy, Environment, Agriculture, and Industry. National Renewable Energy Laboratory, Golden, Colorado. Keywords: willows/ energy crops/ plantations/ biomass crops/ Salix

1361. White, E. H., and R. L. Gambles. 1988. Experiences with Willow as a Wood Biomass Species. Bio-Joule 4-7.

Keywords: willows/ wood/ biomass crops

1362. White, T. A., and G. L. Rolfe. 1980. Stand establishment and maintenance of woody biomass species: 1979 herbicide trials. Illinois Agricultural Experiment Station DSAC 8:171-175.

Keywords: establishment/ crop management/ herbicides

1363. White, T. A., and G. L. Rolfe. 1982. Tolerance of direct-seeded black locust (Robinia pseudoacacia L.) to herbicides. Illinois Agricultural Experiment Station Forest Research Reports 82:5. Keywords: locusts, black/ herbicides/ stress

1364. White, T. A., and G. L. Rolfe. 1983. A test of tolerance: 1982 greenhouse herbicide trials with direct-seeded black locust. Illinois Agricultural Experiment Station Forest Research Reports 83-2:5. Keywords: herbicides/ locusts, black

1365. White, T. A., and G. L. Rolfe. 1984. Comparative energy costs of stem cuttings, seedlings, and seeds as propagules in woody biomass plantations. Biomass 5:55-64.

Keywords: crop management/ energy balance/ seedlings/ seed/ stems

1366. White, T. A., G. L. Rolfe, and L. E. Arnold. 1983. Home-grown firewood. Illinois Research 25:9-10.

Keywords: fuelwood

1367. White, T. A., G. L. Rolfe, and D. R. Bluhm. 1981. Energy production from direct-seeded woody biomass. Illinois Agricultural Experiment Station DSAC 9:249-252.

Keywords: seed/ woody crops/ energy

1368. White, T. A., G. L. Rolfe, and D. R. Bluhm. 1981. Establishment of woody biomass plantations in the Midwest: 1980 herbicide trials. Illinois Agricultural Experiment Station DSAC 9:236-246. Keywords: herbicides/ establishment/ short rotation woody crops

1369. White, T. A., G. L. Rolfe, and D. R. Bluhm. 1982. Effects of herbicides on tolerance of woody biomass species and control of weeds in southern Illinois: 1980 herbicide trials. Illinois Agricultural Experiment Station Forest Research Reports 82:6.

Keywords: herbicides/ stress/ weed control/ woody crops

1370. White, T. A., G. L. Rolfe, and D. R. Bluhm. 1982. Effects of some preemergent herbicides on survival and tolerance of various woody biomass species: 1979 herbicide trials. Illinois Agricultural Experiment Station Forest Research Reports 82:4 
Keywords: herbicides/ stress/ woody crops/ weed control

1371. White, T. A., G. L. Rolfe, J. J. Faix, and R. W. Zimmerman. 1979. Pilot studies of woody biomass for energy. Illinois Agricultural Experiment Station DSAC 7:221-225.

Keywords: short rotation woody crops/ radiation, solar/ ethanol/ methanol/ natural gas

1372. Whitesell, C. D. 1980. Eucalyptus research for generating bioenergy: A 2-year progress report. pp. 71-73. In Proceedings, Hawaii Forestry Wildlife Conference: Moving Forestry and Wildlife into the 80's. U.S. Forest Service, Pacific Southwest Forest and Range Experiment Station, Berkeley, California.

Keywords: Eucalyptus

1373. Whitesell, C. D., D. S. Debell, and T. H. Schubert. 1988. Six-year Growth of Eucalyptus saligna Plantings as Affected By Nitrogen and Phosphorus Fertilizer. PSW-

188. U.S. Forest Service, Pacific Southwest Forest and Range Experiment Station, Berkeley, California.

Keywords: Eucalyptus saligna/ Hawaii/ fertilization/ nitrogen/ phosphorus/ biomass crops

1374. Whitesell, C. D., D. S. DeBell, T. H. Schubert, R. F. Strand, and T. B. Crabb. 1992. Short-rotation Management of Eucalyptus: Guidelines for Plantations in Hawaii. PSW-GTR-137. U.S. Department of Agriculture Pacific Southwest Research Station, Albany, California.

Keywords: short rotation woody crops/ crop management/ Eucalyptus/ plantations/ Hawaii

1375. Whitesell, C. D., and S. C. Miyasaka. 1981. Fertilization for biomass production. pp. 30-32. In Proceedings, 14th Hawaii Fertilizer Conference. Research Extension Series 005. University of Hawaii at Manoa, College of Tropical Agriculture and Human Resources, Manoa,
Hawaii.

Keywords: fertilization/ nutrients

1376. Whitesell, C. D., S. C. Miyasaka, R. F. Strand, T. H. Schubert, and K. E. McDuffie. 1988. Equations for Predicting Biomass in 2 to 6-year-old Eucalyptus saligna in Hawaii. PSW-402. U.S. Forest Service, Pacific Southwest Forest Experiment Station, Berkeley, California. Keywords: Eucalyptus/ biomass crops/ short rotation woody crops/ silviculture

1377. Widin, K. D., and A. L. Schipper, Jr. 1980. Epidemiology of Melampsora medusae leaf rust of poplars in the north central United States. Canadian Journal of Forest Research 10:257-263.

Keywords: diseases/ poplars, hybrid/ rusts/ Melampsora medusae

1378. Widin, K. D., and A. L. Schipper, Jr. 1981. Effect of Melampsora medusae leaf rust infection on yield of hybrid poplars in the north central United States. European Journal of Forestry Pathology 11:438-448. Keywords: poplars, hybrid/ rusts/ Melampsora medusael diseases

1379. Wightman, S. J., and P. Felker. 1990. Soil and foliar characterization for Prosopis clones on sites with contrasting productivity in semi-arid south Texas. Journal of Arid Environments 18:351-365. Keywords: soils/ Prosopis/ Texas/ reforestation

1380. Williford, M., R. C. Kellison, D. J. Frederick, and W. E. Gardner. 1979.

The use and selection of trees for energy and chemicals. pp. 149-155. In Proceedings, 15th Southern Forest Tree Improvement Conference. Mississippi State University, Biloxi, Mississippi.

Keywords: short rotation woody crops/ byproducts/ plantations/ species selection/ site selection

1381. Wiselogel, A. E., F. A. Agblevor, D. K. Johnson, S. Deutch, J. A. Fennell, and M. A. Sanderson. 1996. Bioresource 
Technology 56:103-109.

Keywords: switchgrass/ Panicum virgatum/ biomass crops/ cellulose/ hemicellulose/ lignin/ extractives/ storage

1382. Wiselogel, A. E., H. H. Chum, R. P. Overend, and J. H. Cushman. 1992.

Poplars for fuel, power, and chemicals: The interface between production and conversion technologies. The Forestry Chronicle 68:220.

Keywords: poplars/ fuels/ conversion technologies/ commercialization/ feedstocks

1383. Wittwer, R. F., and M. J. Immel. 1980. Chemical composition of five deciduous tree species in four-year-old, closely spaced plantations. Plant and Soil 54:461-467.

Keywords: Alnus glutinosal Betula nigral Fraxinus pennsylvanica/ nutrient cycling/ Platanus occidentalis/ poplars/ species selection/ composition, chemical

1384. Wittwer, R. F., M. J. Immel, and F. R. Ellingsworth. 1980. Nutrient uptake in fertilized plantations of American sycamore. Soil Science Society of America Journal 44:606-610.

Keywords: Platanus occidentalis/ nutrient cycling/ fertilization/ short rotation woody crops/sycamores/ potassium/ calcium/ magnesium/ manganese

1385. Wolf, A. T., T. E. Burk, and J. G. Isebrands. 1991. Sampling schemes for estimating total-tree photosynthesis in Populus clones: A modeling approach. pp. 130-139. In Forestry Futures, Proceedings of Midwestern Forest Mensurationists, Great Lakes Forest Growth and Yield Cooperative, and the Forestry Canada Modeling Working Group Joint Workshop. B. Payandeh (ed.). Forestry Canada, Canada.

Keywords: photosynthesis/ poplars/ clonal propagation/models/ ecophysiology/ models, ECOPHYS
1386. Wolf, A. T., T. E. Burk, and J. G. Isebrands. 1995. Estimation of daily and seasonal whole-tree photosynthesis using Monte Carlo integration techniques.

Canadian Journal of Forest Research 25:253-260.

Keywords: photosynthesis

1387. Wolf, A. T., T. E. Burk, and J. G. Isebrands. 1995. Evaluation of sampling schemes for estimating instantaneous wholetree photosynthesis in Populus clones: A modeling approach. Tree Physiology 15:237-244.

Keywords: models, ECOPHYS/ leaf orientation/ photosynthesis/ poplars

1388. Wolf, D. D., and D. J. Parrish. 1995. Switchgrass establishment in the East: Successes and problems. Agronomy Abstracts 108.

Keywords: switchgrass/ Panicum virgatum/ biofuels

1389. Wolf, D. D., D. J. Parrish, W. L. Daniels, and J. R. McKenna. 1988. Notill establishment of perennial tall-growing warmseason grasses for biomass production. pp. 40-43. In Proceedings, Southern Biomass Conference. Auburn University, Auburn, Alabama.

Keywords: energy crops/ soils/ sorghum/ harvesting/ land/ no-till/ energy crops, herbaceous

1390. Woo, S.-Y. 1997. Inheritance patterns of physiological response to ozone exposure on poplar pedigree (Populus trichocarpa $\times$ Populus deltoides). pp. 6163. In Proceedings of the Korean Forestry Society Meetings.

Keywords: Populus/ poplars/ ozone

1391. Wood, B., and J. W. Hanover. 1981. Accelerating the growth of black walnut seedlings. Tree Planters' Notes 32:35-38.

Keywords: walnuts, black/ growth responses 
1392. Woods, R. F., and J. W. Hanover. 1983. Growth characteristics of Imperial Carolina poplar over a range of soil types. Tree Planters' Notes 33:8-13.

Keywords: poplars/ soil types/ growth responses

1393. Woods, R. F., L. M. Moore, L. F. Wilson, M. E. Ostry, and D. I. Dickmann. 1982. Performance of 3-year-old hybrid poplar clones in relation to soil texture, natural soil drainage, and pest incidence. pp. 74-83. In Proceedings, 1982 North American Poplar Council Meeting. J. Zavitkovski and E. A. Hansen (eds.). Kansas State University, Manhattan, Kansas.

Keywords: poplars, hybrid/ growth responses/ soil properties/ pests

1394. Wray, P. H. 1984. Tree Planting in Iowa. Pm-496. Iowa State University, Ames, Iowa.

Keywords: Iowa/ establishment

1395. Wright, L. L. 1988. Are increased yields in coppice systems a myth? In Proceedings, Energy from Biomass and Wastes XI. D. L. Klass (ed.). Institute of Gas Technology, Chicago, Illinois.

Keywords: coppice/ yields

1396. Wright, L. L. 1988.

Commercialization of short-rotation intensive culture tree production in North America. pp. 309-328. In Proceedings, Energy from Biomass and Wastes XIII. D. L. Klass (ed.). Institute of Gas Technology, Chicago, Illinois. Keywords: industry/ economics/ short rotation woody crops

1397. Wright, L. L. 1991. Biomass energy crop development. pp. 151. In Abstracts of XVII Pacific Science Congress. University of Hawaii, Honolulu, Hawaii. Keywords: biomass crops

1398. Wright, L. L. 1991. The economic viability of short rotation woody crops. pp. 21. In Policy Implications of Greenhouse
Warming Report of the Mitigation Panel. Appendix H: Biomass. National Academy Press, Washington, DC.

Keywords: economics/ short rotation woody crops

1399. Wright, L. L. 1991. Role of new wood energy crops in mitigation of fossil $\mathrm{CO}_{2}$ emissions. pp. 87-112. In Proceedings, 1990 Conference on Biomass for Utility Applications. Electric Power Research Institute, Palo Alto, California. Keywords: climate/ environmental effects

1400. Wright, L. L. 1994. Dedicated feedstock supply systems. Biomass and Bioenergy 6(3):159.

Keywords: feedstocks/ renewable energy/ energy crops

1401. Wright, L. L. 1994. Production technology status of woody and herbaceous crops. Biomass and Bioenergy 6(3):191209.

Keywords: production systems/ woody crops/ energy crops, herbaceous

1402. Wright, L. L. 1995. Demonstration and commercial production of biomass for energy. pp. 1-10. In Second Biomass Conference of the Americas. National Renewable Energy Laboratory, Golden, Colorado.

Keywords: production/ biomass crops/ energy/ commercialization

1403. Wright, L. L. 1999. Short-Rotation Crops in the United States. pp. 53-61. In Short-Rotation Crops for Energy Purposes, Proceedings of the First Meeting of IEA, Bioenergy, Task 17. L. Christersson and S. Ledin (eds.). Swedish University of Agricultural Sciences, Uppsala, Sweden. Keywords: short rotation woody crops/ woody crops/ energy crops, herbaceous

1404. Wright, L. L., and S. Berg. 1996. Industry/government collaborations on short-rotation woody crops for energy, fiber and wood products. pp. 508-514. In Bioenergy '96, Partnerships to Develop and 
Apply Biomass Technologies.

Keywords: industry/ government/ short rotation woody crops/ commercialization/ sustainable forestry

1405. Wright, L. L., and J. H. Cushman. 1997. A national research and development strategy for biomass crop feedstocks. pp. 109-118. In Third Biomass Conference of the Americas: Energy, Environment, Agriculture, and Industry. Elsevier. Keywords: biomass energy/ dedicated feedstock supply systems/ residues/ byproducts/ coproducts

1406. Wright, L. L., J. H. Cushman, A. R. Ehrenshaft, S. B. McLaughlin, S. A. Martin, W. A. McNabb, J. W. Ranney, G. A. Tuskan, and A. F. Turhollow. 1993. Biofuels Feedstock Development Program Annual Progress Report for 1992. ORNL6781. Oak Ridge National Laboratory, Oak Ridge, Tennessee.

Keywords: biofuels/ feedstocks/ woody crops/ genetic modification/ species selection/ energy crops, herbaceous/ environmental effects/ economics

1407. Wright, L. L., J. H. Cushman, A. R. Ehrenshaft, S. B. McLaughlin, W. A. McNabb, J. W. Ranney, G. A. Tuskan, and A. F. Turhollow. 1992. Biofuels Feedstock Development Program Annual Progress Report for 1991. ORNL6742. Oak Ridge National Laboratory, Oak Ridge, Tennessee.

Keywords: biofuels/ feedstocks/ birds/ woody crops/ genetic modification/ species selection/ energy crops, herbaceous/ environmental effects/ economics

1408. Wright, L. L., J. H. Cushman, and S. A. Martin. 1994. The biomass resource potential of energy crops. pp. 261-267. In Alternative Fuels and the Environment. F. S. Sterrett (ed.). CRC Press, Inc., Boca Raton, Florida.

Keywords: biomass crops/ energy crops/ feedstocks
1409. Wright, L. L., D. S. DeBell, C. H. Strauss, W. A. Geyer, L. SennerbyForsse, and L. Zsuffa. 1989. Panel discussion on the relative merits of woodgrass and SRIC. pp. 261-274. In Proceedings, Energy from Biomass and Wastes XII. D. L. Klass (ed.). Institute of Gas Technology, Chicago, Illinois.

Keywords: planting density/ short rotation intensive culture

1410. Wright, L. L., T. W. Doyle, P. A. Layton, and J. W. Ranney. 1989. Short Rotation Woody Crops Program: Annual Progress Report for 1988. ORNL-6594. Oak Ridge National Laboratory, Oak Ridge, Tennessee.

Keywords: genetics/ productivity/ biomass crops/ biotechnology/ environmental effects/ monoculture

1411. Wright, L. L., and A. R. Ehrenshaft. 1990. Short Rotation Woody Crops Program: Annual Progress Report for 1989. ORNL-6625. Oak Ridge National Laboratory, Oak Ridge, Tennessee.

Keywords: biomass crops/ economics/ short rotation woody crops/ species selection/ genetic modification/ physiology

1412. Wright, L. L., R. L. Graham, and A. F. Turhollow. 1990. Short-rotation woody crop opportunities to mitigate carbon dioxide buildup. pp. 137-156. In North American Conference on Forestry Responses to Climate Change. Climate Institute, Washington, DC.

Keywords: fuels, fossil/ carbon/ short rotation woody crops/ economics/ crop management/ land

1413. Wright, L. L., R. L. Graham, A. F. Turhollow, and B. C. English. 1992. The potential impacts of short-rotation woody crops on carbon conservation. pp. 123-156. In Forests and Global Change, Chapter 8. R. N. Sampson and D. Hair (eds.).

American Forestry Association, Washington, DC.

Keywords: fuels, fossil/ yields/ land/ short rotation woody crops/ carbon dioxide 
1414. Wright, L. L., and R. B. Hall. 1991. Overview of biofuels feedstock development work in the United States. pp. 26-32. In International Energy Agency 1991 Joint Meeting of the Task V Activity Groups and Workshop of the Task II Activity Group. R. B. Hall, R. D. Hanna, and R. N. Nyong'o (eds.). Iowa State University Press, Ames, Iowa.

Keywords: biofuels/ feedstocks/ short rotation woody crops/ productivity

1415. Wright, L. L., and E. E. Hughes. 1993. U.S. carbon offset potential using biomass energy systems. Water, Air, and Soil Pollution 70:483-497.

Keywords: biomass crops/ carbon

1416. Wright, L. L., and E. E. Hughes. 1993. Water, Air, and Soil Pollution 70:483-497.

Keywords: carbon/ biomass crops/ emissions/ energy, fossil/ short rotation woody crops/ fuels/ electricity/ feedstocks

1417. Wright, L. L., and L. A. Kszos. 2000. Bioenergy Status and Expansion in the United States. pp. 57-65. In IEA Bioenergy: Task 17. Short-Rotation Crops for Bioenergy. L Christersson and L. Wright (eds.). ORNL/TM-2000/311. Oak Ridge National Laboratory, Oak Ridge, Tennessee.

Keywords: energy/ policy

1418. Wright, L. L., P. A. Layton, and J. W. Ranney. 1988. Development of a research strategy for poplar. pp. 11-28. In Culture to the Year 2000: Proceedings of the Poplar Council of the U.S. and Canada. B. A. Barkely and G. McVey (eds.). Fast Growing Forest Group, Ontario Natural Resource, Brockville, Ontario, Canada. Keywords: poplars/ genetic modification/ crop management/ operational considerations

1419. Wright, L. L and R. D. Perlack. 2000. Bioenergy Developments. Energy Efficiency Journal 8(1):27-28.
Keywords: bioenergy/ fuels/ economics/ biomass crops

1420. Wright, L. L., and J. W. Ranney. 1988. Validation and standardization of SRIC (short-rotation intensive culture) production costs. pp. 230-237. In Proceedings, IEA/BA Task II Workshop: Economic Evaluations of Short Rotation Biomass Systems. D. C. Lothner, D. P. Bradley, and R. L. Gambles (eds.). University of Toronto, Duluth, Minnesota. Keywords: economics/ short rotation intensive culture

1421. Wright, L. L., and J. W. Ranney. 1992. Short rotation woody crops: Using agroforestry technology for energy in the United States. pp. 139-154. In Proceedings in the 2nd Annual Brazilian Conference on Forest Economics and Planning. L. R. Graca (ed.).

Keywords: short rotation woody crops/ agroforestry/ energy

1422. Wright, L. L., and K. Shaw. 1994. Bioenergy. pp. 61-62. In The Encyclopedia of the Environment. S. Boulanger (ed.). Houghton Mifflin Company, New York. Keywords: biomass crops/ environmental effects

1423. Wright, L. L., and A. F. Turhollow. 1990. New energy crops. pp. 87-111. In Proceedings, 1990 Conference on Biomass for Utility Applications. Electric Power Research Institute, Palo Alto, California. Keywords: carbon/ energy crops/ land

1424. Wright, L. L., and G. A. Tuskan. 1997. Strategy, Results and Directions for Woody Crop Research Funded by the US Department of Energy. pp. 791-799. In 1997 Pulping Conference. TAPPI, Atlanta, Georgia.

Keywords: short-rotation woody crops/ energy

1425. Wright, N. 1990. Screening of Herbaceous Species for Energy Crop Production. Final Report 1985-1990. 
ORNL/Sub/85-27411/5. Oak Ridge

National Laboratory, Oak Ridge, Tennessee.

Keywords: species selection/ soil types/

yields/ crop management

1426. Wu, R. 1993. Simulated optimal structure of a photosynthetic system: Implications for the breeding of forest crop ideotype. Canadian Journal of Forest Research 23:1631-1638.

Keywords: photosynthesis/ breeding/ forests/ ideotype

1427. Wu, R. 1994. Quantitative genetics of yield breeding for Populus short rotation culture. II. Genetic determination and expected selection response of tree geometry. Canadian Journal of Forest Research 24:155-165.

Keywords: genetics/ breeding/ Populus/ poplars/ short rotation woody crops

1428. Wu, R. 1994. Quantitative genetics of yield breeding for Populus short rotation culture. III. Expected efficiency of indirect selection for tree geometry. Theoretical and Applied Genetics 88:803-811.

Keywords: genetics/ breeding/ Populus/ poplars/ short rotation woody crops

1429. Wu, R. 1995. A quantitative genetic model for mixed diploid and triploid progenies in tree breeding and evolution.

Theoretical and Applied Genetics 90:683690.

Keywords: genetics/ breeding

1430. Wu, R. 1996. Detecting epistatic genetic variance with a clonally replicated design: Model for low- vs. high-order nonallelic interactions. Theoretical and Applied Genetics 93:102-109.

Keywords: genetics

1431. Wu, R. 1996. Quantitative genetic dissection of complex traits in a QTLmapping pedigree. Theoretical and Applied Genetics 93:447-457.

Keywords: genetics/ quantitative trait loci (QTL)
1432. Wu, R., Jr., H. D. Bradshaw, and

R. F. Stettler. 1997. Molecular genetics of growth and development of Populus

(Salicaceae). V. Mapping quantitative trait loci affecting leaf variation. American Journal of Botany 84(2):143-153.

Keywords: growth/ leaves/ map, linkage/ Populus/ quantitative trait loci (QTL)/ mapping/ Salicaceae

1433. Wu, R., H. D. Bradshaw, Jr., and R. F. Stettler. 1998. Developmental quantitative genetics of growth in Populus. Theor. Appl. Genetics 97:1110-1119.

Keywords: genetic correlations/ growth/

Populus/ quantitative trait loci (QTL)/ seedlings

1434. Wu, R., and R. F. Stettler. 1995.

Quantitative genetics of growth and development in Populus. I. A threegeneration comparison of tree architecture during the first two years of growth.

Theoretical and Applied Genetics 88:10461054.

Keywords: genetics/ poplars/ growth/ tree architecture/ branch

1435. Wu, R., and R. F. Stettler. 1996. The genetic resolution of juvenile canopy structure and function in a three-generation pedigree of Populus. Trees 11:99-108. Keywords: genetics/ Populus

1436. Wu, R., and R. F. Stettler. 1996. Quantitative genetics of growth and development in Populus. II. The partitioning of genotype $\times$ environment interaction in stem growth. Heredity 78:124-134.

Keywords: genetics/ poplars/ growth/ tree architecture

1437. Wu, R., and R. F. Stettler. 1997. Quantitative genetics of growth and development in Populus. II. The partitioning of genotype $\times$ environment interaction in stem growth. Heredity 78:124-134.

Keywords: genetics/ poplars/ genotypes/ environmental sensitivity/genetic correlations/ growth/ Populus/ heritability 
1438. Wu, R., and R. F. Stettler. 1998.

Quantitative genetics of growth and development in Populus. III. Phenotypic plasticity of crown structure and function. Heredity 81:299-310.

Keywords: genetics/ poplars/ growth/ tree architecture/ branch

1439. Wu, R., M. Wang, and M. Huang. 1992. Quantitative genetics of yield breeding for Populus short rotation culture. I. Dynamics of genetic control and selection model of yield traits. Canadian Journal of Forest Research 22:175-182.

Keywords: genetics/ breeding/ Populus/ poplars/ short rotation woody crops

1440. Wullschleger, S. D., F. C. Meinzer, and R. A. Vertessy. 1998. A review of whole-plant water use studies in trees. Tree Physiology 18:499-512.

Keywords: cavitation/ hydrology/ hydraulic conductance/ sap flow/ scaling/ stomata/ transpiration/ water storage

1441. Wullschleger, S. D., M. A. Sanderson, S. B. McLaughlin, D. P. Biradar, and A. L. Rayburn. 1996. Photosynthetic rates and ploidy levels among populations of switchgrass. Crop Science 36:306-312.

Keywords: photosynthesis/ switchgrass/ Panicum virgatum/ ploidy level/ hexaploid

1442. Yost, R. S., D. S. DeBell, C. D. Whitesell, and S. C. Miyasaka. 1987. Early growth and nutrient status of Eucalyptus saligna as affected by nitrogen and phosphorus fertilization. Australian Forest Research 17:203-214.

Keywords: Eucalyptus salignal Eucalyptus/ fertilization/growth responses

1443. Young, K. R., H. S. McNabb, Jr., and M. E. Ostry. 1980. Aerial pathogens in a central Iowa poplar plantation. Iowa Academy of Science Proceedings 87:6. Keywords: poplars/ diseases

1444. Zarges, R. V., R. D. Newman, and J. B. Crist. 1980. Kraft pulp and paper properties of Populus clones grown under short rotation intensive culture. TAPPI 63:91-94.

Keywords: Populus/ paper/ pulpwood

1445. Zavitkovski, J. 1979. Energy production in irrigated, intensively cultured plantations of Populus 'Tristis \#1' and jack pine. Forest Science 25:383-392.

Keywords: Pinus banksiana/ biomass crops/ calorimetry/ energy/ whole-tree/ Populus/ irrigation

1446. Zavitkovski, J. 1981. Small plots with unplanted plot border can distort data in biomass production studies. Canadian Journal of Forest Research 11:9-12. Keywords: poplars/ edge effect

1447. Zavitkovski, J. 1981. Some promising forest ecosystems of the temperate zone for biomass production and energy storage. pp. 129-143. In Proceedings, Energy from Biomass and Wastes V. Institute of Gas Technology, Chicago, Illinois.

Keywords: ecosystems/ forests

1448. Zavitkovski, J. 1981. Structure and seasonal distribution of litterfall in young plantations of Populus 'Tristis \#1'. Plant and Soil 60:321-504.

Keywords: photosynthesis/ fertilization/ irrigation/ leaf area/ leaf fall/ poplars/ Wisconsin/ Populus tristis

1449. Zavitkovski, J. 1982.

Characterization of light climate under canopies of intensively-cultured hybrid poplar plantations. Agricultural Meteorology 25:245-255.

Keywords: photosynthesis/ light/ crown architecture/ poplars, hybrid/ radiation, solar/ quantum sensors

1450. Zavitkovski, J. 1982. Juvenile coppice growth and production of several hybrid poplars in northern Wisconsin. pp. 103-112. In Proceedings, 1982 North American Poplar Council Meeting. J. Zavitkovski and E. A. Hansen (eds.). 
Kansas State University, Manhattan,

Kansas.

Keywords: coppice/ survival rate/ growth/ productivity/ poplars, hybrid

1451. Zavitkovski, J., E. A. Hansen, and H. A. McNeel. 1979. Nitrogen-fixing species in short rotation systems for fiber and energy production. pp. 388-402. In Symbiotic Nitrogen Fixation in the Management of Temperate Forests. J. C. Gordon, C. T. Wheeler, and D. A. Perry (eds.). Oregon State University, Forestry Research Laboratory, Corvallis, Oregon. Keywords: nitrogen fixation/ short rotation woody crops/ fiber

1452. Zavitkovski, J., and J. G.

Isebrands. 1983. Biomass production and energy accumulation in the world's forests.

pp. 12-22. In The Seventh International Forest Products Research Society Industrial Wood Energy Forum '83 -- Proceedings 47337. Forest Products Research Society, Madison, Wisconsin.

Keywords: photosynthesis/ conversion/ biomass energy/ biomass crops/ energy content/ forests/ oil/ tropical zone

1453. Zavitkovski, J., and T. F. Strong. 1982. How to Grow and Use Hybrid Poplar Firewood. Pamphlet HT-54. U.S. Forest Service, North Central Forest Experiment Station, Duluth, Minnesota.

Keywords: fuelwood/ poplars, hybrid

1454. Zhong, C., D. J. Ellar, A. Bishop, S. Lin, and E. R. Hart. 2000.

Characterization of a Bacillus thuringiensis $\S$-endotoxin which is toxic to insects in three orders. Journal of Invertebrate Pathology 76:131-139.

Keywords: diseases/ insecticide

1455. Zimmerman, R. W., and S. B. Carpenter. 1980. First year coppice production from a 5-year-old black locust stand on surface mine spoil. pp. 127-129. In Symposium on Surface Mining Hydrology, Sedimentology and Reclamation. University of Kentucky, Lexington, Kentucky. Keywords: coppice/ sprouting/ locusts, black/ Robinia pseudoacacia/ hardwoods/ biomass crops/ mined land

1456. Zobel, B. J. 1981. Wood quality from fast-grown plantations. TAPPI 64:7174.

Keywords: forestry/ plantations/ short rotation woody crops/ Eucalyptus/ hardwoods/ softwoods/ mechanical properties

1457. Zobel, B. J., and R. C. Kellison. 1984. Wood: Where will it come from and where will it go? TAPPI 67:33-37.

Keywords: woody crops/ biomass resources

1458. Zsuffa, L., E. Giordana, L. D. Pryor, and R. F. Stettler. 1996. Trends in poplar culture: Some global and regional perspectives. pp. 515-544. In Biology of Populus and its Implications for Management and Conservation. R. F. Stettler, Jr. H. D. Bradshaw, P. E. Heilman, and T. M. Hinckley (eds.). NRC Research Press, Ottawa, Canada.

Keywords: conservation/ Populus/ poplars/ hybrids 


\section{DISSERTATIONS AND THESES}

1459. Allen, K. K. 1992. Effects of transgenic Populus on the biology of Plagiodera versicolora (Laicharting). M.S thesis. Iowa State University, Ames, Iowa. Keywords: Populus

1460. Bae, H. 2001. Response of plant growth and development to different light conditions in three model plant systems. Ph.D. dissertation. Iowa State University, Ames, Iowa.

Keywords: growth/ plant breeding

1461. Baertsche, S. R. 1980. The potential utilization of short-rotation biomass trees as a feed source for ruminants. Ph.D. dissertation. Michigan State University, East Lansing, Michigan. Keywords: short rotation woody crops

1462. Baker, T. R. 1983. Nursery bed density and nitrogen fertilization effects on Liquidambar styraciflua L. and Platanus occidentalis L. seedling development. M.S. thesis. University of Georgia, Athens, Georgia.

Keywords: short rotation woody crops

1463. Barker, J. R. 1981. Genetic differences between large and small Artemisia tridentata plants in contiguous populations. Ph.D. dissertation. Utah State University, Logan, Utah.

Keywords: short rotation woody crops

1464. Barrios, R. W. L. 2000. Cultivar and fertility effects on switchgrass biofuel production in southern Iowa. M.S. thesis. Iowa State University, Ames, Iowa. Keywords: cultivar/ fertility/ switchgrass/ Panicum virgatum/ biofuels/ Iowa

1465. Blum, M. R. 1978. Carbohydrate levels in sycamore coppice roots over a seven month period. M.S. thesis. University of Georgia, Athen, Georgia. Keywords: carbohydrates/ sycamore/ coppice/ roots
1466. Brejda, J. J. 1996. Evaluation of Arbuscular mycorrhiza populations for enhancing switchgrass yield and nutrient uptake. Ph.D. dissertation. University of Nebraska, Lincoln, Nebraska.

Keywords: arbuscular mycorrhiza/ switchgrass/ Panicum virgatum/ nutrient cycling/ energy crops, herbaceous/ biomass crops

1467. Bresnan, D. F. 1989. Genetic variation of silver maple (Acer saccharinum L.) provenances from several different geographic locations. M.S. thesis. Southern Illinois University, Carbondale, Illinois. Keywords: short rotation woody crops/ genetic variations/ maples, silver/ growth/ bud break/ leaf fall

1468. Brotschol, J. V. 1983. A study on some mating system parameters among three populations of Liriodendron tulipifera, using electrophoretic techniques. Ph.D. dissertation. North Carolina State University, School of Forest Resources, Raleigh, North Carolina.

Keywords: short rotation woody crops

1469. Brown, S. 1986. Sexual allocation patterns in red alder (Alnus rubra Bong) along three elevation transects. M.S. thesis. University of Washington, Seattle, Washington.

Keywords: alders/ Alnus rubra

1470. Bucciarelli, B. 1996. Wound response characteristics as related to phenylpropanoid enzyme activity and lignin deposition in resistant and susceptible Populus tremuloides inoculated with Hyposylon mammatum. Ph.D. dissertation. University of Minnesota, Crookston, Minnesota.

Keywords: enzymes/ lignin/ Populus tremuloides/ Hyposylon mammata

1471. Burk, T. E. 1981. Branch architecture and its relation to growth and 
yield of young Populus clones grown under intensive culture. Ph.D. dissertation. University of Minnesota, St. Paul, Minnesota.

Keywords: short rotation woody crops

1472. Burkot, T. R. 1978. The bionomics of the cottonwood leaf beetle on tissue cultured hybrid Aigeiros (Populus $\times$ Euramericana (Dode) Guinier) subclones. M.S. thesis. University of Wisconsin, Madison, Wisconsin.

Keywords: short rotation woody crops

1473. Campbell, M. S. F. 1983. Biomass yields of young, heavily stocked slash pine stands in north Florida. M.S. thesis. University of Florida, Gainesville, Florida. Keywords: short rotation woody crops

1474. Chen, W. 2001. Population genetics of Melampsora medusae on poplar in Minnesota, Iowa and Missouri. M.S. thesis. Iowa State University, Ames, Iowa. Keywords: populations/genetics/ Melampsora medusael poplars

1475. Chou, C-Y. 2000. Nutrient accumulation and residue decomposition of switchgrass (Panicum virgatum L. $c v$. Alamo). M.S. thesis. Texas A\&M University, College Station, Texas. Keywords: nutrients/ residues/ switchgrass/ Panicum virgatum

1476. Christopherson, J. A. 2001. Hybrid poplar plantation effects on frost depth and snow distribution on agricultural lands in northwestern Minnesota. M.S. thesis. University of Minnesota, Crookston, Minnesota.

Keywords: poplars, hybrid/ frost/ land/ Minnesota

1477. Connolly, B. J. 1981. Shrub biomass-soil relationships in Minnesota wetlands. M.S. thesis. University of Minnesota, St. Paul, Minnesota.

Keywords: short rotation woody crops
1478. Converse, T. E. 1994. Biomass yields for short rotation black locust plantations. M.S. thesis. Colorado State University, Fort Collins, Colorado. Keywords: biomass crops/ yields/ locusts, black

1479. Crawford, S. L. 1995. Small mammal diversity and abundance in hybrid poplar plantations. M.S. thesis. University of Minnesota, Duluth, Minnesota.

Keywords: mammals/ diversity/ poplars, hybrid/ Populus

1480. Cunningham, M. W. 1986. Evaluation of the potential of clonal forestry for a population of American sycamore. M.S. thesis. North Carolina State University, Raleigh, North Carolina. Keywords: short rotation woody crops/ sycamores

1481. Dunlap, J. M. 1991. Genetic variation in natural populations of Populus trichocarpa T. \& G. from four river valleys in Washington. Ph.D. dissertation. University of Washington, Seattle, Washington.

Keywords: short rotation woody crops/ growth/ morphology/ phenology/ rusts/ diseases

1482. Elmore, S. J. H. 1995. Chloroplast DNA polymorphisms in switchgrass, Panicum virgatum L. and other Panicums. Ph.D. dissertation. University of Nebraska, Lincoln, Nebraska.

Keywords: chloroplast/ DNA/ polymorphisms/ switchgrass/ Panicum virgatum

1483. Fang, Y. 1997. Effects of cottonwood leaf beetle (Coleoptera: Chrysomelidae) larval population levels on Populus terminal damage. M.S. thesis. Iowa State University, Ames, Iowa.

Keywords: cottonwoods/ leaf beetle/ Populus/ larvae/ populations

1484. Farrar, K. D. 1981. In-site stand generator for use in harvesting machine 
simulators. M.S. thesis. Virginia

Polytechnic Institute and State University, Industrial Forestry Operations Program, Blacksburg, Virginia.

Keywords: short rotation woody crops

1485. Fenn, R. C. 1987. Variation patterns in morphology and growth in F1, F2, and backcross hybrids of Populus trichocarpa T\&G and Populus deltoides Marsh. M.S. thesis. University of Washington, Seattle, Washington. Keywords: short rotation woody crops/ poplars/ breeding

1486. Figliola, A. L. 1986. Studies in the physiology, morphology, and anatomy of $P$. trichocarpa, $P$. deltoides, and their hybrids. M.S. thesis. University of Washington, Seattle, Washington.

Keywords: short rotation woody crops/ Populus deltoides/ Populus trichocarpa

1487. Frampton, Jr., L. J. 1981. Genetic variation of traits important for energy utilization in sand and slash pines. M.S. thesis. University of Florida, Gainesville, Florida.

Keywords: short rotation woody crops

1488. Gardner, W. E. 1981. Effect of tract size on the cost of reforestation. M.S. thesis. North Carolina State University, School of Forest Resources, Raleigh, North Carolina.

Keywords: short rotation woody crops

1489. Garton, S. 1990. In Vitro propagation of Salix species and the effects of macronutrition on growth, propagability and foliar nutrient accumulation in Salix stock plants. Ph.D. dissertation. University of Minnesota, St. Paul, Minnesota. Keywords: Salix/ in vitro culture/ macronutrients/ growth

1490. Gleason, A. P. 1981. The development of an infeed mechanism and strapping device for the forest residue baler. M.S. thesis. Virginia Polytechnic Institute and State University, Blacksburg, Virginia.
Keywords: short rotation woody crops/ baling/ infeed mechanism/ harvesting

1491. Gockowski, R. 1981. Financial comparison of accelerated-optimal-growth to bareroot seedlings in simulated red and jack pine pulpwood plantations in Michigan. M.S. thesis. Michigan State University, East Lansing, Michigan.

Keywords: short rotation woody crops

1492. Gold, M. A. 1984 . Honeylocust: Genetic variation and potential use as an agroforestry species. Ph.D. dissertation. Michigan State University, East Lansing, Michigan.

Keywords: short rotation woody crops

1493. Grado, S. C. 1984. An economic analysis of short-rotation Populus hybrid plantations under four commercial strategies. M.S. thesis. Pennsylvania State University, University Park, Pennsylvania. Keywords: short rotation woody crops

1494. Green, B. K. 1998. Variation in rooting potential and shoot growth of fullsib hybrid aspen. M.S. thesis. Iowa State University, Ames, Iowa.

Keywords: roots/ shoots/ aspens/ hybrids

1495. Gyenis, L. 1999. Biological control of Septoria leaf spot of hybrid poplar. Ph.D. dissertation. University of Minnesota, Crookson, Minnesota.

Keywords: Septoria/ poplars, hybrid

1496. Hall, D. S. 1991. Soil-plant root relationships of herbaceous biomass crops grown on the Piedmont of Virginia. M.S. thesis. Virginia Polytechnic Institute and State University, Blacksburg, Virginia. Keywords: roots/ soils/ energy crops, herbaceous/ Piedmont

1497. Hamlin, D. C. 1980. Spatial and temporal variability of available nitrogen in some spodic forest soils. M.S. thesis. Michigan Technological University, Houghton, Michigan.

Keywords: short rotation woody crops 
1498. Hanford, K. M. 1987. A soil resource inventory for biomass production using herbaceous crops. M.S. thesis. Cornell University, Ithaca, New York. Keywords: soil resource inventory/ biomass crops/ energy crops, herbaceous

1499. Harrell, M. O. 1980. The nutritional ecology of the cottonwood leaf beetle as influenced by hybrid clonal foliage, with notes on the insects associated with tissue-cultured hybrid poplars in Wisconsin. Ph.D. dissertation. University of Wisconsin, Madison, Wisconsin. Keywords: short rotation woody crops

1500. Herold, S. A. 1996. Genotypic variation of leaf carbon isotope discrimination and water use efficiency in hybrid Populus clones. M.S. thesis. University of Washington, Seattle, Washington.

Keywords: genotypes/ carbon/ leaf area/ water potential/ Populus/ poplars, hybrid

1501. Heuchelin, S. A. 1992. Agrobacterium mediated transformation of Populus $\times$ Euramericana 'Ogy' using the proteinase inhibitor II gene (pin2). M.S. thesis. Iowa State University, Ames, Iowa. Keywords: agrobacterium/genetic modification/ poplars, hybrid/ proteinase inhibitors/genes

1502. Hopkins, A. 1993. Genetic variation among switchgrasses for agronomic traits, forage quality, and biomass fuel production. Ph.D. dissertation. University of Nebraska, Lincoln, Nebraska.

Keywords: genetic variations/ switchgrass/ Panicum virgatum/ biomass crops/ forage crops/ fuels, biomass

1503. Howard, J. 1986. Predicting productivity for prospective upper coastal plain hardwood plantation sites as a function of chemical and physical site factors. Ph.D. dissertation. North Carolina State University, School of Forest Resources, Raleigh, North Carolina.

Keywords: short rotation woody crops
1504. Kang, H. D. 1994. Advanced biotechnological approaches and gene manipulation in Populus species. Ph.D. dissertation. Iowa State University, Ames, Iowa.

Keywords: Populus/genetic modification/ biotechnology

1505. Kennedy, J. M. 1983. Geographic variation in black locust (Robinia pseudoacacia). M.S. thesis. University of Georgia, Athens, Georgia.

Keywords: short rotation woody crops

1506. Khan, M. 1989. Rooting of American sycamore shoot cuttings for short rotation energy forestry. M.S. thesis. Mississippi State University, Mississippi State, Mississippi.

Keywords: sycamore/ cuttings/ shoots

1507. King, F. M. 1981. A method of assessing the lower limits of utilization of a conventional harvesting system performing an integrated harvest on a variety of stands. M.S. thesis. Virginia Polytechnic Institute and State University, Industrial Forestry Operations Program, Blacksburg, Virginia. Keywords: short rotation woody crops

1508. Kopp, R. F. 2000. Genetic improvement of Salix using traditional breeding and AFLP fingerprinting. Ph.D. dissertation. State University of New York, Syracuse, New York.

Keywords: genetics/ Salix

1509. Kurniadi, E. 1998. Growth and pest resistance of Populus clones grown under plantation and agroforestry conditions. M.S. thesis. Iowa State University, Ames, Iowa. Keywords: growth/ pests/ Populus/ clones/ agroforestry/ plantations

1510. Lancaster, M. W. 1991. Cultural practices to maximize seed yield of triazine tolerant near-isonuclear lines of winter rapeseed. M.S. thesis. University of Idaho, Moscow, Idaho.

Keywords: seed/ rapeseed 
1511. Lemus, R. W. 2003. Analysis of N dynamics to improve $\mathrm{N}$ use efficiency in switchgrass biomass production. Ph.D. dissertation. Virginia Polytechnical Institute, Blacksburg, Virginia. Keywords: switchgrass/ biomass feedstock production

1512. Levensen, B. 1984. Economic analysis of tree improvement research in Michigan. Ph.D. disseration. Michigan State University, East Lansing, Michigan. Keywords: short rotation woody crops

1513. Lin, S. 1997. Relationship between poplar leaf chemicals and cottonwood leaf beetle adult feeding preferences. Ph.D. dissertation. Iowa State University, Ames, Iowa.

Keywords: poplar/ leaf beetle/ cottonwoods

1514. Lindholm, L. 1979. Evaluation of soil matric potential and dawn leaf water potential as irrigation indices for hybrid Populus plantations. M.S. thesis. University of Minnesota, St. Paul, Minnesota.

Keywords: short rotation woody crops

1515. Long, R. 1982. Etiology, symptomology, epidemiology, and disease cycle of Septoria canker in Populus hybrid plantations. M.S. thesis. Pennsylvania State University, University Park, Pennsylvania. Keywords: short rotation woody crops

1516. Lu, K. 1995. Cytogenetic analyses in switchgrass (Panicum virgatum L.). M.S. thesis. University of Nebraska, Lincoln, Nebraska.

Keywords: switchgrass/ Panicum virgatum

1517. Lunden, G. L. 1983. Selected properties and char yield of wood carbonized in a nitrogen atmosphere. M.S. thesis. Pennsylvania State University, University Park, Pennsylvania. Keywords: short rotation woody crops

1518. Marco, M. A. 1987. Genetic variation among and within Eucalyptus grandis provenances in Argentina and Florida. M.S. thesis. University of Florida, Gainesville, Florida.

Keywords: short rotation woody crops

1519. Marley, D. S. 1982. An evaluation of existing and conceptual short-rotation energy plantation harvesting machines and systems. M.S. thesis. Virginia Polytechnic Institute and State University, Blacksburg, Virginia.

Keywords: short rotation woody crops

1520. Martinez-Reyna, J. M. 1995. Hybridization between Upland and Lowland and within Upland Cytotypes of Switchgrass. Ph.D. dissertation. University of Nebraska, Lincoln, Nebraska.

Keywords: hybridization/ cytotypes/ switchgrass/ Panicum virgatum

1521. Martinez-Reyna, J. M. 1998. Hybridization between Upland and Lowland and within Upland Cytotypes of Switchgrass. Ph.D. dissertation. University of Nebraska, Lincoln, Nebraska. Keywords: hybridization/ cytotypes/ switchgrass/ Panicum virgatum

1522. McCluskey, D. N. 1982 . The influence of inoculum source and fertilization on root nodule formation in Casuarina glauca. M.S. thesis. University of Florida, Gainesville, Florida.

Keywords: short rotation woody crops

1523. McKay, S. J. 1996. The Impact of River Regulation on Establishment Processes of Riparian Black Cottonwood. M.S. thesis. University of Washington, Seattle, Washington.

Keywords: regulations/ cottonwoods

1524. McKevlin, M. 1994. Effects of cultural treatments on crown architecture and tree growth in short rotation intensive culture plantations of Alnus rubra Bong. and Hybrids of Populus spp. Ph.D. dissserations. University of Washington, Seattle, Washington.

Keywords: crown architecture/ tree growth/ 
short rotation intensive culture/ short rotation intensive culture/ hybrids/ Populus/ poplars

1525. Miller, G. A. 1983. Variation in growth, nitrogen fixation, and assimilate allocation among selected Alnus glutinosa (L.) Gaertn. clones. Ph.D. dissertation. Iowa State University Press, Ames, Iowa. Keywords: short rotation woody crops

1526. Miller, R. O. 1984. Woodybiomass production in Michigan: Species, genotype, and cultural investigations. Ph.D. dissertation. Michigan State University, East Lansing, Michigan.

Keywords: short rotation woody crops

1527. Min, N. 1988. Mefluidide effects on quality and growth of perennial and annual warm-season grasses. M.S. thesis. University of Kentucky, Lexington, Kentucky.

Keywords: grasses/ mefluidide effect

1528. Molstad, N. E. 2000. Landscapes, soil morphology, and switchgrass management and productivity in the Chariton River Valley, Iowa. M.S. thesis. Iowa State University, Ames, Iowa. Keywords: landscapes/ soil properties/ switchgrass/ Chariton Valley/ Iowa/ productivity

1529. Mroz, G. D. 1982. Effects of fertilizer and site stump sprout biomass in northern hardwoods SRIC plantations. Ph.D. dissertation. Michigan Technological University, Houghton, Michigan. Keywords: fertilizer/ biomass/ hardwoods

1530. Nelson, M. 1998. Hybrid poplar plantations and small mammal diversity in the agricultural landscape. M.S. thesis. University of Minnesota, Duluth, Minnesota.

Keywords: poplars, hybrid/ diversity/ agriculture/ landscapes

1531. Onokpise, O. U. 1984. Genotype $\times$ environment interaction in European black alder (Alnus glutinosa (L.) Gaertn.). Ph.D. dissertation. Iowa State University Press, Ames, Iowa.

Keywords: short rotation woody crops

1532. Pallardy, S. G. 1978. Water relations of selected Populus clones. Ph.D. dissertation. University of Wisconsin, Madison, Wisconsin.

Keywords: short rotation woody crops

1533. Parco, A. 2000. Genome constitution and inheritance study in switchgrass (Panicum virgatum) using isozyme and DNA markers. M.S. thesis. Oklahoma State University, Stillwater, Oklahoma.

Keywords: switchgrass/ Panicum virgatum/ isozymes/ DNA

1534. Perkis, B. A. 1982. Selection of Rhizobium spp. for increased forest productivity in Michigan's upper peninsula. M.S. thesis. Michigan Technological University, Houghton, Michigan. Keywords: short rotation woody crops

1535. Perry, C. H. 1998. Hydrological impacts of short-rotation woody crop production in northwestern Minnesota. M.S. thesis. University of Minnesota.

Keywords: hydrology/ short rotation woody crops

1536. Phillips, K. J. 1982. The development and comparison of weight regressions for small size classes of red and sugar maple sprouts. M.S. thesis. Michigan Technological University, Houghton, Michigan.

Keywords: short rotation woody crops

1537. Podeszwa, C. N. 1997. Movement and population dynamics of small mammals in two hybrid poplar landscapes. M.S. thesis. University of Minnesota, Duluth, Minnesota.

Keywords: mammals/ diversity/ poplars, hybrid/ Populus/ populations 
1538. Porfirio, L-A. 2002. Soil carbon and nitrogen pools under switchgrass compared to other cropping systems. M.S. thesis. Texas A\&M University, College Station, Texas. Keywords: soil/ carbon/ nitrogen/ switchgrass

1539. Purnell, R. C. 1983. A comparison of breeding strategies for European black alder. Ph.D. dissertation. North Carolina State University, Raleigh, North Carolina. Keywords: short rotation woody crops

1540. Ramirez, H. 2002. Gain of selection and heritability on seedling vigor in switchgrass (Panicum virgatum). Ph.D. dissertation. Texas A\&M University, College Station, Texas.

Keywords: heritability/ seedlings/ switchgrass/ Panicum virgatum/ selection

1541. Reddy, K. V. 1985. Genetic improvement of Eucalyptus grandis (Hill) Maiden for coppice productivity. Ph.D. disseration. University of Florida, Gainesville, Florida.

Keywords: short rotation woody crops/ Eucalyptus grandis/genetic modification

1542. Redfearn, D. D. 1995. Relationship of developmental morphology and canopy architecture in switchgrass tiller populations to dry matter yield and fiber quality. Ph.D. dissertation. University of Nebraska, Lincoln, Nebraska.

Keywords: morphology/ canopy/ switchgrass/ fiber

1543. Reed, J. P. 1995. Factors affecting the genetic architecture of black cottonwood populations. M.S. thesis. University of Washington, Seattle, Washington. Keywords: crown architecture/ cottonwoods/ populations

1544. Reed, R. L. 1998. Switchgrass response to cadmium: Uptake and translocation. Ph.D. dissertation. Texas A\&M, College Station, Texas.
Keywords: switchgrass/ cadmium/ translocation

1545. Reichenbacker, R. R. 1994. The impact of artificial defoliation on Populus growth, biomass production and total nonstructural carbohydrate concentration. M.S. thesis. Iowa State University, Ames, Iowa. Keywords: agroforestry/ defoliation/ poplars/ biomass crops/ growth

1546. Reighard, G. L. 1984.

Physiological genetics studies of Populus grandidentata, $P$. tremuloides and their hybrid, Populus $\times$ smithii. Ph.D. dissertation. Michigan State University, East Lansing, Michigan.

Keywords: short rotation woody crops

1547. Reisinger, T. W. 1981. An evaluation of in-plant handling systems for utilization of wood residues as fuel in the South. M.S. thesis. Virginia Polytechnic Institute and State University, Blacksburg, Virginia.

Keywords: short rotation woody crops/ wood residues/ harvesting/ fuels/ handling/ transportation/ storage

1548. Reyes, I. 1983. Evaluation of leucaena forage and biofuel potential in semi-arid south Texas. M.S. thesis. Texas A\&I University, Kingsville, Texas. Keywords: short rotation woody crops/ Leucaena

1549. Rhodenbaugh, E. 1991. Water stress effects on photosynthesis and root growth in three Populus clones. M.S. thesis. University of Missouri, Columbia, Missouri. Keywords: water stress/ photosynthesis/ roots/ Populus

1550. Robison, T. L. 1984. Age-age correlations, trait correlations, and wood property variation for an Alnus glutinosa (L.) Gaertn. provenance study. Ph.D. dissertation. Iowa State University Press, Ames, Iowa.

Keywords: short rotation woody crops 
1552. Roeder, K. R. 1981. Variation in energy related traits of Eucalyptus in South Florida. M.S. thesis. University of Florida, Gainesville, Florida.

Keywords: Eucalyptus

1551. Roeder, K. R. 1988. Root starch and biomass response to season of harvesting and implication on sycamore coppice productivity and management. Ph.D. dissertation. North Carolina State University, Raleigh, North Carolina. Keywords: short rotation woody crops/ Platanus occidentalis/ coppice/ biomass crops

1553. Romero, J. E. 1987. Screening for high concentrations of erucic acid in mixed and mutated population of winter rapeseed (Brassica napus L.). M.S. thesis. University of Idaho, Moscow, Idaho. Keywords: erucic acid/ rapeseed

1554. Schultz, J. M. 1988. Erosional relations in a short-rotation Eucalyptus plantation on a typic hydrandept. M.S. thesis. University of Hawaii (Bioenergy), Honolulu, Hawaii.

Keywords: short rotation woody crops/ growth/ crop management/ soil loss/ runoff/ soil properties

1555. Schultz, Jr. E. B. 1982. Estimation of genetic parameters on half-sib families of sweetgum and sycamore. Ph.D. dissertation. North Carolina State University, School of Forest Resources, Raleigh, North Carolina. Keywords: short rotation woody crops

1556. Shen, Z. 1997. Studies on the plasticity of dormancy and on aging in switchgrass seed. Ph.D. thesis. Virginia Polytechnic Institute and State University, Blacksburg, Virginia.

Keywords: switchgrass/ seed

1557. Shen, Z-X. 1997. Switchgrass seed dormancy and after-ripening as influenced by temperature, moisture, and time. Ph.D. dissertation. Virginia Polytechnical Institute, Blacksburg, Virginia.
Keywords: switchgrass/ seeds/ temperature/ moisture content

1558. Shimizu, K. 1994. Biological control of Septoria leaf spot on hybrid poplars using Streptomyces spp. M.S. thesis. University of Minnesota, St. Paul, Minnesota.

Keywords: Septoria/ poplars, hybrid/ streptomyces

1559. Shin, M. Y. 1986. A progeny test to evaluate biomass production for intensive culture of European black alder (Alnus glutinosa (L.) Gaertn.). M.S. thesis. Iowa State University Press, Ames, Iowa. Keywords: short rotation woody crops/ alders

1560. Shirley, D. M. 1988. Herbicide studies with Populus trichocarpa (T\&G) and $P$. trichocarpa $\times P$. deltoides hybrids in the Pacific Northwest. M.S. thesis. University of Washington, Seattle, Washington.

Keywords: herbicides/ Populus trichocarpal poplars, hybrid

1561. Simonds, G. 1982. Variability of Rhizobium and Mycorrhizae on several sources of black locust. M.S. thesis. Michigan Technological University, Houghton, Michigan.

Keywords: short rotation woody crops

1562. Skovran, J. D. 1981. Determining high lead yarding forces for whole tree Appalachian hardwoods. M.S. thesis. Virginia Polytechnic Institute and State University, Industrial Forestry Operations Program, Blacksburg, Virginia.

Keywords: short rotation woody crops

1563. Slichter, T. K. 1984. Seasonal variation in nitrogen and phosphorus composition of plantation-grown American sycamore foliage. M.S. thesis. North Carolina State University, Raleigh, North Carolina.

Keywords: short rotation woody crops 
1564. Smith, J. A. 2001. Etiology of bronze leaf disease of Populus. M.S. thesis. University of Minnesota, St. Paul, Minnesota.

Keywords: etiology/ disease, bronze leaf/ Populus

1565. Tabone, T. J. 1986. Techniques in the clonal multiplication of Prosopis alba clone Bss2Vss50 through axillary bud culture. M.S. thesis. Texas A\&I University, Kingsville, Texas.

Keywords: short rotation woody crops/ Prosopis albal mesquite

1567. Tabor, G. M. 1993. Population structure of Melampsora medusae in central Iowa. M.S. thesis. Iowa State University, Ames, Iowa.

Keywords: populations/ Melampsora medusae/ Iowa

1566. Tabor, G. M. 1998 . The poplar-leaf rust pathosystem: Inheritance of resistance and pathogenic variability. Ph.D.

dissertation. Iow State University, Ames, Iowa.

Keywords: poplars/ rusts/ genes/ diseases

1568. Tain, H. 1993. Root-shoot interactions in growth: Reciprocal grafting in Populus and their F2 offspring. M.S. thesis. University of Washington, Seattle, Washington.

Keywords: root-shoot interactions/ grafting/ poplars

1569. Tharakan, P. J. 1999. Clonal performance evaluation and production physiology of willow and poplar bioenergy crops. M.S. thesis. State University of New York, Syracuse, New York.

Keywords: clonal performance/ physiology/ willows/ poplars/ biomass crops

1570. Torreano, S. J. 1986. Biomass, nutrient, and energy content of seedlings and coppice grown under short-rotation intensive culture in the southeastern United States. M.S. thesis. North Carolina State University, School of Forest Resources,
Raleigh, North Carolina.

Keywords: short rotation woody crops/ short rotation intensive culture/ site characteristics/ stand density/ crop management

1571. Van Esbroeck, G. A. 1996. Genetic control of switchgrass growth and development. Ph.D. dissertation. Texas A\&M University, College Station, Texas. Keywords: genetics/ switchgrass/ growth

1572. Ward, K. T. 1998. Molecular genetic variation in Septoria musiva and $S$. populicola. M.S. thesis. University of Minnesota, Crookston, Minnesota. Keywords: molecular genetics/ Populus

1573. Weber, J. C. 1980. Isoenzyme variation among ten populations of Populus trichocarpa (Torr. \& Gray) in the Pacific Northwest. M.S. thesis. University of Washington, Seattle, Washington.

Keywords: short rotation woody crops

1574. Wiard, B. M. 1987. Growth of selected Populus clones as affected by leaf orientation, light interception and photosynthesis. M.S. thesis. University of Washington, Seattle, Washington. Keywords: short rotation woody crops

1575. Wightman, S. J. 1987. Effects of soil fertility and foliar fertilization on biomass productivity of Prosopis spp. in south Texas. M.S. thesis. Texas A\&I University, Kingsville, Texas. Keywords: short rotation woody crops/ soil properties/ Prosopis

1576. Woo, S.-Y. 1996. Physiological differences between resistant and sensitive clones of hybrid poplar (Populus trichocarpa $\times$ Populus deltoides) to ozone exposure. Ph.D. dissertation. University of Washington, Seattle, Washington.

Keywords: physiology/ clones/ poplars, hybrid/ Populus trichocarpal Populus deltoides 
1577. Wu, R. 1995. The genetic dissection

of growth and development in Populus.

$\mathrm{Ph}$.D. dissertation. University of

Washington, Seattle, Washington.

Keywords: genetics/ growth/ Populus 
Aagaard, J. E. 654

Abrahamson, L. P. 1, 2, 3, 4, 5, 643, 644, 645, 646, 647, 649, 650, 651, 1032, 1033, 1034, 1214, 1215, 1216, 1217, 1218, 1315, 1359, 1360

Adams, D. 1328

Adegbidi, H. G. 5

Agblevor, F. A. 1381

Ager, A. 6, 7, 544

Aiken, G. E. 1122, 1123, 1124

Akinyemiju, O. A. 8, 9, 10

Alexander, R. R. 289, 290, 291

Alexandrova, K. S. 11, 12, 13

Alig, R. 1328

Allen, K. K. 637, 640, 1459

Allen, V. G. 999, 1000

Allison, L. J. 384, 385

Alstrom-Rapaport, C. 14

Anders, R. 15

Anderson, I. C. 16, 17, 435

Anderson, M. J. 750

Anderson, M. P. 25

Anderson, N. A. 97, 98, 288, 866, 868, 1126

Anliker, K. S. 122

Anselmi, N. 434

Apsley, D. K. 61, 598

Archer, S. 852

Argent, R. M. 18, 365

Ariyadasa, K. P. 19

Arnold, J. 1200

Arnold, L. E. 124, 1366

Arrillaga, I. 20

Arumuganathan, K. 569, 570, 656, 701, 1305

Arvanitis, L. G. 21

Ashby, C. A. 947

Ashby, W. C. 22, 23, 24, 87, 565, 948

Assefa, S. 25

Atkinson, W. A. 1211

Auld, D. L. 26, 27, 28, 29, 30, 31, 32, 352,

709, 708, 710, 711, 712, 713, 714, 922, 923

Avila, F. J. 637

Bae, H. 1460

Baertsche, S. R. 33, 34, 1461

Bain, R. 259

Baiyee, M. 1347, 1348
Baker, J. B. 461, 658, 657, 1114

Baker, T. R. 1462

Balasko, J. A. 894, 901, 902

Ballard, J. L. 3

Ballard, R. $675,676,768$

Banaras, M. 1067

Bandaranayake, W. E. 1232, 1233, 1236, 1237, 1239

Bangsund, D. A. 610

Barker, J. R. 736, 1293, 1463

Barnett, P. E. 35, 176

Barrios, R. W. L. 1464

Barron, W. F. 36, 911

Bartfield, B. J. 37

Bartholic, J. F. 38

Bartholomew, D. P. 787

Bassman, J. H. 228

Bauer, E. O. $779,780,776,777,778,782$, 829, 1019

Becker, D. A. 374, 384, 385, 1325, 1326

Benjamin, D. M. 101, 491, 490

Benjamin, W. H. 39

Benneman, J. 1072

Berbee, J. G. $110,491,490$

Berg, S. 1404

Bergener, M. J. 503

Berguson, W. E. 40, 41, 478, 867, 1020

Betters, D. R. 42, 158, 159, 160, 161, 162, 292, 350, 695

Bettis, B. L. 26, 27

Bevelhimer, M. S. 594

Beyea, J. 43

Bhat, M. G. 44, 45

Bhattacharya, S. 1347, 1348

Bickelhaupt, D. H. 5

Binder, B. F. 683,684

Bingaman, B. R. 46

Bingham, E. T. 1021

Bingham, L. 402, 1237

Bingham, R. L. 313, 315, 635, 1204

Biradar, D. P. 1441

Birchem, R. 47

Birr, B. A. 525

Bishop, A. 1454

Blake, T. J. 48, 49, 1251, 1246, 1252,

1247, 1248, 1249, 1250

Blanchette, R. A. 1126 
Blankenhorn, P. R. 50, 51, 52, 53, 54, 55, 56, 57, 58, 63, 64, 65, 381, 662, 804, 1129, 1164, 1169, 1171, 1172, 1168, 1170, 1175, 1174, 1176, 1173

Blinn, C. R. 658,657

Bloese, P. 59

Bluhm, D. R. 1369, 1370, 1367, 1368

Blum, M. R. 1465

Bock, B. R. 402, 718, 1232, 1233, 1234, 1236, 1237, 1238

Boerjan, W. 344, 345

Bolin, M. F. 546

Bollmark, L. 586

Bongarten, B. C. 59, 60, 61, 62, 599, 600, 609, 1200, 1201, 1202, 1203

Boring, L. R. 609

Bormann, B. T. 1211

Borse, C. B. 41

Bourgeron, P.S. 1052

Bouton, J. H. 742, 741, 1209

Bowersox, T. W. 50, 51, 52, 53, 54, 55, 56, 57, 63, 64, 65, 66, 381, 662, 693, 694, $804,1129,1169,1171,1172,1168,1170$, 1175, 1174, 1176, 1173

Bowles, J. A. 988

Boyd, S. 528

Braatne, J. H. 67, 115, 274, 530, 531

Bradley, J. 714, 990

Bradshaw, Jr., H. D. $69,70,71,68,72$, 73, 74, 75, 76, 77, 78, 79, 137, 189, 344, $345,436,564,837,838,839,845,846,847$, $1154,1155,1161,1283,1284,1302,1433$, 1432

Bransby, D. I. $80,81,82,83,84,85,400$, 401, 704, 707, 705, 706, 720, 742, 741, 743, 745, 1120, 1121, 1122, 1123, 1124, 1125

Braster, M. 260

Brejda, J. J. 86, 1306, 1466

Brendemuehl, R. H. 1042

Bresnan, D. F. 22, 23, 24, 87, 947, 1467

Breve, M. A. 1221,1222

Bridges, D. C. 30

Bridgewater, F. E. 88

Briggs, R. D. 4,5

Brissette, J. C. 446

Brooks, J. R. 532

Brooks, K. E. 1234

Brooks, K. N. 917, 919, 920

Brotschol, J. V. 1468

Brown, C. L. 47, 89, 1135, 1136, 1358

Brown, G. F. 402, 717, 718
Brown, G. N. 295

Brown, J. 990

Brown, S. 1316,1469

Brown, S. P. 616

Brummer, E. C. 91, 90, 92, 488, 538, 678, 679, 791

Bruner, M. C. 963

Brunner, A. M. 93, 94, 596, 1064, 1115 , 1182

Bryan, J. 1057

Bryant, J. P. 95, 96

Bucciarelli, B. 97, 98, 868, 1470

Buck, M. G. 99

Bullock, D. G. 714,989

Burgess, D. 428

Burk, T. E. $100,579,813,1330,1329$,

1386, 1387, 1385, 1471

Burkot, T. R. 101, 491, 490, 1472

Burns, K. F. 644, 645, 651

Burras, C. L. 92, 678, 679, 791

Butin, E. E. 750

Butler, J. 1268, 1269

Butler, J. L. 30

Buxton, D. R. 16, 17, 435, 1306

Cable, T. T. 102

Cagnon, Z. E. 621

Caha, C. A. 729

Caldas, L. S. 1137

Caldbeck, E. S. 756

Callahan, P. J. 1312

Callan, B. 842

Calvin, M. 104, 105, 103, 106, 1119 ,

1212, 1213

Campbell, M. S. F. 1473

Cannell, G. H. 301, 302, 307, 310, 311, 309

Cantor, R. A. 107

Cantrell, R. L. 108

Carkner, R. W. 524

Carlson, I. T. 548, 549, 550, 1308

Carlson, M. 7

Carman, R. C. 637

Carpenter, S. B. $1030,1065,1455$

Carter, D. R. 254, 255

Casler, M. D. 109

Castello, J. D. 110

Cermak, J. 532

Ceulemans, R. J. $\quad$ 111, 112, 113, 114, 115, 116, 117, 118, 518, 531, 532, 533, 534, 580, 581, 765, 1085, 1156

Chandler, P. 119,366 
Chang, S. 1064

Chapin III, F. S. 95

Chaput, L. J. 120

Chastagner, G. A. $839,840,841,842$,

843, 844, 938

Chen, T. H. 344, 345, 564

Chen, W. 121, 1474

Cheng, S. 245, 763

Cherney, J. H. 122, 123, 699

Chia, C. S. 1318

Chiang, S. T. 1333

Chiang, V. L. 248

Chou, C-Y. 1475

Chow, P. 124, 125

Christensen, N. B. 714

Christian, D. 547

Christian, D. C. 447, 1231

Christian, D. P. $127,128,129$

Christopher, R. 130

Christopherson, J. A. 1476

Christopherson, N. S. 131

Chum, H. H. 1382

Chun, Y. W. 132,1142

Clark III, A. 133, 134, 135, 136, 341, 343, 759, 760, 769, 799, 800, 930

Clark, P. R. 301, 302, 303, 304, 306, 305, 307, 308, 310, 311, 309

Clarke, H. R. G. 74, 137, 189

Clarke, J. F. 37

Clendenen, G. W. 138, 200, 201, 202, 207, 208

Clifton-Brown, J. C. 681

Cline, G. 139

Clum, P. 531

Coady, S. A. 289, 379

Coffman, M. S. 789

Cole, D. W. 603, 719

Cole, G. V. 289

Cole, T. G. 203, 1098

Coleman, M. D. 140, 141, 142, 143, 346,

347, 525, 621, 659, 1220

Colletti, J. P. 144, 145, 146, 377

Collins, M. 37, 148, 147

Collins, P. T. 128,129

Comai, L. 321, 323

Comer, C. W. 149, 150, 151, 251, 995, 994, 1039, 1040, 1048, 1056, 1351

Conde, L. F. 149, 152, 153, 154, 1013, 1039, 1041, 1042, 1043, 1044, 1053

Conger, B. V. $11,12,13,157,156,155$, 223, 222, 406, 407, 408, 735, 742, 741, 856,
855, 1081, 1131

Connolly, B. J. 1477

Converse, T. E. 158,1478

Cooper, L. S. 725

Copeland, L. O. 714

Cothren, J. T. 543

Couto, L. 42, 159, 160, 161, 162

Cowles, J. R. 163, 1090, 1091, 1092

Coyle, D. R. 164, 166, 165

Crabb, T. B. 167, 168, 219, 1374

Crawford, S. L. 1479

Crist, J. B. 169, 297, 359, 583, 592, 593, 805, 927, 1444

Crock, J. C. 26, 27

Crockett, R. P. 762,763

Croft, B. A. 595

Cromer, W. A. 1223

Crow, T. R. 170, 171, 172, 173, 559, 591, 984, 985, 986, 987

Cullis, C. A. 174

Cundiff, J. S. 896, 897, 1298, 1299

Cunningham, M. W. 175,1480

Curtin, D. T. $176,342,975,978,981$,

1166

Curtis, P. S. 601

Curtis, R. O. 496

Cushman, J. H. 36, 177, 178, 179, 180,

$181,182,183,185,184,655,672,702,911$, 968, 964, 966, 967, 965, 974, 1267, 1270,

1382, 1405, 1406, 1407, 1408

Dahl, J. E. 1253

Dale, V. H. 602, 721

Daly, M. J. 389, 392, 393, 395

Danfield, W. 186

Daniels, W. L. 892, 893, 895, 896, 897, 899, 900, 1389

Das, M. K. 187,188

Das, S. 906

DaSilva, F. J. K. 1223

Davis, J. M. 137, 189, 344, 345, 564

Davis, M. 1283, 1284

Davis, T. D. 190, 254, 255, 416, 417

Dawson, D. H. 191, 462, 981

Dawson, J. O. 192, 194, 193, 195, 196, 197, 297, 463

Dayton, D. C. 1111

De La Torre Ugarte, D. G. 744, 1327, 1328

de los Reyes, B. G. 25

DeBell, D. S. 198, 199, 200, 201, 202, 203, 204, 205, 206, 207, 208, 209, 211, 210, 212, 
$213,214,215,216,217,218,219,220,221$, 489, 498, 497, 544, 545, 571, 680, 903, 955, 956, 957, 958, 960, 1096, 1211, 1373, 1374. 1409, 1442

Demeter, C. 260

Denchev, P. D. 11, 12, 13, 223, 222

Deutch, S. 1381

DeValerio, J. D. 1045

DeWalle, D. R. 224, 1143

Dewey, J. 1237

Dicke, S. G. 666

Dickmann, D. I. $8,9,10,173,225,226$, 227, 228, 229, 230, 231, 232, 233, 234, 235, 236, 237, 238, 559, 591, 652, 689, 690, 691, 772, 773, 774, 849, 950, 984, 985, 986, 987, 1020, 1393

Dickson, D. 987

Dickson, R. E. $140,141,142,143,171$, 242, 240, 241, 239, 244, 243, 464, 559, 582, 621, 659, 984, 985, 986

DiCola, M. L. 54, 55, 56

DiFazio, S. P. 94, 245, 596, 763, 1178

Dillivan, K. D. 290, 291

Dimmel, D. R. 247

Dinus, R. J. 246, 247, 248, 249, 969, 1283, 1284

Dippon, D. R. 250, 251, 1039, 1040, 1047, 1046, 1048, 1049

Dixon, R. K. 487,486

Dobbins, C. L. 252

Dolan, L. S. 253

Donahue, R. A. 254, 255, 256

Doorenbos, R. 678

Doudrick, R. L. 806

Dowd, M. L. 1128

Downey, K. W. 38

Downing, M. E. 82, 92, 257, 258, 259, 260, 261, 264, 263, 262, 265, 266, 267, 268, 269, 270, 271, 272, 386, 387, 392, 393, 536, $537,594,653,655,668,830,1230,1268$, $1269,1279,1290,1315,1316$

Doyle, T. W. 672, 1410

Dripchak, K. 1089

Dubbe, D. R. 945

Duffy, M. 92, 273

Duncan, C. S. 430

Dunlap, J. M. 274, 275, 276, 277, 278, 279, 280, 531, 534, 1481

Durst, P. B. 661

Dutta Guptam, S. 735

Dzialowy, P. J. 194, 193, 197
Eaton, J. A. 762,763

Edick, S. 1316

Edwards, N. T. 1354

Edwards, R. M. 25

Egg, R. P. 1075

Ehlers, P. 814

Ehrenshaft, A. R. 281, 283, 282, 725, 970, 1406, 1407, 1411

Einspahr, D. W. 583, 927

Ek, A. R. 284, 297, 584

Ekuan, G. 513, 514, 515

Elam, C. 1283,1284

Elam, W. W. 665

Elbersen, H. W. 285, 286, 1225

Ellar, D. J. 1454

Ellingsworth, F. R. 1384

Ellis, D. D. 287

Elmore, J. L. 177

Elmore, S. J. H. 1482

Emory, W. 669

Enebak, S. A. 288

Engler, C. R. 1091,1092

English, B. C. 44, 45, 289, 290, 291, 379, 388, 389, 394, 395, 1413

Erickson, D. A. 30, 31

Erickson, D. O. 770,771

Erofeeva, S. Y. 654

Esbroeck, G. V. 632

Ettinger, T. L. 878

Etzenhouser, M. J. 292

Evans, R. 1283, 1284

Ewel, K. C. 1331

Faix, J. J. 1371

Faltonson, R. 293

Fan, L. T. 1117

Fang, Y. 294, 1483

Farnham, R. S. $355,356,552$

Farrar, K. D. 641, 853, 1484

Fege, A. S. 295, 296, 297, 933

Feirer, R. P. 247

Feldman, M. E. 403

Felker, P. 139, 300, 298, 299, 301, 302, 303, 304, 306, 305, 307, 308, 310, 311, 309, 312 , 313, 314, 315, 375, 376, 528, 635, 636, 1204, 1379

Fenn, R. C. $1157,1158,1485$

Fennell, J. A. 1381

Ferguson, K. D. 316, 698, 1062, 1063

Ferrell, J. E. 317

Fick, G. W. 318, 319, 320, 926

Figliola, A. L. 534, 1157, 1486 
Fike, W. T. 990

Fillatti, J. J. 321, 322, 323, 1022

Fillhart, R. C. 646

Finker-Templeman, L. 635

Fisher, J. T. 633

Fisher, R. F. $324,732,1043$

Fitton, R. R. 196

Flore, J. A. 227

Floyd, D. 325

Fly, J. M. 594

Fogle, D. B. 514, 515

Folger, A. G. 1071,1245

Ford III, E. C. 854,1193

Foster, G. S. 72, 1028

Frampton, Jr., L. J. 326, 1050, 1487

Francis, K. E. 1280

Franklin, E. C. 1054

Franzluebbers, A. J. 327, 328, 329, 330, 439, 440, 441

Frederick, D. J. 19, 133, 134, 135, 136, $332,331,333,334,335,336,337,338,339$, 340, 341, 342, 343, 380, 617, 626, 627, 759, 760, 768, 769, 799, 800, 801, 930, 1166, 1243,1380

Frewen, B. E. $344,345,564$

Friend, A. L. $346,347,348$

Fritschel, P. R. 818

Fritz, R. S. 349

Fu-Guang, X. 517, 516

Fulcher, R. G. 98

Funk, D. T. 195, 196

Furnier, G. 682

Furnier, G. R. 1342, 1343

Gagnon, Z. 659

Gain, W. S. 1013,1014

Gale, M. F. 800,802

Gamble, G. G. 350

Gambles, R. L. 629, 1361

Gardner, G. 682

Gardner, W. E. 333, 334, 351, 1380, 1488

Gareau, R. M. 352

Garten, Jr., C. T. $354,353,744$

Garten, C. 898

Gartner, B. L. 209

Garton, S. 355, 356, 552, 1489

Garver, E. G. 945

Geary, T. F. 149, 1051, 1052, 1351

Gebre, G. M. 357, 358, 1253, 1259, 1260

Geimer, R. L. 359

Genthner, M. H. 892, 893

George, J. R. 488, 538
Geron, C. 585

Gerstenberger, P. E. 755,869

Gertner, G. Z. 194, 193, 196

Geyer, W. A. 102, 119, 362, 363, 361, 364, 360, 365, 366, 367, 368, 369, 370, 371, $372,373,648,692,807,907,1117,1318$, $1344,1345,1409$

Gilmore, E. C. 714

Giordana, E. 1458

Girouard, P. 374

Gleason, A. P. 1490

Glumac, E. L. 375,376

Gnewikow, L. 377

Gockowski, R. 1491

Gold, M. A. 227, 1492

Goncalves, P. D. 378

Goodman, W. R. 289,379

Gordon, J. C. 293

Gordon, M. P. 74, 75, 137, 189, 436, 437, 438

Gottschalk, K. W. 228, 772

Gould, L. 372

Gower, S. T. 341,380

Graca, L. R. 161,162

Grado, S. C. 56, 381, 1169, 1171, 1172,

1168, 1170, 1175, 1174, 1176, 1173, 1493

Graham, R. L. 15, 261, 264, 263, 262,

290, 291, 382, 383, 384, 385, 386, 387, 388, 389, 390, 391, 392, 393, 394, 395, 396, 397, $398,399,557,566,721,1326,1327,1328$, 1412,1413

Grams, K. 1312

Grattapaglia, D. 73

Green, B. K. 1494

Green, J. C. 400,401

Green, T. H. 402, 717, 718, 1233, 1236, 1237, 1238

Greene, D. K. 123

Greene, J. T. 894, 901, 902

Griend, L. V. 403

Grigal, D. F. 40, 917, 918

Gronski, S. 312

Guenther, A. 585

Gullberg, U. 682

Gunderson, C. A. 1261

Gunter, L. E. 405, 404

Gupta, S. D. 406, 407, 408

Gyenis, L. 1495

Hackett, W. P. $682,868,870,878,879$

Haissig, B. E. 190, 254, 255, 321, 323,

414, 411, 410, 415, 412, 413, 409, 416, 417, 
$418,420,419,421,781,815,1021,1022$,

1113

Hall, D. O. 422

Hall, D. S. 1496

Hall, P. 423

Hall, R. B. $132,145,146,164,297,377$, 424, 426, 427, 425, 428, 429, 430, 431, 432, 433, 434, 478, 500, 501, 502, 618, 619, 620, $637,639,640,749,752,753,754,1020$,

$1141,1142,1205,1414$

Hallam, J. A. 16, 17, 435

Hames, B. 1111

Hamlin, D. C. 802, 1497

Hamm, D. 692

Hamrick, J. L. 1200, 1201, 1202, 1203

Han, K. -H. 436, 437, 438, 762

Haney, R. L. 327, 439, 440, 441

Hanford, K. M. 1498

Hang, A. N. 714, 990

Hanley, D. P. 524

Hanna, R. D. 429, 500, 502, 640, 749, 754

Hanover, J. W. 33, 34, 38, 59, 443, 442,

444, 445, 446, 1006, 1146, 1391, 1392

Hanowski, J. M. 128, 129, 447, 685, 1231

Hansen, E. A. 41, 186, 194, 193, 457, 454, 455, 460, 452, 458, 449, 450, 456, 451, 448, $459,453,461,462,463,464,465,466,467$, 468, 469, 470, 471, 473, 472, 474, 475, 476, 477, 478, 479, 481, 480, 482, 483, 484, 485, $697,737,738,739,823,826,827,824,825$, 933, 934, 1187, 1186, 1242, 1451

Hansen, P. H. 487, 486, 1257

Hanson, C. 260

Hargrove, B. 566

Harley, P. 585

Harmoney, K. R. 488, 538

Harms, W. R. 204, 205, 489

Harrell, M. O. 491, 490, 1499

Harrington, C. A. 201, 206, 207, 208, 213, 493, 495, 492, 494, 496, 498, 497, 959

Harrington, T. C. 121

Harris, R. A. 990

Harrison, R. 1300

Harry, D. E. 499

Hart, E. R. 46, 164, 166, 165, 294, 430,

500, 501, 502, 619, 637, 640, 683, 684, 750,

753, 754, 1003, 1004, 1127, 1454

Hart, J. W. 445

Hawkins, D. R. 106, 1119

Hawley, M. C. 38

Heebner, C. F. 503
Heikkinen, M. K. 352

Heilman, P. E. 6, 67, 111, 115, 116, 117 , $118,275,276,277,348,465,505,511,510$, 506, 507, 509, 508, 512, 504, 513, 514, 515, 517, 516, 518, 519, 523, 521, 522, 520, 524, 534, 1061, 1085, 1158, 1159, 1160, 1161, 1350

Hektor, B. 15

Helmig, D. 585

Hendrick, R. L. 229, 849, 950

Hendrickson, J. C. 1013, 1014

Herendeen, R. A. 197

Herms, D. A. 502, 525

Herold, S. A. 1500

Heuchelin, S. A. 526, 527, 619, 637, 640, 754, 1501

Hillebrand, J. J. 50

Hillis, W. E. 817

Hilu, K. W. 528

Hinckley, R. F. 116

Hinckley, T. M. $111,112,113,115,117$, 118, 274, 518, 529, 530, 531, 532, 533, 534, 535, 765, 924, 1011, 1059, 1085, 1086,

1087, 1088, 1102, 1100, 1103, 1101, 1104, 1161, 1297

Hines, D. J. 536, 537

Hintz, R. L. 538

Hodges, J. F. 1058

Hodges, J. W. 539

Hoffman, W. 1231

Hohenstein, W. G. 540

Hoien, E. 762

Hokans, R. H. 541

Hollick, J. B. 74

Holt, K. E. 542

Honeycutt, C. W. 327

Hons, F. M. 327, 328, 329, 330, 439, 440, 441, 543, 1082

Hook, D. D. 544, 545

Hooper, C. 546

Hopkins, A. 1502

Hopkins, A. A. 547, 548, 549, 550, 1081, 1208, 1307, 1308

Hornbeck, J. W. 603, 719

Hornicsar, C. A. 54, 56

Horwath, W. R. 551

Hosier, M. A. 355,552

Hossner, L. R. 439

Host, G. E. 553, 554, 555, 556, 557, 558, 559, 561, 560, 562, 563, 586, 985, 986,

1219,1220 
Houston, A. E. 1232, 1233, 1234, 1236, 1237, 1238, 1239

Hovermale, C. H. 990

Howard, J. 1503

Howe, G. T. 344, 345, 564, 682, 785, 1006

Huang, M. 1439

Hubbes, M. 682

Huber, D. A. 61

Huetteman, C. A. 22, 23, 24, 87, 565, 946, 947, 948, 949

Huff, D. D. 390,566

Huffman, J. B. 153, 567, 568, 1039, 1040, 1044, 1053, 1335, 1336, 1334, 1337, 1338

Hughes, E. E. 1415, 1416

Huisman, W. 681

Hultquist, S. J. 569, 570

Hunsaker, C. T. 1108

Hurd, P. D. 571

Hussey, M. A. 285, 286, 632, 1001, 1002, 1076, 1081, 1082, 1198, 1225, 1294, 1295

Huston, M. A. 572, 916

Hutchinson, J. G. 573

Immel, M. J. 1383, 1384

Impends, I. 112

Ince, P. J. 1328

Isebrands, J. G. $10,100,111,113,114$, $115,116,117,118,130,140,141,142,143$, $169,171,173,191,230,233,244,243,254$, 255, 297, 346, 347, 348, 487, 486, 525, 534, 554, 555, 556, 557, 559, 561, 560, 562, 563, 572, 578, 576, 577, 574, 575, 579, 580, 581, 582, 583, 584, 585, 586, 587, 588, 589, 590, 591, 592, 593, 621, 649, 650, 659, 772, 774, $813,816,817,917,918,927,928,929,983$, 984, 985, 986, 987, 1020, 1023, 1085, 1087. 1088, 1106, 1214, 1215, 1219, 1220, 1234, 1330, 1329, 1386, 1387, 1385, 1452

Jager, H. I. 389,395

Jakus, P. M. 594

James, R. R. 595, 596, 597, 762

Jawdy, C. M. 1239

Jech, K. 1283, 1284

Jeknic, Z. 564

Jenkins, J. 1179

Jennings, N. E. 808

Jensen, K. B. 1305

Johnsen, K. H. 598, 599, 600

Johnson, D. K. 1381

Johnson, D. W. 544, 601, 602, 603, 605, 604, 606, 719, 1254, 1296, 1300

Johnson, G. R. 608
Johnson, J. P. 1198

Johnson, K. D. 122, 123, 548, 549, 550, 1308

Johnson, K. H. 609

Johnson, M. A. 247

Johnson, R. G. 610,771

Johnson, W. C. 41,945

Johnson, W. D. 478

Johnston, C. A. 611

Johnston, J. W. 180, 181, 182, 612, 672, 1267, 1270

Jokela, J. J. 546

Jones, D. W. 613, 614, 615

Jones, R. M. 616, 803, 1077

Joslin, J. D. 402, 718, 1232, 1233, 1234, 1236, 1237, 1238

Jouanin, L. 526, 1064

Jung, H. G. 97, 1309

Jurgensen, M. F. 335, 336, 337, 338, 340, 617, 663, 799, 800, 801, 802, 1070

Kadam, K. 1130

Kaeppler, S. M. 569, 570, 656, 701

Kang, H. D. $618,619,620,1504$

Kanhouwa, S. J. 1271

Karnosky, D. F. 141, 142, 143, 621, 622, 659

Karowe, D. N. 525

Kaufmann, M. R. 390

Kean, J. N. 502

Kee, D. D. 83, 85, 720, 1125, 1199

Keeler, K. H. 43

Kellison, R. C. 334, 378, 608, 625, 623, 624, 626, 627, 628, 883, 951, 952, 1054,

1380,1457

Kelly, J. M. 603

Kennedy, J. M. 1505

Kenney, W. A. 629,630

Kerr, S. N. 631, 1143, 1144, 1145

Keyes, C. R. 209

Khan, M. 665, 1506

Kidd, G. H. 418

King, Jr., C. C. 84

King, F. M. 1507

Kiniry, J. R. 557, 632

Kinsman, J. D. 1072

Kirchner, M. J. 1009

Kirmse, R. D. 633,634

Kjelgren, R. K. 23

Kladivko, E. J. 123

Klass, S. 635,636

Kleiman, R. L. 1091,1092 
Klein, D. R. 95

Klinger, L. 585

Klopfenstein, N. B. 132, 526, 527, 637, 639, 640, 754, 1205

Kluender, R. A. 641, 1008

Knowe, S. A. 1179

Koch, P. 642

Koelling, M. R. 231

Koenig, H. 38

Kopp, R. F. 1, 3, 643, 644, 645, 646, 647, 648, 649, 650, 651, 1359, 1360, 1508

Kormanik, P. P. 1106

Korus, R. A. 29, 922, 923

Koski, V. 652

Koster, R. 1162

Kozlowski, T. T. $888,884,885,886,887$, 889

Kraft, J. M. $214,959,960$

Kratz, K. 1057

Kroll, P. 36

Kroll, T. 266, 268, 270, 653, 668

Kropp, F. 253

Kruger, E. L. 731

Krummel, J. R. 614, 615, 936

Krutovskii, K. V. 94, 654, 1115

Kszos, L. A. 655,1417

Ku, L. 656

Ku, T. T. 658,657

Kubisiak, T. L. 1205

Kucera, J. 532

Kuklewski, K. M. 51, 52

Kull, O. 659

Kuo, M. L. 660

Kurniadi, E. 1509

Kursten, E. 1072

Laag, A. E. 308

Laarman, J. G. 661

Labosky, Jr., P. 662, 1129

Lago, R. 106

Lai, Y. Z. 663, 802, 1070

Lancaster, M. W. 1510

Land, Jr., S. B. $\quad 664,665,666,1105,1210$

Landsberg, J. J. 667

Langseth, D. 265, 266, 270, 668

Lanseth, D. L. 830

Larson, G. 260, 668

Lascoux, M. 14

Lathwell, D. J. 320, 926

Lawrence, Jr., W. E. 669

Layton, P. A. 108, 630, 671, 670, 672,

970, 975, 977, 978, 1410, 1418
Lea, R. $380,626,673,674,675,676$

Ledin, S. 7, 677

Lee, C. S. 125

Lee, D. J. 569, 570, 656, 729

Lee, E. H. 621

Lee, N. 1139, 1140, 1355

Lee-Stadelmann, O. Y. 879

Lefevre, F. 1302

Lemus, R. W. 678, 679, 791, 1511

Leonardi, S. 94, 245

Lesney, M. S. 1049,1346

Lester, D. T. 680

LeTourneau, D. J. 28

Levensen, B. 1512

Levenson, J. B. $\quad 785,963$

Levine, D. A. 1108

Lewandowski, I. 681

Lewis, V. E. 96

Lichtenberg, E. 391

Liechty, H. O. 802

Lin, D. 682

Lin, S. $\quad 683,684,1454,1513$

Lindberg, J. E. $\quad 685,1231,1233$

Lindholm, L. 1514

Lindsey, C. A. 686

Lippert, D. E. 770

List, P. 1181

Littell, R. C. $1337,1339,1340$

Liu, W. 392, 393, 394, 395, 687, 688

Liu, Z. 232, 689, 690, 691

Loewen, K. H. 289

Loewer, O. J. 37

Logan, J. 1010

Long, C. E. 367, 368, 692, 1344, 1345

Long, R. 693, 694, 1515

Lord, B. E. 56

Lortz, D. A. 695

Lothner, D. C. 316, 696, 697, 698, 1062, 1063

Loucks, W. 692

Loughrey, S. 1204

Lovett, W. R. 648

Lowenberg-DeBoer, J. 252, 699

Lowerts, G. A. 700

Lu, K. 701, 1516

Lundblad, T. 265

Lunden, G. L. 1517

Lundquist, J. E. 1321

Luxmoore, R. 721

Lynch, K. L. 373

Lynd, L. R. 702, 744 
Lyons, S. 703

Ma, C. 762, 763, 1064

Ma, Z. 704, 707, 705, 706

Madgwick, H. A. I. 335, 336, 337, 338, 339, 340, 466, 467, 617

Mahler, K. A. 26, 27, 28, 29, 30, 31, 32, 709, 708, 710, 711, 712, 713, 714, 923

Majerus, K. A. 715,716

Makik, R. 1237

Malcolm, E. W. 247

Malik, R. K. 717, 718, 1233, 1239

Mann, L. K. 606, 719, 971, 1239, 1296, 1353, 1352, 1354

Manwiller, F. G. 542

Maposse, I. C. 720

Marco, M. A. 1518

Markin, G. P. 1097

Marland, G. 721, 722, 723, 724

Marland, S. 721, 722

Marley, D. S. 1519

Marquardt, P. M. 254, 255

Martin, C. W. 719

Martin, S. A. 725, 1406, 1408

Martinez, J. 637

Martinez-Reyna, J. M. 726, 727, 728, 729, 1521

Martishus, J. 186

Mask, P. L. 714, 990

Mason, P. A. 792

Masters, R. A. $1310,1311,1312$

Masterson, S. D. 1313

Matches, A. G. 999

Mathieu, S. L. 1091

Mathusa, P. D. 730

Matson, E. D. 953

Mattson, J. A. 131, 953

Mattson, W. J. 525

Mauldin, A. 1347,1348

Maxwell, D. L. 731

Maybee, C. 926

Mayes, D. A. 1236

Maynard, C. A. 649,650

Mays, D. A. 402, 717, 718, 1234, 1239

McCathy, M. C. 96

McCluskey, D. N. 732, 1522

McCown, B. H. 287, 321, 322, 323, 733, 870, 1067, 1068, 1069, 1113

McCutchan, B. G. 734

McDaniel, J. K. 735

McDonald, S. K. 843, 846, 847

McDuffie, K. E. 1098,1376
McFarland, M. J. $\quad 616,1077$

McKay, S. J. 1523

McKell, C. M. 736, 1293

McKenna, J. R. 1389

McKevlin, M. 1524

McKittrick, R. C. 1

McLaughlin, R. A. 468, 737, 738, 739

McLaughlin, S. B. $80,92,267,272,655$, 721, 740, 742, 741, 743, 744, 745, 747, 746, 1081, 1209, 1406, 1407, 1441

McLetchie, D. N. 748

McMahon, B. G. 749, 1024, 1026, 1025

McMillan, J. 1130

McMillin, J. D. 164, 166, 165, 750

McNabb, Jr., H. S. 132, 501, 526, 527, 542, 619, 637, 639, 640, 660, 751, 752, 753, $754,755,756,757,793,869,874,873,871$, 872, 881, 882, 1112, 1205, 1443

McNabb, W. A. 970, 978, 1406, 1407

McNeel, H. A. 469,1451

McRoberts, R. E. 487, 486, 758, 875

Mdafri, A. 252

Megalos, M. A. 759,760

Megraw, B. 1283, 1284

Meilan, R. 93, 761, 762, 763, 764, 790, 1064, 1178, 1180

Meinzer, F. C. 532, 765, 1440

Meldahl, R. S. 584

Melichar, L. 368

Melichar, M. W. 369

Merkle, S. A. 20, 62

Merriam, R. A. 687

Merrill, W. 694

Meskimen, G. F. 766, 767, 995, 994, 996, 1054, 1351

Messina, M. G. 341, 768, 769, 930

Meyer, D. W. 610, 770, 771

Meyer, J. 312

Michael, D. A. $173,233,559,561,560$,

587, 772, 773, 774, 984, 985, 986, 987

Michler, C. H. 254, 255, 256, 775, 779, 780, 776, 777, 778, 781, 782, 783, 870, 876

Milauskas, S. J. 784

Miller, G. A. 431, 1525

Miller, L. K. 763

Miller, R. C. 919, 920

Miller, R. O. 785, 1526

Mills, J. 1328

Min, N. 1527

Minocha, S. C. 851

Minor, H. C. 714 
Minton, N. A. 1222

Mitchell, C. P. 979

Mitchell, R. B. 998

Miyasaka, S. C. $786,787,788,1375$,

1376, 1442

Miyata, E. S. 789

Mize, C. W. $145,146,619$

Mohamed, R. 93, 790

Mohn, C. A. 1020

Moioffer, R. J. 783

Mollitor, A. V. 324

Molstad, N. E. $\quad$ 678, 679, 791, 1528

Moltzan, B. D. 792

Moon, H. K. 1141

Moore, A. 392, 393

Moore, K. J. 92, 488, 538, 548, 549, 678, 791, 997, 998, 1078, 1307, 1308

Moore, L. M. 297, 793, 794, 882, 1393

Moresco, R. F. 543

Morin, M. J. 470, 793

Morre, K. J. 550

Moser, L. E. 86, 795, 796

Mosjidis, J. A. 798, 797

Moulia, C. 349

Mroz, G. D. $663,799,800,801,802$, 1070, 1529

Mueller, C. W. 1114

Muir, J. P. 803, 1077

Murphey, W. K. 50, 53, 63, 804

Murphy, C. D. 547

Murray, M. D. 545

Myers, G. C. 805

Nagle, S. 892

Nance, W. L. 806

Nanhou, V. Y. 273

Nash, P. 301, 302

Naughton, G. G. 366, 370, 371, 372, 373, 807, 808, 937

Neale, D. 1283,1284

Nei, M. 809

Nelson, C. D. 806

Nelson, C. J. 1314

Nelson, L. E. 1114

Nelson, M. 1530

Nelson, N. D. $10,100,169,418,588,589$,

590, 772, 773, 774, 811, 812, 810, 813, 814, $815,816,817,818$

Nemethy, E. K. 106, 819

Nepal, P. 1125

Netzer, D. A. 234, 469, 471, 473, 472, 474, 475, 476, 477, 478, 479, 697, 820, 821,
$822,823,826,827,824,825,828,829,830$, 935,1027

Neuman, M. C. 949

Newcombe, G. $349,597,833,832,835$,

$836,834,831,837,838,839,840,841,842$,

$843,844,845,846,847,848,938$

Newman, D. 531

Newman, R. D. 1444

Newton, M. 21

Nguyen, P. V. 232, 236, 849, 950

Nichols, R. J. 702

Nicholson, D. P. 1347, 1348

Niemi, G. J. $128,129,447$

Niese, J. N. 850

Nima, S. 1347,1348

Noh, E. W. 851

Noon, C. E. $388,389,392,393,395$

Norby, R. J. 721, 1254, 1256, 1255, 1257

Norby, W. E. 770, 771

Nordh, N. E. 7, 433

Norton, B. E. 634

Noste, N. V. 828, 988

Nowak, C. A. 1, 4, 643, 644, 645, 646, 651, 1215, 1216, 1217, 1218, 1359, 1360

Nwoboshi, L. C. 1153

Nyangito, H. O. 45

Nyong'o, R. N. 432

Ocumpaugh, W. R. 285, 286, 632, 742,

741, 803, 852, 1001, 1002, 1076, 1081, 1082, 1198, 1225

Oderwald, R. G. $784,853,854,1192$, 1193, 1196, 1195

Odjakova, M. K. 856,855

Ojo, M. A. 44, 290, 291

Okafo, O. 446

Okazaki, E. N. 787

Oliver, C. D. 925

Oliver, G. R. 335, 336, 337, 338, 339, 340,

617

Onokpise, O. U. 431, 1531

Onstad, D. W. 319

Oregon State University $857,858,859$

Orr, D. B. 1127

Ortega, V. 1346

Osborn, J. F. 301, 302, 310, 311, 309

Ostlie, L. D. 914

Ostry, M. E. 7, 97, 98, 288, 297, 433, 478, 479, 542, 752, 755, 756, 757, 793, 794, 842, $861,865,860,864,862,863,866,867,868$, $869,870,874,873,871,872,875,876,877$, $878,879,880,881,882,890,1026,1025$, 
1066, 1126, 1341, 1342, 1343, 1393, 1443

Otegbeye, G. O. 883

Otto, K. G. 79

Otvos, J. W. 106

Overend, R. P. 259,1382

Pallardy, S. G. $888,884,885,886,887$, 889, 1532

Palmer, M. A. $\quad 890,891,1094$

Parco, A. 1533

Park, K-S. 620

Park, Y. G. 1142

Parrish, D. J. 80, 742, 741, 743, 892, 893, 894, 895, 896, 897, 898, 899, 900, 901, 902, 1081, 1298, 1299, 1388, 1389

Parsons, T. J. 74, 75

Passos, C. A. M. 162

Patterson, P. E. 666

Paul, E. A. 551

Payne, P. 248

Peabody, Jr., D. V. 519

Pedersen, J. F. 1313

Peeler, K. C. 903

Peelle, E. 904, 905

Perkis, B. A. 1534

Perlack, R. D. 36, 396, 906, 907, 910, 908, 909, 911, 912, 913, 914, 915, 916, 972, 975, 976, 980, 981, 1272, 1419

Perry, C. H. 917, 918, 919, 920, 1234, 1535

Perttu, K. 556

Perumpral, J. V. 1194

Peterson, C. L. 29, 403, 921, 922, 923

Peterson, J. M. 647

Peterson, P. R. 899, 900

Pettry, D. E. 1232, 1233, 1236, 1237, 1238, 1239

Petty, D. G. 502

Pezeshki, S. R. 924, 925

Pfeifer, R. A. 320,926

Phelps, J. E. 583, 927, 928, 929

Philippot, S. 586

Phillips, D. R. 133, 134, 135, 136, 341, 343, 759, 760, 799, 930

Phillips, K. J. 1536

Phillips, V. D. 687,688

Phipps, H. M. 234, 296, 469, 481, 480, 482, 932, 931, 933, 934, 935

Pierce, R. B. 265, 268, 269, 830

Pierce, R. S. 603

Pilate, G. 1064

Pimentel, D. 936
Pinkerton, L. R. 937

Pinon, J. 938

Podeszwa, C. N. 1537

Podila, G. K. 622

Pokorny, F. A. 939

Pope, P. E. 468, 737, 738, 739, 940, 941,

942

Porfirio, L-A. 1538

Porter, C. D. 1196,1195

Porter, J. R. 586

Porter, P. M. 714, 990

Post, W. M. 721

Prakash, C. S. 943, 944

Prasa, A. M. G. 396

Pratt, D. C. 945

Pratt, P. F. 308

Preckel, P. 252

Preece, J. E. 22, 23, 24, 87, 565, 946, 947, 948, 949

Pregitzer, K. S. 232, 235, 236, 551, 849, 950

Prine, G. M. 1055,1124

Pryor, L. D. 1458

Puello, C. H. 949

Purnell, R. C. 951, 952, 1539

Radcliffe, R. C. 953

Radwan, M. A. 207, 208, 211, 210, 212,

213, 214, 954, 955, 956, 957, 958, 959, 960

Raffa, K. 1181

Rakos, C. 15

Ramirez, H. 1540

Randolph, M. 1347, 1348

Ranney, J. W. 36, 178, 185, 184, 396, 672, 906, 910, 908, 909, 911, 912, 913, 962, 961, 963, 968, 964, 966, 967, 965, 969, 970, 971, 972, 973, 974, 975, 976, 977, 978, 979, 980, 981, 1107, 1406, 1407, 1410, 1418,

1421, 1420

Rasnake, M. 894, 901, 902

Rauscher, H. M. 171, 172, 173, 558, 559, 561, 560, 591, 982, 983, 984, 985, 986, 987

Rawanski, J. J. 988

Ray, D. E. 1327,1328

Rayburn, A. L. 1441

Raymer, P. L. 29, 30, 31, 714, 989, 990, 1221, 1222

Read, J. C. 632, 1001, 1002, 1076, 1079, 1081, 1082, 1198, 1199

Read, P. E. $355,356,552,878$

Reddy, K. V. 767, 991, 993, 992, 995, 994, 996, 1056, 1541 
Redfearn, D. D. $997,998,1542$

Reed, J. P. 1543

Reed, R. L. $\quad$ 632, 803, 999, 1000, 1001, 1002, 1076, 1077, 1079, 1080, 1081, 1082, 1544

Reichardt, P. B. 96

Reichenbacker, R. R. $1003,1004,1545$

Reighard, G. L. 1005, 1006, 1007, 1546

Reisinger, T. W. 641, 1008, 1547

Rensema, T. R. 1281

Resendez, R. 875

Reukema, D. L. 213, 215

Reyes, I. 313, 375, 376, 1204, 1548

Reynolds, J. H. 894, 901, 902, 1009, 1010

Rhodenbaugh, E. 1549

Rhodes, J. D. 139, 942

Richardson, J. R. 1331

Richter, H. 535

Ridge, C. R. 1011,1297

Riekerk, H. 151, 719, 1012, 1013, 1014, 1039

Riemenschneider, D. E. 254, 255, 321, 417, 420, 419, 421, 622, 815, 829, 830, 851, $1017,1018,1015,1016,1019,1020,1021$, 1022, 1023, 1024, 1026, 1025, 1027, 1028

Rietveld, W. J. 474, 475, 1029

Rineer, K. C. 1290

Rizy, C. G. 107

Roberts, D. A. 518,532

Roberts, D. R. 1030

Roberts, G. T. 14,1253

Roberts, P. S. 469, 1031

Robison, D. J. 2, 1032, 1033, 1034, 1214, 1215, 1217, 1218

Robison, J. R. 4

Robison, T. L. 431,1550

Rockwood, D. L. 88, 149, 150, 151, 154, 251, 326, 767, 993, 992, 995, 994, 996, 1007, 1035, 1036, 1038, 1037, 1039, 1040, 1041, 1042, 1043, 1044, 1045, 1047, 1046, 1048, 1049, 1050, 1051, 1052, 1053, 1054, 1055, 1056, 1057, 1058, 1060, 1338, 1340, 1346, 1351

Roden, J. 1059

Roeder, K. R. $1551,1552,1060$

Rogers, D. L. 1061

Rohde A. 344, 345

Rolfe, G. L. 124, 125, 546, 715, 716, 1365, 1362, 1364, 1363, 1366, 1369, 1370, 1367, 1368, 1371

Romero, J. E. 1553
Romme, W. H. 1280

Roningen, V. O. 391

Ronnberg-Wastljung, A. 7

Rood, S. B. 67

Rooney, T. 1034

Rose, D. W. 316, 698, 1062, 1063

Rose, P. A. 85

Roth, P. L. 22, 23, 24, 87, 565, 947, 948

Rothlauf, M. A. 542

Rottmann, W. H. 93, 94, 1064, 1115, 1182

Rowell, C. E. 1065

Royle, D. J. 1066

Rule, L. 145, 146

Rushton, K. 586

Russ, S. L. 1280

Russell, J. A. 1067, 1068, 1069

Russell, J. R. 488

Russell, M. 912

Sabatti, M. 434

Sain, S. 868

Saini, R. S. 1347, 1348

Sajdak, R. L. 663, 789, 799, 802, 1070

Salk, M. S. 1071

Sampson, R. N. 1072

Samson, R. 745

Sanderson, M. A. 285, 286, 616, 632, 744, 803, 999, 1000, 1001, 1002, 1074, 1073, 1075, 1076, 1077, 1078, 1079, 1080, 1081, 1082, 1083, 1084, 1225, 1227, 1294, 1295, 1381,1441

Sankhla, D. 255

Sankhla, N. 255

Saruul, P. 564

Satter, L. D. 818

Savage, T. E. 642

Scarascia-Mugnozza, G. E. 115, 348, 434, 531, 534, 1085, 1086, 1087, 1088

Scheithauer, R. 1089

Scheld, H. W. 163, 1090, 1091, 1092

Schiller, A. 685, 1093, 1231, 1235

Schipper, Jr., A. L. 890, 891, 1094, 1378, 1377

Schnable, A. 1200

Schoenholtz, S. H. 1232, 1233, 1237, 1238

Schramm, W. E. 916

Schubert, T. H. $\quad 66,168,220,221,1095$, 1096, 1097, 1098, 1099, 1373, 1374, 1376

Schuette, W. 844

Schulte, P. J. 534, 535, 1102, 1100, 1103, 
1101, 1104

Schultz, D. 145, 146

Schultz, E. B. 1105

Schultz, J. M 1554

Schultz, Jr., E. B. 1555

Schultz, R. C. 297, 377, 1004, 1106

Schumann, C. M. 1322

Schutt, J. R. 1107

Schwandt, D. L. 663

Schwartz, P. M. 1108

Scrase, J. I. 422

Scurlock, J. M. O. 681, 1072, 1110, 1109,

1111

Sederoff, R. R. 499

Seeman, S. S. 1112

Sellmer, J. C. 322, 323, 1022, 1113

Sennerby-Forsse, L. 629, 630, 677, 1409

Sernyk, J. L. 31

Serres, R. 870

Sewell, M. M. 248, 1283, 1284

Shapouri, H. 391, 1327

Shartle, S. 1194

Shaw, H. B. 1317

Shaw, K. 183, 1422

Sheehan, J. 390

Shelton, M. G. 1114

Shen, Z. 1556

Shen, Z-X. 1557

Sheppard, L. A. 93, 94, 1064, 1115, 1182

Shepperd, W. D. 390

Shi, N. Q. 640

Shimizu, K. 1558

Shin, D. 622

Shin, M. Y. 1559

Shires, M. 1237

Shirley, D. M. 1560

Shomberg, H. H. 327

Shriner, C. R. 1244

Shugart, H. H. 1107

Shultz, Jr., E. B. 1091, 1092

Sibold, K. 1116

Simonds, G. 1561

Sims, G. 84

Sims, H. G. 253

Singh, D. 687,688

Singh, S. K. 1117

Sistani, K. 402, 718

Site, J. M. 756

Sivois, D. L. 35

Skadberg, A. 145, 146

Skilling, D. D. 877, 878, 879
Skinner, J. S. $\quad$ 1064, 1115

Skinner, T. 237

Skog, K. 1328

Skolmen, R. G. 1118

Skovran, J. D. 1562

Skrukrud, C. L. $106,1119,1213$

Sladden, S. E. $81,82,83,85,720,1120$,

1121, 1122, 1123, 1124, 1125

Slattery, K. 799

Slichter, T. K. 334, 627, 1563

Slinksy, S. P. 1327, 1328

Smart, L. B. 649,650

Smith, B. 531, 534

Smith, C. T. 719

Smith, D. 313, 314, 315

Smith, J. A. 1126, 1564

Smith, M. 313

Smith, V. A. 1127

Smith, W. H. 1128

Snook, S. K. 1129

Sober, A. 659

Sokhansanj, S. 1130

Somleva, M. N. 1131

Sommer, H. E. $47,89,1132,1134,1133$, 1135, 1136, 1137, 1138, 1139, 1140, 1355, 1356, 1357, 1358

Son, S. H. 1141, 1142

Sonnelitter, R. S. 755, 756, 757

Sopper, W. E. 224, 631, 1143, 1144, 1145

Spelter, H. 1328

Sperry, J. S. 48

Stack, R. W. 792

Stadt, T. J. 1146

Stanosz, G. R. 731, 1020

Stanton, B. J. $762,844,1158$

Starner, D. E. 714,990

Steenackers, V. 1162

Steinbeck, K. 237, 1149, 1150, 1147,

1152, 1151, 1148, 1153

Steinhilb, H. M. 789

Stelzer, H. E. 1028

Stettler, R. F. $6,76,77,78,79,111,113$, $115,116,117,118,274,275,276,277,278$, $279,280,523,521,522,520,524,534,839$, 1011, 1061, 1085, 1086, 1087, 1088, 1104, $1154,1155,1156,1157,1158,1159,1160$, $1161,1162,1163,1349,1350,1433,1432$, 1435, 1434, 1437, 1436, 1438, 1458

Stevens, E. 586

Stewart, D. B. 1257

Stewart, S. 79 
Stimely, G. L. 51, 52, 54, 55, 56, 1164

Stine, M. 1140

Stinhilb, H. M. 802

Stirling, B. $845,846,847$

Stoffel, R. 265, 266, 269, 270, 668

Stokes, B. J. $\quad 342,1166$

Stokke, D. D. 660

Stone, J. M. 700

Stover, L. R. 55, 56, 65

Strand, R. F. 66, 215, 1098, 1167, 1374, 1376

Strauss, C. H. 54, 55, 56, 64, 65, 381, $1169,1171,1172,1168,1170,1175,1174$, 1176, 1173, 1177, 1409

Strauss, S. H. 93, 94, 245, 437, 438, 595, 596, 654, 762, 763, 764, 790, 1064, 1115, $1178,1179,1180,1181,1182,1224$

Strickland, R. 1183

Strine, J. 372

Stroble, S. 465

Strong, T. F. 297, 469, 850, 1184, 1185, 1187, 1186, 1188, 1453

Stroup, J. 1077

Stuart, K. W. 238

Stuart, W. B. $541,641,784,853,854$, 1189, 1190, 1191, 1192, 1193, 1194, 1196, $1195,1319,1320$

Stubblefield, G. W. 1197

Stucky, D. 252

Sturos, J. A. 592, 593, 818, 927

Stuth, J. W. 852

Sullivan, E. T. 1331

Sullivan, P. 892

Sumner, D. R. 1222

Sunderman, H. D. 990

Suplick, M. R. 1198, 1199

Surles, S. E. $1200,1201,1202,1203$

Swank, W. T. 603, 719

Switzer, G. L. 1114

Tabone, T. J. 1204, 1565

Tabor, G. M. $1112,1205,1566,1567$

Tain, H. 1568

Talbert, J. T. 88

Taliaferro, C. M. 25, 187, 188, 547, 742,

741, 1081, 1207, 1206, 1208, 1209

Tang, Z. 1210

Tarrant, R. F. 1211

Taylor, S. E. $106,1119,1212,1213$

Teclaw, R. M. 928, 929

Teissier du Cros, E. 1302

Tew, T. 343
Tharakan, P. J. $\quad 1214,1215,1216,1217$, 1218, 1569

Tharp, M. L. 566

Theseira, G. W. 557, 562, 563, 1219, 1220

Thielges, B. A. 943, 944

Thomas, D. L. 989, 1221, 1222, 1223

Thompson, D. 293

Thompson, P. B. 1224

Thornburg, R. W. 640, 754

Thornton, F. C. 402, 718, 1232, 1233, $1234,1236,1237,1238$

Thrill, D. C. 30,31

Timmins, S. P. 1108

Tinus, R. W. 1029

Tipton, P. A. 756

Tischler, C. R. 285, 286, 632, 1001, 1002, 1076, 1081, 1082, 1225, 1226, 1227

Todd, D. E. $358,605,604,606,1239$, $1254,1259,1260$

Tolbert, V. R. 402, 655, 685, 718, 744, 917, 918, 1093, 1228, 1229, 1230, 1231, $1232,1233,1234,1235,1236,1237,1238$, 1239,1240

Tolsted, D. N. $462,469,476,478,479$, 482, 483, 484, 485, 934, 1241, 1242

Tomaszewski, Z. 1131

Tombaugh, L. 38

Torreano, S. J. 1243,1570

Tower, M. 485

Toy, J. J. 1313

Trettin, C. C. $1233,1234,1238$

Trier, T. M. 525

Trimble, J. L. 185, 184, 911, 972, 973, 974, 975, 976, 981, 1244, 1245

Tritton, L. M. 719

Tsarouhas, V. 682

Tschaplinski, T. J. 48, 49, 357, 358, 721, 1251, 1246, 1252, 1247, 1248, 1249, 1250, $1253,1254,1256,1255,1257,1258,1259$, 1260,1261

Turhollow, A. F. $45,177,179,180,181$, 182, 399, 672, 723, 724, 969, 1130, 1266, 1265, 1263, 1262, 1264, 1267, 1268, 1269, $1270,1271,1272,1406,1407,1412,1413$, 1423

Turner, M. G. 1280

Turpin, T. C. 216

Tuskan, G. A. 14, 120, 248, 249, 271, 317, $358,405,404,650,655,666,682,721,748$, $806,1020,1209,1253,1258,1259,1260$, 1261, 1275, 1276, 1277, 1274, 1278, 1279, 
$1280,1281,1282,1283,1284,1285,1286$, 1321, 1322, 1406, 1407, 1424

Tyler, D. D. 1232, 1233, 1234, 1236, 1237, 1238, 1239

U. S. Department of Agriculture Forest Service 1287, 1288, 1289

Ugoretz, S. M. 1290

University of Idaho 1291

University of Kansas 1292

Van Epps, G. 736, 1293

Van Esbroeck, G. A. 1082, 1294, 1295, 1571

Van Hook, R. I. 1245, 1296

Van Lear, D. H. 603, 719

Van Miegroet, H. 603

Van Oosten, C. 848

Van Volkenburgh, E. 531, 534, 1011, 1297

Vance, C. P. 97, 98

Vasievitch, M. J. 661

Vaughan, D. H. 896, 897, 1298, 1299

Verburg, P. S. J. 1300

Verch, R. L 297, 1301

Vertessy, R. A. 1440

Vierling, L. 585

Villar, M. 79, 1302

Vines, H. M. 1358

Voelker, T. M. 782, 783

Vogel, K. P. 86, 109, 548, 549, 550, 569, 570, 656, 701, 726, 727, 728, 729, 742, 741, 795, 796, 997, 998, 1209, 1303, 1304, 1305, 1306, 1307, 1308, 1309, 1310, 1311, 1312,

1313

Voigt, P. W. 1226

Volenec, J. J. 122, 123, 1314

Volk, T. A. 3, 5, 260, 646, 647, 686, 1033, 1215, 1217, 1315, 1316, 1317

Volkenburgh, E. V. 1059

Vollmer, S. S. 1115

Voorhis, A. A. 32

Waddle, D. B. 396

Walawender, W.P. 365, 1117, 1318

Walbridge, Jr., T. A. $1194,1196,1195$, 1319, 1320

Walker, B. 1063

Walker, C. L. 1009,1010

Walla, J. A. 1321, 1322

Waller, W. 998

Walsh, M. E. 267, 272, 374, 387, 391, 397, 398, 655, 747, 746, 914, 1282, 1324, $1323,1325,1326,1327,1328$
Walsh, T. A. 1330,1329

Walters, D. T. 1306

Wampler, M. 532

Wang, C. 1322

Wang, F. C. 1331

Wang, M. 1439

Wang, S. 568, 1039, 1332, 1333, 1335, 1336, 1334, 1337, 1338, 1339, 1340

Wang, S. S. 48

Wang, Y. C. 14

Ward, C. Y. 84,85

Ward, K. T. $875,880,1341,1342,1343$, 1572

Warmund, M. R. 1344,1345

Warner, T. D. 102

Warrag, E. I. 1056, 1057, 1346

Watson, B. D. 79

Weaver, A. 1347,1348

Weber, J. C. 1349, 1350, 1573

Webley, O. J. 1351

Weir, R. J. 628

Weirman, C. 1284

Welty, L. E. 714, 990

Wenzel, C. R. 974, 975, 978, 981

West, D. C. 606, 719, 1283, 1284, 1296, 1353, 1352, 1354

Westfall, C. M. 1317

Westin, S. 233

Wetzstein, H. Y. 939, 1138, 1139, 1140, 1355, 1356, 1357, 1358

Weyers, R. E. 57, 58

Wheeler, N. 1283, 1284

Wheeler, R. 893

White, E. H. 1, 2, 3, 4, 5, 643, 644, 645, 646, 647, 651, 1032, 1033, 1034, 1215, $1315,1359,1360,1361$

White, T. A. $125,197,546,1365,1362$, 1364, 1363, 1366, 1369, 1370, 1367, 1368, 1371

Whitesell, C. D. 66, 203, 204, 217, 218, 219, 220, 221, 489, 788, 1096, 1099, 1167, 1372, 1373, 1374, 1375, 1376, 1442

Wiard, B. M. $113,115,534,581,1574$

Widin, K. D. 1378, 1377

Wiedenfeld, R. P. 543

Wieland, G. 96

Wiesman, C. 314, 315

Wightman, S. J. 1379,1575

Wilbert, S. M. 137

Williams, J. R. 632

Williams, R. A. 658,657 
Williford, M. 334,1380

Wilson, B. C. 545

Wilson, G. V. 1010

Wilson, L. F. 793, 794, 881, 882, 1393

Windsor, C. F. 1058

Winjum, J. K. 1072

Wiselogel, A. E. $\quad 745,1075,1283,1381$, 1382

Wittwer, R. F. 1383,1384

Wolf, A. T. $1386,1387,1385$

Wolf, D. D. 744, 892, 893, 894, 895, 896, 897, 898, 899, 900, 901, 902, 1081, 1083, 1084, 1388, 1389

Woo, S. -Y. 1390, 1576

Wood, B. 1391

Wood, C. W. 704, 707, 705, 706

Woods, R. F. 477, 1392, 1393

Wray, P. H. $145,146,1394$

Wright, J. 636

Wright, J. W. 446

Wright, L. L. 42, 160, 183, 185, 184, 283, 282, 317, 399, 540, 655, 667, 671, 670, 672, 677, 695, 721, 913, 914, 915, 916, 970, 972, 974, 975, 976, 977, 978, 979, 980, 981, 1072, 1177, 1240, 1279, 1285, 1286, 1395, 1397, 1396, 1400, 1402, 1398, 1401, 1399, 1403, 1404, 1405, 1406, 1407, 1408, 1409, $1410,1411,1412,1413,1414,1415,1416$, $1417,1418,1419,1421,1420,1422,1423$, 1424

Wright, N. 1425
Wu, R. 1163, 1430, 1431, 1429, 1427 , $1428,1426,1433,1432,1435,1434,1437$, 1436, 1438, 1439, 1577

Wullschleger, S. D. 354, 353, 405, 404, 742, 741, 1081, 1440, 1441

Wyatt, D. A. 990

Wyman, C. E. 702

Yeh, A. W. 788

Yokoyama, M. T. 33, 34

Yost, R. S. 1442

Young, B. A. 1001, 1002, 1227

Young, J. A. 796

Young, K. R. 1443

Zarges, R. V. 1444

Zartman, R. E. 1000

Zasada, J. C. 201, 202, 205, 207, 208

Zavitkovski, J. 191, 297, 316, 469, 698, 1031, 1062, 1188, 1449, 1445, 1450, 1446, 1447, 1448, 1451, 1452, 1453

Zhong, C. 1454

Zimmerman, D. 41

Zimmerman, P. 585

Zimmerman, R. W. 1371,1455

Zobel, B. J. 1456,1457

Zsuffa, L. 645, 651, 682, 1155, 1163, 1409, 1458

Zuberer, D. A. $328,329,330,440,441$ 


\section{APPENDIX B: KEYWORDS INDEX}

above-ground components $336,337,340$ abscisic acid 689, 1102

Acacia 1099

Acacia dealbata 335,337

Acacia melanoxylon 1098

acclimation 280

Acer 87, 947, 1124

Acer saccharinum 22, 24, 802, 948

acetyl groups 599

acetylene reduction 598

adaptation 280

admixtures 1095, 1096

aecial hosts, coniferous 843

afforestation 920

Africa 396

agricultural cooperatives 260

agricultural management practices 707

agriculture $90,257,918,1303,1530$

agrobacterium 437, 438, 527, 637, 1131,

1501

Agrobacterium tumefaciens 132, 323, 419, 1022

agroforestry $7,38,99,145,159,162,301$, $370,371,373,443,639,920,1003,1032$,

1033, 1301, 1359, 1421, 1509, 1545

Aigeiros 79

air quality 702,971

Alabama 81, 720, 1121, 1122, 1125, 1149

Albizia 203, 206, 217, 219, 221, 1096, 1099

Albizia falcataria 1098

alcohols, long-chain fatty 683

alders $6,7,96,195,196,211,210,212$, 213, 214, 215, 216, 297, 362, 378, 428, 432, 493, 495, 494, 496, 497, 503, 511, 506, 507, 504, 521, 571, 642, 903, 924, 954, 955, 959, $1211,1300,1469,1559$

alfalfa 318,319

alkane biosynthesis 1212

allelopathic effects 521

alley cropping 146

allozymes 1200,1201

Alnus 206, 216, 297, 378, 424, 430, 431, 433, 502, 544, 957, 958

Alnus glutinosa 194, 193, 195, 355, 463, 552, 1383

Alnus rubra 6, 213, 493, 495, 496, 498,
497, 503, 520, 545, 642, 680, 903, 925, 955, 956, 959, 1469

aluminum 959

amino acids 358

annuals 147,435

arabinose 122

arbuscular mycorrhiza 1466

arid lands $298,299,301,313,314,315$

aroA gene 622

arthropod 526

ash content 51, 63, 926, 969

ash, green 19,134

aspens $140,141,142,434,525,578,659$,

$868,880,1006,1280,1494$

atmosphere 532

a-tocopherylquinone 683,684

atrazine 538

atriplex 633

Auxemma oncocalyx 634

auxin 415

Bacillus thuringiensis 596

baling 1490

bamboo 1110,1111

bark percentage $134,135,136$

beans 162

beetles, ambrosia $\quad 66,1097$

beneficiation 927

benzyladenine 812,851

Betula nigra 1383

big bluestem $435,538,795$

biochemicals 819

biodiversity $129,159,850,1142,1240$

bioenergy $3,92,201,202,257,260,353$, 397, 536, 537, 647, 677, 718, 741, 744, 747, 746, 905, 1033, 1076, 1081, 1111, 1217, $1228,1326,1419$

biofuels $23,24,43,44,374,677,681,740$, 743, 899, 901, 902, 968, 977, 1072, 1120, 1125, 1274, 1388, 1406, 1407, 1414, 1464

biological control 501

biology 1028

biomass $457,653,940,1114,1529$

biomass crops $7,16,24,39,44,53,57$, $81,92,99,106,114,124,128,129,134$, $135,136,143,146,148,153,158,178,183$, 191, 200, 202, 203, 206, 207, 208, 221, 237, 246, 250, 253, 264, 263, 273, 290, 291, 297, 
$302,307,317,326,332,336,337,338,340$, 348, 364, 360, 369, 370, 383, 387, 391, 399, 402, 454, 452, 458, 450, 456, 459, 453, 461, 476, 485, 488, 501, 514, 520, 540, 543, 548, 580, 587, 589, 592, 593, 607, 612, 621, 633, $644,645,650,651,653,665,670,678,679$, 685, 688, 695, 696, 698, 720, 722, 738, 742, 769, 798, 797, 802, 819, 867, 894, 904, 905, 912, 916, 925, 930, 941, 942, 950, 962, 968, 964, 966, 971, 983, 984, 1001, 1002, 1003, 1004, 1009, 1012, 1020, 1030, 1033, 1034, 1036, 1042, 1044, 1045, 1047, 1050, 1053, 1065, 1066, 1071, 1072, 1075, 1077, 1087, 1098, 1099, 1110, 1120, 1121, 1125, 1128, $1145,1149,1150,1151,1160,1166,1167$, $1185,1187,1214,1215,1228,1230,1232$, $1238,1239,1243,1266,1265,1263,1264$, $1268,1271,1281,1282,1289,1290,1310$, $1316,1323,1325,1335,1359,1360,1361$, 1373, 1376, 1381, 1397, 1402, 1408, 1410, $1411,1415,1416,1419,1422,1445,1452$, $1455,1466,1478,1498,1502,1545,1551$, 1569

biomass energy $265,266,268,270,386$, 390, 394, 397, 422, 907, 915, 1034, 1318, $1324,1405,1452$

biomass equations 138

biomass estimates 170

biomass feedstock production 1079, 1511 biomass resources $37,38,261,290,310$, 331, 333, 334, 341, 423, 471, 611, 614, 658, 657, 770, 771, 910, 937, 1039, 1149, 1169, $1171,1172,1193,1457$

biomass, global 37

biosolids 1000

biosynthesis 247,1119

biotechnology 132, 287, 418, 421, 576, 671, 672, 733, 741, 811, 876, 968, 972,

1018, 1021, 1066, 1113, 1178, 1274, 1278, $1285,1304,1410,1504$

birds $128,129,447,685,1231,1235$,

1301, 1407

blackgum 134

bleaching 583

bole crookedness 513

border effects 448,963

boron 787

botanochemicals 1335

bottomlands 930

branch $78,100,111,116,117,118,201$, $425,589,813,1434,1438$
Brassica 28, 32, 352, 709

Brassica napus 703, 989, 1221, 1222

Brazil 42, 159, 160, 161, 634, 916

breeding $38,109,180,181,182,227,248$, 249, 287, 420, 421, 424, 432, 434, 591, 650, $672,741,749,753,766,944,968,994$, 1021, 1036, 1054, 1132, 1203, 1207, 1208, $1209,1227,1275,1273,1278,1304,1330$, 1429, 1427, 1428, 1426, 1439, 1485

bud break 22, 24, 1467, 345

bud flush 345

bud set 682

buffer strips 4,448

by-products $124,573,592,1039,1091$, 1380, 1405

cadmium 999, 1000, 1544

calcium 930, 1384

callus $47,89,222,672,879,1132,1141$, 1253,1346

calorimetry 1339,1445

Canada 374

cankers $288,868,882$

canola 990

canonical correlation 1330

canopy $532,997,1542$

carbohydrates 141, 295, 358, 412, 553, 582, 849, 1004, 1246, 1255, 1465

carbon $114,141,242,240,241,239,244$, 243, 329, 346, 347, 348, 374, 425, 534, 553, 559, 580, 582, 590, 591, 704, 707, 722, 746, $898,982,1251,1248,1255,1260,1354$,

1412, 1415, 1416, 1423, 1500, 1538

carbon dioxide $39,105,140,327,399$, 441, 487, 486, 525, 562, 563, 581, 659, 721, 722, 723, 724, 772, 773, 812, 1034, 1072,

$1255,1257,1272,1282,1413$

carbon displacement 1282

carbon sequestration $80,459,706,721$, 918, 979, 1229, 1232, 1234, 1236, 1282,

1359

carbon, soil $328,329,330,354,353,601$, 706, 1229, 1236, 1239

carnivores 127

Casuarina 149, 1014, 1338

Casuarina cunninghaminana 1053

Casuarina equisetifolia 1053

Casuarina glauca 732, 1053

cattails 945

cattle 852

cavitation 1440

cell walls 660 
cellular biology 437

cellulose $51,122,248,630,798,969$,

1283,1381

center of gravity 854

Cercidium floridium 301, 310

Chariton Valley 678, 679, 791, 1528

Chinese tallow trees 1090,1091

chitinase gene promoter 137

chloroform fumigation 441

chlorophyll 256,812

chloroplast $570,729,1482$

chromosomes 656,1141

chrysomela 165,619

Chrysomela scripta 46, 101, 164, 294, 491,

490, 683, 684, 1004

climate $37,199,364,396,457,555,562$,

563, 702, 722, 962, 979, 987, 1160, 1399

clonal orchards 473

clonal performance 1569

clonal propagation $4,22,38,52,72,74$, $89,100,115,190,234,256,275,276,277$, 293, 296, 305, 355, 410, 415, 413, 416, 417, 420, 434, 461, 465, 482, 483, 552, 565, 587, 590, 620, 665, 667, 749, 766, 767, 775, 813, 816, 828, 868, 887, 889, 932, 933, 934, 935, 946, 948, 949, 960, 986, 1025, 1057, 1085, 1113, 1134, 1136, 1140, 1156, 1187, 1186, $1210,1253,1342,1350,1385$

clonal selection $40,767,1329$

clonal variations $116,118,243,774,825$, $870,970,1210$

clones $525,621,646,651,659,764,1026$, 1214, 1509, 1576

cluster analysis 1024,1218

coal spoils $511,506,507,504$

cold hardiness $150,151,375,428,682$,

767, 903, 993, 992, 995, 1029, 1057, 1124

colonization 731

Colorado 292, 350

combustion 50, 53, 63, 200, 403, 681

commercialization $42,107,259,653,911$, 1033, 1046, 1382, 1402, 1404

community issues 390

competition $99,472,820,828$

composition $85,444,798,797,800,804$, 928, 929, 1057

composition, chemical $52,63,65,123$, $125,211,247,612,663,849,930,969$, 1039, 1091, 1122, 1124, 1270, 1333, 1383 computer tomography 1283 conifers $466,467,585,988,1182,1273$ conservation $67,265,269,518,831,1112$, 1458

Conservation Reserve Program 1326

contamination 594

conversion 667,1452

conversion technologies $50,51,114,179$, $183,246,247,250,257,290,371,568,667$, 912, 968, 1120, 1130, 1264, 1270, 1289, 1292, 1336, 1334, 1337, 1382

copper 790 coppice $23,66,99,150,197,202,212$, 251, 432, 433, 461, 498, 519, 523, 586, 633, 677, 716, 734, 757, 784, 793, 906, 928, 929, 956, 992, 995, 1051, 1056, 1147, 1153, 1159, 1218, 1243, 1252, 1247, 1281, 1351, $1395,1450,1455,1465,1551$

coproducts 1405

corn $162,538,723,724,1130,1271$

corn stover 936, 1130

cottonwoods $67,79,138,165,189,199$, 201, 202, 210, 212, 241, 239, 274, 279, 280, 292, 362, 438, 508, 518, 521, 522, 520, 581, 595, 597, 618, 619, 749, 750, 792, 924, 960, 1004, 1026, 1114, 1115, 1117, 1159, 1161, $1253,1258,1261,1301,1483,1513,1523$, 1543

cottonwoods, hybrid $590,689,762,763$,

$857,858,859$

cotyledon 20

cover crops 718

crambe 146

crop management $53,55,56,57,83,99$, 123, 149, 163, 168, 185, 184, 191, 198, 215, 266, 284, 312, 324, 432, 460, 451, 466, 467, $470,480,510,509,524,546,575,674,681$, $692,715,750,807,826,827,830,894,895$, 897, 908, 913, 942, 945, 977, 1001, 1002, 1005, 1013, 1030, 1038, 1040, 1046, 1129 , 1167, 1168, 1176, 1173, 1194, 1211, 1267 , $1288,1306,1314,1320,1365,1362,1374$, $1412,1418,1425,1554,1570$ crop production $328,1232,1303$ cropland 402 crops, lignocellulosic $44,177,180,181$, 182,1263

crown architecture $111,116,117,118$, 425, 531, 534, 587, 589, 813, 1087, 1107, $1449,1524,1543$

crown node 285, 286, 1226

Cryptosphareia 4

cultivar 1464 
cultural practices $1,9,475,477,505,706$ cuticular conductance 112

cuttings 234, 473, 1242, 1506

Cynodon 25

cytokinin $665,812,851,932,946$

cytotypes 1521

data management 384

dedicated feedstock supply systems 644 , 1405

deer 127,821

DEFICIENS 1115

defoliation 294, 597, 882, 1003, 1004, $1251,1342,1545$

deforestation 910,962

desertification 301

diesel fuels $403,921,923$

digestibility 1308

disease, bronze leaf 1126,1564

diseases $4,121,166,165,230,294,297$, 349, 378, 430, 433, 478, 597, 639, 660, 694, 750, 751, 753, 757, 811, 835, 836, 837, 838, $839,840,842,843,844,845,847,848,860$, $864,862,863,867,868,870,874,871,872$, $875,877,879,881,882,890,891,938,943$, $944,1066,1094,1112,1187,1205,1288$, 1321, 1341, 1378, 1377, 1443, 1454, 1481, 1566

diurnal pattern 1247

diversity $25,90,685,1231,1280,1479$, 1530, 1537

DNA $25,68,74,76,174,417,547,569$, 570, 656, 682, 701, 729, 811, 1305, 1482, 1533

double crops 123

Douglas-fir 1300

drainage system 544

driver issues 905

drought 232, 292, 303, 306, 307, 533, 535, 565, 690, 691, 731, 889, 1186, 1259

dry matter $85,117,335,461,667,942$

drying 669,681

ecology $67,172,518,831,1290$

economics $17,42,44,45,56,85,89,119$, $162,168,177,178,180,181,182,184,198$, 250, 251, 252, 253, 257, 264, 263, 262, 266, 267, 268, 270, 272, 273, 287, 289, 291, 297, $316,370,374,377,379,381,388,389,391$, $395,397,422,435,456,540,612,613,655$, 668, 686, 688, 696, 697, 698, 699, 744, 807, 850, 895, 897, 906, 907, 908, 909, 912, 913, 914, 915, 959, 968, 967, 965, 970, 973, 974.
$975,977,978,980,981,1062,1089,1116$, 1127, 1144, 1152, 1169, 1171, 1172, 1168, 1170, 1175, 1174, 1176, 1173, 1177, 1192, 1196, 1265, 1264, 1268, 1269, 1288, 1298, 1299, 1324, 1323, 1325, 1326, 1327, 1328, 1331, 1396, 1398, 1406, 1407, 1411, 1412, 1419,1420

ecophysiology $235,553,579,986,1214$, 1385

ecosystems 172, 244, 553, 562, 594, 1447

edge effect 963,1446

education 536

effluents 462

electricity $912,980,1289,1416$

elevation 544

elms, Siberian 292

embryogenesis $733,778,851,870,1136$, 1346

emissions $399,585,923,1272,1416$

energetics 936

energy $62,153,167,267,272,374,479$, $607,702,745,961,965,1032,1050,1143$, $1145,1233,1264,1303,1328,1367,1402$, $1417,1421,1424,1445$

energy balance $53,58,262,746,1063$, 1365

energy cane $83,1124,1265$

energy content $124,343,380,759,760$, $1062,1164,1184,1331,1452$

energy crops 146, 260, 264, 263, 262, 364, 374, 382, 384, 385, 387, 394, 397, 398, 435, 471, 478, 661, 671, 681, 686, 688, 706, 784, 807, 892, 893, 905, 961, 971, 980, 995, 1047, 1066, 1071, 1093, 1109, 1111, 1116, $1218,1228,1235,1236,1265,1267,1271$, $1272,1274,1290,1298,1315,1325,1326$, 1327, 1360, 1389, 1400, 1408, 1423

energy crops, herbaceous $16,17,80,82$, $83,84,85,146,177,179,180,181,182$, $183,252,289,317,320,382,540,655,704$, 746, 770, 771, 798, 936, 1009, 1076, 1081, $1110,1109,1111,1120,1122,1228,1230$, $1233,1265,1262,1267,1268,1270,1299$, 1389, 1401, 1403, 1406, 1407, 1466, 1496, 1498

energy, fossil 1416

Entoleuca mammata 97, 98

entomology 865

environment 390, 422, 549, 685, 904, 1235, 1278

environmental effects $43,61,174,180$, 
$181,182,183,200,262,267,272,364,386$, 387, 394, 402, 499, 512, 540, 548, 612, 673, 738, 752, 913, 917, 962, 963, 967, 965, 970, 971, 973, 974, 975, 978, 979, 980, 981,

1012, 1013, 1014, 1229, 1230, 1234, 1236, 1237, 1238, 1240, 1245, 1296, 1353, 1399, 1406, 1407, 1410, 1422

environmental risk assessment 1178

environmental sensitivity 1437

environmentalists 905

enzymes 97, 1470

enzymes, target 779

erosion $1,182,379,565,717,718,895$, 896, 897, 936, 971, 1235, 1237, 1238, 1240, 1298, 1299, 1303

erucic acid 1553

establishment 41, 162, 184, 210, 367, 368, 381, 450, 474, 475, 477, 481, 480, 483, 485, $513,821,826,827,933,953,1001,1222$, 1288, 1311, 1344, 1345, 1362, 1368, 1394 esters 923

ethanol $54,200,246,309,723,724,1130$, 1270, 1271, 1371

ethics 1181,1224

ethylene 817

etiology 1126,1564

Eucalyptus 150, 151, 154, 159, 160, 161, 162, 167, 168, 206, 217, 219, 220, 221, 324, 786, 992, 1013, 1014, 1043, 1045, 1046, 1052, 1056, 1057, 1095, 1096, 1097, 1099, 1167, 1336, 1338, 1351, 1372, 1374, 1376, 1442, 1456, 1552

Eucalyptus camaldulensis 1346

Eucalyptus globulus 1098

Eucalyptus gomphocephala 817

Eucalyptus grandis 251, 766, 767, 991, 993, 995, 994, 996, 1041, 1047, 1048, 1051, 1054, 1060, 1098, 1118, 1340, 1346, 1541

Eucalyptus macarthurii 19

Eucalyptus nitens 338

Eucalyptus regnans 335, 336, 337, 339,

617

Eucalyptus robusta 1060, 1098

Eucalyptus saligna 66, 209, 218, 340, 687, 688, 767, 787, 1118, 1373, 1442

Eucalyptus urophylla 1098

Eucalyptus viminal 19,883

Euphorbia 104

Euphorbia lathyris 1119, 1213

evaporation 1067

experimental design $88,451,448,486$,
768

expert systems 591

extractives $51,630,663,1336,1334,1381$

fallowing 474

farmers 905,1121

fatty acid composition $28,32,709$

feasibility 259

feedstocks $23,44,82,246,257,259,267$, 388, 389, 391, 394, 395, 540, 541, 612, 629, 740, 745, 759, 760, 899, 901, 907, 908, 911, 914, 915, 966, 965, 976, 1010, 1032, 1073, $1076,1082,1083,1084,1228,1238,1270$, $1274,1283,1324,1382,1400,1406,1407$, 1408, 1414, 1416

Fenusa dohrnii 430, 500, 502

fertility $1167,1243,1464$

fertilization $45,65,147,163,324,460$, $449,468,484,511,509,517,600,605,645$, 646, 651, 675, 676, 689, 690, 699, 739, 786, 787, 788, 849, 940, 942, 954, 957, 958, 971, 1002, 1030, 1058, 1125, 1198, 1255, 1347,

$1348,1359,1373,1375,1384,1442,1448$

fertilizer 1529

fescue 148

fiber $42,124,361,798,926,929,972$, $998,1288,1328,1451,1542$

field trials 763

fir 511,1273

fire management 390

fixation indices 1202

flakeboard 359

flooding $689,690,691$

floodplain 426, 1017

floral homeotic genes 761

floral meristems 1115

Florida 21, 1045, 1128, 1332

flowering $432,761,795,1182$

foliage 23,818

forage crops $91,109,156,548,632,997$,

$1010,1303,1313,1314,1502$

forest management 601,721

forest products 541,972

forest structure 606

forestry $228,245,370,417,462,510,512$, 576, 625, 627, 671, 972, 1018, 1178, 1275, 1285,1456

forests $50,53,58,69,71,73,146,161$, 191, 198, 215, 226, 426, 446, 457, 509, 529, 562, 566, 572, 585, 602, 603, 604, 617, 658, 657, 673, 751, 788, 853, 963, 1013, 1017, $1070,1143,1145,1154,1156,1165,1273$, 
1296, 1426, 1447, 1452

Fraxinus pennsylvanica 19, 1383

frequency grid 1311

frost 1476

frost 682

fructose 1251

fuel properties $18,104,702,745,1111$, $1164,1332,1338$

fuels $42,58,390,403,422,614,641,703$, 916, 922, 923, 962, 972, 1017, 1130, 1150, $1183,1271,1309,1310,1331,1335,1382$, $1416,1419,1547$

fuels, biodiesel 29,921

fuels, biomass $723,724,1502$

fuels, fossil $231,399,722,1412,1413$

fuels, liquid $29,1274,1291$

fuelwood $102,139,161,231,253,301$, 364, 366, 370, 371, 546, 808, 937, 1013, $1292,1366,1453$

fungi 349

galactose 1251

gas exchange $690,1252,1261$

gasification $38,50,1117,1318$

gender 14,748

genecology 278

genes $75,527,596,637,754,1064,1112$, $1321,1501,1566$

genetic correlations $748,992,995,1433$, 1437

genetic diversity $404,654,1197$

genetic modification $4,7,61,65,72,93$, 132, 156, 185, 184, 227, 248, 322, 323, 410, 413, 419, 499, 527, 550, 596, 623, 624, 637, 671, 670, 672, 753, 763, 775, 811, 857, 858, 859, 977, 993, 995, 1021, 1023, 1036, 1037, 1044, 1155, 1157, 1159, 1161, 1163, 1178, 1182, 1208, 1309, 1346, 1406, 1407, 1411, 1418, 1501, 1504, 1541

genetic selection 478,1218

genetic variations $6,175,275,276,277$, 280, 311, 326, 417, 523, 545, 608, 664, 666, 991, 993, 1005, 1016, 1019, 1041, 1045, 1050, 1051, 1061, 1343, 1350, 1467, 1502 genetics $14,38,62,69,70,79,88,187$, 199, 230, 236, 238, 246, 249, 279, 405, 421, 427, 436, 437, 446, 531, 549, 564, 591, 597, $628,638,649,670,680,764,785,809,833$, 839, 883, 908, 966, 972, 986, 987, 1018, $1025,1028,1131,1154,1156,1179,1182$, 1203, 1207, 1209, 1274, 1286, 1342, 1359, 1410, 1430, 1431, 1429, 1427, 1428, 1435,
$1434,1437,1436,1438,1439,1474,1508$, 1571,1577

genome size 174

genomic manipulation 1015,1162

genotypes $13,116,138,189,232,425$,

548, 549, 550, 627, 960, 1015, 1020, 1087, $1314,1437,1500$

germination $400,401,618,796,955$

germplasm $28,31,404,429,1076,1082$,

1142, 1225

girdling 761

GIS 388, 389

Gleditsia triacanthos 367,1344

global change 555,1034

Gloeophyllum trabeum 660

Glomerella cingulata 836

glucose 1251

glucosinolate 32

glyphosate $4,256,321,472,474,762$,

763,1022

government 1404

grafting $464,761,1568$

grains 543

grass seed 1312

grasses $83,147,267,272,744,745,896$, 1010, 1110, 1109, 1111, 1304, 1527

grasslands 795,1311

Great Plains 771, 907

greenhouse $445,814,946,962,979,1127$, 1179

greenhouse gases $39,396,1272$

greenwood cutting 932, 934

growing season $646,825,903$

growth $24,38,41,49,76,77,99,116$,

$139,140,152,173,199,205,210,216,225$, $250,255,318,319,361,367,442,454,452$, 496, 516, 523, 521, 525, 544, 545, 553, 581, $621,648,672,730,754,781,884,957,958$, 970, 983, 984, 985, 999, 1003, 1025, 1030, 1080, 1150, 1186, 1208, 1210, 1214, 1219, $1241,1262,1347,1433,1432,1434,1437$, 1436, 1438, 1450, 1460, 1467, 1481, 1489, $1509,1545,1554,1571,1577$

growth patterns $78,254,444,497,499$, 531, 925, 988, 1022, 1053

growth rate 209

growth responses $99,179,307,442,605$, $665,736,987,1004,1348,1391,1392$,

1393, 1442

growth retardants 761

growth, forest $563,722,1244$ 
guard cells 1103,1101

GXE interaction 550, 1051

Gymnocladus diocia 1344

habitat studies $127,128,199,1231,1240$, 1301

handling 916, 1008, 1547

hardwoods $2,4,33,34,64,133,134,135$, 178, 185, 184, 234, 271, 295, 332, 341, 343, 361, 380, 392, 393, 492, 623, 624, 627, 660, 718, 759, 760, 768, 769, 784, 799, 800, 801, $850,854,930,935,951,952,972,1093$, 1138, 1148, 1190, 1193, 1455, 1456, 1529 harvest cycles $5,519,704,734$

harvest index 544

harvesting $22,63,82,131,168,176,251$, 320, 342, 360, 416, 420, 483, 498, 524, 642, 661, 677, 681, 699, 719, 760, 849, 892, 893, 907, 908, 914, 916, 931, 1010, 1075, 1079, 1165, 1166, 1175, 1188, 1190, 1192, 1196, $1195,1198,1221,1222,1242,1268,1269$, 1288, 1298, 1306, 1351, 1352, 1354, 1389, 1490, 1547

harvesting simulation 1189,1191

Hawaii 209, 489, 687, 688, 916, 1099, 1373,1374

heating values $630,1164,1336,1334$ hemicellulose $122,248,630,798,969$, 1283,1381

herbicides $1,2,8,9,10,108,186,223$, 255, 256, 313, 314, 321, 367, 368, 419, 596, 643, 692, 762, 779, 780, 776, 777, 781, 782, $783,811,820,822,823,825,828,829$, $1018,1022,1131,1179,1344,1345,1362$, 1364, 1363, 1369, 1370, 1368, 1560

herbivores 349

heritability $188,630,993,995,994,1200$, 1207, 1206, 1437, 1540

heterogeneity 447

heterosis $91,650,1275$

hexaploid 1441

hickories 134

histochemical 98

holocellulose 51,798

honeylocusts 1200,1344

horticulture 417, 787, 1018

host-parasite specificity 845

host-pathogen 501, 1273

hybrid zones 349

hybridization $238,349,726,1163,1521$ hybrids $73,115,206,275,276,277,284$, 317, 430, 458, 482, 508, 514, 517, 516, 534,
$578,587,729,846,872,1028,1061,1085$, $1163,1253,1341,1350,1458,1494,1524$ hydraulic conductance 1440

hydrocarbons 106, 1212

hydrology 919, 920, 1440, 1535

Hyposylon mammata 1470

ideotype $227,652,1218,1426$

Illinois 565

in vitro culture $12,20,406,436,618,735$, 1142, 1489

in vitro screening 864

inbreeding 991, 993, 994

incompatibility 728

indiangrass 795

industry $386,669,1396,1404$

infeed mechanism 1490

infestation 750

infiltration 1229

inflorescences 12

information resources $281,283,282,539$, 725

input-output analysis $1172,1168,1174$

insect resistance 596, 597, 763

insecticide 1454

insects $4,75,297,378,433,500,501,502$, $683,684,750,857,858,859,882$

intensive culture $4,36,66,100,201,202$, 206, 225, 251, 458, 449, 450, 467, 667, 698, $755,756,804,816,820,821,825,828,873$, $872,881,1027,1062,1147$

intercropping 99, 162, 435

international activities 126

International Energy Agency 126

interseeding 123

introgression 349,596

Iowa 273, 791, 1394, 1464, 1528, 1567

irradiance 415

irrigation $65,224,302,358,382,452$, 462, 469, 498, 565, 645, 737, 849, 1145,

$1187,1186,1359,1445,1448$

isoprenoid biosynthesis 1212

isozymes 1202,1533

johnsongrass 83

jurema 634

Kansas 102, 363, 907

Kentucky 1065

Kentucky coffeetree 1344

kleingrass 285

Kyoto Protocol 1282

lagomorphs 127

Lake States 698, 1062 
land $21,123,252,382,613,892,893,895$, 897, 919, 964, 1144, 1298, 1389, 1412,

$1413,1423,1476$

land use 128,920

landfill leachate 130

landscapes $129,394,447,791,1528,1530$

larches 466, 820

Larix decidua 820

Larix eurolepsis 583

larvae 164, 294, 1483

latex 1119

leaf area $100,111,117,138,201,237$, $517,544,561,572,925,1223,1448,1500$

leaf beetle $164,166,165,294,595,597$, $619,683,684,763,1483,1513$

leaf blight 834,848

leaf development $47,143,232,242,241$, 544, 560, 587, 812, 1011, 1025, 1059, 1297, 1358

leaf disks 731

leaf explants 20

leaf fall $338,959,1448,1467$

leaf litter 336,959

leaf morphology 1294

leaf orientation 113, 233, 587, 1387

leaf surface chemicals 683,684

leafminer, European alders 500

leaves $23,139,587,589,621,1102,1199$, 1432

legumes 148, 221, 896, 1095, 1096

leguminous trees 192, 220, 299, 301, 303, 304, 306, 308, 1204

Leucaena 99, 301, 633, 1548

Leucaena leucocephala 313, 314, 375, 376, 1045

Leucaena pulverulenta 375

Leucaena retusa 375

life cycle analysis 422

life span 812

light $20,116,233,517,555,560,774,887$, 1031, 1087, 1449

lignin 51, 97, 122, 248, 596, 630, 798, 969, $1283,1381,1470$

linuron 472, 474

Liquidambar styraciflua 19, 47, 674, 1045, 1134, 1136, 1139, 1140, 1355, 1356, 1357

Liriodendron tulipifera 605

livestock 33,34

location theory 615

loci 837,838 locusts, black $20,59,60,61,62,158,197$, 237, 292, 368, 444, 598, 609, 802, 940, 942, 1030, 1065, 1200, 1201, 1203, 1344, 1364, $1363,1455,1478$

logistic growth curve 646

Lotus corniculatus 738

lovegrass 896

lumber $312,625,805$

macronutrients 5, 1489

magnesium 930, 1384

maltose 856

mammals $96,127,128,129,1235,1479$,

1537

manganese 1384

mannitol 856

map, linkage 1432

maples, red 134

maples, silver $24,87,144,362,360,565$, 648, 907, 948, 1467

maples, sugar 802

mapping 1432

mapping, genetic 344,345

marker-aided selection 1284

markers, genetic 248,1283

markets 257, 260, 537, 1271

Marssonina brunnea 832, 861, 873

mechanical properties 1456

mechanistic studies 1154

mechanization 1278

mefluidide effect 1527

Melaleuca 152, 154, 567, 568, 1044, 1333, 1334, 1336, 1337, 1338, 1339

Melampsora 429, 845, 847, 866, 1025, 1066, 1341

Melampsora larici-populina 840,938

Melampsora medusae 833, 839, 841, 846, 873, 943, 944, 1205, 1378, 1377, 1474, 1567

Melampsora occidentalis 792, 846

mesophyll resistance 812

mesquite $300,298,301,302,305,307$, $308,310,309,312,313,315,528,635,636$, 1204, 1565

metabolism 411

methanol 1371

Michigan 231, 446, 1146

microbial biomass $327,329,330,440$,

704

micro-cross sections 870

micronutrients 139

micropropagation $13,157,155,638$

microspectrophotometric 98 
Mimosa acutistipula 634

mined land 631, 1030, 1455

Minnesota 128, 258, 265, 268, 270, 653,

918, 919, 1476

miscanthus 681,1109

model, Thunen 613,614

modeling 555, 556, 562, 563, 586, 632

models $36,37,138,170,173,229,261$, 283, 289, 318, 319, 383, 387, 388, 389, 395, 403, 495, 553, 554, 557, 558, 561, 560, 615, 667, 688, 699, 758, 853, 982, 983, 984,

1060, 1100, 1108, 1176, 1220, 1223, 1244, 1385

models, BIOCOST 374,1325

models, ECOPHYS 118, 553, 554, 559,

561, 560, 985, 986, 1219, 1220, 1387, 1385

models, growth $577,579,584,987$

models, ORECCL 385

moisture content 1557

moisture content 58, 134, 135, 136, 339,

$666,719,1337,1340$

moisture regimes 1330

molecular biology $417,437,638,864$

molecular genetics $11,69,71,68,76,77$, 78, 247, 249, 255, 547, 650, 748, 880, 1205, $1274,1283,1302,1572$

monoculture 144,1410

morphology $8,65,99,115,348,528,531$, 652, 690, 691, 729, 997, 1074, 1073, 1078, 1083, 1084, 1085, 1273, 1329, 1343, 1350, $1356,1357,1358,1481,1542$

mortality 1185

mulch 830

multi-cropping 145,146

multiple shoots 485

multi-trait selection 1020

multivariate analysis 4

multivariate techniques 1330

mycorrhiza 1106

napiergrass 83,1124

natural gas 1371

neomycin phosphotransferase 637

Neotropical migrants 128

neutral detergent fiber 122

New York 1, 643, 1034, 1218, 1359

nitrates 599, 609, 738

nitrogen $80,146,194,193,195,196,210$, $217,219,232,242,327,328,329,330,337$, 464, 468, 484, 506, 508, 517, 516, 543, 551, 601, 602, 691, 707, 737, 798, 803, 898, 917, 926, 930, 950, 959, 1009, 1080, 1199, 1254,
1256, 1306, 1373, 1538

nitrogen fixation $139,197,198,206,221$, 303, 304, 306, 307, 475, 507, 521, 600, 802, $1065,1095,1300,1451$

nodes $12,13,155$

nodulation $304,306,507,599,732,733$

nontechnical barriers 15

North America 129, 465

North Dakota 770,1281

northcentral states $128,129,479$

no-till $1,474,477,1389$

n-primary alcohols 684

nursery, forest $24,381,473,700,793$, 1345

nutrient cycling $23,461,606,616,719$, 799, 801, 917, 1077, 1229, 1238, 1300,

1353, 1352, 1383, 1384

nutrient management $602,603,604,715$, 788, 824, 954, 1466

nutrient use efficiency 5

nutrients $63,95,139,335,336,337,338$, 340, 343, 356, 376, 464, 512, 522, 543, 617, 632, 676, 768, 769, 940, 956, 959, 1014,

$1114,1354,1375,1475$

nutrients, filter strip 1077

nutrition 38,930

oaks 134, 604, 606

oil 105,1452

oils, vegetable $921,922,1291$

oilseeds $177,180,181,182,989,1089$,

1091, 1267

Olney tesota 301, 304, 310

ontogeny 407

operational considerations 206, 1418

organic matter 506

organic solute accumulation 1250

organogenesis 20

osmotic adjustment $357,358,1257,1258$, 1261

osmotic potential $358,924,1067,1260$

outcrossing rates 1202

ozone $140,142,525,562,563,621,622$, 659, 1390

Pacific Northwest 1291

Panicum virgatum 11, 12, 13, 80, 81, 82, 83, 86, 92, 146, 148, 147, 187, 188, 223,

222, 257, 267, 272, 273, 285, 286, 291, 354, $353,379,384,385,388,391,394,398,400$, 401, 404, 406, 407, 408, 435, 538, 547, 548, 549, 550, 569, 570, 656, 699, 701, 704, 707, 705, 706, 720, 726, 727, 729, 735, 740, 742, 
$741,745,747,746,795,796,852,856,855$, 894, 896, 898, 899, 900, 901, 902, 997, 998, 1001, 1002, 1009, 1010, 1073, 1075, 1076, 1077, 1078, 1079, 1080, 1081, 1083, 1084, $1121,1122,1123,1125,1198,1199,1206$, $1208,1209,1225,1238,1265,1272,1307$, $1309,1310,1324,1323,1381,1388,1441$, $1464,1466,1475,1482,1502,1516,1521$, 1533,1540

paper $542,662,1129,1444$

parasites $349,752,882$

Parkinsonia aculeata 301, 310

pasture 488,1311

pathogens $75,349,526,793,831,864$,

862, 1342

Pau Branco 634

peat 787

Pennisetum 1124

perennials $272,435,575,740,743,745$, 896, 1093, 1123, 1305

Peridermium harknessii 1322

Pestalotiopsis populi-nigrae 835

pesticides 45,166

pests $38,95,96,101,491,490,500,637$,

640, 753, 755, 756, 763, 794, 824, 857, 858,

859, 865, 971, 1066, 1097, 1393, 1509

pH 139, 1000

phenolic glycosides 46,683

phenology $24,78,115,201,502,590,750$,

1024, 1025, 1085, 1156, 1329, 1350, 1481

phenotype $187,666,1025,1141$

Phillipines 916

phosphorus $139,543,803,917,930,958$, 1373

photosynthesis $8,113,114,141,143,171$, 232, 233, 236, 244, 254, 255, 256, 274, 411, 487, 534, 554, 558, 559, 561, 587, 588, 589, 590, 591, 659, 667, 689, 772, 773, 812, 810, 814, 816, 950, 986, 1086, 1247, 1248, 1249, $1255,1386,1387,1385,1426,1441,1449$, 1448, 1452, 1549

phylogeny 189

physiology $8,115,142,225,226,228$, 236, 297, 518, 531, 564, 591, 640, 652, 671, 741, 895, 897, 1029, 1085, 1156, 1157, 1259, 1329, 1411, 1569, 1576

phytohormones 761

phytoremediation 1276,1277

phytotoxic effects 643

Piedmont 1496

pines $19,154,204,250,326,414,415$,
$412,466,628,657,675,676,815,851,939$, $1007,1014,1031,1035,1043,1050,1058$, 1194, 1283, 1284, 1321, 1338

pinesgrowth responses 1005

Pinus 161, 627, 628

Pinus banksiana 1445

Pinus clausa 1007, 1042, 1050, 1054

Pinus elliottii 99, 250, 1007, 1047, 1050, 1054, 1140

Pinus palustris 1054, 1140

Pinus ponderosa 1321, 1322

Pinus radiata 99, 335, 337, 617

Pinus resinosa 851

Pinus taeda 489, 605, 604, 1054

Pinus virginiana 1054

Plagiodera versicolara 637

plant age 65

plant breeding 92,1460

plant characteristics 543

plant density 1080,1311

plantations $38,100,119,154,158,160$, 162, 202, 234, 284, 292, 316, 331, 366, 372, $373,455,449,462,476,500,557,578,613$, $615,785,808,822,826,827,828,906,907$, 1210, 1359, 1360, 1374, 1380, 1456, 1509

planting density $5,150,205,213,224$, 250, 251, 730, 907, 977, 1044, 1047, 1052, 1409

plastic mulch 565

Platanus 461

Platanus occidentalis $19,89,175,237$, 665, 1045, 1105, 1210, 1243, 1383, 1384, 1551

ploidy level 1441

plot size 448

policy $15,379,1417$

pollution $141,143,962$

polymers, liquid 931

polymorphisms 1482

poplar 1513

poplar, yellow 134

poplars $4,7,9,40,46,48,52,56,74,75$, 77, 78, 89, 94, 100, 115, 116, 137, 169, 171, 173, 200, 201, 202, 206, 225, 229, 232, 233, 234, 236, 238, 240, 241, 274, 275, 276, 277, $278,293,295,296,317,321,322,323,362$, 381, 385, 394, 409, 424, 425, 433, 434, 448, $450,451,452,461,462,468,469,473,472$, $475,477,482,501,513,515,517,519,524$, $553,554,557,558,559,561,563,573,574$, 575, 577, 578, 581, 587, 589, 590, 591, 593, 
$618,630,637,639,652,667,689,693,695$, 698, 731, 737, 738, 739, 749, 772, 773, 774, $777,778,792,794,811,812,813,814,815$, $816,818,824,827,828,829,834,840,843$, $845,848,860,864,862,863,872,874,875$, $876,880,881,882,887,889,890,891,928$, 931, 933, 935, 938, 950, 970, 983, 984, 985, 986, 987, 1003, 1023, 1025, 1028, 1059, 1061, 1062, 1064, 1066, 1068, 1069, 1085, 1094, 1101, 1102, 1103, 1104, 1127, 1129, $1134,1141,1158,1159,1162,1163,1170$, $1174,1175,1177,1187,1188,1214,1219$, $1220,1260,1272,1281,1283,1286,1287$, 1297, 1301, 1302, 1341, 1342, 1350, 1382, 1383, 1385, 1387, 1390, 1392, 1418, 1427, $1428,1434,1436,1437,1438,1439,1443$, $1446,1448,1458,1474,1485,1524,1545$, 1566, 1568, 1569

poplars, hybrid $1,4,41,51,54,63,64$, $69,76,110,117,127,128,129,130,138$, 146, 164, 186, 205, 207, 208, 224, 228, 230, 232, 254, 255, 256, 258, 266, 269, 271, 297 , 316, 348, 359, 392, 393, 398, 419, 436, 447, $454,455,458,459,460,465,469,474,476$, 478, 480, 484, 485, 527, 532, 596, 640, 653, 662, 668, 682, 689, 690, 691, 694, 698, 730, 753, 754, 764, 765, 774, 780, 781, 782, 783, $804,816,818,821,822,825,826,832,835$, $837,838,839,841,844,861,867,868,869$, $870,917,919,929,932,933,1022,1027$, 1031, 1088, 1093, 1106, 1145, 1165, 1176, $1179,1215,1218,1238,1242,1246,1251$, $1249,1250,1252,1258,1259,1261,1265$, 1284, 1323, 1329, 1342, 1359, 1377, 1378, 1393, 1449, 1450, 1453, 1476, 1479, 1495, 1500, 1501, 1530, 1537, 1558, 1560, 1576

poplars, short rotation 246

populations $809,1026,1308,1474,1483$, 1537, 1543, 1567

Populus 8, 10, 48, 55, 65, 67, 68, 69, 70, $71,98,101,111,113,118,121,127,128$, 132, 138, 164, 166, 165, 193, 194, 207, 208, 236, 238, 271, 279, 294, 344, 345, 349, 358, 392, 393, 429, 437, 438, 463, 464, 481, 483, 490, 515, 518, 525, 526, 534, 542, 555, 562, 564, 580, 584, 588, 592, 596, 597, 619, 621, 622, 637, 638, 646, 659, 671, 683, 684, 748, 750, 751, 755, 756, 757, 762, 764, 776, 779, 780, 790, 830, 831, 835, 836, 847, 871, 878, $880,884,885,886,888,934,1004,1020$, 1024, 1025, 1064, 1087, 1093, 1113, 1126,
$1142,1163,1168,1173,1178,1179,1180$, $1181,1182,1184,1186,1238,1241,1252$, $1253,1259,1275,1278,1279,1282,1330$, 1390, 1427, 1428, 1433, 1432, 1435, 1437, $1439,1444,1445,1458,1459,1479,1483$, $1500,1504,1509,1524,1537,1549,1564$, 1572, 1577

Populus deltoides 112, 239, 514, 516, 587, 660, 817, 943, 944, 1011, 1158, 1160, 1205,

1247, 1249, 1258, 1261, 1486, 1576

Populus Euramericana 101, 491, 590, 620

Populus grandidentata 1006

Populus maximowiczii 1247

Populus nigra 1247, 1249

Populus tremuloides 97, 141, 143, 288, 1006, 1470

Populus trichocarpa 77, 112, 274, 276, 277, 280, 498, 513, 514, 516, 523, 587, 792, $842,925,956,960,1011,1016,1019,1026$, 1102, 1103, 1157, 1158, 1160, 1258, 1261, 1349, 1486, 1560, 1576

Populus tristis 284, 589, 590, 805, 927, 1448

potassium $358,464,930,1384$

power generation $50,200,607,916$

prairies 570,751

prediction equations 1060,1098

pretreatments $200,481,636$

processing 200, 541

production $148,215,257,262,267,317$, 377, 512, 695, 912, 913, 915, 1071, 1116, 1122, 1144, 1166, 1222, 1259, 1402

production systems $131,297,652,1055$, 1063, 1401

productivity $111,118,120,133,176,206$, 227, 315, 320, 375, 376, 392, 393, 425, 457, 454, 517, 516, 519, 581, 611, 679, 681, 760, 791, 799, 945, 964, 970, 971, 977, 1004, 1036, 1037, 1044, 1061, 1090, 1111, 1214, 1353, 1410, 1414, 1450, 1528

progeny tests $59,108,1035,1054$

propagation $202,249,297,356,414,411$, 515, 635, 636, 1134, 1137, 1275

Prosopis 300, 301, 302, 303, 305, 306, 307, 308, 309, 310, 311, 312, 528, 633, 1379, 1575

Prosopis alba 139, 313, 314, 315, 635, 636, 1204, 1565

Prosopis glandulosa 139

proteinase inhibitors $74,526,527,637$, 1501 
provenance trials $22,23,24,680,947$, 993, 1054

pulp, kraft $574,583,593,927$

pulpwood 215, 662, 1013, 1017, 1129, 1444

pyrolysis 38

pyrolysis molecular beam mass

spectrometry 1283

quality $54,248,630,681,927,939,969$, 1037,1240

quantitative trait loci (QTL) 69, 73, 344,

$345,1283,1431,1433,1432$

quantum sensors 1449

Quercus phellos 19

radiation, solar 587, 667, 985, 1371, 1449

radioimmunoassays 689

radionuclides 1276,1277

rainfall $232,318,319$

rangeland $303,1293,1311$

RAPD markers 14,1280

rapeseed $26,27,29,30,31,325,703,708$, 710, 711, 712, 713, 714, 923, 989, 990,

$1089,1221,1222,1510,1553$

reclamation $506,507,504$

reducing sugar 415,412

reforestation 1379

regeneration $157,223,222,407,408,499$, 733, 933, 1054, 1068, 1353

regional analysis $44,87,179,290,291$, 909, 964, 965

regression analysis $158,320,758$

regulations 1271,1523

rejuventaiton 1247

remediation 594

renewable energy $44,105,103,106,107$, $317,331,333,351,372,373,744,1341$, 1400

reproduction $199,596,1182$

residues $328,606,642,669,905,941$, 1008, 1195, 1228, 1269, 1319, 1405, 1475

resource assessment $291,310,385,388$, 389, 395, 614, 655, 1008, 1169, 1171, 1172, 1324

resources 291, 941, 1320

respiration 140,591

restoration $278,390,511$

riparian buffer strips 1266

risk 107, 906

Robinia pseudoacacia 20, 60, 197, 237, 368, 444, 599, 600, 609, 802, 1030, 1065, $1203,1344,1455$ roots $1465,1494,1496,1549$

roots $47,89,99,140,142,175,190,229$, 235, 346, 347, 348, 410, 411, 412, 414, 415, 416, 417, 436, 464, 482, 514, 515, 599, 665, 705, 870, 898, 924, 931, 934, 950, 1015, $1016,1019,1156,1210,1219,1220,1246$, 1249, 1260, 1356

root-shoot interactions 982,1568

rootstock 23,1153

rotation length $52,64,65,100,213,250$,

$370,425,977,1153$

Roundup 763

row spacing 704, 707, 803

runoff $1229,1237,1240,1554$

rust resistance 1302

rusts $121,792,824,833,840,841,843$, 844, 845, 847, 866, 938, 943, 944, 1025, $1066,1205,1378,1377,1481,1566$

rye 146

sagebrush 736

Salicaceae 1317, 1432

salicortin 683

salinity 308,1213

Salix 5, 40, 41, 79, 89, 356, 424, 433, 556, 586, 643, 644, 645, 646, 649, 650, 651, 652, 1360, 1489, 1508

Salix viminalis 14

Salmonella typhimerium 321, 1022

sandhills 1042

sap flow 1440

Sapium sebiferum 163, 1045, 1092

scale $397,566,1230$

scaling 557,1440

scanning electron microscopy 583,660 ,

927,1357

screening 430

seed $286,400,401,405,428,627,628$, $648,727,852,955,1146,1365,1367,1510$, 1556

seed dormancy 1227

seedlings $38,66,400,401,406,407,600$, 608, 609, 621, 716, 817, 820, 903, 996, 1006, 1030, 1133, 1280, 1311, 1365, 1433, 1540

seeds 1557

segregant analysis 1205

segregation distortion 77

selection $325,664,708,710,711,712$, 713, 714, 1023, 1105, 1246, 1287, 1330, 1540

self-thinning 204 
semi-arid $299,303,306,307,313,314$, 315

senescence $112,195,196,812,924,1247$

Septoria 4, 542, 693, 756, 842, 861, 869, 874, 891, 1025, 1066, 1495, 1558

Septoria musiva 694, 731, 755, 793, 861, 873, 875, 878, 881, 1342, 1343

Septoria populicola 837,838

Sericea lespedeza 83, 798, 797

shelterbelts 120

shoot pruning 1252

shoots $47,243,346,347,406,436,590$, 618, 735, 946, 1156, 1204, 1247, 1249,

1494, 1506

short rotation intensive culture $5,10,41$, 100, 131, 144, 169, 176, 185, 184, 236, 278, 284, 297, 359, 454, 455, 469, 474, 475, 478, 485, 514, 559, 574, 592, 629, 633, 644, 696, 697, 805, 813, 818, 826, 827, 906, 907, 908, 909, 911, 927, 953, 966, 977, 1047, 1167, 1218, 1242, 1409, 1420, 1524, 1570 short rotation woody crops $23,35,36$, $40,42,49,61,64,115,126,128,154,158$, 164, 178, 202, 207, 208, 215, 227, 235, 251, 261, 271, 281, 283, 282, 292, 294, 297, 300, $317,350,363,361,364,360,369,370,382$, $384,392,393,399,455,458,449,450,453$, 462, 466, 467, 470, 473, 476, 479, 500, 508, 517, 516, 539, 540, 554, 556, 557, 579, 586, $589,593,629,631,670,685,687,695,697$, 717, 752, 806, 825, 908, 914, 915, 916, 917, 920, 936, 966, 967, 970, 973, 974, 975, 976, 978, 981, 992, 1013, 1085, 1093, 1144, 1150, 1147, 1152, 1151, 1148, 1155, 1158, $1159,1161,1165,1166,1170,1175,1185$, $1202,1203,1228,1230,1238,1265,1276$, 1277, 1279, 1317, 1324, 1323, 1328, 1330, 1331, 1341, 1368, 1371, 1374, 1376, 1380, 1384, 1396, 1398, 1403, 1404, 1411, 1412, $1413,1414,1416,1421,1424,1427,1428$, $1439,1451,1456,1461,1462,1463,1467$, $1468,1471,1472,1473,1477,1480,1481$, 1484, 1485, 1486, 1487, 1488, 1490, 1491, 1492, 1493, 1497, 1499, 1503, 1505, 1507, $1512,1514,1515,1517,1518,1519,1522$, $1525,1526,1531,1532,1534,1535,1536$, $1539,1541,1546,1547,1548,1550,1551$, $1554,1555,1559,1561,1562,1563,1565$, $1570,1573,1574,1575$

shrubs 192, 633, 1293

silage 360,1268 silviculture $138,172,203,206,209,226$, 228, 238, 334, 492, 497, 575, 698, 830, 965, 972, 1012, 1013, 1032, 1050, 1147, 1155, 1224, 1278, 1376

site characteristics $52,55,219,271,283$, 495, 494, 496, 627, 769, 942, 957, 958, 1243,1570

site preparation $2,108,469,789$

site selection 123,1380

sludge $146,498,631,1000$

softwoods 627,1456

soil 1538

soil carbon 439

soil conservation 743

soil loss 1554

soil properties $21,92,194,193,212,214$, 318, 319, 320, 376, 452, 481, 611, 675, 700, 715, 791, 801, 889, 988, 1014, 1167, 1229, 1232, 1234, 1237, 1239, 1241, 1254, 1393, $1528,1554,1575$

soil resource inventory 1498

soil respiration 704

soil stability 1237

soil types $150,367,926,1047,1392,1425$

soil warming 224

soil water content 1260

soils $60,61,123,237,320,327,336,337$, 340, 440, 441, 459, 512, 545, 617, 689, 892, 893, 895, 896, 897, 910, 957, 958, 1052,

$1114,1220,1233,1235,1238,1298,1379$, 1389, 1496

somaclonal variations $419,672,775,777$, 781, 782, 783, 811, 815, 851, 870, 878, 879, 1274

somatic cells 775

somatic embryogenesis 408,856

somatic variations 863,879

sorghum 146, 329, 435, 892, 893, 1124,

1265, 1272, 1298, 1389

Sorghum bicolor 543

South 989

South Carolina 489

Southeast 964,1148

Southwest 1071

soybeans 330

species mixtures 203

species selection $16,17,83,123,177,179$, 180, 181, 182, 185, 184, 248, 252, 287, 334, 429, 479, 522, 633, 895, 897, 926, 967, 965, 970, 973, 974, 975, 976, 978, 981, 1039, 1043, 1049, 1055, 1099, 1146, 1164, 1263. 
1262, 1267, 1288, 1332, 1380, 1383, 1406, 1407, 1411, 1425

specific gravity $134,135,136,248,663$, 666, 929, 969

specific leaf weight 1214

spider mites 1127

sprouting $23,493,523,1185,1455$

spruces 1031,1273

squirrels 127

stakeholders 905

stand density $100,138,201,202,204$,

205, 218, 362, 360, 519, 645, 730, 734, 813, $1051,1125,1153,1288,1570$

stand dynamics 203, 571

starch 295, 411, 415, 1251, 1252

stem cankers 866,1342

stems 176, 201, 485, 648, 1057, 1365

sterility, sexual 93

stock plants 932

stocking 176, 204

stomata $23,47,112,280,530,533,534$, $689,773,812,888,885,887,889,924$,

$1102,1103,1101,1104,1440$

storage $18,35,296,681,913,916,935$,

$1008,1075,1175,1381,1547$

stratification 955

streptomyces 1558

stress 308, 428, 535, 562, 591, 1029, 1086, $1273,1363,1369,1370$

structural characteristics 1088

stump height 493,1185

succession 1301

sucrose 1251

sugar content 295

sugarcane 1124

sulfur 787

superphosphate 903

surface mines 1065

survival 1308

survival rate $367,458,648,823,924$,

1450

sustainability 390,1278

sustainable forestry 1404

sward components 998

Sweden 556

sweetgum 19, 47, 134, 224, 674, 700, 717, 734, 1093, 1134, 1197, 1358

switchgrass $11,12,13,81,83,86,92,146$, 148, 147, 157, 187, 188, 223, 222, 257, 267 , 272, 273, 285, 286, 291, 354, 353, 379, 384, 385, 388, 391, 394, 398, 400, 401, 405, 404,
$406,407,408,435,538,547,548,549,550$, $569,570,616,632,656,678,679,699,701$, 704, 707, 705, 706, 720, 726, 727, 728, 729, 735, 740, 742, 741, 745, 747, 746, 791, 795, 796, 852, 855, 894, 896, 898, 899, 900, 901, 902, 997, 998, 999, 1000, 1001, 1002, 1010, 1073, 1075, 1076, 1077, 1078, 1079, 1080, $1081,1082,1083,1084,1121,1123,1125$, 1131, 1198, 1199, 1207, 1206, 1208, 1209, $1225,1238,1265,1272,1295,1306,1307$, 1308, 1309, 1310, 1324, 1323, 1381, 1388, 1441, 1464, 1466, 1475, 1482, 1502, 1511, $1516,1521,1528,1533,1538,1540,1542$, $1544,1556,1557,1571$

sycamore 1465,1506

sycamores $19,175,224,237,362,608$, 664, 666, 1093, 1105, 1107, 1150, 1153, $1243,1254,1256,1255,1347,1348,1384$, 1480

sylleptic branching 201, 1024, 1025

Tacamahaca 79

taxonomy $378,528,1322$

tear strength 583

temperature $318,319,555,560,985$,

1557

Texas 1076, 1082, 1379

thidiazuron 948, 949, 1068

tillage 330

timber $176,457,625$

tissue culture $11,20,22,47,89,132,157$, 183, 190, 223, 222, 410, 409, 417, 418, 420, $499,565,618,620,672,733,775,778,811$, $815,851,868,870,879,880,944,946,948$, 1067, 1068, 1069, 1132, 1135, 1136, 1137 , 1138, 1139, 1141, 1274, 1346, 1355

tomato mosaic virus 1273

toxicity 367

transformation 157,1131

transformation, mediated 437

transgene 245

transgenic $137,595,622,790,1064,1179$, 1181

translocation 1088,1544

transpiration 535,1440

transportation $44,291,388,395,913$,

916, 1268, 1547

transposable elements 174

tree architecture 1434, 1436, 1438

tree growth 1524

tree improvement $7,226,876,877,951$, 952, 1135, 1137 
tree quality 513

trees, dicotyledonous 89

trees, dioecious 14,1115

tremulacin 683

triploidy 76

triterpenoids 1119

tritiated water 464

tropical forestry 203

tropical zone 1452

turgor 534

United States 388

vacuum airlift segregation 818,927

vapor pressure deficit 887

vegetation, herbaceous $611,1030,1309$

vegetation, old-field 612

Venturia populina 848

viruses $110,882,1273$

volume tables 136

walnuts, black 1391

Washington 511

waste heat 1143

wastes $43,178,616,670,905,971,1150$

wastewater $224,673,677,1143,1144$,

1145

water availability $\quad 545,936,939,1010$

water potential $306,886,1103,1101$, $1104,1260,1500$

water quality $1229,1234,1235,1237$

water relations $23,48,49,232,532,533$,

$535,690,765,889,1059,1247,1249,1261$

water storage 1440

water stress $99,731,889,1086,1250$,

1257, 1258, 1261, 1549

water tupelo 134

water yield 920

waterlogged soils $545,957,958$

waterlogging 545

water-use efficiency 274

weed control $1,314,472,474,475,643$,

$738,824,825,977,1006,1014,1369,1370$

weeds $2,565,820,828$

weight tables $134,135,136$

wetlands $177,180,181,341,380,673$

wheat 328,330

whole-tree $559,583,603,604,801,914$,

927, 1008, 1353, 1352, 1354, 1445

wildlife $312,685,1093,1235$

willows 1569

willows $3,5,7,14,19,39,41,130,317$,

349,362 , 385, 391, 394, 398, 556, 630, 644,

646, 647, 650, 651, 682, 686, 866, 1032,
$1066,1183,1214,1215,1216,1217,1218$, $1315,1316,1359,1360,1361$

willows, hybrid 1323

Wisconsin 469, 585, 589, 828, 1448

wood $18,209,218,339,363,459,574$,

583, 630, 1150, 1283, 1284, 1337, 1340,

1361

wood biomass 161, 505, 964, 1032, 1183

wood production 567

wood residues 1547

woodgrass 202

woody crops $99,146,183,200,257,333$,

334, 346, 347, 351, 366, 423, 442, 533, 655, 775, 810, 941, 949, 961, 965, 969, 1038, 1039, 1040, 1049, 1133, 1231, 1233, 1369, 1370, 1367, 1401, 1403, 1406, 1407, 1457

wounding 189

wound-responsive 74,75

xylose 122

yields 1478

yields $38,41,81,114,138,146,158,168$, 170, 201, 204, 205, 250, 252, 283, 284, 291, $320,343,363,361,433,454,458,453,465$, 523, 629, 697, 720, 730, 760, 926, 957, 958, $1051,1121,1122,1123,1124,1166,1187$, 1208, 1221, 1222, 1263, 1395, 1413, 1425

Yunnan Province, China 912

zinc 139 



\section{INTERNAL DISTRIBUTION}

1. P. A. Anderson

2. M. A. Brown

3. L. S. Cooper

4. J. H. Cushman

5. M. E. Downing

6. R. L. Graham

7. S. G. Hildebrand

8. L. A. Kszos, 1059

9. S. B. McLaughlin

\author{
10. R. D. Perlack \\ 11. V. R. Tolbert \\ 12. G. A. Tuskan \\ 13. M. E. Walsh \\ 14-22. L. L. Wright \\ 23-24. ESD Library \\ 25. ORNL Central Research Library \\ 26. ORNL Laboratory Records - RC
}

\section{EXTERNAL DISTRIBUTION}

27. R. Costello, U.S. Department of Energy, Office of the Biomass Program, Forrestal, 1000 Independence Avenue, SW, EE-2E, Washington, DC 20585

28. D. Erbach, USDA-ARS, 5601 Sunnyside Avenue, Room 4-2234, Beltsville, Maryland 20705-5139

29. J. Ferrell, U.S. Department of Energy, Office of the Biomass Program, Forrestal, 1000 Independence Avenue, SW, EE-2E, Washington, DC 20585

30. M. Jawson, USDA ARS, 5601 Sunnyside Avenue, Room 4-2264, Beltsville, MD 20705-5140

31. D. Kaempf, U.S. Department of Energy, Office of the Biomass Program, Forrestal, 1000 Independence Avenue, SW, EE-2E, Washington, DC 20585

32. G. Santos-Leon, U.S. Department of Energy, Office of the Biomass Program, Forrestal, 1000 Independence Avenue, SW, EE-2E, Washington, DC 20585

33. S. N. G. Tagore, U.S. Department of Energy, Office of the Biomass Program, Forrestal, 1000 Independence Avenue, SW, EE-2E, Washington, DC 20585 